\title{
DO LADO DE FORA DA ESCOLA ESPECIAL: HISTÓRIAS VIVIDAS NO BAIRRO E CONTADAS POR EX-ALUNOS POR MEIO DO VÍDEO
}

Tese apresentada ao Instituto de Psicologia da Universidade de São Paulo, como parte dos requisitos para obtenção do título de Doutor em Psicologia

Área de concentração: Psicologia Escolar e do Desenvolvimento Humano

Orientadora: Profa. Dra. Maria Júlia Kóvacs

São Paulo 2005 
Ficha Catalográfica preparada pelo Serviço de Biblioteca e Documentação do Instituto de Psicologia da USP

Kohatsu, L. N

Do lado de fora da escola especial: histórias vividas no bairro e contadas por ex-alunos por meio de vídeo / Lineu Norio Kohatsu. - São Paulo: s.n., 2005. - 291p.

Tese (doutorado) - Instituto de Psicologia da Universidade de São Paulo. Departamento de Psicologia da Aprendizagem, do Desenvolvimento e da Personalidade.

Orientadora: Maria Júlia Kóvacs.

1. Retardo mental 2. Inclusão social 3. Escola especial 4. Experiências de vida 5. Memória I. Título. 


\section{DO LADO DE FORA DA ESCOLA ESPECIAL: HISTÓRIAS VIVIDAS E CONTADAS POR EX-ALUNOS POR MEIO DO VÍDEO}

LINEU NORIO KOHATSU

\section{BANCA EXAMINADORA}

(Nome e Assinatura)

(Nome e Assinatura)

(Nome e Assinatura)

(Nome e Assinatura)

(Nome e Assinatura)

Tese defendida e aprovada em

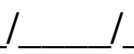


À querida Lígia (in memorian) Aos meus pais 


\section{Agradecimentos}

À querida mestra Lígia Assumpção Amaral, cuja sabedoria nos faz tanta falta e que nos deixa profundas saudades...

À Profa. Dra. Maria Júlia Kóvacs pelo acolhimento, pela orientação e por acreditar que conseguiríamos chegar ao final, muito obrigado;

Às Professoras Maria Luisa Schimdt e Maria Eloísa Famá D’Antino pelas preciosas contribuições dadas por ocasião do exame de qualificação, pelo incentivo e pelo apoio.

À Luzia, Mário e Márcio por compartilharem comigo as suas histórias tão valiosas.

A Sra. Floriza e o Sr. Matteo pela confiança que me foi dada.

A todos aqueles que partilharam das histórias e que generosamente cederam seus depoimentos.

Aos colegas e alunos da educação especial com quem pude aprender tanto, vocês fazem parte da minha história.

Aos fraternos companheiros e companheiras, orientandos da Profa. Lígia e da Profa. Maria Júlia, aos de ontem, aos de hoje, a todos.

Aos grandes amigos de sempre, Robson, Sônia, Glauco, Sinésio, Sérgio e Osmar.

À querida Márcia que se encontra tão longe e tão perto e à Paula, cuja amizade o tempo não enfraquece.

Ao Marcel e ao Paulo pelas histórias de tantos anos.

Ao Fábio, Dilu e Renata, my friends.

À Vera Vassalo pela ajuda em fechar mais uma gestalt.

Aos meus queridos meus pais, por tudo que me ensinam até hoje com tanto amor.

À saudosa Dona Beth, pelas suas fantásticas e memoráveis histórias e por ter dado tanto amor à sua neta.

À minha querida esposa Elisa, pelo apoio, pela compreensão e por esperar, pacientemente, por todo esse longo tempo.

Às minhas queridas e lindas filhas,Fernanda e Beatriz, pela ternura. 


\section{Sumário}

Resumo . . . . . . . . . . . . . . . . . . . . ix

Abstract . . . . . . . . . . . . . . . . . . . . $\mathrm{x}$

Apresentação . . . . . . . . . . . . . . . . . . . .

\section{NTRODUÇÃO}

- 0 relato de uma experiência acadêmica . . . . . . . . . 01

- Escadarias: fotografias da periferia realizadas por jovens com deficiência mental. . . . . . . . . . . . 02

-...Olhares da periferia. . . . . . . . . . . . . . . . 06

- 0 relato de uma experiência profissional. . . . . . . . . . 09

- Conhecendo a cidade na companhia dos alunos. . . . 09

口 Problematização. . . . . . . . . . . . . . . . 19

- A escolha do vídeo. . . . . . . . . . . . . 20

- A escolha dos participantes. . . . . . . . . . . 20

- Por que sobre o bairro onde moram? . . . . . . . 22

- Retomando o fio da meada: a síntese da proposta . . . . . 27

\section{CAPÍTULO I}

OLHANDO PARA O LADO DE DENTRO: A ESCOLA. . . . . . . 30

- Lembranças da escola primária.. . . . . . . . . . . . . 31

- Da realidade para a ficção: refletindo sobre a experiência vivida. 39

- O ingresso no universo desconhecido. . . . . . . . . 40

- Colorindo a paisagem: a criação dos vínculos afetivos. . 45

- As vivências amargas. . . . . . . . . . . . . . . 45

- Dando um giro na espiral: reflexões sobre as experiências. . . 59

\section{CAPÍTULO II}

\section{OLHANDO PARA O BAIRRO}

- Olhando do lado de fora do muro: o bairro e a cidade . . . . 62

- A saudosa Vila Beatriz. . . . . . . . . . . . . . 64

- O olho e o espírito" do viajante . . . . . . . . . . . . 71

- Das vilas ao ABC: experiências de uma passagem . . . . . 76

- 0 olhar que interroga: algumas questões sobre a cidade . . . 77 


\section{CAPÍTULO III}

\section{A PESQUISA}

\section{Parte I - Sobre o método}

- Algumas reflexões sobre o método. . . . . . . . . . . 80

- Em busca de referenciais teórico-metodológicos para pensar sobre o método. . . . . . . . . . . . . . . . . 84

- A abordagem qualitativa . . . . . . . . . . . . . 85

- A pesquisa de tipo etnográfico . . . . . . . . . . . . . . . 91

- As imagens visuais na pesquisa etnográfica . . . . . . . 93

- Algumas considerações acerca da utilização de imagens na pesquisa . . . . . . . . . . . . . . . . . . . 95

口 Considerações sobre o vídeo. . . . . . . . . . . . . . . 99

\section{Parte II - Sobre a pesquisa}

1. Objetivos da pesquisa. . . . . . . . . . . . . . . 102

2. Participantes. . . . . . . . . . . . . . . . . 103

3. Local da pesquisa . . . . . . . . . . . . . . . . 103

4. A proposta . . . . . . . . . . . . . . . . . 103

5. Procedimentos/etapas. . . . . . . . . . . . . . 104

6. Organização e reflexão sobre material coletado . . . . . . 104

6.1. Organização dos materiais . . . . . . . . . . . 105

\section{CAPÍTULO IV}

APRESENTAÇÃO DAS EXPERIÊNCIAS. . . . . . . . . . . . 106

\section{LUZIA}

\section{Primeira Parte}

Conhecendo o Boa Vista em companhia de Luzia.

Segunda Parte

Trabalho de compreensão, discussão e reflexão acerca do material produzido

a. O bairro como espaço vivido . . . . . . . . . . . . 116

- Sobre os assuntos gravados. . . . . . . . . . . 117

- A favela e a periferia como espaços de vivências

compartilhadas: a vida comunitária, os amigos e vizinhos. 123

b. O tempo vivido no bairro

- A lembrança dos velhos tempos: uma ponte entre o passado, o presente e o futuro. . . . . . . . . . . . 129 


\section{MÁRIO}

\section{Primeira Parte}

\section{Conhecendo a Vila Rosa em companhia de Mário}

- Relatos dos encontros ou... A caminhada pela Vila Rosa . . . 135

\section{Segunda parte}

\section{Trabalho de compreensão, discussão e reflexão acerca do} material produzido

a. O bairro como espaço vivido

- A Vila Rosa . . . . . . . . . . . . . . . 154

- Desvelando a constelação social de Mário .. . . . . . 160

b. O tempo vivido no bairro: um mergulho no tempo, nas histórias e lembranças narradas por Mário e alguns moradores

- A Vila Rosa ontem. . . . . . . . . . 171

- Lembranças da história de Mário. . . . . . . . . 175

- Do passado ao presente . . . . . . . . . . . . . . . 181

\section{MÁRCIO}

\section{Primeira Parte}

\section{Conhecendo o J ardim das Orquídeas em companhia de Márcio}

- Alguns anos atrás .

- Relato dos encontros ou... Os passos pelo Jardim das Orquídeas.

\section{Segunda Parte}

\section{Trabalho de compreensão, discussão e reflexão acerca do} material produzido

a. O bairro como espaço vivido.

- Desvendando o lado de dentro: a casa . . . . . . 202

- Desbravando o lado de fora: os lugares do bairro . . . 207

b. O tempo vivido no bairro: um mergulho no tempo, nas histórias e lembranças narradas por alguns moradores. . . . 214

- Era uma vez no Jardim das Orquídeas . . . . . . . . 214

- A história da família de Márcio . . . . . . . . . . . . 214

- Revisitando a infância de Márcio. . . . . . . . . . . . 218

- Das histórias do bairro para as histórias da escola. . . . 222

- Depois da escola especial, o retorno ao bairro. . . . . . 223 


\section{Terceira parte}

a. O bairro como espaço vivido. . . . . . . . . . . . . . 228

- A quadra . . . . . . . . . . . . . . . 230

- A igreja como lugar de encontro. . . . . . . . . . . 235

- Uma reflexão sobre a convivência social no bairro . . . 236

- Sobre barreiras e limites: três obstáculos a serem superados . . . . . . . . . . . . . . . 239

1. Sobre a leitura e compreensão da deficiência como possível barreira .. . . . . . . . . . . . 240

2. A família como barreira. . . . . . . . . . . . 243

3. A escola especial como barreira . . . . . . . . . . 244

- Retornando à difícil relação entre família e escola . . . 247

- Resgatando a responsabilidade da escola especial. . . . . 248

- Desmanchando muros e construindo pontes para a inclusão sócial . . . . . . . . . . . . . . 252

b. Uma reflexão sobre o tempo vivido. . . . . . . . . . . 257

- A história reconstruída com os outros: encontros e desencontros. . . . . . . . . . . . . 260

- A memória compartilhada e a inclusão social . . . . 262

\section{Reflexões sobre algumas possíveis contribuições da pesquisa}

- Da parte que cabe aos participantes . . . . . . . . . . 270

- Considerações sobre as contribuições ao campo científico. . . 274

- Sobre os lugares ocupados pelo vídeo na pesquisa . . . . . . 278

- Considerações sobre as contribuições ao campo educacionaL. 279

CONSI DERAÇÕES FI NAIS. . . . . . . . . . . . . . . . . . . 282

REFERÊNCI AS BI BLIOGRÁFICAS . . . . . . . . . . . . . 286

\section{Anexos}




\section{RESUMO}

Kohatsu, Lineu Norio. Do lado de fora da escola especial: histórias vividas no bairro e contadas por ex-alunos por meio do vídeo. São Paulo, 2005, 291p. Tese (Doutorado). Instituto de Psicologia. Universidade de São Paulo.

0 presente trabalho tem como objetivo principal o conhecimento e a compreensão da relação que ex-alunos de escolas especiais mantêm com os seus bairros. Para a realização do estudo, foi proposta a produção de um vídeo aos participantes, tendo também como objetivo secundário uma reflexão sobre esse processo. A investigação parte de cinco perguntas norteadoras: 1) Como se constituiu o universo social dessas pessoas (ex-alunos de uma escola especial) para além dos muros institucionais da escola? 2) Será que a permanência na escola especial dificultou ao aluno 0 conhecimento de seu bairro e será que a saída da escola proporcionou essa aproximação? 3) Como vivenciaram e ocuparam o espaço do bairro? Quais foram as experiências mais significativas? Em que período da vida ocorreram? 4) Como é para essas pessoas morar na periferia? Será que o contexto comunitário (se existente) favoreceu de algum modo a sua socialização? 5) Em que medida o vídeo auxiliou no conhecimento da realidade vivida pelo participante da pesquisa? 0 estudo se caracteriza como uma pesquisa qualitativa, de orientação fenomenológica, tendo a pesquisa de tipo etnográfica como referência metodológica e a utilização do vídeo como recurso. Participaram da pesquisa 03 ex-alunos de escola especial: uma do sexo feminino, 23 anos, funcionária de uma empresa de limpeza, e dois do sexo masculino com 24 e 41 anos, ambos trabalhadores de uma oficina abrigada. Foram utilizados como critério de escolha dos participantes a independência na locomoção, que morassem desde criança no bairro e que demonstrassem interesse na participação da pesquisa. A pesquisa ocorreu em três bairros do Município de São Bernardo do Campo: a favela Boa Vista, a Vila Rosa e o Jardim das Orquídeas, esta última situada numa zona de manancial. As gravações dos bairros foram realizadas individualmente: a primeira experiência (piloto) ocorreu em um único encontro, com uma gravação de quinze minutos; a segunda ocorreu em cinco encontros e aproximadamente 60 minutos de gravação; a terceira e última foi realizada em seis encontros e aproximadamente 90 minutos de gravação. A organização do material composta pelas gravações em vídeo, áudio e anotações de campo ocorreu da seguinte forma: transcrição dos materiais (vídeo e áudio), observação das gravações em vídeo, apontamento das cenas/locais gravados e levantamento de temas. A discussão sobre os trabalhos foi feita primeiramente de modo individual e no final foi realizada uma discussão conjunta dos três trabalhos. 0 que se pode perceber é que cada um dos três participantes apresenta um modo bastante particular de se relacionar com o bairro e com diferentes níveis de integração. Observa-se também que, mesmo após saírem da escola especial, os três participantes mantêm vínculos com pessoas relacionadas a esse universo social. Pode-se perceber também que o contato com os espaços do bairro possibilitou a eles recordações de eventos da infância, assim como as conversas com os vizinhos proporcionaram a revitalização das memórias do passado. 0 estudo mostra, desse modo, como as pessoas com deficiência mental podem reconstruir as próprias histórias e podem participar da construção da memória coletiva de seus respectivos bairros.

\section{Palavras-chave: retardo mental, inclusão social, experiências de vida, Escola especial, memória.}




\begin{abstract}
Kohatsu, Lineu Norio. Outside Special School: histories lived in the neighbourhood and told by former students by means of video films. São Paulo, 2005, 291p. Thesis (Doctorship). Instituto de Psicologia. Universidade de São Paulo.
\end{abstract}

The main objective of the present work is the knowledge and comprehension of the relationship maintained by former students of Special Schools with their neighbourhood. In order to do so, the production of a vídeo was suggested to the participants, with the secondary objective of a reflection about this process. The investigation starts with 5 driving questions: 1) How was the social universe of these people (former students of a Special School) constituted beyond the institutional walls of the school? 2) Has their permanence at a Special School made it difficult for them to know their neighbourhood and their exit made this approach possible? 3) How have they lived and occupied the spaces in their neighbourhood? What were the most significative experiences? Which period of their life did they happen? 4) What is living in the suburbs like for these people? Did the communitary environment (if there is any) somehow favoured their socialization? 5) To what extend has the video filming given support to the knowledge of the reality lived by the participant of this research? This study is characterized by a Qualitative Research, with Phenomenological Approach, having the Etnographic type of research as a methodological reference and the use of video as a mean of investigation. Three (3) former students of Special Schools took part in this research: one female, 23 y.o., who works at a cleaning company; and 2 male, 24 and 41 y.0., both workers at a "shelter workshop" (professional training and job for disabled). For their selection, the criteria were their independence to move, their living in the neighbourhood since childhood and having showed interest to take part in the research. The survey took place in three districts of São Bernardo do Campo City: Boa Vista, Vila Rosa and Jardim das Orquídeas Slums, this latter placed in a fountainhead reserve (Billings Reservoir). The recordings of the neighbourhood occurred individually: the first experience (pilot) happened in just one meeting, with a recording lasting 15 minutes; the second occurred in 5 meetings and lasted about 60 minutes; the third and last happened in 6 meetings and lasted about 90 minutes. The organization of the material composed by video and audio recordings and field notes was made as follows: material transcriptions (video and audio), observation of the video films and notes about the scenes / places recorded and, at last, the raising of themes. The discussion about the works was made at first individually and in the end there was a discussion about the three works altogether. We may notice that every participant presents a very particular way to relate with his neighbourhood and that there are different levels of integration. We may observe also that, even after leaving Special Schools, the three participants kept connections with the people referred in their social universe. We still may notice that the contact with the places in the neighbourhood has favoured their remembering events from childhood, as well as their conversations with neighbours have favoured the revival of memories from the past. Thus, the study shows how the people with mental deficiency may rebuild their own histories and participate in the construction of the collective memory of their neighbourhoods.

\title{
Key-words: mental retard, social inclusion, life experience, Special School, memory.
}




\section{APRESENTAÇÃO}

Começar é sempre difícil. Tão difícil quanto terminar. Começarei dizendo que se trata de um estudo, uma pesquisa sobre histórias: histórias vividas e contadas por ex-alunos de escola especial, histórias vividas e contadas por mim sobre a escola, o bairro e também histórias de ficção algumas, porém, muito reais.

Esta pesquisa propõe uma reflexão sobre o vivido de hoje e também sobre o vivido de ontem, ou seja, sobre a memória. Fala de experiências de vida diferentes, mas que podem ser compartilhadas apesar da distância no tempo e no espaço; fala sobre a possibilidade do encontro entre as pessoas e sobre a possibilidade de comunicação apesar das barreiras econômicas, sociais, culturais, dos preconceitos, dos estigmas...

Cada nova etapa, como esta pesquisa de doutorado, é, de certa forma, uma síntese de uma trajetória vivida. No meu caso, meu percurso vem sendo trilhado na interface da educação com a psicologia entre outras tantas como a fotografia, o vídeo etc.

Tenho aprendido muito com as pessoas que venho encontrando nesse caminhar, não somente pelo mundo acadêmico, mas também profissional e, sobretudo, pela vida.

A minha trajetória profissional é bastante diversificada, com experiências bem diferentes umas das outras, mas poderia dizer que todas muito intensas e marcantes. Como poderia me esquecer da primeira escola especial em que trabalhei, quando ainda cursava somente o primeiro ano do curso de psicologia? E da experiência na Penitenciária do Estado? Éramos um grupo pioneiro, formado por universitários idealistas que brigavam pela reabertura da escola em 1989, após esta ter permanecido fechada por muitos anos. Não só trabalhávamos dando aulas de alfabetização aos que se encontravam presos, mas também estudávamos, líamos e debatíamos muito, principalmente as idéias de Paulo Freire, buscando incessantemente encontrar meios para fundamentar a nossa prática que se mostrava tão contraditória, afinal, como podíamos falar de uma educação libertadora em um local como a prisão que limita ao máximo a expressão da liberdade? 
Mas, se não encontramos uma resposta, certamente, aprendemos que a busca também nunca termina.

Além da educação de adultos, a educação especial também contribuiu em minha formação profissional, acadêmica e pessoal. Trabalhei como psicólogo em duas escolas especiais, em dois períodos distintos. Nesse ínterim, ingressei no curso de pós-graduação em Distúrbios do Desenvolvimento, na Universidade Mackenzie. Foi nessa ocasião que eu conheci a querida e saudosa Professora Lígia Assumpção Amaral.

Conheci a Lígia na década de noventa, há quase dez anos. Como o tempo voa. Lígia foi minha professora no curso de pós-graduação. Não me recordo exatamente o ano, talvez 1994, mas não fazia muito tempo que eu havia me formado.

Em sua disciplina, Lígia discutia questões sobre a deficiência, sobre o preconceito, sobre a discriminação, mas ela buscava situar a discussão no âmbito da vida, das relações de carne e osso, como ela mesma dizia. Lembro-me que, em uma de suas aulas iniciais, perguntei-lhe ingenuamente qual era a sua referência teórica! O leitor poderia se perguntar, mas qual é o problema de se querer saber sobre a referência teórica, afinal isto é esperado no meio acadêmico, principalmente num curso de pós-graduação. A questão é que, o que estava em pauta não era a teoria, mas vida. 0 que a Lígia queria nos mostrar era a necessidade de transcendermos a discussão estritamente intelectual e nos colocarmos inteiros, de corpo e alma, na compreensão do que é o humano, pois é nessa dimensão que ela situava a deficiência.

Alguns anos mais tarde, quando eu era seu orientando de mestrado e pensava já ter me esquecido do acontecimento, Lígia escreve em sua carta a famosa carta que ela escrevia a todos os seus orientandos, ao final de cada jornada de mestrado ou doutorado - recordando desse evento:

Por falar em risos e sorrisos, lembra de nosso primeiro contato? Pois bem, fosse qual fosse o "embasamento teórico" em jogo, afinal, nossa convivência não se baseou nele! Que bom! Assim, pudemos construir uma relação de 
carne e osso - e estou plenamente convencida que esse é o mais fértil e prazeroso dos relacionamentos humanos.

Hoje, compartilho plenamente de sua sabedoria. E, como ela mesma escreveu, nossa convivência não se limitou ao "embasamento teórico". E por esse motivo, quem sabe, pude compartilhar de outros momentos tão preciosos, tão sábios. Não somente eu, mas toda a "confraria" formada pelos seus orientandos.

Concluído o mestrado, fui novamente seu orientando no doutorado, mas, infelizmente, não pudemos concluir mais este ciclo juntos devido ao seu falecimento. Mas recordo-me das conversas que tivemos sobre o projeto ainda pouco definido; lembro-me principalmente de nossa última conversa, há poucos dias antes de seu falecimento. Lembro-me claramente que estávamos em sua sala e pela janela eu podia avistar o início do anoitecer de uma tarde de inverno. Lembro-me como ela me incentivou ao trabalho de campo nessa pesquisa em um momento em que quase desistia do projeto diante de tantas dificuldades.

Lígia era uma pessoa que sempre nos encorajava em nossas travessias, por mais difíceis que fossem para nós. Se preciso, pegava em nossa mão e nos acompanhava até chegarmos ao outro lado, na margem, ou até que pudéssemos caminhar sozinhos.

Agora, cada um de nós que foi seu aluno, seu orientando ou ouvinte, que pode compartilhar de sua sabedoria, de seu afeto, carrega um pouco dessas experiências vividas na companhia da mestra. Agora, resta a nós manter viva a chama da memória.

Vejo que muito do que penso e do que escrevo contém uma dose de seu conhecimento. Nesta pesquisa, certamente há muito do que pude aprender com ela. Não somente nas linhas em que se encontram as citações, mas, talvez e, principalmente, nas entrelinhas. E, assim, espero poder compartilhar com o leitor um pouco do tanto que aprendi com a Lígia. 


\section{Introdução}

As origens do projeto de pesquisa

Pretendo nesta introdução compartilhar com o leitor o caminho até então percorrido para elaboração deste projeto de pesquisa para que, posteriormente, possa situar-se melhor na problematização.

São três pontos de partida de naturezas distintas: uma é pessoal, uma é acadêmica, e a última é profissional. De certa maneira, referem-se a algumas de minhas memórias, experiências e reflexões.

A parte pessoal refere-se às lembranças que trago da escola e também sobre a minha relação com 0 bairro onde passei a infância e juventude. Não deixo de falar também do olhar do viajante que foi se constituindo a partir das minhas experiências de viagem e que me proporcionaram um outro olhar sobre o meu cotidiano; olhar que, sem dúvida, também me impulsiona e me acompanha nesta pesquisa/viagem.

0 segundo ponto refere-se a uma experiência acadêmica. Trata-se de um trabalho apresentado em um congresso (Kohatsu, 1999b), mais especificamente a Reunião Anual da SBPC, em que discuto o trabalho fotográfico de dois jovens, alunos de uma escola especial, cujo tema foi a favela onde moravam. Retomo esse trabalho pela importância que ele teve ao revelar, de certo modo, o olhar e a relação que os jovens mantinham com o bairro em que viviam.

0 terceiro e último ponto é de caráter profissional. Refere-se à minha experiência como psicólogo de escola especial, quando realizei, com mais duas professoras, um treino de locomoção junto a seus respectivos alunos e tive a oportunidade de conhecer um pouco dos bairros onde moravam. 
Nessa experiência foi possível vivenciar também uma outra relação com os alunos, diferente daquela que costumeiramente mantínhamos dentro da escola, conhecendo outras facetas interessantes que somente se revelaram durante nossas viagens pelos caminhos de São Bernardo do Campo.

Nesta introdução relatarei somente o segundo e terceiro pontos, referentes à experiência acadêmica e profissional. A parte relativa às minhas memórias da escola e do bairro serão apresentadas nos capítulos iniciais.

\section{O RELATO DE UMA EXPERI ÊNCI A ACADÊMI CA}

\section{Escadarias: fotografias da periferia realizadas por jovens com deficiência mental}

Em 1999 apresentei um pôster na Reunião Anual da SBPC (Sociedade Brasileira para o Progresso da Ciência) com o título acima indicado (Kohatsu, 1999b). Esse trabalho teve origem na disciplina Estética Comparada, ministrada pela Profa. Elza Ajzenberg, na Escola de Comunicações e Artes da USP. A disciplina foi cursada durante o período em que ainda realizava a pesquisa de mestrado, da qual aproveitei alguns dados para elaboração do referido trabalho, sintetizado posteriormente na forma de pôster para apresentação no congresso.

A pesquisa (Kohatsu, 1999a), por sua vez, tinha como objetivo estudar a expressão fotográfica de alunos e ex-alunos de uma escola especial para deficientes mentais. Os dados foram coletados durante a realização de uma oficina de fotografia oferecida a 10 jovens, entre alunos e ex-alunos de uma escola especial, de ambos os sexos e com faixa etária entre 14 e 22 anos. Durante a oficina, realizada em 1998 e com duração de 04 meses, os participantes puderam fotografar temas de livre escolha. Os encontros ocorreram duas vezes por semana, com duração aproximada de uma hora e meia. Neste período os participantes relatavam o que haviam fotografado, as intenções, as dificuldades, enfim, o processo ocorrido. Com 
relação ao funcionamento da oficina, é importante ressaltar que as fotografias foram realizadas pelos próprios participantes, nos locais determinados por eles, sendo os temas escolhidos conforme 0 interesse de cada pessoa, não desconsiderando, no entanto, a hipótese de que as trocas com os colegas possam ter sugerido a realização de temas em comum. Para que esse trabalho pudesse ser realizado dessa maneira, no início da oficina foi emprestada uma câmera fotográfica ${ }^{1}$ a cada participante, ficando esta sob sua responsabilidade até o final. Cada participante recebia um filme por vez, levando em média duas semanas para realização das fotos. Concluído o filme, este era entregue a mim para que eu providenciasse a revelação em laboratório comercial. As fotos, após serem reveladas, eram retornadas aos seus respectivos realizadores, comentadas durante as sessões e depois ficavam definitivamente em posse deles. Com relação aos negativos, estes ficaram comigo e deles foram feitas cópias-contato para servirem como material de registro. Durante esse período foram produzidas aproximadamente duas mil fotos pelo grupo.

\section{Por que fotografias de escadarias?}

Como foi relatada anteriormente, a idéia de se elaborar o trabalho surgiu em decorrência de uma exigência da disciplina Estética Comparada, cuja proposta era a de que os alunos apresentassem seminários a partir de dois grandes temas: Arte-Cidade ou Arte-Ciência. Esses seminários posteriormente deveriam ser redigidos e apresentados como trabalhos de final de curso. Escolhi trabalhar com o tema Arte-Cidade por entender que estaria mais próximo de minha pesquisa do mestrado, embora ainda não tivesse idéia sobre o que apresentar.

Ao observar as fotos produzidas pelos participantes da Oficina pude perceber que, de certo modo, todos haviam realizado fotos nos locais onde moravam, retratando, assim, os respectivos bairros. Em virtude da grande

\footnotetext{
${ }^{1}$ Câmera de 35 mm, automática, com flash embutido, marca Charman, modelo M707.
} 
quantidade de fotos desse gênero, estabeleci como critério trabalhar somente com aquelas em que o bairro havia sido retratado como assunto principal.

Logo de início, dos trabalhos fotográficos dos dez participantes, um me chamou a atenção: as fotos de Antônio². Ele havia realizado fotos com a intenção explícita de mostrar exclusivamente a favela onde morava e, diferentemente do que ocorria na maioria das vezes com os participantes, André tinha seu objetivo previamente estabelecido.

Sua idéia surgiu em um dos encontros quando os participantes lamentavam não ter mais o que fotografar, pois nos lugares onde moravam, ou seja, bairros da periferia pobre, não existiam locais bonitos para realizarem as fotos. Contrariando seus colegas Antônio disse que na favela onde morava existiam locais bonitos e que ele iria fotografá-los. Posteriormente, elaborou melhor sua idéia e disse que em um dos filmes fotografaria apenas os lugares bonitos da favela e em outro, apenas os lugares feios.

Alguns dias depois Antônio retornou à Oficina para entregar os filmes para revelação e contou, meio decepcionado, que não havia conseguido realizar a idéia inicial, fotografando somente os lugares feios. Ele explicou que quando partiu para fotografar os lugares bonitos foi impedido pelos traficantes da favela, pois esses lugares estavam dentro da área deles. Em relação aos lugares considerados feios, curiosamente, todas as fotos são de escadarias da favela e durante o relato de sua experiência foi notável como 0 tema da violência se fez presente.

Ao rever o trabalho de Antônio e mais especificamente as fotos das escadarias de sua favela concluí que estas poderiam servir perfeitamente para realização de meu seminário, visto que haviam sido feitas com a intenção explícita de retratar o local onde vivia, podendo, desse modo, servir à proposta do tema Arte-Cidade. Todavia, apesar de apresentar perfeitamente os critérios para elaboração do trabalho, o conjunto trazia um

\footnotetext{
2 Os nomes aqui apresentados nâo são os nomes verdadeiros dos participantes.
} 
problema. As fotos das escadarias de Antônio vinham associadas explicitamente ao tema da violência. Meu receio foi o de que, ao realizar um trabalho a partir dessas fotos poderia mais uma vez reforçar a associação estigmatizada entre periferia e violência tão intensamente divulgada pela imprensa. Além disso, o tema da violência não comparecia no relato de outros participantes da Oficina que eram, também, moradores da periferia. Desse modo, apesar das fotos de Antônio servirem ao fim a que se destinavam, pensei que o meu trabalho não poderia ficar restrito a elas, visto que não representavam, a meu ver, o trabalho do grupo tal como eu gostaria. Pensei então em procurar uma outra amostra mais representativa do grupo, mas quais fotos escolher?

Retornei diversas vezes às fotos dos participantes, olhei-as inúmeras vezes com a intenção de encontrar alguma em que estivesse evidente a intenção de retratar o bairro ou que pelo menos estivesse acompanhada por algum relato em que houvesse a explicitação verbal de sua intenção, restringindo, desse modo, a arbitrariedade de minha escolha. Após uma cuidadosa observação, encontrei um conjunto de fotos em que seu autor também retratava o local onde morava. Procurei retomar os comentários que ele havia feito sobre as fotos e percebi que neles compareciam com freqüência relatos sobre o local. Além disso, no momento em que Clóvis, o fotógrafo, deu os títulos para as suas fotos, procedimento usual na Oficina, o local foi novamente destacado: "A beleza da minha viela", "A viela da minha vila", "A bananeira da minha vila". Ao juntar essas informações não tive mais dúvidas de que suas fotos também serviam perfeitamente para o meu trabalho.

Um fato curioso, do qual somente me dei conta posteriormente, é que o local das fotos de Clóvis era uma escadaria, embora ele se referisse a ela como uma viela. Foi somente nesse momento que percebi, com espanto, a curiosa coincidência: tanto Antônio quanto Clóvis haviam escolhido as escadarias dos respectivos bairros para fotografar, porém com significados tão diversos. A coincidência havia me deixado tão impressionado e tão 
gratificado que resolvi trabalhar esses dois conjuntos com o tema em comum: as escadarias.

\section{Olhares da periferia}

\section{As escadas vistas por Antônio}

As escadas, segundo Antônio, são como corredores: "pelas escadas você pode rodar a favela inteirinha". Ele diz ainda: "Ali o que mais tem é escada pra bandido correr". Cercadas por construções dos dois lados, essas escadas se assemelham a becos, com acesso somente pelas extremidades, pois ao longo das altas paredes laterais existem somente alguns acessos para as casas. Assim como foi dito por Antônio, as escadarias podem levar para toda a favela, mas isto não quer dizer que se possa circular livre e impunemente por todos os lugares. Desse modo, quem não conhece o lugar, além do risco de se perder, pode atravessar territórios nem sempre seguros para todos.

O sentido de território é também citado por Antônio. Ele afirmou conhecer todos os acessos, mas disse que depois de certa altura da favela não ousa cruzar a linha que separa do terreno vizinho. Antônio não deixou isso muito claro, mas o que pude entender é que existe rivalidade entre grupos de traficantes dos dois lados. Segundo suas próprias palavras, "0 negócio lá é feio".

Nas fotos das escadarias não se vêem pessoas; todas estão vazias e somente em uma delas está presente um garoto fotografado de costas que está subindo as escadas.

Para Antônio as escadas não são bonitas, pelo contrário, são "zuadas", como ele mesmo se referiu. O que dá para se entender é que Antônio considera as escadas como lugares de sujeira porque os moradores jogam lixo nelas e também porque corre muita água suja. 
De todos os lugares existentes em sua favela, Antônio elegeu as escadas como representantes daquilo que considera feio. Através do relato podemos notar as associações que ele fez a partir delas: violência, sujeira, lugar de todos e de ninguém (será que por isso não existem pessoas nas fotos?).

Ao olhar para as fotos podemos observar ainda a escuridão e vazio. 0 que podemos entender com isso? Houve alguma intenção ou foi mera coincidência? São questões que não serão respondidas e podem ser interpretadas de modos diferentes pelos leitores. Enfim, estas são as escadarias vistas por Antônio. Não expressam nem mais nem menos verdade sobre a periferia, são apenas amostras da percepção que ele tem da realidade onde vive. Apenas o que ele considera como feio, pois do bonito ficamos todos privados.

\section{A escadaria habitada por Clóvis}

Diferentemente das fotos de Antônio, a escadaria retratada por Clóvis não está vazia, pelo contrário, está plenamente habitada, ocupada de tal forma que foi difícil até saber se elas retratavam o lugar ou as pessoas. Somente muito tempo depois é que fui compreender que essa separação existia somente na minha cabeça, pois o que suas fotos mostravam era justamente o modo como as pessoas estavam integradas ao espaço - nesta paisagem, o espaço e as pessoas compõem cena única.

Há diversas fotos onde a família se utiliza do espaço da escada para posar. Contudo, em uma foto, ao contrário, sugere que as pessoas estão ali por outra finalidade (talvez descansando ou tomando sol), mas não necessariamente para a foto: estão dispersas no espaço, não estão olhando para a câmera (talvez uma das irmãs, mas pela posição não sabemos se está olhando para o garoto). Essa foto em particular chamou-me a atenção pois dá a impressão de um cotidiano possível e não somente um momento artificial para a foto. Esta imagem, segundo minha leitura, reforça a idéia de 
que o espaço público da escadaria é utilizado como uma extensão do espaço familiar privado e compartilhado com os vizinhos - ao menos indiretamente, dando-nos pistas de como esse local, situado na periferia de um município industrial, é ocupado pelos seus habitantes, segundo a ótica de um representante do próprio grupo.

Através das fotos de Clóvis podemos também levantar algumas hipóteses sobre como ocorrem as relações entre as pessoas nessa comunidade. Apesar do termo comunidade ser questionável, principalmente tendo como referência a sociedade industrial que privilegia o individualismo, é possível notar que no local onde Clóvis mora a própria forma de construção das casas (espaço privado) - com acesso direto à escadaria - favorece a comunicação com a vila (espaço público) e conseqüentemente a convivência comunitária - embora não se saiba se isso realmente ocorre. De todo modo, podemos observar através das fotos alguns indícios que vão ao encontro dessa hipótese revelando, dessa forma, uma outra perspectiva de enxergar a periferia.

\section{A partir das fotos de Antônio e Clóvis...}

0 trabalho desses dois jovens mostra aspectos diferenciados da periferia; não se nega necessariamente a existência da violência, mas revela principalmente outros aspectos que passam despercebidos pelo olhar do estrangeiro; mostra principalmente 0 que não se vê pela tevê. 0 que procurei evitar, desse modo, foi a reprodução da associação preconceituosa que constantemente é veiculada pelos meios de comunicação entre periferia e violência, ou, em outras palavras, a idéia da violência como atributo exclusivo das classes mais desfavorecidas.

A partir desse trabalho, apesar de ter sido realizado já há tanto tempo, ainda sinto-me provocado e instigado a prosseguir por este caminho. Para mim, o trabalho desses dois jovens revela não o olhar supostamente imparcial e objetivo do foto jornalismo - pois como afirma Kossoy (1989, 
1999), a fotografia é sempre uma criação - mas o testemunho de quem vive a realidade retratada, o "olhar de dentro da cultura", tal como denominaram alguns pesquisadores da Antropologia Visual (Tacca,1990).

Esse trabalho ainda me inspira e me dá a vontade de querer continuar conhecendo a realidade de outros jovens também considerados deficientes mentais, também moradores da periferia e saber de que modo olham, habitam e se relacionam com o bairro e a cidade onde vivem. Penso que, através desse trabalho, podemos nos surpreender não com os aspectos que nos diferenciam e distanciam dessas pessoas, mas pelo que elas podem nos revelar das nossas semelhanças e familiaridades, enfim, da humanidade que nos é comum apesar das diferenças.

\section{O RELATO DE UMA EXPERI ÊNCI A PROFI SSI ONAL}

\section{Conhecendo a cidade na companhia dos alunos}

Trabalhei do ano 2000 a 2004 como psicólogo em uma escola especial de um município da Grande São Paulo. Nesta escola havia uma equipe técnica, da qual fiz parte, formada por profissionais de diversas áreas: Pedagogia, Psicologia, Fonoaudiologia e do Serviço Social. O quadro de funcionários era formado, também, por professoras formadas em pedagogia e habilitação em deficiência mental, inspetoras de alunos, pessoal da limpeza, merendeiras, a diretora e os oficiais administrativos.

Nesta escola estudavam mais de duzentos alunos com deficiência mental - alguns com outras deficiências (física e sensorial) e alguns outros quadros associados - na faixa etária dos cinco aos vinte e cinco anos aproximadamente. Em relação ao nível sócio-econômico, grande parte dos alunos pertence a famílias de baixa renda que vivem em diversos pontos da cidade. Desse modo, como a grande maioria vem de bairros distantes, acaba fazendo uso do transporte escolar. Considero este dado relevante por dois 
motivos. Primeiro, porque grande parte dos alunos ao estudar fora de suas comunidades de origem, acaba se distanciando do convívio de pessoas do próprio bairro por um período significativo do dia33. Segundo, ao fazerem uso do transporte escolar muitos acabam não sendo incentivados a desenvolver a independência de locomoção, deixando de conhecer o bairro onde moram e o entorno da própria escola. Além disso, pelo fato da escola ser distante da moradia, muitos pais têm demonstrado receio em permitir que os filhos utilizem o transporte coletivo público.

Logo que ingressei na escola comecei a trabalhar junto ao programa denominado Oficinas de Trabalho, onde permaneci nos anos 2000 e 2001. 0 programa era freqüentado por adolescentes e jovens com idade acima de 16 anos, tendo como um dos objetivos principais a preparação para a vida profissional. Os alunos, posteriormente, poderiam ser encaminhados para oficinas de trabalho protegido ou para o mercado competitivo.

Não pretendo discutir aqui questões relacionadas ao programa ou a proposta de profissionalização porque se desviaria do objetivo principal; a propósito, gostaria apenas de dizer que considero a questão ainda hoje um tanto controversa para a qual não encontrei uma resposta mais satisfatória4.

Minha intenção é retomar a experiência vivida com alguns alunos que faziam parte do programa, mais especificamente o que foi conhecido como um "treino de independência".

A idéia era na verdade bem simples. Tratava-se de uma saída da escola até a casa de um aluno por vez utilizando o transporte coletivo e fazer o retorno. Participariam os alunos de duas salas do Programa de Oficinas de Trabalho. Cada saída era destinada a apenas uma sala por vez, sendo que

\footnotetext{
${ }^{3}$ Seguindo a organização do Ensino Fundamental, cada período de aula tem duração de cinco horas. Além disso, deve-se acrescentar aproximadamente uma hora gasta no percurso percorrido da casa à escola e mais uma hora para o retorno, somando aproximadamente sete horas diárias em média. ${ }^{4}$ Esta é uma questão que ainda me causa incômodo embora venha pensando sobre isso há alguns anos. Escrevi um artigo há um certo tempo atrás (Kohatsu, 1998) onde apresentei a proposta de Emprego Apoiado que conheci na Espanha alguns anos antes da escrita do trabalho. Nesta proposta defende-se a idéia de preparação laboral de trabalhadores com deficiência mental no contexto real de trabalho e coloca-se em questão a manutenção de espaços protegidos/abrigados como alternativa de trabalho. Todavia, a minha questão sobre a profissionalização de pessoas com deficiência mental não se resume a este aspecto, mas me remete inevitavelmente a pensar sobre as contradições intrínsecas da sociedade capitalista.
} 
poderia ser feita por todos os alunos da sala (em média dez alunos) ou em pequenos grupos de dois a três alunos. Quando a saída era realizada com toda a classe havia o meu acompanhamento e o da respectiva professora; quando a saída era feita em pequenos grupos apenas eu acompanhava os alunos.

0 agendamento era feito previamente com os alunos e as famílias que se colocavam à disposição para nos receber. Em alguns casos as saídas foram planejadas para serem feitas em datas de aniversário ou, se não fosse possível coincidir, procurávamos a data mais próxima. Nesses casos a classe toda fazia a saída.

Após a visita ter sido combinada com o aluno e sua família, caberia a ele a condução do grupo até a sua casa, desde a saída da escola, a chegada até $o$ ponto de ônibus, a identificação do ônibus, a iniciativa para descer no ponto mais próximo e o trajeto até a casa. Eu costumava dizer aos pais que a responsabilidade da condução seria do aluno, mesmo porque nós profissionais não conhecíamos o local onde eles moravam e nem qual seria 0 ônibus mais adequado. Estaríamos servindo apenas como um apoio no caso do aluno se perder, procurando desse modo tranqüilizar um pouco os pais.

Antes da saída eu lembrava o aluno de sua responsabilidade, informando-o que ele deveria se informar a respeito do ônibus e que somente ele saberia o caminho. Nesse sentido, eu não procurava informações antecipadamente com a família e, algumas vezes, por não conhecer 0 trajeto, cheguei a acreditar que estávamos perdidos, fato que nunca chegou a acontecer. Nessas saídas aproveitávamos, também, para fazer uso do telefone público, visto que sua utilização não era familiar para muitos alunos.

Não chegamos a visitar a casa de todos os alunos, embora todos tenham participado das saídas. Em pequenos grupos visitamos a casa de três alunos e em grupo fomos a casa de seis alunos. Embora as saídas fossem sempre ricas em descobertas e surpresas, eu pessoalmente achava mais interessante a saída com pequenos grupos, pois os alunos eram obrigados a 
ficar mais atentos e depender menos do grupo. Quando saíamos com toda a sala observava que muitos deles, por se sentirem seguros no grupo e com a professora, não se preocupavam com cuidados básicos como olhar antes de atravessar a rua.

De toda forma, pude notar, de modo geral, como a postura dos alunos mudava quando saíamos, principalmente em pequenos grupos. Alguns alunos considerados como indisciplinados se apresentavam mais responsáveis e, de certo modo, o grupo se apresentava mais solidário, uns se preocupando e cuidando do outro. Nossa relação e a postura com os alunos também mudavam, pois na rua o tratamento não era de professoraluno como ocorria na escola, contexto em que freqüentemente cabia à autoridade chamar a atenção e corrigir o aluno; penso que éramos mais companheiros e cúmplices. Na rua afrouxávamos a obrigatoriedade de cumprir as expectativas e os papéis impostos institucionalmente e, nesse sentido, percebo o quanto pudemos aprender sobre os alunos, sobre 0 potencial que na escola não se revelava e o quanto passamos a respeitá-los a partir dessas descobertas. Penso que, pelo menos para mim, foi uma experiência que me fez mais próximo deles e, se eu não estiver enganado o que penso ser pouco provável -, aprendemos a confiar mais uns nos outros.

\section{Algumas histórias no ônibus e na rua}

A seguir relato três experiências: duas ocorridas no ônibus e uma na rua, durante o trajeto até a casa de um aluno.

As duas experiências vividas nos ônibus relatam dois modos distintos dos passageiros se relacionarem com os alunos. No terceiro relato, conto a minha experiência de ser guiado por um lado pelas ruas de seu bairro até chegarmos a sua casa. 


\section{Duas histórias no lotação, dois modos de ver a deficiência}

Partíamos quase sempre do mesmo ponto de ônibus que se localizava próximo à Praça da Matriz, no bairro do Rudge Ramos. Do ponto de ônibus que ficava ao lado de uma banca de jornal e próximo de dois supermercados, avistávamos a Igreja Matriz com sua grande cúpula arredondada, tal como a das catedrais européias.

Sempre entrávamos pela porta da frente do ônibus, como todas as pessoas, mas não atravessávamos a catraca. Eles mostravam a carteirinha de ônibus em que eram identificados como alunos de escola especial e, nós profissionais, como acompanhantes e, desta forma, não pagávamos a passagem.

Um dos problemas quando saíamos com toda classe era que um grande número de pessoas acabava se concentrando no pequeno espaço que a maioria dos ônibus reservava antes da catraca. Isso piorava nos horários de pico. Geralmente, pelo que me lembro, na ida os ônibus estavam mais vazios; o mesmo não ocorria no retorno que, independente do horário, vinha mais lotado, sem assentos disponíveis.

São Bernardo é um município que se estende por uma vasta periferia em que, para alguns lugares é preciso até utilizar a balsa, mas não chegamos a fazer esse percurso. Nossas viagens duravam em torno de uma hora.

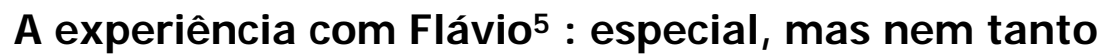

Estávamos retornando, o ônibus cheio e alguns dos alunos viajavam de pé. Um deles era Flávio, que estava ao meu lado. Não sei exatamente o que aconteceu, mas em certo momento uma mulher começou a irritar-se com ele, acusando-o de estar se encostando a ela. Ele não se defendeu,

\footnotetext{
${ }^{5} \mathrm{O}$ nome do aluno foi substituído para que fosse preservada a sua identidade.
} 
permaneceu calado, sorrindo. A mulher irritou-se mais ainda e, por não conhecê-lo, perguntou-lhe de que estava rindo. Nesse momento, tomei a defesa de Flávio. Disse que ele não estava rindo dela, mas que se tratava de sua expressão usual. Expliquei-lhe ainda que ele era um aluno de escola especial. Ela respondeu que também tinha problemas e que isso não lhe dava o direito de se esfregar nas pessoas. Não demorou muito, ela já estava de pé e desceu pela porta da frente, o que me deixou surpreso.

Pensei comigo mesmo que ela também deveria ser uma pessoa "especial". E inferi, então, o motivo pelo qual ela não demonstrou a mesma complacência que a maioria dos passageiros demonstra diante dos deficientes. E, talvez, por esse motivo, tenha tratado Flávio de igual para igual.

A princípio fiquei indignado com a reação da mulher, depois a surpresa pelo fato dela descer pela porta da frente e, finalmente, acabei questionando a minha atitude. Comecei a questionar se Flávio realmente não havia se esfregado na mulher, fato que daria razão à reclamação à senhora que foi molestada. Depois pensei, mesmo que ele não tivesse feito nada, por que eu deveria ter tomado a sua defesa? Por entender que ele não teria condições de se defender sozinho, por entender que eu era responsável por ele, pela necessidade de haver um mediador ou para aparecer como o herói bonzinho, defensor dos fracos diante do público? De qualquer modo, percebo que minha atitude reforçou aos olhos alheios o lugar de incompetência ocupado por Flávio, uma pessoa que, pela sua condição, não deveria ser responsabilizada por seus atos. Seria como dizer, "olha, não liguem, ele não sabe o que faz, ele é deficiente mental". Terá sido esta a mensagem que, de certa forma, foi passada ao público que nos assistia? Foi uma difícil lição para mim.

Hoje vejo que cotidianamente cometemos deslizes, mas raramente paramos para refletir sobre eles. Pelo contrário, na maioria das vezes penso que nós profissionais nos colocamos no lugar do defensor daqueles que são fracos e oprimimos. Não estou afirmando que devemos ser omissos, mas 
tomar o cuidado com o modo como procedemos e nos perguntarmos sobre qual é a real intenção de nossas ações. E, depois de toda essa discussão, ainda me pergunto: e se a mulher não fosse uma pessoa "especial"?

\section{A experiência com I vo}

Lembro-me, também, de outro episódio envolvendo passageiros, mas, diferentemente do primeiro, a passageira não se mostrou hostil, mas, ao contrário, mostrou-se bastante solícita.

Saíamos com toda classe, mas desta vez era uma viagem de ida e não de retorno. O ônibus estava vazio, a maioria estava sentada, mas eu e alguns poucos alunos viajávamos de pé.

Durante as saídas eu começava a indicar algumas vias principais aos alunos para que, aos poucos, eles pudessem memorizar os trajetos e os nomes de algumas ruas e avenidas, visto que passávamos quase sempre pelas mesmas: Caminho do Mar, Vergueiro, Kennedy, Paço Municipal etc. Para ajudar na memorização, certa vez pedi para que Ivo anotasse os nomes de algumas ruas principais por que passávamos, pois ele era o único aluno alfabetizado do grupo.

I vo estava sentado e eu de pé. Ao seu lado, viajava uma senhora. Não me recordo a partir de que momento começou a nos observar, mas claramente me recordo que, quando Ivo passou a escrever os nomes das ruas, ela não se conteve. Ele sabia escrever, mas sempre perguntava pela letra: "começa com "V"? E agora que letra que vem"? E eu insistia: "escreve do seu jeito". E ele, "é o "E", né"? E assim sucessivamente. Foi então que a senhora que estava ao seu lado, observando a minha recusa, entendeu que deveria ajudá-lo. Imagino que ela deveria se perguntar: "por que ele não diz logo quais as letras que o rapaz deve escrever"? Assim, quando ele me perguntava, ela prontamente passou a responder e, em certo momento, começou a ditar todas as letras sem que ele precisasse perguntar. Não soube o que fazer nessa situação, pois apesar de querer que Ivo tentasse escrever 
por conta própria, via que a senhora agia de boa intenção e poderia parecer um pouco antipático se eu lhe pedisse para não se intrometer. A certa altura I vo não pode mais contar com a ajuda da senhora, pois ela teve que descer. Confesso que se tratava de uma senhora muito simpática.

Pelo menos em minha memória estão registradas mais situações como essa do que a primeira que foi relatada. Muitas pessoas ao identificarem a condição dos alunos procuram ajudar, cedem seus lugares, conversam. E isso não ocorria apenas com os passageiros, mas com os cobradores e motoristas também, salvo algumas exceções, como já relatei.

\section{Percorrendo as ruas da periferia}

Após a longa viagem de ônibus, chegamos ao destino. Mas antes de descermos vem a dúvida: será que este é o ponto correto, como ter certeza? Não tínhamos, mas mesmo assim não sobrava alternativa e descíamos guiados apenas pela confiança que depositávamos em nossos guias.

Uma das ocasiões em que mais estive inseguro foi na visita à casa de Diogo, mas antes entendo que devo fazer uma breve introdução do nosso guia e anfitrião.

Ele era um rapaz que me chamava atenção. 0 que mais me intrigava a seu respeito era o modo como falava. Aliás, falava pouco e, quando 0 fazia, quase não conseguíamos ouvi-lo, pois falava muito baixo, sussurrando. Sua voz quase não saía de dentro de sua boca. Assim como Flávio, ele mantinha uma espécie de sorriso quando falávamos com ele.

Pouco sabíamos de Diogo, do que pensava, do que gostava ou não. Talvez por ser meio quieto, pouco falador ou pouco compreendido pela maioria das pessoas.

Quando falava ele esboçava um sorriso em sua boca, enrugava a testa levantando a sobrancelha, olhava para os lados e colocava a mão na cabeça. Como nem sempre eu conseguia compreender o que ele falava, 
procurava confirmar meu entendimento fazendo-Ihe perguntas que ele respondia apenas sinalizando com a cabeça.

Nós da escola escolhemos fazer uma saída com Diogo porque havíamos entendido que ele deveria ser urgentemente orientado para que não se perdesse mais, fato que ocorria na maioria das vezes em que ele, por iniciativa própria, saía de casa e se aventurava a vir sozinho para a escola em ônibus comum. Isso acontecia sempre que ele perdia a hora e, consequentemente, perdia 0 transporte escolar. E então ele não tinha dúvida. Imagino que devia recorrer ao primeiro ônibus que aparecia, mas nunca tive a certeza de como ele chegava, pois nós da escola nem sempre entendíamos o que ele dizia, apenas inferíamos a partir do que entendíamos. Várias vezes a Guarda Civil Metropolitana o trouxe para a escola, talvez por encontrá-lo perdido em algum lugar ou por ter sido encaminhado por alguma pessoa.

E então chegou o dia. Saímos em um pequeno grupo de três alunos. Fomos até 0 ponto de ônibus que ficava em frente à Praça da Matriz. 0 pai havia Ihe dito que o ônibus que servia era o de número 15 - Detroit. Escrevi o número em um pedaço de papel e ele deveria indicar quando o ônibus chegasse ao ponto. Diogo não sabia ler. Demorou um pouco, mas o ônibus chegou. Como sempre não atravessamos a catraca. Pelo que me lembro, fui durante todo o trajeto perguntando a ele se estávamos chegando. Acho que minha insegurança me tornou um pouco chato, mas Diogo não demonstrou aborrecimento. Quando chegou a hora, ele se levantou, olhou para mim e não disse nada. Parecia que ele falava com os olhos - "é aqui". Às vezes parecia que não apenas respondia, mas também perguntava, isto é, seu olhar também transmitia sua dúvida. E algumas vezes, eu não sabia discernir se seu olhar dirigido a mim era de resposta ou de pergunta. Enfim, descemos. "Pra onde é Diogo", e ele respondia baixinho e indicando com a mão: "é pra lá". Assim, atravessamos a avenida e nos embrenhamos pelo bairro. 
Era um bairro residencial de periferia com alguns pequenos comércios espalhados: bares, armarinhos, mercearias etc. Pequenas lojas que resistiram e que não haviam sido engolidos pelas grandes redes de supermercados. Eram casas simples, alguns eram sobrados. Não posso descrevê-los com mais detalhes, pois já faz alguns anos. 0 que ficou registrado era a cor predominante do cinza do cimento.

Fomos andando pelas ruas onde algumas pessoas pareciam nos observar. Dobramos uma esquina aqui, outra ali e não chegávamos. A certa altura perguntei a Denis se ele sabia onde estava andando. Botou a mão na cabeça, ficou me olhando. Indaguei se aquele olhar era de resposta ou de dúvida. Para mim, naquele momento, parecia de dúvida. Achei que estávamos perdidos. 0 que fazer, voltar ou prosseguir? Perguntei novamente se ele sabia onde estava e ele olha para o chão. Insisto e ele sinaliza afirmativamente com a cabeça. Pronto, está decidido, prosseguimos. Após caminhar mais alguns minutos chegamos a sua casa. Eu tinha o nome da rua e quando vi a placa me senti aliviado.

Quando chegamos, seu pai estava dormindo e sua sobrinha acordada. Pedi a Diogo para avisar que tínhamos chegado. Não nos demoramos e logo depois fomos embora, refazendo o caminho de volta à escola. 0 retorno também ocorreu sem problemas.

De certa forma, a experiência da incerteza, da dúvida e da desconfiança no aluno-guia não aconteceu somente dessa vez. Repetiu-se também quando fomos à casa de outros alunos, demonstrando que talvez não confiávamos tanto quanto gostaríamos, mas que, aos poucos, fomos aprendendo a confiar.

Essas foram algumas das várias histórias que vivenciamos e que agora me lembro. Certamente, se recorresse à memória dos companheiros de viagem, outras histórias interessantes seriam recordadas. Escolhi estas apenas para ilustrar algumas situações diferentes e inesperadas que ocorreram no espaço público do transporte coletivo e da rua com atores que contracenaram sem seguir o roteiro previamente estabelecido pela 
instituição. E esse é um dos motivos pelos quais me anima realizar a pesquisa do lado de fora dos muros da escola. A possibilidade de descobrir 0 que ainda não podemos vislumbrar quando estamos do lado de dentro.

\section{Problematização}

A delimitação do tema tem sido uma tarefa difícil para mim. Dificuldade comum dos pesquisadores iniciantes - apesar de já ter trilhado 0 mestrado - ou pela característica de certas pesquisas? Ambas, quem sabe.

Por que a dificuldade? Porque na medida em que a investigação caminha, o objeto, ainda pouco definido, parece mudar de cor, forma, tamanho, densidade conforme aproximo ou distancio o meu olhar sobre ele. $\mathrm{Na}$ verdade não sei o que está em mudança, se o sujeito que olha ou 0 objeto observado. Provavelmente ambos, um determinando o outro. E quando será que terei mais claramente, mais precisamente uma definição para saber sobre o quê estou falando? E se ele, o objeto, continuar escapando do foco a cada movimento meu6? É tão difícil quanto enquadrar uma criança que não para de se movimentar, que ora se esconde, ora foge ou se aproxima demasiadamente do fotógrafo fazendo com que ele perca 0 foco.

Neste momento entendo que minha tarefa seja reconstituir o caminho trilhado até que se chegue ao ponto de onde, atualmente, observo e constituo - com a minha observação e o meu olhar - aquilo que entendo ser meu objeto de estudo: a relação que ex-alunos de escola especial mantêm com o bairro onde moram mediada pela produção de um vídeo.

\footnotetext{
6 Em seu artigo "Algumas considerações sobre procedimentos metodológicos nas pesquisas educacionais” Bernardete Gatti (1999:74) aponta para um aspecto interessante: “Parece ser consistente com o próprio processo de investigação do humano-social admitir que o objeto é construído no próprio processo de pesquisa, a partir da aproximação dos problemas. Se nos debruçarmos sobre como as Ciências Humanas e Sociais hoje trabalham, nas tradições epistêmicas que mais avançaram, vemos que o trabalho investigativo se desenvolve a partir de questões relevantes no campo, sem se procurar precisar o objeto com acuracidade antes do trabalho de análise”.
} 
Realizada esta primeira delimitação, vejo decorrer dela muitas perguntas e esclarecimentos que devem ser feitos. Por que um vídeo, por que ex-alunos de uma escola especial e por que sobre o bairro onde moram? E ainda, o que estou entendendo como produção de um vídeo. Começarei pela última indagação por entender ser mais fácil para mim.

\section{A escolha do vídeo}

Por que um vídeo? Penso que, em primeiro lugar, pelo meu próprio interesse pessoal pela fotografia e pelo vídeo, tanto na condição de apreciador como de usuário amador, por considerá-los fascinantes meios de expressão e experimentação. Segundo, por se revelarem, indiscutivelmente, como ricos instrumentos de pesquisa, inclusive para as ciências humanas. Terceiro, pelo fato de ter trabalhado com o recurso visual (no caso a fotografia e o vídeo) em minha dissertação de mestrado (Kohatsu, 1999a) e, desse modo, ter apreciado muito a utilização desse tipo recurso na realização da pesquisa7. Quarto, pelas possibilidades oferecidas por esse meio como, por exemplo, o registro da imagem em movimento, o registro simultâneo da imagem e do som entre outras que Ihe conferem a dinâmica necessária para o tipo de pesquisa proposto.

A utilização e exploração deste de recurso implica, também, na aprendizagem e domínio de uma outra linguagem visual sobre a qual deixarei para discutir mais adiante, na parte sobre o método.

\section{A escolha dos participantes}

Por que ex-alunos de uma escola especial?

\footnotetext{
7 Nessa ocasião, a fotografia foi utilizada como meio de expressão dos participantes e, conseqüentemente, tomada como o objeto de estudo. No início da pesquisa eu estava em dúvida entre oferecer a fotografia ou o vídeo aos participantes, tendo optado pela fotografia pelo baixo custo do equipamento. Desse modo, pode ser oferecida uma câmara fotográfica para cada participante portar para onde quisesse e podendo esta ser usada sem o acompanhamento do pesquisador. O vídeo, desse modo, foi utilizado apenas como meio de registro dos encontros entre o pesquisador e os participantes.
} 
A escolha do grupo de participantes decorre de minha atuação profissional como psicólogo escolar na educação especial e, também, pela possibilidade de dar continuidade aos estudos já iniciados na pesquisa de mestrado, realizada também com alunos e ex-alunos de uma escola especial.

Diferentemente da pesquisa de mestrado em que participaram alunos e ex-alunos de escola especial (para alunos com deficiência mental), nesta pesquisa participarão somente ex-alunos.

Os motivos da escolha são os seguintes:

1. São pessoas mais velhas (acima de dezoito anos) e supostamente mais autônomas.

2. São pessoas que supostamente tiveram mais experiências de vida fora da escola especial.

3. São pessoas mais independentes no ir e vir e que não necessitam de acompanhamento da família.

O segundo motivo me faz pensar se, durante período em que essas pessoas permaneceram na escola especial, tiveram maior distanciamento do bairro em que moram. Penso nisso por três razões:

1. Pelo fato da escola se localizar, na maioria dos casos, fora e distante dos bairros dos alunos;

2. Em decorrência da distância casa-escola, muitos alunos utilizam 0 transporte escolar, implicando em maior permanência fora de casa e do bairro e por isso se privarem do conhecimento cotidiano do local onde moram;

3. Pelo fato dessas pessoas, na condição de alunos de escola especial, terem a independência restringida pela escola e pela família.

Fico agora pensando se a saída da escola especial, a perda do transporte escolar e a conseqüente necessidade do uso de transporte público proporcionaram, de alguma forma, o conhecimento do bairro, mesmo que parcialmente: o ponto de ônibus, o trajeto até a casa etc. Será que, de 


\section{fato, a permanência na escola especial dificultou ao aluno o conhecimento de seu bairro e será que a saída da escola proporcionou essa aproximação?}

Para finalizar esta parte da discussão, gostaria apenas de esclarecer que os participantes, doravante, serão denominados como ex-alunos de escola especial e não como jovens com deficiência mental. Não pretendo negar a condição da deficiência, mas apenas situá-la estrategicamente como "fundo" para a vida que aparece como figura8.

\section{Por que sobre o bairro onde moram?}

A partir da minha pesquisa de mestrado (Kohatsu, 1999a) algumas questões foram levantadas e não puderam ser aprofundadas naquele momento.

Um aspecto que me chamou a atenção foi em relação à escolha dos temas fotografados pelos participantes - vale esclarecer que estes eram de livre escolha dos fotógrafos, assim como o modo de abordá-los. Dentre todos, o tema "pessoas da família" foi o mais fotografado pela maioria dos participantes, sendo, também, o tema das fotos preferidas.

Ao analisar o contexto em que as fotos foram tiradas, pude notar que a maioria dos participantes fotografou em basicamente dois lugares: a casa e a escola. Mesmo as fotos de outros temas como objetos, plantas, animais etc. se inseriam nesses dois contextos.

Penso, desse modo, que a dissertação de mestrado revelou, de alguma forma, um pouco do cotidiano e da vida social dos participantes da Oficina de Fotografia - um universo constituído basicamente pela casa e pela escola, às vezes solitário, às vezes apenas na companhia de objetos, animais e plantas.

\footnotetext{
8 Aproprio-me da analogia feita pela Profa. Dra. Maria Eloísa D’Antino com a dissertação de mestrado intitulada "Resgatando o passado: deficiência como figura e vida como fundo", de autoria da Profa. Lígia Assumpção Amaral, na ocasião do Exame de Qualificação, atribuindo, portanto, os devidos créditos.
} 
Em alguns casos suponho que este universo social seja restrito inclusive por não terem independência para circularem pelo bairro, de irem sozinhos até a padaria da esquina. No caso de outros, o problema não parecia ser exatamente a falta de independência, pois circulavam sozinhos, mas talvez a dificuldade ou a falta de oportunidade ou afinidade para estar em contato com outras pessoas e estabelecer novas relações.

$E$, novamente, então, me questiono se este (hipotético) isolamento tem alguma relação com o fato de estudarem ou terem estudado numa escola especial.

A partir desses questionamentos elaboro outra pergunta:

Como se constituiu o universo social dessas pessoas (exalunos de uma escola especial) para além dos muros institucionais da escola especial?

Nesta pesquisa de doutorado minha intenção é realizar uma investigação "fora" do âmbito restrito e privado das instituições escolares e familiares para verificar de que modo os espaços públicos da rua e do bairro favoreceram (ou não) a constituição de algum vínculo social.

Sei que seria equivocado de minha parte acreditar que o espaço da rua não é atravessado por alguma forma de institucionalização, que nesses espaços não existam manifestações de poder, assujeitamento, subordinação, preconceito, segregação ou outras formas de opressão e violência tal como muitas vezes, infelizmente, encontramos nos espaços das instituições tradicionalmente estabelecidas como escolas, hospitais, presídios etc. A propósito, vale lembrar que o espaço da rua, principalmente dos bairros periféricos, é freqüentemente associado pelos meios de comunicação de massa como aquele ocupado e dominado pela violência. Mesmo na escola essa associação rua-violência é tomada de forma acrítica e, muitas vezes, nós profissionais criticamos as famílias que deixam seus filhos "soltos" nas ruas à mercê de toda sorte de coisas e pessoas de índole duvidosa. 
A rua é vista como local dos desocupados, vadios, bêbados, traficantes, viciados e indivíduos de toda espécie que não se enquadraram no esquema produção-consumo. Quem não tem o que fazer fica na rua ocioso, bisbilhotando, à disposição, pronto para ser cooptado pelo que há de pior.

Em relação à escola, ela é vista pelo senso comum como local de guarda, proteção, respeito, ordem e disciplina, onde se aprende a ser útil, prestativo e produtivo - ainda que seja pela submissão.

A escola e a rua se constituíram no imaginário social como faces opostas e complementares da mesma realidade social.

Quanto mais próximo o indivíduo estiver do pequeno e restrito círculo da produção e consumo da sociedade capitalista, melhor ele deverá administrar o seu tempo para que sua vida se torne a mais produtiva possível. Nessa perspectiva o ócio se torna inconcebível e mesmo as horas livres e o lazer passam a ser administradas pelas regras da produtividade. A vida social se restringe ou fica à mercê dos esquemas produtivos das empresas, sobrando pouco espaço para as relações espontâneas e não administradas presentes ainda em alguns espaços comunitários.

Nesse contexto a rua como espaço público e comunitário tende a se esvaziar e a vida social vai se tornando cada vez mais restrita ao espaço privado e doméstico ou limitada às corporações e instituições estabelecidas.

Estigmatizar o espaço da rua e negar o sentido social nela presente como, por exemplo, a solidariedade e o sentimento de pertencimento comunitário, pode ser uma estratégia ideológica utilizada contra as camadas populares que ficam à margem do esquema produção-consumo. Esta estratégia tem vários efeitos como, por exemplo, a culpabilização das pessoas que fazem parte desse estrato social e pelo fato de não estarem plenamente inseridas no esquema produção-consumo. É uma estratégia de esmagamento do poder de resistência, da auto-estima e da vontade de sobrevivência, criando um terreno propício para a manifestação da violência. 
Ao estigmatizar a população mais pobre e condenar seus modos de se relacionar, dificulta-se a percepção de que nos espaços periféricos das cidades existem e resistem modos de socialização muito pouco conhecidos por aqueles que não habitam esses locais, tal como apontou a tese de mestrado de Clemente (1998).

Não pretendo fazer uma apologia do espaço da rua - pois, como a escola, ela é também local de contradições - e nem tampouco desvalorizar o espaço da escola que pode em seu interior estimular a emancipação, tal como defendia Paulo Freire, uma escola como extensão da vida e não como espaço de alienação. Todavia, como já esclareci anteriormente, pretendo, nesse momento, voltar minha atenção para as relações que ocorrem ou ocorreram fora do contexto escolar e familiar, mais especificamente ao espaço da rua, do bairro onde moram essas pessoas, ex-alunos da escola especial. E então, uma segunda, complementar à primeira:

\section{Como vivenciaram e ocuparam o espaço do bairro? Quais foram as experiências mais significativas? Em que período ocorreram (infância, adolescência, fase adulta)?}

Inicialmente a idéia era mais genérica: investigar a relação e inserção destes sujeitos no espaço público da cidade. Com as orientações recebidas, pelas minhas condições e prazo da pesquisa optei por focalizar mais a relação com o bairro, ou seja, o entorno mais próximo.

Como foi relatado anteriormente, a maioria dos participantes da Oficina de Fotografia era moradora da periferia, assim como a maioria dos alunos das escolas especiais e provavelmente os participantes da pesquisa.

Esse dado é relevante pois, a meu ver, pode revelar um modo diferenciado de socialização, tal como alguns estudos têm mostrado. E daí decorre uma terceira pergunta: 


\section{Como é para essas pessoas (ex-alunos da escola especial) morar na periferia? Será que o contexto comunitário (se existente) favoreceu de algum modo a sua socialização?}

Estas são algumas das perguntas que consegui, até este momento, sistematizar ao longo deste breve caminhar pela pesquisa. Tomo-as muito mais como referências de origem, pontos de partida, como bases de lançamento que me impulsionam à investigação do que perguntas que necessariamente a pesquisa deverá responder. Como disse anteriormente, a cada passo sou obrigado a reajustar o foco sobre o objeto observado porque, assim como o próprio pesquisador se movimenta - e talvez em decorrência desse seu movimento - o objeto também se desloca e se reconstitui. Assim, no caminhar da pesquisa novas perspectivas poderão se abrir e talvez as perguntas terão que ser revistas, reformuladas ou recriadas.

Em relação a mim, na condição de pesquisador, posso dizer que estas perguntas que vão sendo formuladas têm me estimulado a refletir sobre a minha própria infância, sobre meu universo social, o modo como ele se constituiu a partir e fora da escola, a minha relação com o bairro onde eu morava e assim por diante, inspirando-me a retomar um pouco da minha própria trajetória.

Sei que é uma grande pretensão de minha parte, mas não posso deixar de revelar meu desejo de poder proporcionar aos participantes da pesquisa a oportunidade para refletirem sobre essas questões como a relação com a escola, com o bairro, com os amigos e, de certa forma, ajudar a resgatar um pouco da história e da memória de cada um deles.

Sobre a relevância da pesquisa, tenho pensado sobre ela desde o início. Não gostaria que esse estudo tivesse como resultado apenas a satisfação individual do pesquisador, que se reduzisse a um mero diletantismo, mas que de fato pudesse trazer alguma colaboração para as pessoas envolvidas e que pudesse ajudar na reflexão dos profissionais que trabalham na educação e, sobretudo, na educação especial. 
Para resumir, penso que a pesquisa pode colaborar, também, no sentido de colocar em discussão questões como:

- a experiência desses jovens para além da escola especial, para não esquecermos que eles não são somente alunos e deficientes, mas também pessoas que se relacionam com 0 mundo;

- os diversos modos de vida das pessoas que moram na periferia, para além dos preconceitos e dos estigmas, para não esquecermos que nesses locais não existe apenas violência e pobreza;

- os estigmas e preconceitos associados a pessoas com deficiência, alunos de escola especial e moradores da periferia;

- nosso modo de vida no contexto da sociedade capitalista, nossa relação com as pessoas, com o lugar onde vivemos.

\section{Retomando o fio da meada: a síntese da proposta}

Penso ser importante colocar os objetivos da pesquisa que são:

1. Proporcionar o conhecimento e a compreensão da relação que ex-alunos de escolas especiais mantêm com 0 bairro onde moram a partir da produção de um vídeo realizado pelos próprios participantes;

2. Analisar o processo de produção do vídeo em todas as suas etapas (que serão logo apresentadas) ${ }^{9}$.

\footnotetext{
${ }^{9}$ Este segundo objetivo foi posteriormente inserido após eu ter refletido que o processo de produção do vídeo (que implica na relação entre pesquisador e participante) é tão importante como material de estudo como o próprio produto em si, no caso o vídeo. Isto marca e caracteriza inclusive a metodologia empregada, em que o pesquisador não é um mero observador, mas interage ativamente com os sujeitos. E é por isso que digo que a pesquisa tem sido uma permanente elaboração, com mudanças, descobertas e re-significações a cada passo dado.
} 


\section{CAPÍTULO I}

\section{OLHANDO PARA O LADO DE DENTRO: A ESCOLA}

A escola é uma realidade complexa e multifacetada que pode ser "olhada", questionada, criticada, elogiada a partir de diferentes perspectivas. Neste capítulo e nesta pesquisa, ela será abordada como um espaço de vivências concretas, singulares e também um espaço onde se guardam memórias.

A minha intenção é subir ao sótão e tirar a poeira que cobre o baú, abrilo e deixar sair as recordações do passado, as fotografias antigas, as lembranças boas e outras que eu gostaria de tê-las esquecido, mas que também persistem em permanecer guardadas.

Recordar as experiências escolares é, de certo modo, recordar da própria infância. Este é um pouco do sentido e da intenção com que trago a escola para esta pesquisa, como um espaço que faz parte da infância, assim como o bairro, como seu contraponto.

Pretendo mostrar como a escola e o bairro mantêm uma relação de tensão - quando disputam a atenção e o interesse da criança, tal como ocorre no "Conto de escola", de Machado de Assis (1999) -, mas também de complementaridade - quando as relações ocorridas em uma se transferem para a outra. Se, por um lado, a escola priva a criança de estar no bairro, pois a guarda também se torna sua função, por outro, pode possibilitar à criança o conhecimento de outras crianças de seu bairro que até então não conhecia, aumentando, desse modo, seu universo social na escola e, também, no bairro onde mora.

A primeira parte está reservada ao relato de minhas memórias escolares: as lembranças da escola primária e o ginásio. Posteriormente recorrerei a 
algumas obras de ficção da literatura brasileira para trazer o depoimento de alguns personagens sobre suas experiências na escola: o ingresso no universo desconhecido, os novos vínculos e também as vivências amargas.

\section{Lembranças da escola primária}

Meu primeiro dia na escola aconteceu no ano de 1972, quando ingressei no primeiro ano primário, como era denominado naquela época - tempos da ditadura militar, do governo do Presidente Ernesto Garrastazu Médici. Eu olhava para seu retrato na parede e sentia $\mathrm{m}$ certo medo. I maginava um homem muito grande e austero, talvez por causa de seus cabelos mesclados de preto e grisalho e aquele terno escuro com uma faixa verde-amarela.

Tudo era novo e amedrontador para mim. Meu primeiro desafio foi ficar naquele pátio cheio de crianças barulhentas que não pareciam compartilhar os mesmos receios e anseios que eu. Elas pareciam familiarizadas com aquele tumulto e não se mostravam inibidas com tudo aquilo. Minha mãe havia me levado até a escola e de repente desaparecera - senti vontade de chorar. Estava sozinho, aterrorizado. Acho que naquela época ainda não tinham inventado o "período de adaptação" ou, se tinham, não se aplicava para aquela situação ou para aqueles alunos nos quais eu, infelizmente, me incluía. Não me mexia, nem sequer ousei ir atrás dela. Talvez por saber e entender que deveria permanecer ali e aguardar valentemente. Essa seria minha obrigação. Era a primeira vez que me separava de minha mãe, pois nunca havia ido a uma escola até esse dia.

Após a infinita espera, a professora chegou. Ela era elegante, para não dizer bonita. Mas depois falarei sobre ela.

As filas começaram a subir. Quando chegou a nossa vez, apenas segui. Eu observava e imitava as outras crianças. Havia algumas que choravam 
desesperadamente, mas isso achei melhor não imitar. Estava resignado que deveria enfrentar tudo aquilo.

Lembro-me dos cadernos brochura encapados cuidadosamente com plástico xadrez branco e azul, os lápis preto número dois, apontador, os lápis de cor e o conjunto de canetinhas Sylvapen. A lancheira com um furo na tampa para deixar sobressair a garrafinha de plástico branco com duas tampas: uma era para fechar o bocal - que muitas vezes vazava - e a maior, azul, que servia também como copinho. Tudo cheirava novo - aliás, como foram marcantes todos aqueles cheiros. Posso senti-los até hoje: o cheiro do presunto no lanche, o cheiro do suco de laranja na garrafinha de plástico, o cheiro dos colegas, dos cadernos e do plástico xadrez.

Tomamos o lanche na sala, assim como passamos a fazer os dias que se seguiram. Cada aluno tinha uma toalhinha que estendia sobre a carteira e a professora nos ensinava, depois de terminado o lanche, como pegá-la pelas pontas para não deixar as migalhas caírem. Novamente a fila para descer ao pátio, onde me senti um tanto deslocado, sem saber o que fazer, sem ter amigos. Enfim, o dia passou e eu havia sobrevivido ao fatídico primeiro dia. Confesso, todavia, que ao longo do dia já nem pensava mais na falta que sentia de minha mãe e da qual só fui me lembrar na saída, quando a reencontrei satisfeito comigo mesmo. Voltamos a pé para casa naquela tarde quente de verão, acompanhados por uma multidão de crianças e mães que faziam 0 mesmo trajeto. 0 uniforme suado, a lancheira vazia e o sentimento do dever cumprido.

Quando ingressei na escola, no primeiro ano, eu ainda não sabia ler e nem escrever. Mas isso não era um problema, pois naquela época era esperado que as crianças se alfabetizassem somente no primeiro ano. E assim foi que aconteceu - aprendi a ler e escrever com a Dona Cecília.

Fazíamos as lições no caderno; eram exercícios para treinar nossa habilidade com o lápis. Repetíamos as bolinhas, os tracinhos, as ondinhas, os 
zig-zag sem poder sair da linha. No princípio foi com certo esforço, mas depois a mão foi lasseando e fomos nos acostumando a pegar o lápis com o bico de passarinho, juntando o indicador ao polegar. Fazíamos também exercícios nas folhas mimeografadas, aquelas com 0 inesquecível cheiro do álcool. Posteriormente fomos conhecendo as letras minúsculas e depois as maiúsculas.

Aos poucos, sem nos darmos conta, estávamos lendo e escrevendo as primeiras palavras. Lembro-me que, certo dia, aprendi, sozinho, sem ajuda da professora, a escrever a palavra quartel! Teria sido uma coincidência ou influência do período militar? De toda forma, Dona Cecília se surpreendeu, me elogiou e eu me senti muito orgulhoso e capaz, sentimentos que não eram freqüentes nem predominantes em mim naquela época.

Eu achava a Dona Cecília elegante. Era alta, magra, tinha os cabelos pretos, uma voz suave e aveludada. Ela era afetuosa, mas sabia manter a distância necessária. Não a sentia como uma pessoa muito próxima de mim. Era tratado como mais uma criança da sala, diferentemente de como ocorreu no segundo ano, com a Dona Auta.

Pude encontrar Dona Cecília alguns anos depois. Ela morava perto de nossa casa e minha mãe havia se tornado sua manicura. Um dia fui visitá-la e, quando a encontrei, tive uma surpresa. Ela já não estava mais jovem e os fios de cabelo branco já começavam a apontar. E o mais curioso, ela não era uma pessoa alta. A minha lembrança havia se constituído a partir da percepção que eu tinha naquela época e depois parado no tempo. E então fiquei me perguntando, o que havia acontecido com ela, onde estava a Dona Cecília que eu havia conhecido?

Com o passar dos dias fui ficando menos tenso e me acostumando a permanecer no pátio na hora da entrada, de pé, olhando a nuca do colega da frente e, pior, tendo a sensação de que o colega de trás olhava a minha. Aos poucos ia conhecendo os colegas e aproveitávamos para conversar um pouco até que, um dia, uma mulher que tomava conta dos alunos veio com aquele 
olhar furioso e arregalado em minha direção e me deu um tremendo puxão de orelha. Acho que doeu mais na minha alma, pelo sentimento de ter sido injustiçado, do que na minha orelha que ardia em chamas. Não achei justo pelo fato de todas as crianças estarem fazendo aquela tremenda algazarra e somente eu ter sido punido. Será que eu havia me excedido? Duvido, pois eu era uma criança muito contida, no máximo poderia estar rindo e não cantando aquelas músicas que cantávamos todos os dias. De toda forma, a dor na orelha passou, mas ficou a pequena cicatriz nas minhas memórias escolares.

Como disse anteriormente, eu era uma criança excessivamente tímida, insegura, envergonhada e sofria muito com isso. Sentia-me inseguro até para pedir para ir ao banheiro. E um dia aconteceu. Esperava o momento certo para pedir, mas a professora não olhava em minha direção, pois estava passando de carteira em carteira dando visto nas lições. Comecei a ficar desesperado, a sentir calafrios, arrepiado. Minha possibilidade de espera se esgotava e eu não sabia como lhe chamar. E então aconteceu: havia defecado nas calças. Procurei esconder, mas o odor me delatou. Ou foram os colegas? Acho que eles não se sentiram constrangidos em denunciar o odor das fezes. No início não sabiam de onde vinha, mas haveria de acontecer, cedo ou tarde. E aconteceu: eu havia sido descoberto. A professora vinha, enfim, em minha direção, mas já era tarde demais. Ela me levou ao banheiro para que eu terminasse o que eu já havia concluído. E fiquei ali sozinho naquele banheiro vazio. Era um lugar calmo, silencioso, fresco de onde eu não queria sair mais. Afinal, como voltar para a sala de aula com a roupa toda suja, com as pernas sujas pelas fezes que escorreram. Ela retorna, ajuda-me com a higiene que de maneira alguma disfarçava o meu delito. Voltar com ela me deu um pouco mais de coragem, mas depois na sala de aula me via novamente só, com os colegas caçoando de mim. Foi bastante constrangedor. Não, foi inesquecível.

Sentia-me uma criança diferente e parecia que tudo acentuava essa diferença. Eu não era o único descendente de japoneses da sala. Havia um 
outro menino que logo se tornou meu amigo. Guardo até hoje uma foto em que estamos juntos, ambos caracterizados como caipiras para a festa junina. Estamos sentados na mureta que circundava aquela imensa árvore que até hoje impera no centro do pátio externo. Sua companhia, que não durou muito tempo pelo fato dele ter mudado de escola, fazia com que eu me sentisse menos sozinho, mas não suprimia o sentimento da diferença.

Não éramos ricos, mas minha mãe não poupava esforços para nos dar do melhor que podia oferecer. Para isso fazia algumas economias, como costurar ela mesma os nossos uniformes. A camisa era branca com o distintivo bordado no bolso - o mapa do Estado de São Paulo com o nome da escola. O short era azul marinho, assim como a calça comprida para os dias de frio, as meias brancas, o sapato preto e o conga azul para a educação física. A diferença no uniforme deveria ser mínima, indistinguível, mas para mim era notável. Era o corte da calça, a tonalidade do tecido, detalhes nos quais me apegava. Perguntava a mim por que eu tinha que ser diferente dos outros meninos se meu desejo era ser igual a eles. 0 fato é que minha mãe continuou costurando nossos uniformes até o ginásio, quando a certa altura os suprimiram. E então deixei de me preocupar com isso. 0 curioso é que o elemento que deveria tornar as crianças "uniformes" me fazia sentir diferenciado, ou seja, o esforço da escola em igualar as crianças evidenciava as pequenas diferenças. Mais tarde, a diversidade das roupas de passeio que usávamos serviu como uma camuflagem e então senti que me diluía na multidão.

Não era somente o uniforme que me diferenciava. Sentia-me também menor nas aulas de Educação Física. Eu não estava acostumado a fazer atividades físicas. Era uma criança que crescera em um apartamento. Minha mãe não permitia que eu descesse e ficasse na rua. Eu olhava lá de cima os moleques brincando, ficava apenas assistindo. Detestava as aulas de Educação Física, submeter-me a atividades que eu não conseguia fazer - aqueles malditos abdominais. Minhas habilidades faziam com que eu fosse sempre preterido na 
escolha dos times ou era daqueles que eram chamados sempre por último. Nunca fui capitão de time e demorou muitos anos até que eu marcasse um gol. Mas era na escola onde eu podia correr com prazer, não na quadra, nas aulas de Educação Física, mas pelo pátio. Aos poucos começava a participar das brincadeiras de pega-pega - esses espaços eram mais democráticos e participativos; nesses momentos não me sentia excluído.

0 meu segundo ano na escola foi diferente. Comecei a me destacar na sala de aula e passei a ser um dos preferidos da Dona Auta. Não me lembro precisamente de seu rosto, mas guardo a imagem de uma senhora de cabelos castanhos, baixinha e muito amável. Mas o que nunca me esquecerei é do modo carinhoso como me tratava, dos seus elogios, de seu afeto de professora. Nunca mais a encontrei e muitos anos depois de ter saído da escola soube que ela havia falecido.

Para mim era bom ser elogiado, servir de exemplo - naquela época eu não pensava nos efeitos que isso poderia ter para as outras crianças. Ela era uma professora muito carinhosa e acredito que fazia isso espontaneamente, sem necessariamente rejeitar os outros alunos. Não me lembro tampouco de ter tido problemas com os colegas da classe, apenas da rivalidade com a Salete, com quem eu disputava o primeiro lugar. Mas éramos amigos.

Despedi-me desse pequeno mundo no terceiro ano, quando tive a professora mais severa. Os cadernos eram encapados com papel manteiga verde-escuro. Comecei a detestar matemática. Conheci a violência da caneta vermelha no meu caderno. No final do ano mudei de escola. Minha mãe havia conseguido vagas para mim e para minhas irmãs em uma escola maior, embora mais distante de nossa casa. Diziam que era uma escola melhor, mais difícil.

Essa escola ficava em Pinheiros e não mais na vila. Dei início à experiência cosmopolita. Comecei a conhecer coisas que até então eu não tinha visto. Meu pequeno universo se ampliava, não por minha escolha, mas pela força das circunstâncias. 
Os colegas de classe moravam em altos prédios, eram mais ricos, freqüentavam clubes. Os pais exerciam profissões das quais os filhos se orgulhavam. Eles exibiam relógios, usavam roupas e tênis de marcas que eu nunca tinha conhecido. No início estranhava o fato deles darem tanta importância para coisas para as quais eu pouco me importava. Aos poucos foi se tornando uma exigência.

Não íamos mais a pé para a escola por causa da distância. Às vezes íamos de carro, mas minhas irmãs e eu tínhamos medo porque minha mãe ainda estava aprendendo a dirigir. Lembro-me que ela deixava o motor do carro morrer quando o semáforo se abria e os motoristas começavam a buzinar irritantemente. Nós então nos deitávamos no banco de trás para não assistir a tragédia. Às vezes em que íamos de ônibus eram mais tranqüilas.

Passei a estudar nessa nova escola na quarta série. Tudo era novo e eu começava tudo de novo. Diferentemente da escola anterior, nessa eu tinha duas professoras: a Dona Rosa e a Dona Dorotéia. A primeira ensinava Língua Portuguesa, História e Geografia. A outra ensinava matemática e Ciências. Para meu azar a segunda era a mais severa. Comecei a associar a matemática com a severidade das professoras.

Para minha sorte, logo no início, conheci um colega que também vinha da outra escola. Era o Eduardo. Assim como eu, ele também era descendente de japoneses. Tornamo-nos amigos por muitos anos.

No intervalo jogávamos bolinha de gude, batíamos figurinhas e brincávamos de ajuda-ajuda.

Ainda na quarta série tive mais uma vez a triste experiência de ser preterido. Foi durante os ensaios da quadrilha na Festa Junina. Nunca tinha visto uma quadrilha tão sem graça. Apenas alguns alunos foram escolhidos pelas professoras para dançar, os outros, como eu, ficavam de fora balançando lanterninhas. Fui deixado de lado porque era muito baixinho para fazer par com uma garota da classe. Foi escolhido então um outro aluno com pinta de 
galãzinho. E eles dançaram bonitos e felizes e eu fiquei com a minha incômoda inveja. Sentimentos que também se aprendem na escola.

\section{O ginásio}

O tempo passou e eu já me encontrava no ginásio. Passei a ter uma professora para cada disciplina. Minha professora de Matemática na quinta série foi a Dona Hiroko. Foi minha conciliação com a matemática. Durou pouco. Minhas notas na caderneta escolar decaíam a cada ano que passava. Na sétima série tive a experiência da cola e, também, da recuperação.

Deixava aos poucos de ser o aluno bonzinho na medida em que começava a experienciar a puberdade. Acho que nesse período aprendemos mais com as lições que não estavam nos livros e principalmente aquelas que são dadas fora da sala de aula.

Nesse período ocorreram também as lições sobre a sexualidade que, obviamente, não foram ensinadas pelas professoras. 0 assunto ainda não fazia parte do currículo. Eram trocas de experiências que aconteciam nas rodas de conversa com os colegas mais experientes.

Os anos vividos no ginásio foram se passando e, quando eu me dei conta, a infância havia passado definitivamente. Começaram a surgir as primeiras festinhas noturnas, a descoberta da paixão e também da desilusão. Foi assim que me despedi desse período. Terminado o ginásio, fui para a escola técnica ingressar em um novo universo e uma nova etapa começaria em minha vida. 


\section{Da realidade para a ficção: refletindo sobre a experiência vivida}

Ao reler as minhas recordações agora, com certo distanciamento, posso notar como alguns temas emergem e como deles decorrem questões interessantes para serem discutidas. Embora possam parecer experiências muito pessoais e particulares - e assim é, pelo menos do ponto de vista de quem as vive ou viveu - ao tomar certo distanciamento, posso notar como muitas delas podem ser vistas como experiências até muito comuns. Penso nisso ao comparar minhas experiências escolares com aquelas vividas por alguns personagens de romances brasileiros (alguns autobiográficos) - como Doidinho, de José Lins do Rego (1989) e Infância, de Graciliano Ramos (s.d.) - e também alguns contos como 0 caso da vara e Conto de escola de Machado de Assis $(1990,1999)$, entre outros que vou descobrindo e me surpreendendo.

Há muitas diferenças que me distanciam desses personagens como a época, o lugar e a cultura. Todavia, apesar da distância no tempo e no espaço, é possível encontrar algumas semelhanças nas experiências. $E$, talvez, por esse motivo é que se torna possível a minha identificação com personagens tão distintos, de contextos tão variados e longínquos.

E, embora eu tenha feito a opção de buscar inspiração para minhas reflexões apenas na literatura brasileira moderna, posso notar desde já, como algumas obras, mesmo marcadas fortemente pelo tom regionalista, carregam consigo a virtualidade de nos transportar para a dimensão do universal, possibilitando a compreensão da experiência do outro, mesmo quando ele está situado em um contexto espaço-temporal tão diverso do leitor. Talvez seja isso que possibilita nos identificarmos como humanos, apesar das nossas diferenças e particularidades.

Nessa caminhada pela leitura, como numa viagem, encontro personagens que vão se tornando companheiros ao longo da jornada. A leitura vai tomando a conotação de uma troca de confidências entre personagem e leitor, 
desenvolvendo um processo de identificação em que, gradativamente 0 personagem vai deixando sua condição de estranho para, aos poucos, tornar-se familiar. Nessa atmosfera de cumplicidade com o personagem, passo a compartilhar com eles as dores, as angústias, as expectativas, as frustrações, as descobertas, as delícias e as alegrias das experiências vividas em um período, como a infância, em que somos tão abertos e receptivos e, quem sabe por isso, tão vulneráveis a cada gesto, palavra, olhar, silêncio, recusa, tão intensamente vividos. A descoberta da vulnerabilidade do outro e de nós mesmos possibilita, por sua vez, a aprendizagem do sentido e do valor da solidariedade como elemento necessário para a sobrevivência, principalmente em lugares hostis, como muitas vezes a escola se mostra.

Antes de finalizar esta nota introdutória, gostaria de dizer que a minha opção por trazer apenas obras da literatura brasileira não ocorreu por nenhum critério muito elaborado; trata-se apenas de uma escolha pessoal de um leitor que tardiamente descobriu esse patrimônio e que, nesse momento, se vê encantado por esse horizonte que se abre. Para mim, vejo que descobrir a literatura brasileira é como descobrir parte da nossa própria história, parte da nossa memória e da nossa identidade.

0 que o leitor encontrará a seguir serão alguns temas suscitados a partir da releitura das minhas memórias escolares como a experiência do ingresso na escola, o ambiente social formado pelas professoras e pelos amigos e também a reflexão sobre algumas experiências amargas. A cada um desses temas apresento trechos das obras literárias como forma de ilustração.

\section{O ingresso no universo desconhecido}

No meu tempo a institucionalização escolar começava bem mais tarde do que hoje. Ingressei no primário quando já tinha sete anos, portanto íamos para escola já sabendo andar, falar, correr e fugir, habilidades essenciais para o 
enfrentamento ou fuga de determinadas situações constrangedoras promovidas pela escola e, mesmo assim, quantas vezes nos dávamos mal!

Enfrentar a escola pela primeira vez não foi nada fácil para mim, mas pude notar como esta dificuldade não foi somente minha. Veja, por exemplo, 0 caso de Carlinhos ou, melhor, Carlos de Melo - como passou a ser chamado na escola o personagem do romance “Doidinho", de José Lins do Rego (1989).

Ele era um menino de doze anos, criado e crescido no engenho de canade-açúcar e tinha como referência principal na família o avô, o Coronel Zé Paulino, e o tio Juca. Nessa idade Carlos já não compartilhava a companhia dos pais, pois a mãe havia sido morta pelo pai considerado doente mental, fatos que foi conhecer somente por intermédio da crueldade de colegas.

Carlos foi levado pelo tio Juca à escola, onde ficaria como interno por meses consecutivos, sendo recepcionado pelo Senhor Maciel, o autoritário diretor, visto pelos alunos como carrasco e temido pelas palmatórias que distribuía abundantemente aos alunos. Após breve apresentação, Carlos separase de seu tio com tristeza:

E o meu tio me chamou para o abraço. Parecia que me deixava de vez, porque foi com o coração partido que me cheguei para perto dele.

- Estude. Em junho venho Ihe buscar.

Saí chorando. Era a primeira vez que me separava de minha gente, e uma cousa me dizia que a minha vida entrava em outra direção." (Rego, 1989, p.04).

Em "Infância" Graciliano Ramos (s.d., p.104) relata também sua entrada na escola:

A notícia veio de supetão: iam meter-me na escola. Já me haviam falado nisso, em horas de zanga, mas nunca me convencera de que realizassem a ameaça. $\underline{A}$ escola, segundo informações dignas de crédito, era um lugar para onde se 
enviavam as crianças rebeldes. Eu me comportava direito: encolhido e morno, deslizava como sombra. As minhas brincadeiras eram silenciosas. E nem me afoitava a incomodar as pessoas grandes com perguntas. (...) A escola era horrível - e eu não podia negá-la, como negara o inferno. Considerei a resolução de meus pais injusta. Procurei na consciência, desesperado, ato que determinasse a prisão, o exílio entre paredes escuras. Certamente haveria uma tábua para desconjurar-me os dedos, um homem furioso a bradar-me noções esquivas. Lembrei-me do professor público, austero e cabeludo, arrepiei-me calculando o vigor daqueles braços. Não me defendi, não mostrei as razões que me fervilhavam na cabeça, a mágoa que me inchava o coração. Inútil qualquer resistência. (grifo nosso).

O autor imaginou uma escola que, de fato, não encontrou, diferentemente do personagem Carlos; aliás, Graciliano Ramos parecia descrever a escola do romance de José Lins. Continuando sua narrativa sobre 0 primeiro dia Graciliano Ramos (s.d., p.107) escreve:

Lavaram-me, esfregaram-me, pentearam-me, cortaram me as unhas sujas de terra. E, com a roupa nova de fustão branco, os sapatos roxos de marroquim, 0 gorro de palha, folhas de almaço numa caixa, penas, lápis, uma brochura de capa amarela, saí de casa, tão perturbado que não vi para onde me levavam. Nem tinha tido a curiosidade de informar-me: estava certo de que seria entregue ao sujeito barbado e severo, residente no largo, perto da igreja.

Para seu alívio, sua a professora não era um homem austero que dava castigos físicos como o diretor Maciel; era uma senhora baixinha, gordinha, de cabelos brancos por quem mais tarde se afeiçoaria. Mas até chegar esse momento ele descreve seu sofrimento e depois de um outro aluno:

Fileiras de alunos perdiam-se num aglomerado confuso. As minhas mãos frias não acertavam com os objetos guardados na caixa; os olhos vagueavam turvos, 
buscando uma saliência na massa indistinta; a voz da mulher gorda sussurrava docemente. Dias depois, vi chegar um rapazinho seguro por dois homens. Resistia, debatia-se, mordia, agarrava-se à porta e urrava, feroz. Entrou aos arrancos, e se conseguia soltar-se, tentava ganhar a calçada. Foi difícil subjugar o bicho brabo, sentá-lo, imobilizá-lo. O garoto caiu num choro largo. Examinei-o com espanto, desprezo e inveja. Não me seria possível espernear, berrar daquele jeito, exibir força, escoicear, utilizar os dentes, cuspir nas pessoas, espumante e selvagem. Tinham-me domado. Na civilização e na fraqueza, ia para onde me impeliam, muito dócil, muito leve, como os pedaços da carta de $A B C$, triturados, soltos no ar. (Ramos, s.d., pp.107-108)

A entrada na escola representa para a criança a transição para um outro universo social, diferente do ambiente familiar em vários aspectos. Para muitas é vivida como uma ruptura dolorosa, para outras, pode ser vivida de uma maneira mais tranqüila, menos traumática, mas, de toda forma, é um caminho sem volta, pois a criança não retornará mais a mesma para casa.

$\mathrm{Na}$ escola nem todos sabem o nosso nome e nem nós sabemos o nome de todos. No Ensino Fundamental, como o "meu primário" é atualmente denominado, principalmente nas séries iniciais, é comum a professora da sala conhecer o nome dos alunos e freqüentemente os alunos saberem, também, 0 nome da professora. Todavia, essa proximidade vai diminuindo quanto mais avançamos na carreira estudantil e, assim, mais nos tornamos anônimos e as relações entre professor e aluno vão se tornando cada vez mais formais a ponto de não sermos mais tratados pelo nome e, por correspondência, vamos deixando de memorizar, também, o nome dos professores de tantas disciplinas que passamos a ter. Quem foi mesmo a professora de geografia da sétima série? Ou terá sido um professor?

O nome, de certa forma, também faz parte de nossa identidade e nos indica, de certo modo, o tipo de relação que estamos estabelecendo. Na escola, por exemplo, quando os alunos são tratados pelo nome, nem sempre são 
chamados da mesma forma como em casa, pois não é raro as pessoas terem apelidos ou modos mais afetivos de serem chamados. No romance de José Lins do Rego, por exemplo, o personagem nota também esta diferenciação. Por sua gente, como ele se refere ao ambiente familiar, era tratado como Carlinhos, na escola passou a ser chamado de Carlos de Melo, nome e sobrenome.

Era a primeira vez que me chamavam assim, com o nome inteiro. Em casa, era Carlinhos, ou então Carlos, para os mais estranhos. Agora, Carlos de Melo. Parecia que era outra pessoa que eu criara de repente. Ficara um homem. Assinava o meu nome, mas aquele Carlos de Melo não tinha realidade. Era como se eu me sentisse um estranho para mim mesmo. Foi uma cousa que me chocou esse primeiro contato com o mundo, esse dístico que o mundo me dava. A gente, quando se sente fora dos limites da casa paterna, que é toda a nossa sociedade, parece que uma outra personalidade se incorpora à nossa existência. O Carlos de Melo que me chamavam era bem outra cousa que o Carlinhos do engenho, o Seu Carlos da boca dos moradores, o Carlos do meu avô. (Rego, 1989, p.06).

Na escola, é comum também ganharmos apelidos, mas geralmente nada agradáveis. Carlinhos, por exemplo, acabou ganhando um apelido nada afetivo: "Doidinho".

Fazia um mês que eu chegara ao colégio. Um mês de um duro aprendizado que me custara suores frios. Tinha também ganho o meu apelido: chamavam-me de Doidinho. O meu nervoso, a minha impaciência mórbida de não parar em lugar, de fazer tudo às carreiras, os meus recolhimentos, os meus choros inexplicáveis, me batizaram assim pela segunda vez. Só me chamavam de Doidinho. E a verdade é que eu não repelia o apelido. Todos tinham o seu. (Rego, 1989, p.12) 
Na escola perdemos um pouco da familiaridade e da intimidade a que estamos acostumados no ambiente mais protegido de casa. Deixamos de ser um pouco daquele que éramos para sermos um outro, desconhecido até para nós mesmos. Passamos a ser estranhos num mundo de estranhos e passamos a compor anonimamente a massa. Talvez seja isso que torna a escola tão assustadora para a criança, onde ela de início não consegue discriminar na paisagem indistinta e hostil aquele que oferece perigo daquele que poderá se tornar um amigo.

\section{Colorindo a paisagem: a criação dos vínculos afetivos na escola}

\section{A professora}

Em minhas recordações cito duas professoras do primário. São aquelas que estão mais distantes no tempo, porém mais próximas na memória.

Vejo também, pelo menos no meu caso, que quanto mais novos somos na escola mais importantes são as professoras para nós; os amigos aparecem em segundo plano como coadjuvantes ou meros figurantes. Existem as exceções e essas são feitas para os amigos inesquecíveis. Com o passar dos anos, vamos deixando um pouco de lado a importância que dávamos para as professoras e dividindo nossas atenções com os amigos. Na adolescência os professores parecem sair de cena para esta ser ocupada pelos amigos e a sala de aula deixa de ser definitivamente o espaço mais importante da escola.

Em "Infância" Graciliano Ramos mostra a surpresa do menino quando se defronta com a professora que, felizmente, não cumpriu suas temidas expectativas. Quem Ihe aparece não é o sujeito barbado, cabeludo, severo e furioso, mas uma senhora baixa, gorda e de cabelos grisalhos. Ele reservou um capítulo especialmente a Dona Maria. Há vários trechos onde ele a descreve com ternura: 
Aquela brandura, a voz mansa, a consertar me as barbaridades, a mão curta, a virar a folha, apontar a linha, o vestido claro e limpo, tudo me seduzia. Além disso a extraordinária criatura tinha um cheiro agradável. (Ramos, s.d., p.110)

O menino via sua professora com admiração e como uma pessoa diferente daquelas que ele estava acostumado a conviver, com cheiros fortes de fumo, suor, banha de porco, mofo, sangue, bafos, dentes escuros. Ele notava que o castigo físico não era também seu meio usual de corrigir as falhas dos alunos, diferentemente de como lhe ensinavam em casa e também do que era exigido na escola:

A escola exigia palmatória, mas não consta que o modesto emblema de autoridade e saber haja traduzido lágrimas a alguém. D. Maria nunca o manejou. Nem sequer recorria às ameaças. Quando se aperreava, erguia 0 dedinho, uma nota desafinava na voz carinhosa - e nós nos alarmávamos. As manifestações de desagrado eram raras e breves. A excelente criatura logo se fatigava da severidade, restabelecia a camaradagem, rascunhava palavras e algarismos, que reproduzíamos. (Ramos, s.d., p.111)

Pelo que o menino descreve, sua professora parecia ser uma educadora situada além do seu tempo, período em que o castigo e a severidade eram sinônimos de boa educação, como mostra o romance "Doidinho". Mas sobre o castigo gostaria de retomar um pouco mais adiante. Um outro aspecto que me chamou a atenção nessa narrativa é o modo como a professora conduzia sua classe, não como uma professora infalível, autoridade detentora do saber que teria como dura missão disciplinar e ensinar alguma coisa aos selvagens alunos. Sobre isso ele escreve: 
Felizmente D. Maria encerrava uma alma infantil. 0 mundo dela era o nosso mundo, aí vivia farejando pequenos mistérios nas cartilhas. Tinha dúvidas numerosas, admitia a cooperação dos alunos, e cavaqueiras democráticas animavam a sala. (Ramos, s.d., p.111)

E a atenta professora não examinava apenas a lição. Certa vez, observando a sujeira em sua orelha, perguntou ao menino se as tinha lavado e ele gaguejando respondeu que sim, mais por dedução do que por convicção, pois se havia lavado o resto, devia ter lavado as orelhas também. D. Maria, sem severidade, aconselhou apenas que ele tratasse delas com mais cuidado. Aquele modo de advertência deixou-o confuso e envergonhado e surtiu muito mais efeito do que se tivesse apanhado. 0 garoto empenhou-se tanto na sua higiene que as orelhas ficaram com esfoladuras.

Ainda sobre ela o escritor (Ramos, s.d., p.114) descreve:

D. Maria não era triste nem alegre, não lisonjeava nem magoava o próximo. Nunca se ria, mas de boca entreaberta, dos olhos doces, um sorriso permanente se derramava, rejuvenescia a cara redonda.

Um pouco mais adiante continua:

Dona Maria não tinha sede de justiça, não tinha nenhuma espécie de sede, mas era bem-aventurada: a sua alma simples desejava pouco e se avizinhava do reino de Deus. Não irradiava demasiado calor. Também não esfriava. Justificava a comparação de certo pregador desajeitado: "Nossa Senhora é como uma perua que abre as asas quando chove, acolhe os peruzinhos." (...) D. Maria representava para nós essa grande ave maternal - e, ninhada heterogênea, perdíamos, na tepidez e no aconchego, os diferentes instintos de bichos nascidos de ovos diferentes". (Ramos,s.d.,p.114) 
O garoto revela como a professora the possibilitou tranqüilidade, confiança, amparo e aprendizagem.

Sem dúvida, professoras como a D. Maria, a Dona Cecília, a Dona Auta foram figuras muito significativas que ajudaram a colorir os dias e os anos que passamos na escola.

\section{Os amigos}

Em "Infância", Graciliano Ramos (s.d., p.111) não traz relatos de amizades feitas pelo garoto na escola, pois, explica: “Vários tipos mostraram indiferença ou antipatia". O mesmo não aconteceu com Carlinhos de "Doidinho". No romance de José Lins do Rego (1989), quem colore a paisagem escura e opressora da escola não é uma professora, mas um amigo: o Coruja.

José J oão, o Coruja, havia sido apelidado por causa de sua cara redonda e dos olhos miúdos. Era um garoto esforçado, de uma família que pagava seus estudos com sacrifício, e que, ao contrário de Carlinhos e outros alunos, gostava muito de estudar. Certa vez seu pai havia decidido tirá-lo da escola por motivos financeiros, o que lhe causou profunda dor.

Carlinhos conta que até conhecer Coruja "nunca tivera um amigo, um, fora da família, a que fosse ligado como a um irmão. Sim, um irmão. (...) Esse meu primeiro amigo me revelara o que Deus não me dera: um irmão". (Rego, 1989, p.29)

Essa amizade entre Coruja e Carlinhos foi fortalecida especialmente em virtude de um acontecimento na escola. Carlinhos, não suportando os rigores da escola, as palmatórias injustas e a distância do engenho, teve certa vez a idéia de enviar uma carta à sua gente para que viessem lhe buscar e pediu para que Coruja a escrevesse. Mas, o mais notável, não foi a cumplicidade com o amigo, mas a sua lealdade. Após a vinda do avô de Carlos, o diretor chamou-o para 
inquirir sobre quem havia escrito a carta e quem a havia postado. Diante do silêncio de Carlos, o diretor aplicou-lhe a palmatória e mandou que chamasse 0 Coruja. Este, ao ver as lágrimas e o sofrimento do amigo, não teve dúvidas e confessou prontamente diante do interrogatório, assumindo para si o castigo. A atitude corajosa de Coruja fez aumentar o prestígio diante do amigo.

Amizades assim são realmente raras. Ensinam-nos 0 valor da solidariedade, da lealdade, da coragem, enfim, virtudes que não podem ser ensinadas por meios artificiais porque são valores que devem ser vivenciados para que possam ser apreendidos, incorporados. Mas, ainda assim, a escola pode ser um ótimo espaço para essa aprendizagem, como mostraram os rapazes.

Das minhas lembranças escolares não guardo nenhum episódio como esse vivido por Carlos e Coruja, essa prova de fogo em que a amizade deles foi submetida.

Nos primeiros anos de escola tive também muito poucos amigos. Lembrome de meu primeiro amigo na escola. Ele tinha um nome japonês de difícil pronunciação. Era muito estudioso e era bom ter um amigo assim, era estimulante. Mas essa amizade não durou muito, pois, ainda no primeiro ano, ele mudou de escola. Senti-me como Carlos diante da saída de Coruja, desamparado, sem amigos. A escola ficou até sem graça, principalmente na hora do recreio. Durante as aulas eu não devia ter sentido tanto, porque me ocupava com as lições e não dava para conversar mesmo. Mas na hora do recreio eu devia ficar vagando sozinho pelo pátio ou devia ficar sentado. I magino que o tempo do recreio devia ser interminável.

Hoje, refletindo sobre isso, pergunto-me o motivo pelo qual escolhi um amigo também descendente de japoneses e vejo que a resposta não é muito difícil. Como havia escrito anteriormente, sentia-me uma criança diferente por vários motivos e também pelos meus traços: os olhos, o cabelo, o tom da pele. 
Questiono-me o quanto a consciência da diferença nos induz a buscar a aproximação com o semelhante ou ainda, com aqueles com os quais temos alguma identificação. Quando estava no ginásio e depois também no colegial, notava como alguns colegas descendentes de japoneses buscavam se agrupar. O curioso é que, embora eu tivesse grandes amigos nikkeis ${ }^{1}$, tanto no ginásio como no colegial, preferia evitar o agrupamento dos iguais. Os agrupamentos, na minha imaginação, deviam chamar muita atenção para uma diferença que talvez eu quisesse diluir ou disfarçar. Negar a identidade surge então como uma estratégia de sobrevivência.

É possível que as minhas escolhas de amigos tenham se pautado também por esse critério, o critério que se chama hoje diversidade. $A$ diversidade, todavia, não era adotada em função de uma consciência crítica, mas como meio de evitar a segregação. Estar no meio daqueles considerados diferentes de mim, os não nikkeis, deveria ser imaginado por mim, ainda que de modo não claro e consciente, como uma camuflagem, um mimetismo. Tornarme um camaleão seria um modo de não chamar a atenção para mim e, assim, não correr o risco de me tornar um bode expiatório.

No romance "Doidinho" (Rego, 1989) pode-se notar como a identificação de alguma diferença torna-se um pretexto para que o indivíduo identificado vire motivo de chacota. Exemplos não faltam, como o caso de Licurgo, filho de prostituta; Aurélio, o doente; e mesmo o próprio Carlinhos, apelidado de doidinho. A ridicularização do diferente, a estigmatização não é realizada somente pelos profissionais da escola, mas também pelos próprios colegas. $A$ busca da amizade na escola pode ser, desse modo, uma necessidade para a sobrevivência do indivíduo em um meio percebido como hostil. Assim, a amizade pode ter a função de aliança para que se possa suportar os momentos de adversidade e também um meio para ajudar a passar o tempo, quando este se estender diante das situações enfadonhas. Todavia, penso que além dessa

\footnotetext{
${ }^{1}$ Modo como são referidos os descendentes de japoneses
} 
função de auxílio para as situações aversivas a serem enfrentadas - das quais não se pode fugir e nem se esquivar -, a amizade pode ser também o elemento que torna a escola um lugar atrativo, um motivo que nos faça querer comparecer.

Além da amizade, penso que o amor é um outro elemento que torna a escola um local bastante interessante. Em "Doidinho", a descoberta da paixão por Carlinhos fez com que a escola tivesse um outro colorido, mesmo após a saída de seu amigo Coruja da escola.

No universo da escola, as relações afetivas, os vínculos que vão sendo criados com a professora, os amigos, os amores, colaboram para que esse espaço se torne mais significativo, mais colorido e atraente e, assim, fazem com que alguns dias se tornem inesquecíveis em nossa história, dignos para serem recordados.

\section{As vivências amargas}

Infelizmente a nossa passagem pela escola não se dá somente com as boas lembranças. É lá que aprendemos muito mais do que as lições dos livros. Aprendemos a suportar o confinamento, os castigos, o medo, a injustiça e o sentimento de fracasso. Mas infelizmente, nem todos suportam. Alguns tentam fugir, escapar, outros a protestar e alguns, ou muitos, são expulsos de diversas maneiras. Para aqueles que permanecem, ficam marcados pelas vivências que dificilmente esquecem.

\section{As regras, a punição e a injustiça}

Aos poucos o novato começa a aprender as regras, afinal, todo espaço escolar tem regras. Geralmente e, em maior número, as regras começam com "não pode", "não deve", "é proibido", "é obrigatório" ou seja, mais restrições e 
imposições que reforçam a imagem de prisão. As regras servem para educar as crianças e as punições devem ser aplicadas para corrigi-las, diria o senhor Maciel, diretor da escola de Carlinhos. É possível que o próprio Carlinhos concordasse com isso e até compreendesse o sentido e a necessidade do castigo, mas o que ele vivenciava no internato era mais do que uma correção; era 0 abuso do poder, a pena desmedida, a expressão da crueldade e do autoritarismo. Assim, com o castigo, não se aprendia o que era correto, mas 0 seu inverso; aprendia-se a noção de injustiça.

Carlinhos conta como os castigos the foram aplicados injustamente pelo diretor por causa de suas dificuldades nos exercícios militares do Tiro: "Começava agora a me sentir perseguido pela injustiça, a sofrer sem nenhum pretexto". (Rego, 1989, p.137).

Nas minhas lembranças da escola guardo também uma ocasião em que fui injustamente castigado. Foi aquele episódio em que uma mulher, não me recordo qual era a sua função na escola, veio em minha direção quando eu estava na fila e me deu um tremendo puxão de orelha. Decerto, eu devia estar conversando na fila, assim como muitas crianças, mas, de toda forma, achei a punição exagerada. Como escrevi anteriormente, a dor na orelha passou, mas ficou uma pequena cicatriz nas minhas memórias escolares.

O castigo corporal imputa a dor no corpo e a revolta na alma diante da humilhação; faz aquele que apanha sentir-se como se fosse um ser insignificante, desprezível. Uma dor sem honra nem glória, desnecessária.

Como se pode ver, o castigo corporal é vivido pela criança como a expressão do terror, da malvadeza e da arbitrariedade do mais forte e não como um ato de correção e de justiça. Aquele que bate, que espanca, logo toma gosto pela coisa e não consegue mais botar freio na vontade de bater, que se transforma num impulso irracional, desmedido, perdendo qualquer relação com a intenção educativa. Torna-se pura expressão da violência, um meio de descarga da 
agressividade do mais forte, um ato de vingança. 0 poder de provocar a dor e 0 sofrimento no outro se torna fonte de prazer e o castigo torna-se o fim em si mesmo. Mas o adulto somente toma consciência dessa monstruosidade que pratica quando o monstro que criou, produto de sua violência, rebela-se e retorna na mesma moeda o que sofreu. A criatura, dominada pela revolta provocada pela arbitrariedade do agressor, deixa de ser submissa quando percebe que já pode revidar a violência sofrida. Nesse momento, aquele que castiga perde sua autoridade, baseada apenas na superioridade da força.

$\mathrm{Na}$ escola espera-se que os alunos sejam submissos à autoridade e acatem silenciosamente até os abusos, mas isso nem sempre ocorre, como no caso de Gringuinho (Rawet, 2000) que não suportou o castigo e esmurrou o peito da professora e o caso de Elias, do romance "Doidinho" (Rego, 1989). Este último, um rapaz de dezoito anos, foi o único que enfrentou o autoritarismo do diretor. Mostrou-se resistente ao castigo e entrou em confronto físico com o senhor Maciel que levou desvantagem por causa da idade. Ao perder sua autoridade e não podendo mais fisicamente com 0 aluno, o diretor não teve alternativa e decidiu pela expulsão de Elias que, segundo Carlinhos, era "um selvagem, incapaz de submissão". (Rego, 1989, p.72).

0 que aprendemos, afinal, com a dor do castigo e da humilhação? Pelo visto, além do ressentimento, a vítima aprende que o único meio de escapar é revidar com mais violência a violência sofrida, reproduzindo, assim, seu círculo infindável.

\section{A vivência do fracasso}

A escola para muitas crianças é também o local onde elas conhecem a experiência do fracasso. A dificuldade que alguns alunos apresentam para aprender certas coisas deveria ser entendida como parte do processo de aprendizagem, mas a escola, freqüentemente, não tolera 0 não saber das 
crianças, fato que parece bastante incoerente, se entendemos que elas estão ali justamente para aprender. 0 não saber não é visto como uma condição a ser superada pela criança com a ajuda da escola, mas surge como uma ofensa ao professor, provocando-Ihe a raiva, como se frustrasse sua expectativa, revelasse sua impotência e denunciasse também a sua incompetência. Diante dessa situação a criança é muitas vezes humilhada e culpabilizada pelo seu não saber - como se tivesse a obrigação de saber de tudo - e, assim, toma para si, sozinha, a responsabilidade por não ter conseguido aprender, incorporando 0 sentimento do fracasso.

Carlinhos entrou atrasado na escola, mas em pouco tempo conseguiu adiantar-se. Mesmo assim, sentia-se como um "burro" e tinha essa convicção (Rego, 1989, p.79), como aquele que não dá para os estudos. Quando pensou ter superado o estigma de incapaz de fazer as lições, vieram os exercícios militares para the recordar novamente as suas limitações. Ele não conseguia acompanhar o ritmo dos exercícios, apresentava sérias dificuldades com a lateralidade - quando todos viravam para a direita, ele se virava para a esquerda. Após muitas tentativas, gritos e castigos chegaram à conclusão de que ele não deveria participar do desfile militar. Ele Estava excluído e sua incompetência e inferioridade definitivamente comprovados.

Nem todos temos os mesmos talentos, as mesmas habilidades e nem por isso deveríamos nos sentir inferiores. As diferenças na escola raramente são entendidas como características individuais, mas como incompetência, pois todos deveriam ser igualmente competentes em tudo. Desse modo, as chances para alguns diminuem cada vez mais, ao passo que para outros as oportunidades sempre aparecem. Nessa perspectiva sobra pouco espaço para a solidariedade. $\mathrm{E}$ tudo isso muitas vezes é vivido como natural. 


\section{Vivenciando a delação, a vergonha e a humilhação}

A crueldade não é um privilégio dos agentes oficiais, assim como os alunos não são sempre as vítimas. Aprendem também a tomar o posto do opressor observando como ele exerce tão bem o poder e com tanto prazer, sem sequer se colocarem em conflito, sem questionamentos.

No colégio de Carlinhos (Rego, 1989) o poder não era exercido somente pelo diretor. Havia também Felipe, 0 decurião que imagino que exercesse a função de um inspetor de alunos. A ele também agradava o exercício do poder. $\mathrm{Na}$ ausência do diretor, era ele quem deveria impor a ordem no colégio. Para ironia do destino, Felipe deixa o cargo que passa a ser ocupado pelo melhor amigo de Carlinhos. Coruja tornara-se o novo decurião. Ele deveria exercer a função para poder continuar estudando na escola sem pagar. Era o único meio de poder voltar à escola.

Carlinhos não acreditava que o amigo pudesse se tornar subserviente como o antigo decurião, ser capaz de agir como um espião a serviço da tirania. Acreditava que Coruja pudesse exercer sua função de uma maneira mais humana. Mas, Coruja tornara-se um delator em função de seu cargo. Não 0 exercia com satisfação, mas como dever.

Há, entretanto, casos em que a delação de um colega acontecia sem nenhum pudor. Em "Conto de escola", de Machado de Assis (1999), que se passa em 184, narra a dura experiência do garoto Pilar.

Raimundo, filho do mestre, chama sussurrando por Pilar, devido ao medo que sentia pelo pai. Ele tira de seu bolso uma moeda de prata e mostra-a ao seu colega, ofertando-Ihe. Mas era um negócio, uma troca; a moeda pela lição. Pilar aceita, guarda a moeda no bolso e em seguida passa a "cola" da lição ao colega. De repente, Curvelo, um aluno da sala, flagra a negociação e delata-os ao mestre com satisfação. Os dois são chamados à mesa do professor que the toma-Ihe a moeda, atira-a à rua e após o sermão aplica-Ihes a palmatória. Pilar 
só pensava em quebrar a cara do dedo-duro, pois afinal, por que ele havia de denunciá-los? Nesse dia Pilar havia aprendido uma lição com Raimundo e Curvelo que the "deram o primeiro conhecimento, um da corrupção, outro da delação (...)". (Assis, 1999, p.30).

No romance de José Lins do Rego, o personagem Carlinhos passa também por uma experiência de delação. Ele estava apaixonado por Maria Luísa, sua colega de classe, e resolve the escrever um bilhete. Para seu azar, quando se encaminha à carteira da amada para entregar o bilhete, não percebe que 0 deixa cair, sendo encontrado por Felipe, o decurião. Este entrega 0 bilhete ao diretor que lê a mensagem para toda sala escutar. Uma gargalhada geral. Carlinhos pensa: "Seria melhor que ele me quebrasse logo de palmatória. Aquela exibição dos meus arrebatamentos doía-me mais do que os bolos". (Rego, 1989, p.35). A vergonha Ihe doía mais do que o castigo corporal.

Pilar e Carlinhos tiveram a experiência da delação, da humilhação pública $^{2}$ e da vergonha na escola. Em minha história registro também experiências em que fui alvo de zombarias, como na vez em que evacuei na sala de aula, e também quando fui delatado por outro colega. Dessa vez, fomos em bando para a diretoria por causa de um Magiclick que era usado para dar choques nos colegas, esta era a diversão, ver o colega saltando da cadeira.Embora eu não tivesse sido o executor, sugeri o nome de um colega que não achou muito divertida a nossa brincadeira e resolveu nos delatar. Oficialmente, o caso foi solucionado com a advertência oral dada pelo diretor, mas, até ser dada a sentença, amarguramos a dura ameaça da expulsão.

\footnotetext{
${ }^{2}$ Ulisses Araújo (1999) também faz uma discussão sobre o conto de Machado de Assis em seu livro homônimo "Conto de Escola: a vergonha como um regulador moral”, como o próprio título indica, sobre a perspectiva da moral.
} 


\section{A vontade de não ir, a necessidade de fugir}

Em Conto de Escola, Machado de Assis (1999) conta, além a experiência dolorosa aprendida na sala de aula por Pilar, a dúvida do menino entre ir a escola ou ficar na rua. Neste dia, a caminho da escola, ele hesita entre o morro de S. Diogo e o campo de Sant'Ana. Sabemos qual foi a sua decisão e as conseqüências dela - pobre rapaz - se soubesse o que o esperava, não teria feito essa escolha, mas também, não existiria esse conto.

Resolvido o dilema, decidiu-se por ir a escola, mas, pouco depois, já estava na sala de aula revelando seu arrependimento:

Com franqueza, estava arrependido de ter vindo. Agora que ficava preso, ardia por andar lá fora, e recapitulava o campo e o morro, pensava nos outros meninos vadios, o Chico Telha, o Américo, o Carlos das Escadinhas, a fina flor do bairro e do gênero humano. Para cúmulo de desespero, vi através das vidraças da escola, no claro azul do céu, por cima do morro do Livramento, um papagaio de papel, alto e largo, preso de uma corda imensa, que bojava no ar, uma coisa soberba. E eu na escola, sentado, pernas unidas, com o livro de leitura e a gramática nos joelhos"(Assis, 1999, pp.09-10).

Muitos garotos como Pilar fazem diariamente a escolha pela escola e muitos também, como ele, devem expressar o arrependimento diante das experiências ruins e desagradáveis que vão se sucedendo dentro dos muros. Alguns, porém, não se conformam e tentam a fuga. Sobre isso há um outro conto $^{3}$ de Machado de Assis (1990) chamado "O caso da vara" que relata uma tentativa.

O conto narra a fuga de Damião do seminário numa manhã de sexta-feira de agosto. Após a fuga, ele não sabia para onde ir, além do que não conhecia

\footnotetext{
${ }^{3}$ Existem algumas semelhanças nos contos no que se refere aos dilemas morais vividos pelos personagens, como poderá ser visto.
} 
bem as ruas. Não poderia retornar à casa do pai, pois este, após um bom castigo, obrigaria Damião retornar ao seminário; tampouco poderia ir à casa do padrinho João Carneiro que era muito mole e sozinho não ajudaria. Resolveu então que iria para casa de Sinhá Rita, uma viúva querida de seu padrinho, que poderia convencê-lo de que o melhor era mesmo que ele saísse do seminário. $\mathrm{E}$ assim o fez. O conto narra, além do drama da fuga, um dilema vivido pelo seminarista na casa de Sinhá Rita, mas esta parte deixaremos para uma outra ocasião.

Há um outro conto que relata a fuga de um aluno após o confronto com sua professora. Gringuinho, de Samuel Rawet (2000), conta a fuga desesperada de um garoto e, mesmo em casa continua perturbado, misturando flashes do episódio recente com os pequenos acontecimento da rotina de casa. Tomado pela mistura de cenas e sensações, não consegue sequer contar à mãe sobre o ocorrido, imaginando que ela nem Ihe daria a devida atenção:

E não contaria que, ao ser repreendido na escola, na impotência de dar razões, quando a velha principiou a amassar-lhe a palma da mão com a régua negra e elástica, não se conteve e esmurrou o peito rasgando o vestido. (Rawet, 2000, p.155).

Lembro-me também da vez em que, no ginásio, juntamente com um grupo de amigos estávamos pulando o muro da escola - prática que virava hábito - quando fomos surpreendidos pela mãe de um colega que passava na rua naquele exato momento. Nem tivemos tempo para nos preocupar.

Não posso dizer que naquela época pulávamos o muro, escapávamos, pelo fato da escola ser aversiva como aquela vivida por Carlinhos ou Pilar. Não é desse modo que me lembro desse período. Fugíamos porque o lado de fora proporcionava a sensação da liberdade, de andar, de conversar, enfim, coisas que não podíamos fazer dentro da escola. 
Na escola não sofríamos mais a repressão física - afinal esse tempo havia passado. A violência tomava outros contornos, menos definidos, e as marcas se tornavam mais difíceis de serem identificadas. De toda forma, havia razões pelas quais não queríamos estar ali. A fuga se tornava uma alternativa, uma forma menos violenta de rebelião, de insubmissão.

\section{Dando um giro na espiral: reflexões sobre as experiências}

A escola é um lugar de experiências diversas e por isso temos recordações tão diferentes com sentimentos tão ambivalentes: alegria, tristeza, saudade, esquecimento, companheirismo, rivalidade, conquista, fracasso, honra, vergonha, elogio, humilhação, revolta...

$\mathrm{Na}$ escola aprendemos muito mais do que a ler, escrever, a somar e subtrair. Muitas das "lições" vivenciadas na escola, carregamos pela vida toda, pois passam a fazer parte de nossa história.

Entendo que as relações sociais compõem um dos aspectos mais significativos da experiência escolar, mesmo elas tendo uma feição acolhedora ou ameaçadora. É disso que nos lembraremos, das relações que estabelecemos, bem ou mal, com as professoras e com os colegas. Tanto as professoras quanto os colegas são os mediadores, a ponte que nos conduz às experiências boas e ruins, ao aprendizado das lições escolares formais e não formais, das coisas que aprendemos dentro e fora da sala de aula e também dentro e fora da escola.

Penso que dificilmente a experiência escolar seja pouco significativa para uma criança, principalmente nos primeiros anos escolares. Primeiro: porque amplia seu universo social, antes restrito ao ambiente familiar; segundo: porque significa uma ruptura, ou seja, as relações que a criança estabelecerá na escola não são da mesma natureza daquelas que ela vivenciava em sua casa. Desse 
modo, a escola representa para a criança a oportunidade de ampliar suas relações sociais tanto no aspecto quantitativo como no aspecto qualitativo, ou seja, ela não apenas conhece mais pessoas, mas aprende a estabelecer outras formas de relacionamento.

A entrada na escola significa a saída do ambiente familiar e doméstico e, pelo menos para o senso comum, a saída do ambiente acolhedor ${ }^{4}$. A criança migra do espaço privado da casa para o espaço público da escola. Nesse sentido, a ida para a escola pode ser considerada como o primeiro passo no caminho da emancipação.

0 aprendizado e as experiências realizadas na escola podem favorecer à criança o contato com o seu bairro na medida em que a torna mais independente e capacitada para poder explorá-lo, contudo, o inverso nem sempre é verdadeiro, pois as experiências obtidas do lado de fora, ainda não são tão valorizadas pela escola.

São duas formas de aprendizado e conhecimento, uma complementar à outra: o que é aprendido na escola é o conhecimento formal ${ }^{5}$ e 0 aprendido no bairro é considerado o informal. Todavia, na escola também ocorre 0 aprendizado do conhecimento não formal, sobre o qual estive discutindo durante todo tempo. A escola, infelizmente, ainda não aprendeu a olhar para esse outro conhecimento que ocorre do lado de fora de seus muros, mas que também acontece em seu interior, ali mesmo, dentro da sala que aula. A escola ao fechar os olhos para este tipo de conhecimento, o saber informal, espontâneo, que envolve as relações sociais, deixa do lado de fora as condições para que se dê a produção de conhecimento em seu interior.

\footnotetext{
${ }^{4}$ Sei que as coisas nem sempre são como mostram as propagandas de sabão em pó e de margarina. Aliás, sobre isso trata o livro “O mito da infância feliz” (Abramovich et al.,1983), onde diversos autores relatam experiências de quando eram crianças e nem sempre eram felizes.

5 Essa discussão a respeito da especificidade do conhecimento escolar pode ser encontrado nos livros "Pedagogia Histórico-crítica” (Saviani, 2003), "Escola e o conhecimento - fundamentos epistemológicos e políticos” (Cortella, 2002) e "Perspectivas atuais da educação” (Gadotti et al.., 2000)
} 
Gostaria de finalizar este capítulo transcrevendo o belo prefácio escrito por Paulo Freire (1996, pp.9-10) para o livro de Georges Snyders ${ }^{6}$ que trata da alegria na escola, alegria que certamente colorirá muito mais as nossas memórias. Eis o trecho:

A alegria na escola, por que Georges Snyders vem lutando, alegremente, não é só necessária, mas possível. Necessária porque, gerando-se numa alegria maior - a alegria de viver -, a alegria na escola fortalece e estimula a alegria de viver. Se o tempo da escola é um tempo de enfado em que educador e educadora e educandos vivem os segundos, os minutos, os quartos de hora à espera de que a monotonia termine a fim de que partam risonhos para a vida lá fora, a tristeza da escola termina por deteriorar a alegria de viver. É necessária ainda porque viver plenamente a alegria na escola significa mudá-la, significa lutar para incrementar, melhorar, aprofundar a mudança. Para tentar essa reviravolta indispensável é preciso deixar bem longe de nós a distorção mecanicista; é necessário encarnar um pensar dinâmico, dialético. O tempo que levamos dizendo que para haver alegria na escola é preciso primeiro mudar radicalmente o mundo é o tempo que perdemos para começar a inventar e a viver a alegria. Além do mais, lutar pela alegria na escola é uma forma de lutar pela mudança do mundo.

\footnotetext{
${ }^{6}$ Trata-se do livro “Alunos felizes: reflexão sobre a alegria na escola a partir de textos literários” (Snyders, 1996).
} 
O trabalho está organizado em cinco capítulos.

Apresento dois capítulos iniciais propondo uma discussão sobre a escola no primeiro capítulo e uma discussão sobre o bairro no segundo.

No Capítulo I, ao escrever sobre a escola procurei retratá-la, sobretudo, como um espaço de experiências significativas, dos aprendizados sobre a convivência social e não somente como o lugar onde se dá a transmissão do conhecimento formal. 0 que recordo em minhas memórias são as vivências boas e ruins que tive com as professoras, com os amigos. 0 mesmo procuro fazer quando trago à cena algumas obras literárias de ficção, a partir dos depoimentos dos personagens sobre suas vivências na escola. A minha intenção, portanto, foi mostrar como a escola ocupa um lugar importante e marcante em nossa formação pessoal e, tal como o bairro, faz parte do universo vivido na infância e na juventude.

Após as memórias da escola, no Capítulo II, relato as minhas memórias no bairro. Recordo as experiências da infância e da juventude, os amigos, a vizinhança, a vinda do circo e do parque de diversões no terreno baldio. Comento também sobre as mudanças que ocorreram em meu bairro: as casas que foram demolidas dando espaço aos novos prédios; antigos moradores sendo "expulsos" para bairros mais distantes, dando lugar a outros mais abastados.

Ainda no capítulo sobre o bairro, escrevo sobre as minhas experiências de viagem, responsáveis pela formação do meu espírito de viajante, do olhar que me permite retornar ao espaço conhecido e me surpreender diante do que parecia familiar. Essa vontade de conhecer, de viajar certamente foi responsável também pela vontade que alimentei de conhecer o bairro dos participantes.

Finalizo este capítulo contando sobre a minha mudança para o $A B C$, realizando alguns comentários sobre a região.

O terceiro capítulo está dividido em duas partes; primeiramente realizo uma discussão sobre o método e depois apresento a proposta da pesquisa. Sobre o método, explicito a opção pela abordagem qualitativa, a 
presença da orientação fenomenológica e a inspiração na pesquisa de tipo etnográfico. Realizo posteriormente uma discussão sobre a utilização dos recursos visuais e sobre o uso do vídeo na pesquisa. Na segunda parte retomo os objetivos e as perguntas norteadoras da pesquisa e, posteriormente apresento os participantes, os procedimentos, a organização e o tratamento dado ao material obtido.

No quarto capítulo apresento as experiências videográficas. I nicio com a apresentação do trabalho de Luzia sobre a favela Boa Vista, que considero como uma experiência-piloto e, posteriormente, apresento os trabalhos de Mário sobre a Vila Rosa e o trabalho de Márcio sobre o Jardim das Orquídeas.

Procurei manter nos três trabalhos uma estrutura comum com basicamente duas partes: na primeira realizo uma breve apresentação do participante e, em seguida, apresento o relato dos encontros; a segunda parte é destinada ao trabalho de compreensão, discussão e reflexão acerca do material produzido que, por sua vez, é subdividida em dois itens que abordam o "bairro como espaço vivido" e o "tempo vivido no bairro". 0 primeiro discute os locais gravados e as relações sociais mantidas no bairro; o segundo retoma aspectos relativos às memórias sobre o bairro e também sobre as memórias do narrador sobre a sua própria história. Apesar da estrutura comum, procurei respeitar a especificidade de cada experiência e, por esse motivo, cada trabalho se apresenta de modo bastante particular.

Após a discussão individual dos trabalhos, realizo uma discussão conjunta das três experiências e, ao final, proponho uma discussão a respeito das possíveis contribuições dadas pela pesquisa, apontando também as possibilidades de outros estudos decorrentes dela.

o quinto e último capítulo é reservado para as considerações finais. 


\section{CAPÍtULO II}

\section{OLHANDO PARA O LADO DE FORA: O BAI RRO E A CI DADE}

Neste capítulo apresento e discuto algumas questões relativas às vivências e memórias do bairro e da cidade.

Tanto um como o outro são lugares por onde vamos transitando ou permanecendo, na condição de nômades ou de sedentários, e vamos deixando as marcas de nossas experiências. 0 bairro e a cidade tornam-se grandes diários a céu aberto, com os seus traços, suas marcas e seus símbolos registrados ao longo do tempo. O espaço vivido, desse modo, torna-se parte de nossa própria história. Cabe a nós, agora, o trabalho arqueológico. A tarefa é reconstituir, a partir das pegadas, dos vestígios, dos fragmentos, um pouco do que se passou; recordar, enfim, o que ficou.

Assim como no capítulo anterior, parto das minhas próprias lembranças da infância que guardo do bairro onde vivi. Em seguida, um olhar sobre o tempo passado mais recente: a minha relação com o bairro já adulto: um olhar de despedida, pois em seguida comento a minha mudança para a região do $A B C$.

Sobre o $A B C$, mais especificamente sobre São Bernardo, parto do meu olhar de estrangeiro e realizo algumas tentativas de compreensão desse lugar ainda pouco conhecido por mim. 


\section{$\underline{\text { Vila Beatriz }}$}

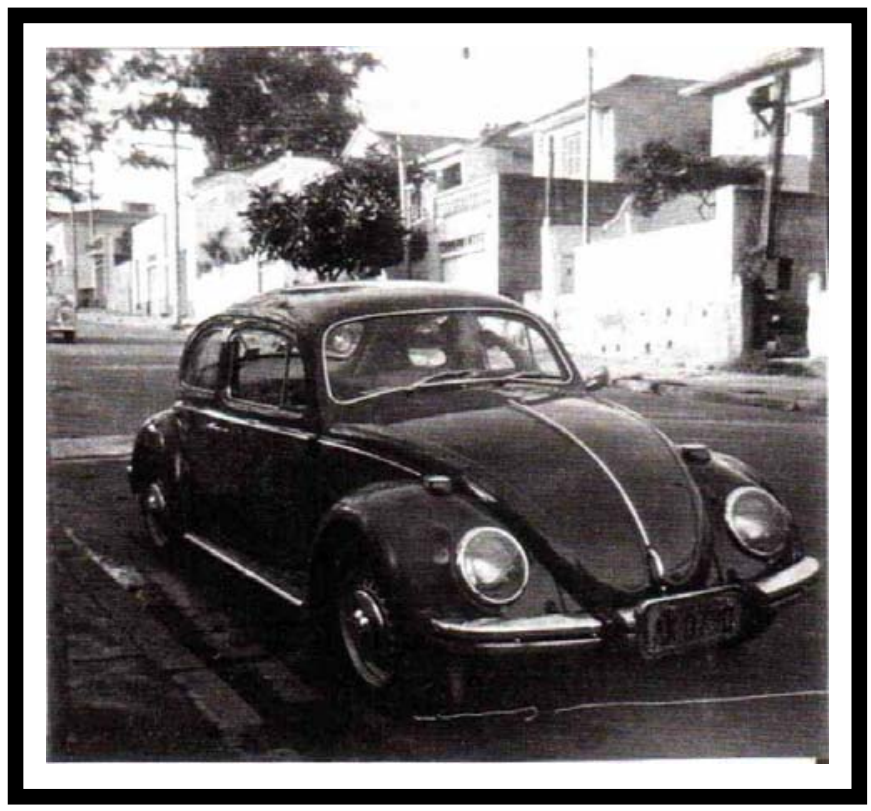

Década de 70

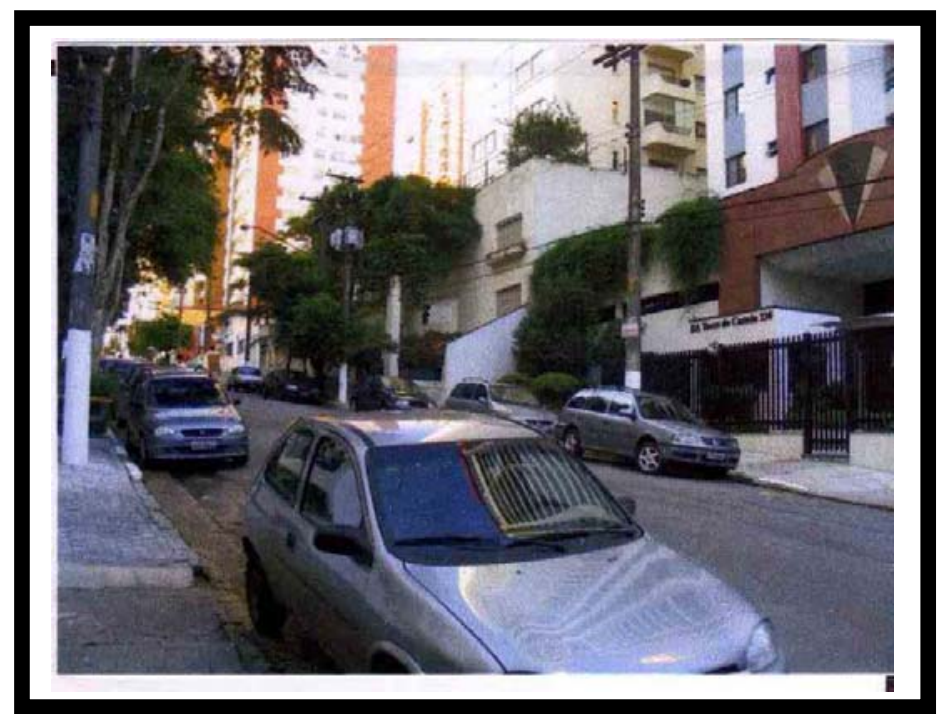




\section{A saudosa Vila Beatriz}

Conta minha mãe que mudamos para o apartamento da rua Isabel de Castela ${ }^{1}$ por volta de 1968 , portanto, quando eu tinha cerca de três anos.

É um apartamento médio (foto 1), não muito grande, nem muito pequeno. Tem uma sala, dois quartos, cozinha e banheiro. Ele fica no segundo andar de um prédio de cinco apartamentos. Sua fachada é coberta de pastilhas azuis e amarelas. Embaixo do prédio há anos funcionou uma farmácia. Hoje, o espaço é ocupado por uma loja de presentes.

O nosso prédio durante muitos anos foi 0 único na vila. Era como uma torre de onde avistávamos vários lugares distantes. Agora ele fica espremido entre os altos prédios que o cercam, um

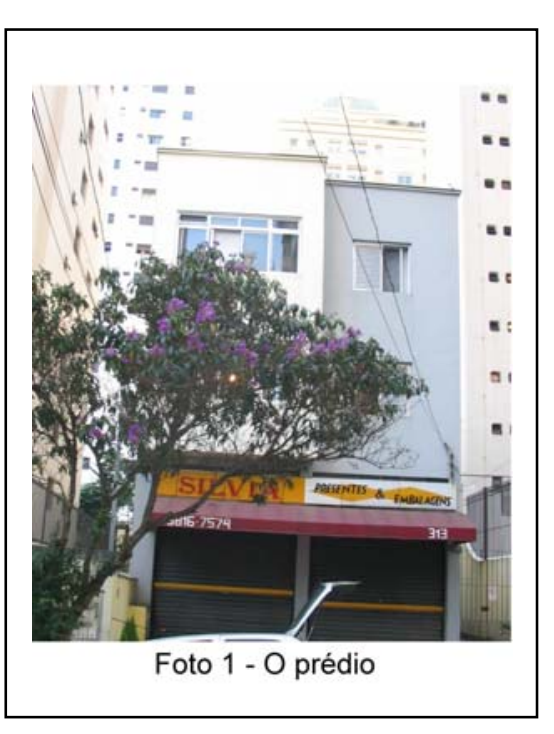
anão entre os gigantes. Lembro-me também que ao lado de nosso prédio

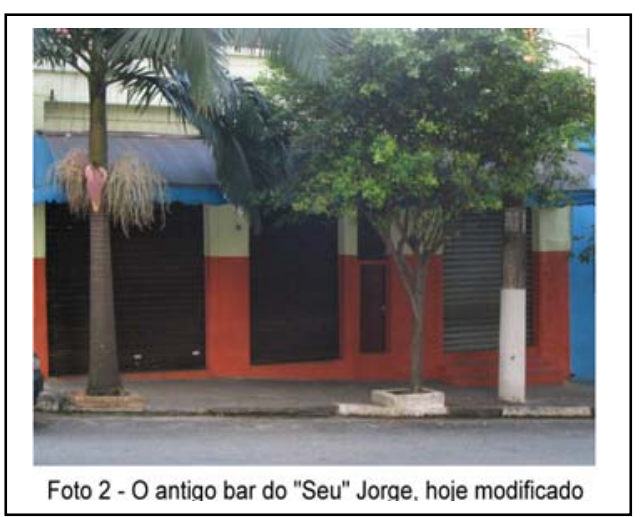
havia um bonito e grande sobrado que foi demolido juntamente com uma pequena casa, situada na esquina, onde funcionava o consultório médico do Dr. Soriano.

Poucas construções sobreviveram para servirem de testemunhos de uma época não muito remota. Do outro lado

da rua restaram três pequenas casas. Na do meio funcionava o bar e a mercearia do Seu Jorge (foto 2 ), na verdade um lugar onde se vendia de tudo. Há anos ele transferiu o ponto e hoje funciona apenas o bar.

Ao observar as fotos da rua onde eu morava, feitas por mim exclusivamente para a tese, começo a notar um aspecto interessante. Na

\footnotetext{
${ }^{1}$ Muitos anos mais tarde, talvez quando eu já estava na escola, descobri que Isabel era a rainha do reino de Castela que se casou com o rei Fernando. Unidos pelo matrimônio, unificaram o reino da Espanha no século XV, período em que Colombo veio para as Américas e os mouros começaram a ser expulsos da Península Ibérica.
} 
altura da rua onde se situa o prédio onde eu morava ocorre um divisor de águas, quero dizer, visualizo uma linha imaginária que divide a rua no tempo e no espaço. De onde está situado o prédio, subindo a rua (foto 3 ), formouse a nova Vila Beatriz, ocupada por altos prédios para a classe média. Rua abaixo (foto 4), preservou-se, de certa forma, as antigas construções, as casas e os sobrados.
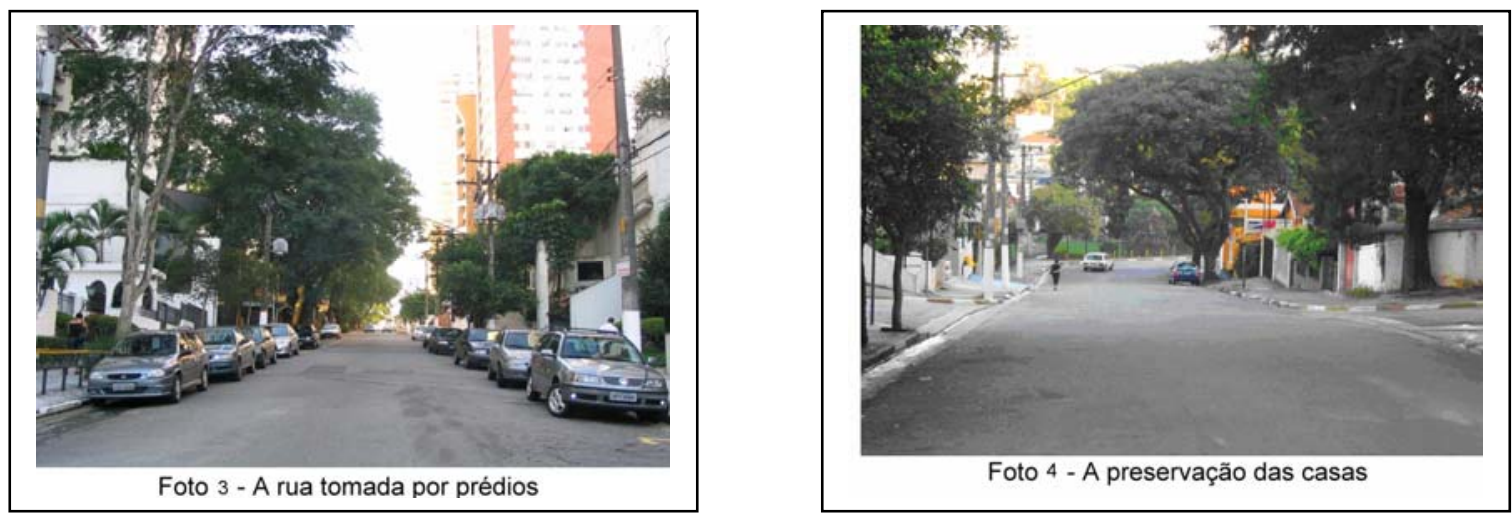

Ao observar a foto 4, pode-se notar, na esquina do lado direito, um muro branco e, na sua frente, um pinheiro. Lembro-me dele desde criança. Eu o considerava um gigante, pois, naquela época, já o admirava por ser mais alto que o prédio onde morava. Na época do ginásio, era sob a sua sombra que eu esperava o ônibus e assim o fiz durante todos os anos que ali vivi.

Foi importante passar pela Vila e tirar as fotos para escrever este capítulo, voltar ao local e rever as marcas da história. Todavia, mesmo assim, há aspectos que passaram despercebidos quando lá estive e só pude observar pelas fotos. Daí a importância do registro visual que nos ajuda a ver o que não pode ser visto, mesmo estando ali. Foi somente com a observação da foto que me dei conta da presença do pinheiro. E então me pego surpreso: "Como pude me esquecer dele!"

Seguindo abaixo, a rua faz uma grande curva. Eu me recordo que, no período das chuvas, corria-se o risco de ocorrer uma enchente nessa baixada, pois ali passava também um pequeno córrego que havia sido canalizado. Recordo-me agora, ao escrever sobre este trecho, que foi exatamente ali que, ao voltar certo dia da escola, um cachorro saiu correndo 
atrás de mim. Costumávamos voltar correndo da escola e, ao passar por ali, uma menina deixou o cachorro escapar da coleira. Que correria! Nesse local, há muitos anos ficava uma frota de táxi formada por fusquinhas verdes. Na lateral deles havia uma faixa quadriculada amarelo e preta ou. Há alguns anos funciona um sacolão nesse local. Em frente dele há uma rua larga e plana onde ficava o sobrado em que morava a Dona Cecília, minha primeira professora. Nessa rua moravam também alguns colegas. E assim, uma lembrança vai puxando a outra...

Depois da curva, a rua apresenta uma outra subida com casas que lá existem desde aquela época. Este era o percurso que fazíamos a pé para irmos a escola. Era o trecho mais difícil, pois além da subida, era a parte em que éramos mais castigados pelo sol, pois não haviam sombras. Um pouco acima morava uma amiga de escola da minha irmã mais velha. Em frente à sua casa havia um enorme paralelepípedo de granito usado como banco. Não sei por que, mas imaginava que debaixo dele viviam muitos ratos. Ao passar por ali notei que o bloco de pedra continuava ali, imóvel, sem se afetar com a passagem do tempo (foto 5). Prosseguindo até o fim, a rua I sabel de Castela desemboca na rua Natingui (foto 6).

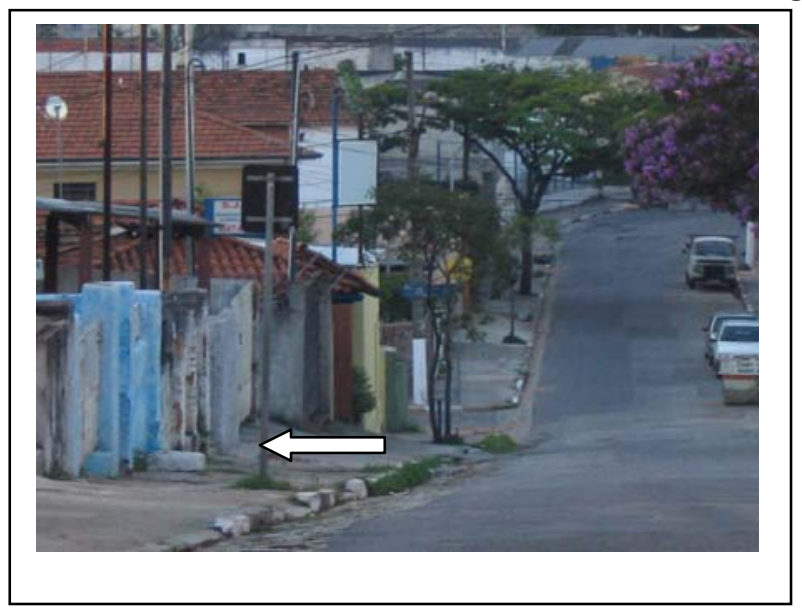

Foto 6 - Esquina da rua Isabel de Castela com a rua Natingui. Do lado esquerdo, escondido pela placa de rua e pelo poste, pode-se ver um resquício da vila: uma antiga casa de comércio, o toldo recolhido, o portão de ferro, o cano de zinco que desce da calha. Ao fundo, contrastando com o velho, se impõe o novo com os altos prédios fechando a paisagem. Do outro lado da rua, atrás do muro azul que sustenta o outdoor vermelho, as casas já foram demolidas.

Foto 5 - A rua Isabel de Castela vista da esquina com a rua Natingui. Este era o caminho de volta da escola. Lá embaixo, na curva, foi onde o cachorro começou a correr atrás de mim. Do lado esquerdo ficava a frota de táxi, hoje o sacolão. Na frente dele, do lado direito de quem olha, ficava a rua onde morava a minha professora.

Um pouco mais acima, do lado esquerdo, pode-se ver um muro azul claro e, abaixo dele, o bloco de pedra, apontado pela seta.

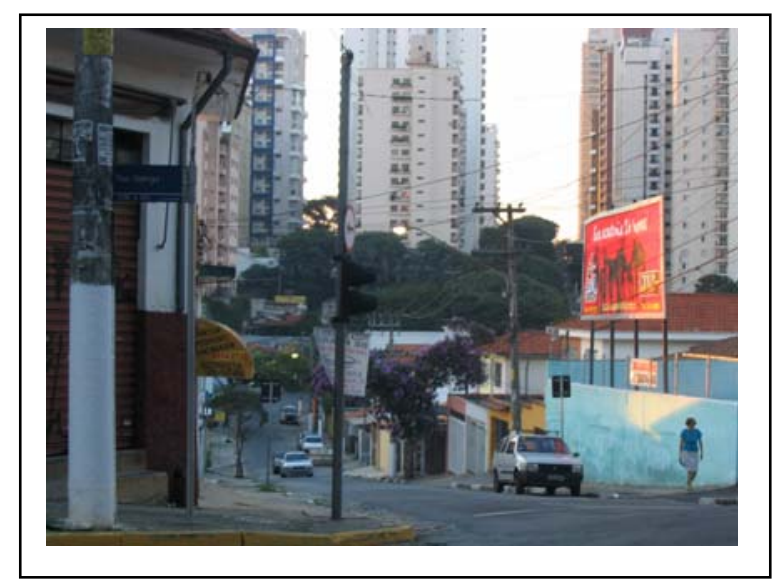


Tanto a rua Isabel de Castela como a rua Natingui hoje servem como corredores que ligam diversas regiões, apresentando um intenso tráfego de veículos.

Uma das coisas que me lembro, quando os altos prédios ainda não

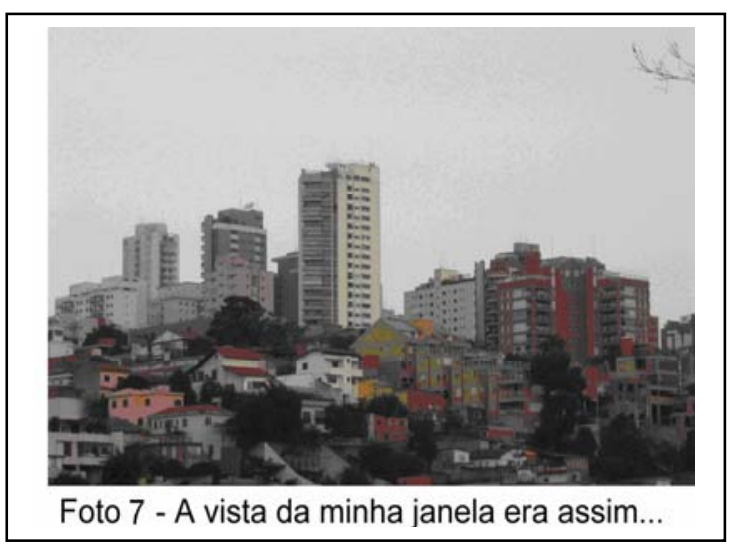
haviam sido construídos, era a vista da janela da sala. Era uma vista esplêndida do bairro, como uma tela de cinema, pois a janela era ampla e tomava praticamente toda a parede. Ao longe via os morros que circundavam toda a paisagem (foto 7) e, quando pequeno, ficava imaginando o que haveria atrás deles. Em certa época, à minha maneira infantil de compreender as coisas, pensava que o mundo terminava ali, margeado pelos morros. E via que no alto deles também existiam edifícios e pensava no medo que as pessoas que lá viviam deviam sentir ao vislumbrarem o abismo do fim do mundo e, lá embaixo, apenas o espaço sideral, cheio de estrelas. Anos mais tarde, ao ampliar meu conhecimento sobre 0 bairro,

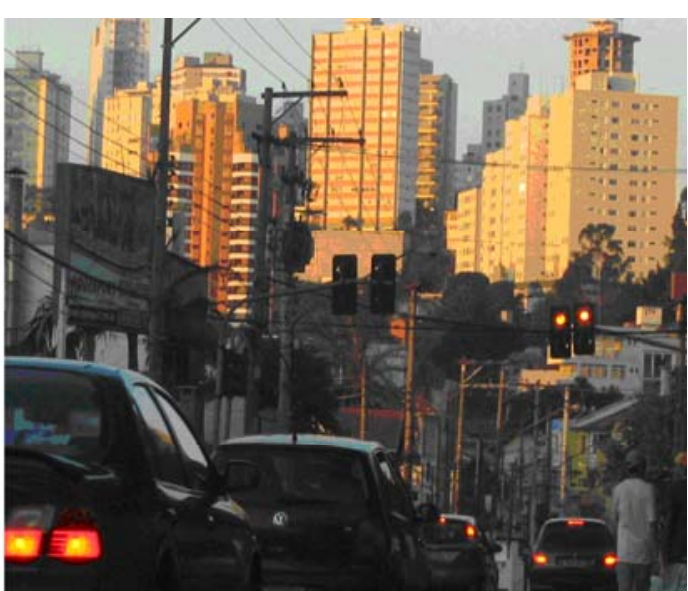

Foto 8 - Os prédios da Heitor Penteado vistos da rua Natingui. pude perceber que 0 mundo não acabava ali e que os prédios que eu avistava ficavam na avenida Heitor Penteado (foto 8). 


\section{O universo social}

Meu primeiro contato social fora da minha família foi com o menino que morava no apartamento em frente ao meu. Era o Marcel. Ele era um ano e meio mais novo que eu, mas já era do meu tamanho. Conta ele que, em nosso primeiro contato, eu usava um chapéu, ou um boné que tinha protetores de orelhas. O Marcel chama até hoje de "chapéu de aviador". Ele conta que eu comia biscoitos de um pacote e que me recusei a lhe dar um. Apesar do evento, fomos companheiros por toda infância e juventude e ainda mantemos contato apesar de não nos vermos mais com tanta freqüência.

Ao lado de nosso prédio havia um imenso terreno baldio que foi ocupado de diversas formas: como pasto para cavalos, com um circo, com

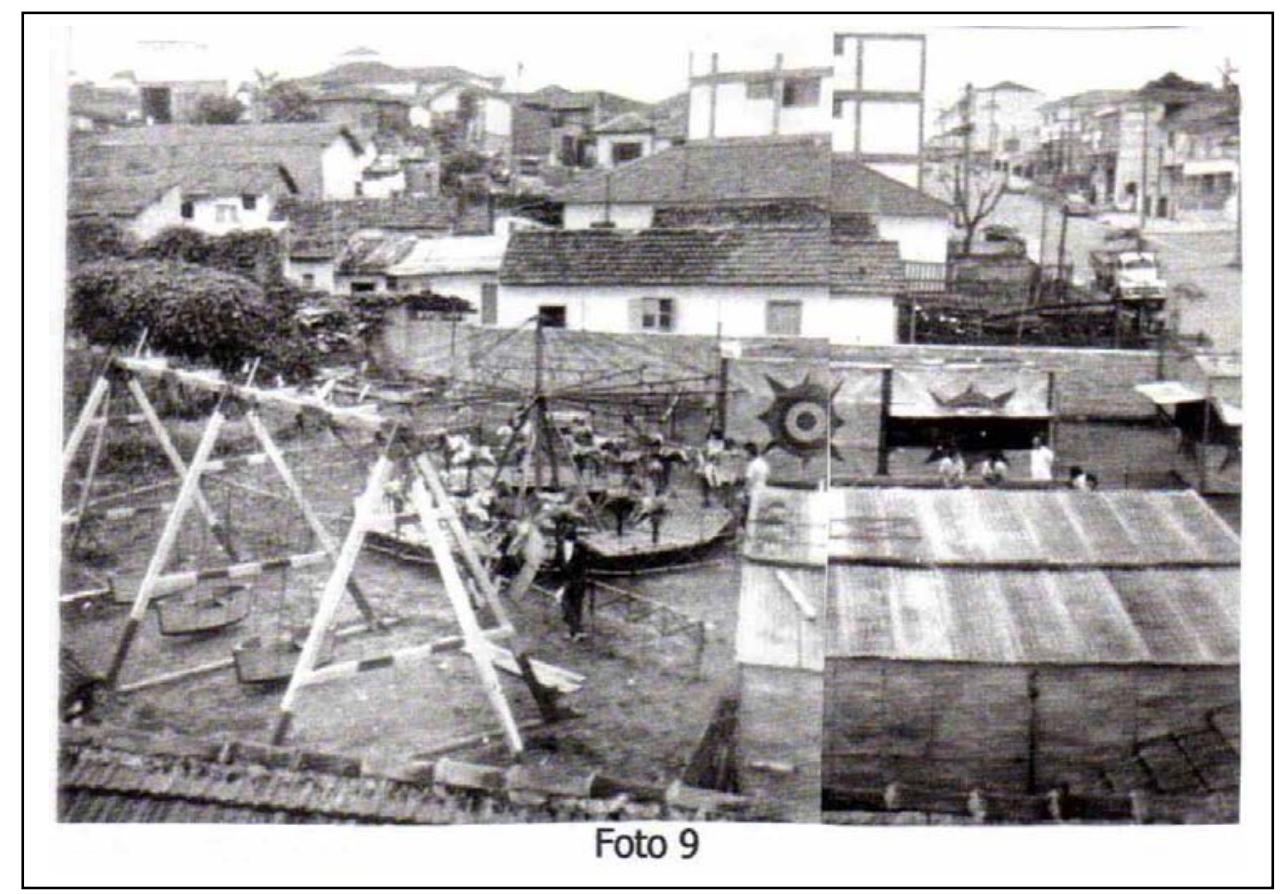

parque de diversões (foto 9), mas ficava a maior parte do tempo vazio, lugar para os moleques brincarem. Eu mesmo fui poucas vezes para lá, apesar de ser ao lado do prédio e poder ser visto de nossa área de serviço, no caso, pela minha mãe. Do outro lado do terreno havia pequenas casas onde viviam muitas famílias pobres, mais propriamente um cortiço. Lá moravam alguns meninos que eram tratados por mim e por Marcel ora como amigos, ora 
como inimigos. Eram principalmente o Tico, seu irmão Luiz e o Pedrinho. Não sei se eram verdadeiramente inimigos ou amigos, mas certamente companheiros de brincadeiras de guerra e, então, faziam o papel de adversários. Talvez ali já se esboçasse a luta de classes.

Muitas vezes brincadeira e realidade se confundiam e acho que nem nós sabíamos ao certo quando estávamos brincando de guerra ou quando a guerra era de verdade. Será que a rivalidade era real e fingíamos que brincávamos ou apenas estendíamos a brincadeira para a vida real? De toda forma, a guerra deu sinais de seu fim nos tempos da escola, quando passei a reduzir o pouco tempo que ficava na rua.

No primário, quando eu estudava na escola do bairro, havia muitos colegas da classe que moravam perto de casa. Alberto morava no mesmo quarteirão. Ficamos amigos e um ia à casa do outro. Acabei ficando amigo também de seus irmãos. Havia também o Francisco, o amigo rico. Era filho único, tinha muitos brinquedos e morava num grande sobrado que ficava na rua transversal à minha. Eu gostava de ir à sua casa porque os lanches eram deliciosos. Na mesma rua, em frente de nosso prédio, morava o Edson e, no terreno ao lado do seu, Jailton e seu irmão, cujo nome já não me lembro mais. Em seu terreno havia uma imensa árvore que eu contemplava da janela da minha sala e toda primavera ela florescia esplendorosamente. Nunca me esquecerei dessa vista. Mas um dia, muitos anos depois, ela não estava mais lá, pois havia sido cortada quando começaram a construção de um imenso prédio no terreno.

Quando mudei de escola, no quarto ano primário, passei a não ver mais os antigos amigos. Além disso, aos poucos, eles foram se mudando, pois o bairro também começava a mudar. As casas foram cedendo lugar aos altos edifícios. Ao lado de nosso prédio, no terreno baldio, levantou-se um enorme edifício de apartamentos - lembro-me até de quando iniciaram o bate-estacas, tudo tremia como um terremoto. As crianças que moravam no cortiço também tiveram que se mudar e não houve nem um aperto de mão na despedida. Simplesmente se foram. 
Lembro-me que entre o terreno baldio e o nosso prédio havia também algumas casas e numa delas morava um garoto chamado Marcelo. Todos o chamavam de louco. Ele era um pouco mais velho que nós, maior, e não ia à escola. Era também estrábico. Ninguém brincava com ele. Nossas mães nos preveniam e nós acabávamos ficando com medo dele. Que fim levou Marcelo?

Por falar em loucos, havia também na vila um homem gordo - na época me parecia enorme - que perambulava sozinho pelas ruas. Também tínhamos medo dele, pois diziam que ele era louco. Pelo que me lembro ele não falava, apenas soltava altos sons guturais. Não parecia muito simpático. Hoje sei que ele não passava de um homem com Síndrome de Down e que Marcelo era apenas uma criança com deficiência mental.

No ginásio conheci novos amigos com quem me encontrava fora do horário de aula. Muitos dos amigos moravam mais próximos do bairro de Pinheiros, mas havia alguns que moravam na vila, como o Eduardo. Foi nessa época que aprendi a andar de bicicleta com Jorge, também amigo da escola, numa rua de ladeira perto de casa. Eu tinha por volta de onze anos e a bicicleta havia ganhado de presente de meu pai. E assim começamos a andar de bicicleta pelo bairro e aos poucos fomos formando uma pequena turma com os meus colegas de escola e os colegas do Marcel. Acho que foi o período que mais fiquei na rua e quando pude me tornar mais moleque.

Hoje posso ver como quase todos os meus amigos, com algumas raras exceções, conheci somente por intermédio da escola. Meu universo social se restringia a escola e a família. Assim foi durante o primário, o ginásio e o colegial. De certo modo, vejo como minha experiência social foi muito restrita e talvez não muito diferente daquela vivida pelos alunos de escola especial. Mas sobre isso retomarei em outro momento.

Quando fui para a escola técnica distanciei-me definitivamente de alguns amigos. A escola era distante e passava bom tempo fora de casa. Meu universo social se ampliava para fora do meu bairro. Conheci muitas pessoas de vários lugares distantes da cidade ao mesmo tempo em que me 
distanciava das pessoas de meu bairro. A propósito, foi nessa época também que minha família mudou-se do apartamento da Vila Beatriz para uma casa na Vila Madalena, restringindo meu circulo social ao espaço privado da minha casa.

Nos anos que ali vivi não estabeleci muitos vínculos sociais. Por um lado, pelo fato de permanecer pouco tempo no bairro e também por não ter dado a devida importância a isso. Por outro, devo considerar também que os vizinhos, assim como eu, não tinham o hábito de conversar uns com os outros. É possível que a própria característica da rua não possibilitasse os encontros, pois era muito movimentada e pouco acolhedora. Os moradores permaneciam a maior parte do tempo dentro de suas próprias casas ou, quem sabe, no trabalho e na escola.

Assim, muitos anos se passaram até começar a perceber que algumas pessoas que conhecia, que moravam em outros bairros, sabiam mais da Vila Madalena do que eu.

\section{“O olho e o espírito" do viajante}

Foi no final da escola técnica que comecei a fazer algumas viagens pelo Brasil e por países da América do Sul. Durante as viagens assumia a condição de viajante, de passageiro, todavia, quando retornei de uma das viagens mais longas que fiz, percebi que a sensação de ser estrangeiro permanecia dentro de mim, mesmo eu estando em meu próprio bairro. Comecei a me dar conta que havia ido a lugares tão distantes, conhecido tantas pessoas diferentes, mas, por outro lado, conhecia tão pouco os meus vizinhos, o meu bairro - lugar onde passei tantos anos, mas por tão pouco tempo. Na condição de estrangeiro em meu próprio lugar, acabei por não criar raízes, estabelecer vínculos, pois tudo era sempre passageiro, transitório.

Com o passar dos anos, quando eu já era adulto, fiz algumas viagens para alguns países da Europa e, aos poucos, o conhecimento desses lugares 
começou a mudar o meu olhar ${ }^{2}$ sobre a minha própria cidade. Mas nessa época eu não vivia mais na Vila Madalena, pois havia voltado a morar na Vila Beatriz.

Durante as viagens eu me encantava com a atmosfera medieval de algumas cidades, com as ruas estreitas, com a arquitetura de suas construções antigas. Aprendi a apreciar os estilos românico, o gótico, 0 renascentista, o barroco. Cada pedra, cada arco, cada coluna, cada detalhe de uma construção era o testemunho de uma época. A história estava presente com suas marcas por toda parte e se misturava ao cotidiano das pessoas. Em Barcelona, por exemplo, todos os períodos históricos estavam presentes, desde a ruína mais antiga do império romano até as obras da vanguarda artística; de um lado a catedral gótica, em outro, a Sagrada Família de Gaudí.

Nessa cidade fazia longas caminhadas pelas ruas, pelas avenidas, pelos bairros, olhando cada detalhe dos prédios, das portas, das janelas e até das fechaduras. E assim, aprendi a fazer também, em meu retorno à Vila Beatriz.

Chamava a minha atenção também a vida comum que se apresentava nas ruas, nas praças ocupadas por diversos tipos de pessoas: crianças, mulheres, jovens, turistas, imigrantes, velhos e deficientes. Lembro-me que foi em Barcelona que vi um grupo de jovens deficientes passeando de bicicleta pela praça. A impressão que eu tinha era a de que a cidade convidava e proporcionava às pessoas a ocupação dos espaços públicos havia lugares para as pessoas estarem, descansarem, se encontrarem, conversarem. 0 espaço público não era apenas um local de passagem, mas servia também para se ficar, permanecer. Além dos espaços abertos havia também os cafés onde as pessoas se encontravam para conversar e

\footnotetext{
${ }^{2}$ Em “O olhar viajante (do etnólogo)", Sérgio Cardoso (1988), tendo Merleau Ponty como referência, faz uma discussão a respeito do olhar, diferenciando-o do ver, pois "o olhar pensa; é a visão feita interrogação"(p.349), assim como pensa a viagem como experiência temporal e não como deslocamento pelo espaço. Estabelece assim uma aproximação entre a experiência do olhar com a experiência da viagem: "verifiquemos então que, assim tomadas, as viagens revelam inequívoco parentesco com a atividade do olhar." (p.358). "As viagens, na verdade, parecem ampliar intensificar e prolongar - o mesmo movimento que cotidianamente verificamos no exercício do olhar...” (p.358)
} 
permanecer além do tempo destinado para se tomar café. Na Inglaterra, por exemplo, chamou-me a atenção os pubs como lugar de encontro. Assim, a impressão que eu tinha era que a vida não se restringia ao espaço privado das casas existindo alternativas nos espaços públicos.

Em 1997, numa passagem rápida por Portugal, conheci uma cidade de fronteira que se chama Guarda. Foi uma sensação estranha e ao mesmo tempo surpreendente descobrir na construção de suas casas tamanha semelhança com as casas da Vila Madalena. Mas espanto maior foi ouvi-los falar português, pois era a primeira vez que pisava em Portugal e estranhava alguém falar o mesmo idioma que o meu em terra tão distante. Pensei ter compreendido o que Caetano Veloso quis dizer com "minha língua é minha pátria". Tudo se juntava para formar um cenário ao mesmo tempo desconhecido, mas, contraditoriamente, familiar. Sentia-me em casa. Era como se, após ter viajado quilômetros pelo espaço geográfico, tivesse encontrado acidentalmente, como Alice do país das maravilhas, um buraco que me levasse diretamente de volta à Vila Madalena, a casa que mal havia habitado ${ }^{3}$. Seria o início de um encontro?

Alguns anos mais tarde, em 2002, retornei à Portugal. Todavia em Lisboa não encontrei a Vila Madalena, mas a rua "Barão de Itapetininga", do centro da cidade de São Paulo. Era a rua Augusta, um calçadão movimentado que fica na parte mais antiga da cidade. Tampouco consegui imaginar Fernando Pessoa ou J osé Saramago caminhando por aquelas ruas e nem pude me imaginar ouvindo a voz de Teresa Salgueiro ${ }^{4}$ cantando ou os

\footnotetext{
${ }^{3}$ Essa experiência possibilitou-me compreender o que Cardoso (1988, pp.359-360) escreveu sobre a viagem: “(...) as viagens, na verdade, nunca transladam o viajante a um meio completamente estranho, nunca o atiram em plena e adversa exterioridade (mesmo porque ele não se encontra "dentro do espaço", como uma coisa, nem "fora dele", como um espírito, como a cada passo insiste em lembrar Merleau-Ponty); mas, marcadas pela interioridade do tempo, alteram e diferenciam seu próprio mundo, tornam-no estranho para si mesmo. Assim, neste sentimento de estranheza, de "alheamento" e distância, seu mundo não se estreita, se abre: não se bloqueia, mas experimenta a vertigem da desestruturação (sempre, em alguma medida, marcada pela perda e a morte) que lhe impõem as alterações do tempo. É desta natureza o estranhamento das viagens: não é nunca relativo a um outro, mas sempre ao próprio viajante: afasta-o de si mesmo, deflagra-se sempre na extensão circunscrita de sua frágil familiaridade, no interior dele próprio. O distanciamento das viagens não desenraiza o sujeito, apenas diferencia seu mundo...quando, é verdade, ele não se mostra demasiadamente compacto - e defendido - para deixar penetrar o tempo".

${ }^{4}$ Vocalista do grupo musical português Madredeus
} 
sons que Wim Wenders ${ }^{5}$ (1994) captou em seu filme "Sob o céu de Lisboa". Estaria eu empedernido pelo espírito do turista que busca apenas 0 estereótipo dos lugares, a certeza do conhecido? Talvez não, mas certamente não foi ainda em Lisboa que eu voltaria a me encontrar com 0 espírito do viajante. Quem sabe a ânsia por encontrar apenas o familiar tenha me impossibilitado ver o que a cidade poderia ter me revelado de inusitado. Foi somente quando meu olhar desistiu da procura é que a beleza da viagem começou a se manifestar, quando eu menos esperava e no lugar em que eu imaginava menos propício para essa descoberta - foi na autoestrada para Coimbra que pude me transportar e começar minha viagem. Lições da arte cavalheiresca do arqueiro zen.

\section{Um outro olhar sobre o bairro}

No início da década de 90, após ter morado em outros bairros, voltei a morar no mesmo apartamento que havia vivido na infância. 0 retorno à Vila Beatriz, após tantos anos, foi muito significativo. Foi a oportunidade que eu esperava, como se fosse a chance de um reencontro comigo mesmo, com a minha história. Mas o bairro estava totalmente mudado. Muitas casas haviam sido demolidas, o entorno havia sido ocupado por altos edifícios e já não restava muita coisa da antiga vila, a não ser o meu prédio e o bar que ficava em frente ${ }^{6}$. Mas mesmo assim, sentia que era o meu lugar. Eu me sentia em casa.

Eu estava atento para cada detalhe, observando cada mudança ocorrida no bairro e no apartamento. De fato, eu exercitava o olhar do viajante.

\footnotetext{
${ }^{5}$ Mais dados sobre o filme podem ser encontrados no site www.wim-wenders.com.

${ }^{6}$ No capítulo intitulado "Os espaços da memória", contido em seu livro "Memória e sociedade”, Ecléa Bosi (1994, p.452) faz um comentário a respeito das mudanças nos bairros: "Destruída a parte de um bairro onde se prendiam lembranças da infância do seu morador, algo de si morre junto com as paredes ruídas, os jardins cimentados. Mas a tristeza do indivíduo não muda o curso das coisas: só o grupo pode resistir e recompor os traços de sua vida passada. Só a inteligência e o trabalho de um grupo (uma sociedade de amigos de bairro, por exemplo) podem reconquistar as coisas preciosas que se perderam, enquanto estas são reconquistáveis. Quando não há essa resistência coletiva os indivíduos se dispersam e são lançados longe, as raízes partidas”.
} 
A propósito, como escrevi anteriormente, foi nesse período que comecei a viajar para a Europa. As viagens me instigaram a vontade de conhecer melhor o lugar em que eu vivia. Talvez eu tivesse aprendido que 0 espírito de viajante proporcionava a mim não somente o sentimento do estrangeiro sem raízes, mas também a prazerosa sensação de estar aberto para conhecer os lugares e as pessoas. Talvez eu tivesse aprendido que poderia prolongar a boa sensação de estar viajando, de poder continuar exercitando o olhar do viajante, mesmo estando em minha cidade. Nessa época, portanto, juntou-se tudo: o entusiasmo do retorno e a experiência do viajante, a "fome com a vontade de comer".

0 que havia aprendido viajando queria praticar no meu lugar ${ }^{7}$. Viver no meu cotidiano com a vontade de conhecer do viajante. Tinha vontade de conhecer as ruas da vila. E assim, aos poucos, fui realizando minhas viagens pelas vilas - não apenas a Vila Beatriz, mas também a Vila Madalena.

Habitualmente fazia caminhadas pelas ruas, mas procurava evitar os mesmos roteiros. Foi realmente um período de descobertas, como se eu estivesse em um país desconhecido. Caminhava com o mesmo espírito e com o mesmo olhar curioso com que caminhava em minhas viagens, olhando a construção das casas, o detalhe das portas, das janelas e das fechaduras. Subia e descia as diversas ladeiras que compõem a paisagem da vila, com suas ruas de nomes tão incomuns: Ourânia, Girassol, Purpurina, Harmonia, Simpatia, Wizard, Córrego das corujas, Praça do Pôr do Sol etc.

Nesse período, pude habitar mais a vila freqüentando, inclusive, a feira de quarta-feira, chegando a ficar conhecido em algumas barracas. Comecei a conhecer também as pessoas que habitualmente corriam na praça perto de casa, o mecânico que vivia consertando o meu Fusca, os taxistas, os vizinhos.

\footnotetext{
7 Em “Olhar e memória” José Moura Gonçalves Filho (1988, pp.103-104) faz uma citação de Merleau-Ponty quanto este discute a experiência etnológica: “A etnologia não é uma especialidade definida por um objeto particular - as sociedades "Primitivas" - , é a maneira de pensar que se impõe quando o objeto é o "outro” e que exige nossa transformação. Assim, também viramos etnólogos de nossa própria sociedade, se tomarmos a distância com relação a ela (...). Método singular: trata-se de aprender a ver o que é nosso como se fossemos estrangeiros, e como se fosse nosso o que é estrangeiro (...)"
} 
Foi um período muito bom e muito importante para mim. Sem dúvida foi um período de encontro e descoberta, daquilo que eu já conhecia e daquilo que eu supunha conhecer.

No ano de 2000 por motivos de ordem pessoal e profissional me despedi novamente da Vila Beatriz e mudei-me para a região do $A B C$. $E$ assim foi dado o início de uma nova jornada, uma nova viagem e novamente a vontade de conhecer.

\section{Das vilas ao ABC: experiências de uma passagem}

Não me recordo de ter vindo a São Bernardo antes do ano de 1989, ano da primeira eleição direta para a presidência. E o ABC mais uma vez era cenário das manifestações políticas. Mas foi somente em 1992 que passei a conhecer melhor a cidade, período em que comecei a trabalhar como psicólogo na educação especial. Contudo, transitava pela cidade na condição de mero passageiro e não mantinha nenhum de vínculo com São Bernardo. Vinha, trabalhava e voltava para o meu bairro.

Em 1994 me despedi da cidade e retornei no ano 2000, novamente por conta do trabalho. A partir dessa data até hoje venho conhecendo um pouco melhor a cidade, mas ainda me esforço para construir um mapa em minha cabeça. Todavia mais importante que isso, venho tentando compreender a dinâmica das relações sociais, a política, a cultura e enfim, 0 modo de ser dos sãobernardenses.

Tive uma boa oportunidade para conhecer a cidade por meio do trabalho na escola especial, quando passei a circular com os alunos pela cidade, conhecendo os bairros onde moravam, as linhas de ônibus e, um pouco melhor, o nome e a localização das regiões, assim como alguns pontos de referência como indústrias, praças, escolas entre outros mais curiosos como a chaminé, o cruzeiro etc.

Anteriormente a minha vinda no ano 2000, mais precisamente em 1998, já vinha para São Bernardo para realizar a Oficina de Fotografia. 
Em 2001 mudei-me para Santo André e assim o centro de gravidade deslocou-se definitivamente para o $A B C$. Mas permanecia um estrangeiro, pois mantinha a minha identidade ainda como morador da Vila Beatriz e da Vila Madalena.

\section{O olhar que interroga: algumas questões sobre a cidade}

Com o passar do tempo procurava encontrar os motivos pelos quais eu percebia tamanha diferença entre a Vila, São Paulo e o $A B C$ e, quem sabe por isso, a sensação de ser estrangeiro. Tudo parecia ter uma dimensão maior, mais gigantesco, mais distante, as avenidas mais largas, a rodovia. Não me sentia acolhido na grandeza do $A B C$, não conhecia os locais que me possibilitariam essa sensação de acolhimento da pequena vila. Será que é assim que os migrantes se sentem ao chegar aqui?

A partir de minha mudança, inevitavelmente, passei a estabelecer comparações entre o lugar onde eu vivia e o lugar em que passei a viver. Sentia falta de muitas coisas com as quais eu havia me habituado e com as quais me identificava. Por outro lado, não me identificava com muitas coisas que encontrava na região, pressentindo certo incômodo, cuja causa eu mesmo desconhecia. Penso que esta mudança para a região apurou o meu olhar crítico, agora não mais como um passageiro e sim como morador. Foi também com a mudança que passei a olhar a Vila com outros olhos, tomando a consciência de meu sentimento de pertencimento somente por conta da minha sensação de exílio.

São Bernardo apresentava contrastes, polaridades que fui descobrindo somente quando o olhar atravessou a superfície do mapa geográfico e assumiu uma postura mais questionadora.

Como me referi anteriormente, a cidade causava certo impacto pelas dimensões que apresentava. Tudo parecia muito grande e quanto mais sua estrutura parecia se agigantar, mais parecia acentuar a pequenez dos indivíduos. 


\section{CAPÍTULO III}

\section{A PESQUI SA}

\section{Parte I - Sobre o método}

\section{Algumas reflexões acerca do método}

Elaborar uma tese é como confeccionar um objeto artesanal. Comparo sua redação como, por exemplo, a confecção de um tapete de linhas ou uma colcha de retalhos ${ }^{1}$. Neste caso, penso que a melhor comparação é com a segunda, pois suponho, embora nunca tenha sequer feito uma colcha e muito menos um tapete de linhas, que a confecção de um tapete segue uma linearidade, uma seqüência variável ou não, mas contínua de pontos como o tricô ou crochê, muito diferentemente de como vem ocorrendo nesta tese. Por isso vejo que a idéia da colcha se aproxima mais deste caso: pedaços que vão se constituindo simultaneamente, paralelamente e vão se juntando em partes maiores até formar a colcha.

Em muitos momentos vou emendando intuitivamente os pedaços, sem poder prever exatamente onde se vai chegar, pois o desenho e a forma vão se constituindo durante o fazer. Às vezes, algumas peças ficam de fora, outras vezes é necessário até desmanchar alguns pedaços, corrigir e recomeçar.

Para se elaborar uma tese é necessária uma elaboração intelectual, um planejamento, um método, mas também a intuição, pois ela é um importante instrumento que pode nos orientar no momento de juntar os pequenos retalhos. Segundo Bernadete Gatti (1999, p.76) “O pesquisador se

\footnotetext{
${ }^{1}$ Depois de ter redigido este pequeno trecho sobre o método, tive uma surpresa ao ler a tese de Doutorado de Maria Eloísa M. D'Antino (2001) intitulada "Deficiência e a mensagem reveladora da instituição especializada: dimensões imagética e textual”, na qual ela cita Adorno quando este faz um comentário sobre o ensaio como forma de expressão do pensamento, comparando-o a confecção de um tapete. Outra surpresa foi encontrar na tese de Livre Docência de Lígia Assumpção Amaral Deficiência, Vida e Arte - a imagem de um jacquart para se referir ao modo como vinha elaborando suas idéias, como "uma complexa trama” (1998a, p.12). São imagens que, sem perceber, havia tomado como minhas e delas me apropriado para me referir ao modo como via a elaboração da minha tese.
} 
utiliza muito da intuição e da imaginação. Não é apenas a lógica a grande arma do pesquisador. No ato de pesquisar ela se associa fortemente com a intuição e a imaginação" Assim, a figura que vai sendo composta pelas partes vai também se constituindo intuitivamente em nossas cabeças sem, necessariamente, nos darmos conta disso.

Então a tese é uma colcha de retalhos? Penso que sim, porque, depois de pronta, não se vê apenas um amontoado de retalhos, mas pedaços ordenados que configuram uma nova unidade. Assim, uma peça quando acabada, inteira, inaugura um novo sentido. Nessa perspectiva, o todo pode ser visto diferentemente de uma mera e aleatória junção de partes.

O olhar analítico decompõe o todo e insiste em não deixar de focar as partes, os retalhos, as costuras que as unem, mas se esquece que, unidos, eles inauguraram um novo objeto, uma outra singularidade; um todo diferente de qualquer outro até então composto, um todo nunca visto, inédito.

Todavia, diferentemente do olhar analítico, o olhar pode ser também um olhar mais generoso, mais amplo, que permite se desfocar do detalhe da parte e se perder; um olhar que proporciona o espanto diante da beleza inusitada que se deixou surgir da nova figura que foi composta. Por fim, após a emergência do novo sentido, esse olhar autoriza ainda a atribuição de um outro nome, diferente de retalho, ao que surgiu e autentica essa coisa até então inexistente: a colcha.

Penso nesta tese desse modo, como uma colcha que vai se constituindo pelas partes, mas cada parte que se junta às demais pode sempre revelar um novo significado. Este, por sua vez, não está necessariamente previsto no início da trajetória que, tampouco, segue uma seqüência ou planejamento linear. As partes da colcha (problematização, metodologia, fundamentação teórica, coleta de dados) vão ocorrendo simultaneamente, uma se iniciando e se desenvolvendo sem que a outra, necessariamente, esteja finalizada. Assim, cada parte ao se constituir vai interferindo na constituição da outra. 
Vejo que uma tese é, de certa forma, uma peça artesanal porque sempre resulta em uma peça singular, ainda que possam existir muitas semelhanças com outras peças. Diferentemente da peça manufaturada em série, que anula a presença da singularidade - pois as cópias são idênticas -, a peça artesanal, ao contrário, revela a presença do artesão.

Em um tempo em que os objetos de consumo são reproduzidos em alta velocidade, confeccionar artesanalmente uma colcha, ou melhor, uma tese, parece um tanto anacrônico para os dias de hoje. A singularidade que caracteriza a produção artesanal passa a ser desnecessária e dispensável porque demanda muito tempo e porque, afinal, até a singularidade de uma obra de arte pode ser imitada e copiada pela máquina, tal como discutiu Benjamin em seu texto "A obra de arte na era de sua reprodutibilidade técnica".

De toda forma, a confecção de uma peça artesanal ou de uma tese sempre solicita certo domínio da técnica, pois não são realizadas totalmente por ensaio e erro:

Um bom martelo, uma boa pá são absolutamente necessários para um trabalho de qualidade, mas, também, necessita-se de um artesão habilidoso e experiente em seu uso para obtenção de resultados qualitativamente bons. Apenas uma boa pá nas mãos de quem não desenvolveu competência e não tem uma perspectiva para seu uso não garante um bom resultado" (Gatti, 1999, p.71).

Assim, sempre se parte do conhecimento e da experiência anteriormente acumulados. E este é um aspecto interessante. Quanto menor a experiência de um artesão, menor a chance de repetir o mesmo caminho e reproduzir peças semelhantes. Nesse caso, a originalidade se apresenta como imperfeição e valorada negativamente, pois denota a incapacidade de repetição do mesmo. Na medida em que a experiência vai se acumulando, o artesão aperfeiçoa as fórmulas e técnicas que lhe possibilitam a repetição. Quanto menor o domínio e a experiência, maior a necessidade de atenção e 
reflexão e maior a chance da surpresa diante daquilo que surge como inesperado. Todavia, não podemos deixar de considerar que o domínio da técnica pode levar também à inovação, mas, nesse caso, mesmo o experiente artesão se coloca novamente na condição do aprendiz porque não sabe necessariamente o resultado que surgirá, estando sujeito, assim como o aprendiz, à surpresa e ao inesperado. Não quero deixar a impressão de que se trata de uma pesquisa totalmente caótica, tal como um bolo sem receita sendo feito por um aprendiz, embora eu saiba que posso ter ajudado a passar essa idéia ao leitor.

A pesquisa tem seus pontos de origem bem demarcados: a minha experiência profissional como psicólogo da educação especial, a dissertação de mestrado e a própria reflexão sobre minhas experiências escolares.

De modo geral, esta pesquisa não deixa de ser um questionamento sobre nossa contemporaneidade, sobre nosso tempo e sobre o modo como nós, habitantes das cidades, seres urbanos, temos construído, mantido e reinventado nossa relação com o lugar onde vivemos. Seria uma grande, ampla e pretensiosa interrogação se não houvesse a delimitação devida, tal como exposto no momento da problematização.

Embora os marcos fundantes da pesquisa estejam claros, entendo-os como aspectos macro ou idéias gerais e norteadoras. Os pequenos detalhes - o que chama de retalhos - vem sendo descobertos a cada passo, a cada leitura realizada, a cada orientação recebida, a cada contato com os participantes, a cada linha que escrevo - cada detalhe que, em sua descoberta, possibilita uma re-elaboração do já existente ou ainda uma resignificação do que já se pensava como conhecido, revelando um novo sentido possível - saber de um novo jeito o que já se sabia sabido. E isso para mim tem sido muito curioso e gratificante, pois é como se, de repente, num esbarrão não intencional, me encontrasse com algo que sempre esteve ali, visto, mas, por incrível que pareça, não percebido. Assim, parece maior a surpresa; não é a descoberta do que estava oculto, mas o espanto diante daquilo que já se pensava conhecido. 
Neste momento da redação despertou-me um novo sentido, sintetizado em uma imagem: a teia de aranha. Uma construção não linear, mas em forma de rede espiralada, que se tece sustentada nos raios concêntricos e que tem como finalidade a captura da presa. Cada teia é construída e adequada a uma gama restrita de presas, não muito grandes e nem muito pequenas. Penso que assim deve ser o método. Mas, afinal, qual a presa que pretendo capturar ${ }^{2}$ ?

\section{Em busca de referenciais teórico-metodológicos para pensar sobre o método}

Como foi abordada anteriormente, a pesquisa não partiu de uma abordagem metodológica pré-definida, mas a cada passo ela foi sendo pensada e discutida nos encontros realizados com a orientadora da pesquisa. 0 que se pode perceber é que alguns aspectos metodológicos foram ficando mais claros na medida em que a proposta da pesquisa ia tomando forma e corpo.

Em seu texto intitulado "Algumas considerações sobre procedimentos metodológicos nas pesquisas educacionais", Gatti (1999, p.77) escreve exatamente sobre isso:

O método não é um roteiro fixo, é uma referência. Ele, de fato, é construído na prática, no exercício do "fazer pesquisa". O método, nesse sentido, está sempre em construção.

A autora procura mostrar em seu texto que o método é algo concreto, que se constrói no próprio processo de investigação. Deve ser considerado como um ato vivo e que "se revela nas nossas ações, na nossa organização e

\footnotetext{
${ }^{2}$ Ao brincar com as imagens e os sentidos figurados vejo outras coincidências também com o texto de Bernardete Gatti (1999). Ela escreve "O pesquisador pode ser comparado a um caçador ou a um pescador. Precisa ter todos os sentidos aguçados, não só a sua mente, agindo sob o comando de um bom conhecimento de sua virtual "presa" e do contexto onde vive. A pesquisa é um cerco em torno de um problema. É necessário escolher instrumentos para acessar a questão, vislumbrar e escolher trilhas a seguir e modos de se comportar nessas trilhas, criar alternativas de ação para eventuais surpresas, criar armadilhas para capturar respostas significativas” (1999, p.77).
} 
no desenvolvimento do trabalho de pesquisa, na maneira como olhamos as coisas do mundo" (Gatti, 1999, p.63). A autora escreve ainda:

A colocação dos problemas de investigação é reveladora da perspectiva de abordagem do pesquisador e determinante para seu método. Na abordagem do tema e no enunciado dos problemas revela-se um modo particular de entender e enfocar determinadas questões. A abordagem e o método revelam-se nas formas de pensar e de fazer no transcorrer da própria pesquisa e não por declarações abstratas de adesão a esta ou aquela perspectiva (1999, p.76).

A partir do objetivo estabelecido na pesquisa, seria necessário se pensar numa abordagem que possibilitasse a apreensão e a compreensão do ponto de vista dos sujeitos participantes da pesquisa, assim como os sentidos e significados que atribuem ao bairro onde moram e às experiências realizadas nesses locais, enfim, uma abordagem que propiciasse a visualização das relações que estes sujeitos mantém com o contexto onde vivem; um modo de pesquisa em que o pesquisador não procure se posicionar como um observador imparcial, mas que interaja com os participantes e que sua subjetividade possa ser considerada dentro do universo da pesquisa; uma abordagem em que não se privilegie apenas a comprovação de hipóteses, resultados, mas o próprio caminhar da pesquisa e a possibilidade de revisão dos rumos estabelecidos inicialmente.

Desse modo, pelos passos dados até este momento e pelas características apresentadas, qual seria a metodologia mais adequada?

\section{A abordagem qualitativa}

A discussão sobre a diferenciação entre as duas abordagens não é tão simples como se pode supor e mais, talvez desnecessária ou algo que deva ser superada. Para André, por exemplo, (1992, p.20), a dicotomia qualitativo-quantitativo precisa ser superada e se e buscar respostas para 
outras questões relacionadas ao trabalho científico como critérios para se julgar uma pesquisa, a validade e a confiabilidade, a problemática da generalização, a subjetividade os modos de análise dos dados qualitativos. Além disso, a autora aponta que o próprio termo "pesquisa qualitativa" é muito genérico e permite diferentes concepções. Desse modo, André entende que os termos quantitativo e qualitativo deveriam ser usados para "diferenciar técnicas de coleta ou, até melhor, para designar o tipo de dado obtido" (1992, p.19).

Alguns autores como Martins e Bicudo (1994) e Forghieri (2002) estabelecem algumas diferenciações entre as duas abordagens a partir das concepções que as originaram. Segundo os autores, a pesquisa quantitativa tem sua origem no Empirismo e no Positivismo, enquanto que a pesquisa qualitativa se origina na fenomenologia. André (1992, p.18) vai além, chegando a afirmar que para alguns, como Martins e Bicudo (1989), "a "pesquisa qualitativa" é a pesquisa fenomenológica". De toda forma, o que parece que não se pode negar, no meu entender, é que as duas abordagens partem de diferentes pressupostos que levam a procedimentos diversos e concepções diferenciadas sobre o modo de produzir conhecimento.

André aponta ainda que o termo qualitativo serviu até determinado momento para "identificar uma perspectiva de conhecimento que se contrapunha ao positivismo" (1992, p.19), todavia entende que esse momento parece estar superado, embora não negue a importância que 0 debate teve principalmente por colocar em questão o valor da orientação positivista no trabalho científico (1992, p.20).

Para Martins e Bicudo (1994) a pesquisa qualitativa se caracteriza como um estudo que lida com fenômenos, diferenciando-se da pesquisa quantitativa que trabalha com fatos.

A origem do significado de fenômeno vem da expressão grega fainomenon, derivada do verbo fainestai que significa mostrar-se a si mesmo. Desse modo, "a expressão fenômeno tem o significado de aquilo que se mostra em si mesmo, o manifesto" (Martins e Bicudo, 1994, p.22). Os 
autores contam também que os gregos identificavam os fainonema como ta onta que significa entidades. Esta por sua vez, "pode mostrar-se a si mesma de várias formas, dependendo, em cada caso, do acesso que se tem a ela" (1994, p.22). Nessa perspectiva, abrem-se várias possibilidades de acesso ao fenômeno a ser compreendido, implicando, dessa forma, numa mudança de concepção em relação ao método.

A fenomenologia abre também uma outra possibilidade do homem situar-se no mundo, sair de sua atitude natural, não refletida, para uma atitude reflexiva na qual toma consciência dos significados que atribui à sua existência. Isto não quer dizer, todavia, que a fenomenologia proponha uma negação da vida cotidiana, pelo contrário, propõe o mundo vivido como ponto de partida para a reflexão. É no mundo vivido que os fenômenos se mostram.

Desse modo, a fenomenologia indica que, para se realizar o estudo de determinado fenômeno, este não pode ser compreendido isolado de seu contexto, com as variáveis controladas, pois o "fenômeno mostra-se a si mesmo, situando-se" (Martins e Bicudo, 1994, p.22).

Para Forghieri, a abordagem fenomenológica, ao propor o retorno ao mundo da vida, possibilita o estudo das vivências dos sujeitos inseridos no mundo, em determinadas situações; possibilita a compreensão dos sentidos e dos significados das vivências experienciadas pelas pessoas em seu existir cotidiano.

André (1992, p.11) demonstra compartilhar do mesmo olhar sobre a fenomenologia:

A fenomenologia enfatiza os aspectos subjetivos do comportamento humano e preconiza que é preciso penetrar no universo conceitual dos sujeitos para poder entender como e que tipo de sentido eles dão aos acontecimentos e às interações sociais que ocorrem em sua vida diária. 0 mundo do sujeito, as suas experiências cotidianas e os significados atribuídos às mesmas são, portanto, os núcleos de atenção da fenomenologia. 
Como se pode ver, a particularidade das experiências vividas, na abordagem qualitativa se torna o foco da atenção do pesquisador:

Uma idéia mais geral sobre tal pesquisa é que ela não se preocupa com generalizações, princípios e leis. A generalização é abandonada e o foco da sua atenção é centralizado no específico, no peculiar, no individual, almejando sempre a compreensão e não a explicação dos fenômenos estudados" (Martins e Bicudo, 1994, p.23, grifo nosso)

Como foi mostrado anteriormente, nesse processo de compreensão da vivência das pessoas, o pesquisador não deve se anular, mas voltar também o olhar para si:

Ao se utilizar da redução fenomenológica para investigar formas concretas de existência, ou experiências vividas em determinadas situações, $\underline{0}$ pesquisador deve iniciar o seu trabalho voltando-se para a sua própria vivência a fim de refletir sobre ela para captar o significado da mesma em sua existência" (Forghieri, 2002, p.59, grifo nosso).

Forghieri aponta que a redução fenomenológica, no campo da Psicologia, apresenta dois momentos distintos, embora, como escreve a autora, paradoxalmente inter-relacionados e reversíveis. A autora se refere ao que denomina como "envolvimento existencial" e "distanciamento reflexivo". Sobre o "envolvimento existencial ${ }^{3 "}$ há um aspecto que me chamou a atenção e que gostaria de destacar:

(...) o pesquisador precisa iniciar seu trabalho procurando sair de uma atitude intelectualizada para se soltar ao fluir de sua própria vivência, nela

\footnotetext{
${ }^{3}$ Dentre as características da abordagem qualitativa, este é um dos aspectos que mais me chamou a atenção e me levou a identificar a pesquisa nessa abordagem. Desde o início da pesquisa tenho estado atento ao modo como as minhas próprias vivências, sejam elas pessoais ou profissionais, estavam implicadas na elaboração do problema de pesquisa. A proposta desde o início não era partir de uma formulação intelectual, mas partir da observação de minhas próprias experiências, do mundo vivido que deveria ser interrogado.
} 
penetrando de modo espontâneo e profundo, para deixar surgir a intuição, percepção, sentimentos e sensações que brotam numa totalidade, proporcionando-Ihe uma compreensão global, intuitiva, pré-reflexiva, dessa vivência" (2002, p.60).

Quanto ao "distanciamento reflexivo" a autora coloca que ele ocorre após o envolvimento existencial. Nesse momento o pesquisador deve procurar distanciar-se para poder refletir sobre a vivência, analisa-la e enunciar descritivamente os significados, ou 0 sentido, captados intuitivamente, durante o envolvimento (Forghieri, 2002, p. 62).

Para finalizar esta parte, gostaria de retomar resumidamente alguns aspectos que considerei importantes na abordagem qualitativa:

1. O sujeito e o objeto estão implicados e se revelam mutuamente através da intencionalidade;

2. O conhecimento ocorre sempre situado em um contexto, sendo que o sentido é atribuído a partir dele;

3. Não há uma preocupação com a busca de generalizações, leis e regras, pois o foco se centra no que é particular, específico e individual;

4. O mundo vivido é o ponto de partida das reflexões e o conhecimento não parte das intelectualizações, mas do que é primeiramente vivido, intuído e percebido.

Como pode ser demonstrado, a abordagem qualitativa, em virtude das características apresentadas, foi considerada a mais apropriada para se buscar responder as indagações levantadas nesta pesquisa.

No decorrer da pesquisa, ao realizar o levantamento bibliográfico, deparei-me com algumas pesquisas caracterizadas como estudo etnográfico. Pude notar algumas semelhanças entre a abordagem fenomenológica e 0 estudo etnográfico como, por exemplo, a ênfase nos significados dados pelos sujeitos em suas vivências. 
Ao entrar em contato com a tese de Livre Docência de Marli André (1992), pude compreender o motivo pelo qual eu percebia uma possível aproximação entre a fenomenologia e o estudo etnográfico. Segundo a autora, a fenomenologia dá origem à abordagem qualitativa de pesquisa, “onde também estão presentes as idéias do interacionismo simbólico, da etnometodologia e da etnografia, todas elas derivadas da fenomenologia" (1992:11).

Em relação à etnografia, André (1992) mostra que se trata de uma vertente da antropologia que busca compreender o significado que as pessoas dão às ações e aos eventos. Sato e Souza (2001, p.30), baseandose em Rockwell (1986), mostram, mais precisamente, que a etnografia originou-se na Antropologia Social, sendo utilizada também na Sociologia de tradição inglesa. Etimologicamente pode ser compreendida como "descrição cultural"; pode ser entendida também como um conjunto de técnicas para coletar dados sobre valores, hábitos, crenças e comportamentos de um determinado grupo social e como relato escrito produzido pelo emprego dessas técnicas (André,1992, p.21).

André (1992) aponta para algumas diferenças entre a etnografia, quando utilizada para o estudo da cultura e da sociedade, e quando esta passa a ser usada para pesquisa em educação. A diferença no enfoque faz com que certos requisitos da etnografia não necessitem ser cumpridos quando a investigação se der no campo educacional como, por exemplo, "a longa permanência do pesquisador em campo, o contato com outras culturas e o uso de amplas categorias sociais na análise dos dados" (1992, p.22). Sobre o tempo de permanência do pesquisador no campo, Sato e Souza (2001) apontam que na pesquisa etnográfica o trabalho de campo é extensivo e não intensivo, pois os acontecimentos e os significados somente surgirão com o tempo. Ainda sobre o tempo no campo as autoras escrevem:

A pesquisa etnográfica também nos leva a considerar que será o tempo de convivência o meio pelo qual as particularidades, os jeitos de ser, os modos de representar poderão ser expressos de maneira a dificultar que as 
pessoas exibam apenas aquilo que avaliam que o pesquisador deve ou quer escutar, possibilitando, então desvelar processos criados pelas pessoas em sua vida diária (Sato e Souza, 2001, p.45).

Em outro artigo, Souza (1997) volta a se referir à questão do tempo de permanência do pesquisador no campo, desta vez, explicitamente sobre a escola. Relata que, na referida pesquisa sobre a produção do fracasso escolar, conviveu durante aproximadamente dois anos em uma escola pública da periferia da cidade de São Paulo.

De toda forma, segundo André (1992), como nem todos os requisitos da etnografia são cumpridos em pesquisas na educação, ela entende que seria mais adequado denominar essas pesquisas como estudos do tipo etnográfico e não como pesquisas etnográficas.

\section{A pesquisa de tipo etnográfico}

Para André, o uso de algumas técnicas usadas na etnografia como a observação participante, a entrevista intensiva e a análise de documentos pode caracterizar um estudo como do tipo etnográfico em educação.

Sobre a observação participante, um dos requisitos nesse tipo de pesquisa, André explica que esta parte do "princípio que o pesquisador tem sempre um grau de interação com a situação estudada, afetando-a e sendo afetada por ela" (1992, p.22).

André (1992, pp.22-24, 1995, pp.28-30) aponta para sete princípios que caracterizam a pesquisa do tipo etnográfico:

1. Interação constante entre o pesquisador e o objeto pesquisado;

2. O pesquisador é o principal instrumento na coleta de dados. Os dados são mediados pelo instrumento humano que responde ativamente às circunstâncias, modificando as técnicas de coleta, se necessário, revendo as questões que orientam a pesquisa, revendo a metodologia; 
3. Ênfase no processo e não no produto ou no resultado final;

4. Preocupação com o significado dado pelas pessoas às suas experiências. 0 pesquisador deve tentar compreender o ponto de vista dos participantes;

5. Geralmente envolve um trabalho de campo;

6. Descrição e indução;

7. Formulação de hipóteses, conceitos, abstrações, teorias e não sua testagem. Faz parte ainda o uso de um plano de trabalho aberto e flexível, onde os focos de investigação podem ser revistos.

Ao relatar sobre as qualidades necessárias ao pesquisador que opta por trabalhar nessa abordagem - como tolerância à ambigüidade, sensibilidade, empatia e habilidade de expressão escrita - André explicita ainda algumas outras características da pesquisa etnográfica como a presença de dúvidas, incertezas e inexistência de normas prontas decorrente da estrutura aberta e flexível. A autora escreve ainda que "as decisões sobre como analisar e apresentar os dados também não podem ser predeterminadas, a não ser em linhas bem gerais" (André, 1995, p.60) (grifo nosso).

Baseando-me na bibliografia apresentada, é possível observar que 0 presente estudo caracteriza-se como um estudo de abordagem qualitativa, tendo como referência a pesquisa de tipo etnográfica. Entendo ser importante destacar este detalhe, partindo da observação realizada por André, em virtude do tempo de permanência no campo proposta por esta pesquisa, pois não terei um tempo longo de permanência, tal como solicitam as pesquisas etnográficas. 0 tempo de permanência no local (bairro dos participantes) será restrito a alguns curtos períodos (horas) para realização das gravações. 


\section{As imagens visuais na pesquisa etnográfica}

O presente estudo inspira-se na pesquisa de tipo etnográfico, tal como foi esclarecido anteriormente. Como pode ser visto também, a etnografia é compreendida como "descrição cultural" e, nesse tipo de pesquisa, o registro escrito tem ocupado lugar predominante. Feldman-Bianco (1998) discute exatamente a tradicional predominância do registro escrito, propondo uma reflexão sobre o que denomina como etnografia visual. Em seu texto a autora propõe uma discussão sobre a relevância da documentação visual e também uma discussão sobre as relações entre o texto etnográfico escrito e a etnografia visual.

O uso do vídeo, assim como outros meios visuais, vem crescendo desde a década de 1980 nas pesquisas antropológicas e sociológicas (Feldman-Bianco, 1998, p.11; Leite, 1998, p.38). Todavia, o emprego dos recursos visuais tem suas origens em tempos bem mais remotos, podendo ser citado, por exemplo, o trabalho de John Collier Jr. (1975), conhecido como aquele que utilizou pela primeira vez o termo "antropologia visual". Tacca (1990) apresenta em sua dissertação de mestrado outros exemplos de antropólogos que já faziam uso dos recursos visuais como Franz Boas, Margaret Mead e Gregory Bateson entre outros.

Em sua dissertação, Tacca (1990) discute também o modo como os recursos visuais podem ser utilizados na coleta de dados, apontando duas perspectivas:

1. O olhar de fora da cultura: ocorre quando o registro é realizado pelo pesquisador que não pertence ao grupo estudado. Para Tacca, o olhar de fora da cultura não representa o imaginário da cultura estudada, implicando em recortes e elementos atravessados pela cultura do pesquisador;

2. O olhar de dentro da cultura: o registro é feito por alguém do próprio grupo. 
Sobre a segunda perspectiva, na qual se insere a pesquisa de Tacca, ele cita o trabalho de alguns antropólogos (Sol Worth e John Adair) que ensinaram técnicas de filmagens aos nativos de uma reserva indígena Navaho para que eles mesmos pudessem realizar registros de seu cotidiano.

Tacca (1990, p.45) comenta ainda a opinião desses antropólogos:

Esses autores concordam com Mead e Collier, no que diz respeito às potencialidades cognitivas da visualidade dos meios (fotografia e cinema) na compreensão de aspectos inatingíveis pela abordagem verbal, entretanto, perscrutam uma possibilidade extremamente rica que abriu à pesquisa em antropologia a porta de entrada para o imaginário visual, de dentro do olhar de uma cultura.

Embora o uso dos recursos visuais venha crescendo nas pesquisas em Antropologia e Ciências Sociais, pude observar que o mesmo não vem ocorrendo na Psicologia. Existem alguns pesquisas, mas estão mais voltados para o estudo do desenvolvimento e do comportamento. Um dos trabalhos que pode ser citado é o de Carvalho (1996) intitulado "Registro em vídeo na pesquisa em psicologia: reflexões a partir de relatos de experiência". Tratase de um artigo de periódico em que alguns pesquisadores discutem a utilização do vídeo em estudos sobre o desenvolvimento de crianças enfocando o processo de registro, transcrição e análise. Sobre a análise do material de vídeo há o registro de uma mesa redonda sobre este tema, organizada pelo Conselho Regional de Psicologia em 1998. Todavia, tanto a expositora, como o debatedor, privilegiam a análise do conteúdo verbal contida no material, no caso, um vídeo produzido pelo Conselho Regional de Psicologia sobre a Psicologia como profissão.

Sobre o uso do vídeo em pesquisa de Psicologia com abordagem etnográfica, pude encontrar o estudo realizado por Luchesi (2003). Trata-se de uma tese de doutorado intitulada "Intersubjetividade e diferença : um estudo do contato com pessoas surdas". O estudo relata o contato que a pesquisadora teve com pessoas surdas na Associação de Surdos de São 
Paulo. Os dados analisados foram provenientes do diário de campo e dos depoimentos gravados em vídeo.

Em minha pesquisa de mestrado (Kohatsu, 1999), procurei captar 0 olhar de dentro da cultura através das fotografias realizadas pelos participantes sobre seus respectivos universos sócio culturais. Realizei também uma discussão sobre o emprego dos recursos visuais, mais especificamente o uso da fotografia na pesquisa.

Naquele período, pude encontrar uma pesquisa em Psicologia em que a autora se propôs estudar o olhar dos próprios sujeitos. Refiro-me à dissertação de mestrado de Pesaro (1997) intitulada "Identidade e fotografia: reflexões sobre uma experiência junto a um grupo de pacientes psicquiátricos".

Há também a tese de doutorado de Psicologia que gostaria de citar em que a autora estuda a produção artística de pessoas com deficiência. $\mathrm{Na}$ tese, publicada com o título "Armazém de imagens", Reily (2001) dedica-se ao estudo de Frederico, um rapaz que apresenta notável habilidade artística, mesmo apresentando uma deficiência múltipla. A pesquisa aborda uma outra gama de imagens visuais, como o desenho e a pintura, não se propondo a investigação do uso de recursos visuais como a fotografia e o vídeo, como aqui venho discutindo. De toda forma, penso que seja válida a citação pela relevância da pesquisa.

Gostaria, agora, de apresentar algumas reflexões respeito do uso do vídeo.

\section{Algumas considerações acerca da utilização de imagens na pesquisa}

A fotografia, o cinema e o vídeo, diferentemente de outras formas de representação humana até então conhecidas como a pintura, a gravura e 0 desenho - para citar apenas aquelas em que a representação se dá no plano bidimensional - possuem o poder de fascinar o receptor devido ao fato de 
conseguirem produzir imagens com tamanha fidelidade que chegam a fazer crer que são mais reais do que o próprio referente. Este é o aspecto ideológico, decorrente da técnica presente nesses meios que merece ser denunciado (Freund, 1989).

Os meios de comunicação - impresso, televisivo e, agora, o eletrônico - têm explorado eficientemente o fascínio que as imagens fotográficas, cinematográficas e videográficas provocam no espectador, dando-lhe a ilusão de que aquilo que ele vê é a própria realidade, sem mediações.

Se o texto escrito tem o poder convencer o leitor de que as palavras traduzem e decifram a verdade, as imagens visuais elevam em indefinida potência o poder de convencimento. Mais do que prova irrefutável do fato ocorrido, tomam lugar do próprio fato, confundindo o receptor mais desatento.

A tecnologia presente nessas imagens produzidas pelo registro da luz (Dubois, 1994) tornou possível captar recortes do real com impressionante exatidão e fidedignidade, proporcionando a exploração dessas imagens pelos meios jornalísticos e também pelos historiadores em virtude de seu valor documental (Kossoy, 1989,1999).

Por outro lado, possibilitou também a criação de uma realidade fictícia com o mesmo grau de convencimento. Um aspecto interessante é como o feitiço se virou contra o feiticeiro, como pudemos ver no atentado contra 0 World Trade Center. 0 domínio da técnica possibilitou a criação da ficção com tamanha veracidade que se tornou difícil distingui-la da realidade. Assim, ao assistirem pela televisão as imagens da explosão dos prédios, muitos expectadores inicialmente custaram para acreditar que no que viam, pensando tratar-se de um filme de cinema, e não uma matéria jornalística.

Este é o aspecto que gostaria de destacar sobre essas imagens. Fotos, vídeos ou filmes, mesmo que documentários, nunca são neutros e nem totalmente objetivos. Mais especificamente sobre a fotografia, Kossoy apresenta um ponto de vista muito interessante sobre esse assunto. Para ele sempre existe uma intencionalidade que antecede toda criação fotográfica, 
seja ela jornalística ou artística. Assim, toda foto carrega consigo sempre um aspecto da realidade que a gerou e sempre uma parcela de criação, decorrente da intencionalidade do fotógrafo. Desse modo, mesmo a fotografia sendo o resultado de processos ópticos e químicos - e por isso sua natureza indiciária, segundo Dubois (1994) - existiu anteriormente uma intencionalidade humana que definiu o que iria ser registrado e como seria registrado.

0 ponto de vista de Kossoy sobre a fotografia como criação intencional é compartilhado por outros autores como Leite (1989, p.40):

(...) entre a imagem e a realidade que representa, existe uma série de mediações que fazem com que, ao contrário do se pensa habitualmente, a imagem não seja restituição, mas reconstrução - sempre uma alteração voluntária ou involuntária da realidade.

Mais adiante ela escreve:

Longe de ser um objeto neutro, a fotografia acolhe significados muito diferentes, que interferem na codificação e nas possíveis decodificações da mensagem transmitida (1989, p.40).

Se, do ponto de vista da criação, pudemos ver que as imagens não são neutras, mas, pelo contrário, produto da intencionalidade que as produziram, o mesmo se pode afirmar quanto à recepção delas.

Isto me faz pensar, ou melhor, retornar, a um ponto anteriormente discutido sobre a questão metodológica no que diz respeito à neutralidade, objetividade e subjetividade na pesquisa.

Ainda que se privilegie a produção do olhar na perspectiva de quem olha por dentro da cultura, a recepção e a interpretação serão sempre atravessadas pelo olhar daquele que olha de fora, ou seja, o pesquisador. Além disso, há que se considerar que o produtor das imagens, mesmo sendo membro do próprio do grupo estudado, deve minimamente imaginar quem 
serão os receptores virtuais de suas imagens, supondo ainda que estes não sejam necessariamente apenas aqueles de dentro de seu grupo. Assim sendo, penso que dificilmente a presença do estranho, do intruso, possa ser totalmente suprimida durante a produção das imagens e do contexto pesquisado. E ainda, mesmo que eu não seja tomado como intruso, a câmera certamente será, pois sua presença jamais será totalmente ignorada, retirando, desse modo, a naturalidade do ambiente.

Como já foi dito anteriormente, mas penso ser importante retomar, nas pesquisas em ciências humanas e sociais o pesquisador é o principal instrumento da pesquisa e nada poderá substituir sua capacidade de reflexão: o uso de palavras ou imagens são escolhas que não garantem, por si só, a aproximação em relação ao seu objeto. Desse modo, penso que 0 pesquisador não deve tentar "desaparecer" do contexto da pesquisa para que possa emergir o fenômeno. Pelo contrário, ele deve explicitar o lugar que ocupa, assim como ter clara a sua intencionalidade. A intencionalidade do pesquisador pode ser comparada à sua lente. Quanto mais precisa, melhor será o seu foco sobre o objeto.

Nesse sentido, devo esclarecer que não pretendo suprimir a minha presença como pesquisador, mas apenas buscar a possibilidade de compreensão e interpretação da realidade vivida pelos participantes da pesquisa. Assim, o lugar que os participantes ocupam na pesquisa não é daquele de mero espectador passivo, tampouco o lugar dos protagonistas exclusivos, mas o lugar de parceiros, como aqueles que apontam ao pesquisador para o que é mais significativo na realidade vivida por eles.

Gostaria ainda de esclarecer que a opção pelo uso da imagem nesta pesquisa não se deve à sua aparente objetividade e nem como meio de substituir as palavras. Em concordância com Leite (1998, p.43), entendo que palavra e imagem, o "texto verbal e 0 visual são polissêmicos e complementares (...)". Ou como disse Godard (apud Joly, 1996, p.115), "Palavra e imagem são como cadeira e mesa: se você quiser se sentar à mesa, precisa de ambas". 
Assim, a utilização do vídeo é entendida por mim como um recurso complementar, como mais uma possibilidade de captura, estreitando ainda mais a teia de aranha que venho tecendo. A imagem, segundo Bittencourt (1998, p.198), pode contribuir para a captura de aspectos visuais que transcendem a capacidade de representação da escrita. E ainda:

Na realidade, a imagem e os meios visuais, quando utilizados como instrumentos etnográficos, ampliam as condições para o estabelecimento de um diálogo fecundo com outros universos culturais". (Bittencourt, 1998, p.200)

\section{Considerações sobre o vídeo}

O vídeo apresenta algumas semelhanças em relação as outras formas de representação, porém carrega também especificidades.

Diferentemente da fotografia que é uma imagem estática, o vídeo, assim como o filme de cinema, é essencialmente imagem em movimento.

Em sua tese de Livre Docência intitulada "De Altamira A Palo Alto: a Busca do Movimento, Mario Guidi (1991) reconstrói os passos que levaram ao surgimento do cinema. Ele parte dos primeiros estudos ópticos realizados no período do Renascimento até a descoberta da fixação da imagem que deu origem à fotografia, passando em seguida para as experiências de Marey e Muybridge que, paralelamente, investiram na captura da imagem em movimento.

Samain (1998) discute a singularidade das imagens a partir de seus respectivos suportes técnicos. Partindo das considerações feitas por Dubois, Samain analisa a natureza objetal das imagens. A fotografia é uma inscrição, uma queimadura produzida pela luz em uma superfície foto sensível. Ela é simultaneamente imagem e artefato, um objeto que pode ser tocado, tem uma textura, peso, enfim, uma materialidade que não se encontra nem na imagem fílmica e nem na imagem televisiva e eletrônica. Mesmo originada da película, a imagem fílmica é apenas uma projeção e seu reflexo, abstrata, 
intocável e inatingível. A imagem televisiva, por sua vez, é uma imagem fantasma originada por feixes de elétrons projetados em uma tela fosforescente, desprovida de toda realidade concreta. Mas este não é um aspecto que pretendo aprofundar. Gostaria, neste momento, trazer outros elementos a respeito do vídeo.

Tanto a imagem fílmica quanto o vídeo são imagens em movimento, como foi dito anteriormente, distinguindo-os da fotografia. Há ainda mais uma diferença significativa: permitem o registro simultâneo da imagem e do som, ou melhor, das palavras. Enquanto a fotografia é uma imagem silenciosa, o vídeo e o filme são imagens falantes. Em relação à pesquisa, esse é um detalhe importante por duas razões: para o videomaker, essa fusão entre som (narração) e a imagem, possibilita uma significação (pela narração) simultânea ao processo captação das imagens; para o receptor, possibilita a contextualização das imagens pela narrativa presente e a melhor compreensão sobre o que foi gravado no exato momento em que ele assiste a fita ou o filme. Por exemplo: o que está sendo considerado o tema principal, o nome do local, quem são as pessoas que aparecem etc ${ }^{4}$.

O vídeo, diferentemente, do filme, possibilita ainda a apreciação imediata do produto gravado, tal como uma Polaroid em termos fotográficos. Para a pesquisa esta praticidade é um aspecto bastante relevante, sem contar no baixo custo em relação ao filme.

Na pesquisa, a observação da fita pelo videomaker é um momento muito importante, pois possibilita a ele rever e comparar o que estava sendo visto pelo visor da câmera, no momento da gravação, com as imagens obtidas e projetadas na TV. Durante a observação da gravação, ele pode também fazer comentários adicionais ou até re-significar o que foi produzido. Através da observação da fita é possível ver que, aquilo que foi visto durante a gravação, não é necessariamente aquilo que se vê pela televisão. Apenas

\footnotetext{
${ }^{4}$ Comento isso porque na pesquisa de mestrado (Kohatsu, 1999a), ao trabalhar com fotografias, tive algumas dificuldades até para localizar o tema principal, pois este nem sempre estava evidente em virtude do pouco domínio da técnica pelos participantes. Desse modo, deveria solicitar o esclarecimento do autor da foto ou partir para a interpretação de seu significado a partir dos dados disponíveis, muitas vezes recorrendo às minhas inferências.
} 
como exemplo, tremores, balanceios da câmera nem sempre são notados durante a gravação, mas ficam evidentes quando mostrados na tela do televisor.

Um outro aspecto (técnico e metodológico) importante proporcionado pelo vídeo é o processo de edição. Para realizar a montagem é necessário que se realize antes a decupagem, ou seja, a seleção das partes que deverá compor o trabalho final. Ao realizá-la puder notar que estava, de certa forma, tematizando o que havia sido gravado.

A decupagem, desse modo, permitiu uma melhor compreensão do vídeo realizado pelos participantes e, mesmo na ausência de um roteiro prévio e da falta de domínio técnico do equipamento de vídeo, possibilitou, pelo levantamento dos temas gravados, observar a presença de uma lógica no trabalho realizado. 
Contraditoriamente, convivendo ao lado dessa grandiosidade imposta pela cidade, percebia que nela ainda se preservava algo do espírito provinciano, do familiar, do privado, inclusive na esfera pública e no âmbito da política.

A presença dessa atmosfera de "familiaridade" não significava, todavia, a possibilidade de uma coesão social numa escala maior, pois, a meu ver, ela se limitava a alguns círculos sociais restritos.

Esse modo de organização social indicava, em minha opinião, o seu contrário, isto é, a presença de uma cisão no tecido social. o que quero dizer com isso é que vejo em São Bernardo a presença de pelo menos dois grandes grupos sociais distintos e impermeáveis. Um grupo formado pelos descendentes da colônia italiana e outros grupos menores de imigrantes; um outro, talvez mais heterogêneo, em certos aspectos, formado pela corrente migratória ocorrida a partir da década de 50 provocada pela oferta de trabalho pela instalação das grandes indústrias na região como a Volkswagen, Villares, Mangels, Ford, Mercedes, Chrysler entre tantos outros (Cardoso \& Lima, 1981)

Esses migrantes, muitos deles vindos de outras regiões do país como o nordeste e impossibilitados financeiramente, é que vão ocupar as periferias e os bairros mais distantes da cidade como a região da represa que não apresentava, na época, restrições quanto ao uso e ocupação do solo (Castilho, 1998)

Já as famílias dos imigrantes, instaladas desde o começo do século passado, se estabeleceram nos bairros que hoje podem ser considerados como centrais, em virtude da expansão da periferia. Muitos desses bairros ocupados pelos imigrantes italianos acabaram levando inclusive o nome de algumas famílias como Batistini, Demarchi, Farina, Marchi e até do ditador Mussoline. Existem também muitas vias que levam o nome de pessoas da colônia italiana como as ruas Ítalo Setti, Peri Ronchetti a até nome de escola, como a Escola Aldino Pinotti. Como se pode ver, é marcante a presença da colônia italiana na cidade. 
Muitas dessas famílias de imigrantes de italianos que atualmente se situam nas classes média e alta, no passado desempenharam atividades na agricultura, na indústria carvoeira e, posteriormente, na indústria de móveis, que é uma das marcas fortes de São Bernardo. Na agricultura, os imigrantes italianos, juntamente com os imigrantes japoneses, cultivavam batatas e, por esse motivo, eram chamados de batateiros pelos habitantes de outras cidades $^{8}$. Um outro setor comercial em que predomina a colônia italiana é 0 de restaurantes, existindo inclusive um bairro (Demarchi) que é conhecido como a rota dos restaurantes ou a rota do frango com polenta. A propósito, um dos membros dessa família foi prefeito da cidade no início da década de 90, mostrando, desse modo, o poder político da colônia no município.

Das cidades da região do $\mathrm{ABC}$, São Bernardo tem algumas características muito peculiares. Embora tenha sido o berço do movimento sindical dos metalúrgicos e do Partido dos Trabalhadores, politicamente tem ocorrido o predomínio das correntes partidárias mais conservadoras no município ao contrário do que se observa nas cidades vizinhas como Diadema, Santo André, Mauá e outras em que os partidos de esquerda têm predominado. Este é um aspecto que mereceria ser investigado com mais profundidade, porém entendo que não posso me propor a realizar essa tarefa no contexto desta pesquisa, por desviar-me de meu objetivo principal.

Do ponto de vista social e cultural, São Bernardo foi também o cenário em que surgiu o movimento dos "skinheads" ou "carecas do ABC", conhecidos pela violência exercida contra negros e nordestinos e outras minorias.

Como se pode observar, em São Bernardo confluem tendências muito diversas, tanto do ponto de vista político como também social e cultural. Ao mesmo tempo em que possui as características de outros municípios industriais da região, São Bernardo possui também particularidades muito interessantes decorrentes de sua formação histórica e cultural que merecem ser mais conhecidas.

\footnotetext{
${ }^{8}$ Muitas das histórias dos imigrantes italianos podem ser vistas no vídeo documentário "Bernô, a terra dos ilustres batateiros” (2002)
} 


\section{Parte - II - Sobre a pesquisa}

\section{Objetivos da pesquisa}

A presente pesquisa tem como objetivos:

1. Proporcionar o conhecimento e a compreensão da relação que ex-alunos de escolas especiais mantêm com o bairro onde moram a partir da produção de um vídeo realizado pelos próprios participantes;

2. Analisar o processo de produção do vídeo em todas as suas etapas (que serão logo apresentadas) ${ }^{1}$.

A investigação parte, inicialmente, de quatro perguntas básicas, formuladas no momento da problematização:

- Como se constituiu o universo social dessas pessoas (ex-alunos de uma escola especial) para além dos muros institucionais da escola?

- Será que a permanência na escola especial dificultou ao aluno o conhecimento de seu bairro e será que a saída da escola proporcionou essa aproximação?

- Como vivenciaram e ocuparam o espaço do bairro? Quais foram as experiências mais significativas? Em que período ocorreram (infância, adolescência, fase adulta)?

- Como é para essas pessoas (ex-alunos da escola especial) morar na periferia? Será que o contexto comunitário (se existente) favoreceu de algum modo a sua socialização?

\footnotetext{
${ }^{1}$ Este segundo objetivo foi posteriormente inserido após eu ter refletido que o processo de produção do vídeo (que implica na relação entre pesquisador e participante) é tão importante como material de estudo como o próprio produto em si, no caso o vídeo. Isto marca e caracteriza inclusive a metodologia empregada, em que o pesquisador não é um mero observador, mas interage ativamente com os sujeitos. E é por isso que digo que a pesquisa tem sido uma permanente elaboração, com mudanças, descobertas e re-significações a cada passo dado.
} 
Há uma quinta pergunta que não se relaciona diretamente com o objetivo da pesquisa, mas se refere ao recurso escolhido, no caso o vídeo, e que penso ser importante registrar - afinal é uma dúvida que me inquieta. A questão, portanto, é:

- Em que medida o vídeo auxilia no conhecimento da realidade vivida pelo participante da pesquisa?

\section{Participantes:}

São três ex-alunos de escolas especiais para alunos com deficiência mental:

- Luzia, 23 anos, sexo feminino, funcionária de uma empresa de limpeza.

- Mário, 41 anos, sexo masculino, trabalhador de uma oficina abrigada.

- Márcio, 24 anos, sexo masculino, trabalhador de uma oficina abrigada.

Foram utilizados basicamente critérios para escolha dos participantes:

- Independência na locomoção;

- que morassem desde criança no bairro;

- que demonstrassem interesse na participação da pesquisa.

\section{Local da pesquisa}

A pesquisa ocorreu em três bairros do Município de São Bernardo do Campo:

- Boa Vista (favela)

- Vila Rosa (bairro residencial, comercial e industrial)

- Jardim das Orquídeas (bairro situado em zona de manancial)

\section{A proposta:}

Cada participante da pesquisa, em posse de uma câmera de vídeo, realizou vários registros do bairro em que mora. Foi solicitado a eles que 
mostrassem o bairro, os lugares que eles conheciam, que mais gostavam etc. As gravações não seguiram um roteiro pré-estabelecido, sendo realizadas de modo espontâneo pelos participantes.

As gravações dos bairros foram realizadas individualmente. A primeira experiência (Luzia) foi considerada como piloto, sendo a gravação realizada em um único encontro, com cerca de quinze minutos de duração. A segunda (Mário) ocorreu em cinco encontros e aproximadamente 60 minutos de gravação. A terceira e última (Márcio) foi realizada em seis encontros e aproximadamente 90 minutos de gravação.

Todas as gravações foram realizadas em minha companhia. Algumas instruções básicas sobre o funcionamento, recursos e manejo do equipamento foram dadas inicialmente e durante o processo, quando era necessário.

\section{Procedimentos / Etapas:}

5.1 Contato com o participante, esclarecimento da proposta da pesquisa e agendamento para a data da gravação do vídeo;

5.1 Encontros para realizar as gravações;

5.1 Observação das cenas gravadas, comentários do participante sobre o resultado obtido, escolha das cenas que se pretende manter e outras que se deseja cortar, escolha do fundo musical (se desejado) e esclarecimentos que forem necessários;

\subsection{Edição.}

A edição foi realizada em dois estúdios diferentes e somente Luzia e Márcio puderam participar de parte do processo pela dificuldade em conciliar a agenda dos locais com a dos participantes.

\section{Organização e reflexão sobre o material coletado}

0 material consiste basicamente em:

- Registro em vídeo realizado pelos participantes; 
- Registro em áudio das conversas realizadas com os participantes

- Anotações de campo realizadas pelo pesquisador sobre todo processo de produção.

As gravações foram realizadas na experiência piloto com uma câmera de vídeo no formato VHS e as duas posteriores em câmera digital em função da qualidade de som e imagem obtidas na primeira experiência.

\subsection{Organização dos materiais}

A organização dos materiais seguiu os passos seguintes:

\subsubsection{Transcrição das falas contidas no vídeo e no áudio.}

\subsubsection{Separação do material de vídeo em pequenas} cenas/ assuntos.

Esta terceira etapa foi realizada após várias observações do material gravado e, a partir da identificação do assunto, a ele será dado um título. Exemplo: A casa de Luzia. Junto ao assunto gravado será registrado o momento em que a cena aparece no filme, ou seja, a minutagem. Ex: 01:58 - Panorâmica da favela. Este processo prepara o material para o trabalho de edição e serve também como facilitador do trabalho de análise.

\subsubsection{Discussão sobre os assuntos gravados.}

\subsubsection{Discussão sobre 0 conjunto produzido pelos participantes}

Nesta última etapa realizo uma discussão sobre o material produzido no sentido de estabelecer algumas relações e destacar aspectos comuns interessantes. 


\section{CAPÍTULO IV}

\section{APRESENTAÇÃO DAS EXPERIÊNCIAS}

Neste capítulo apresento as experiências realizadas juntamente com Luzia, Mário Márcio.

A experiência de Luzia foi a primeira a ser realizada e, por esse motivo, foi considerada como uma experiência piloto.

A organização e a apresentação dos trabalhos segue basicamente a mesma estrutura, dividida em duas partes.

$\mathrm{Na}$ primeira parte faço a apresentação dos trabalhos e dos participantes e, em seguida, apresento o relato das primeiras conversas e um resumo dos encontros em que foram realizadas as gravações de vídeo e áudio. Já procuro apontar nesta parte os caminhos que pretendo seguir em minhas reflexões posteriores nos breves comentários que inseri no texto ou nas notas de rodapé, quando entendi serem mais adequadas.

A segunda parte é o exercício de compreensão e reflexão acerca das experiências. A intenção foi orientar a discussão a partir de dois eixos que foram sendo identificados ao longo do percurso: a) o bairro como espaço vivido e b) sobre o tempo vivido no bairro. 0 primeiro discute os locais gravados e as relações sociais mantidas no bairro; o segundo retoma aspectos relativos às memórias do bairro e também sobre as memórias do narrador sobre a sua própria história. Apesar da estrutura comum, procurei respeitar a especificidade de cada experiência e, por esse motivo, cada trabalho se apresenta de modo bastante particular.

Há ainda neste capítulo o que denomino como Terceira Parte, em que realizo uma discussão conjunta dos três trabalhos, buscando estabelecer relações entre as experiências tão distintas e particulares. 


\section{LUZI A}

\section{Primeira Parte}

\section{Conhecendo o Boa Vista em companhia de Luzia}

Apresento ao leitor a experiência de Luzia em sua favela conhecida como Boa Vista. Nesta primeira parte, apresento os relatos dos encontros. Como poderá ser observado, tivemos a companhia de Alfredo que, infelizmente, não pode prosseguir na pesquisa por razões pessoais.

Os textos a seguir seguirão na forma de diário de campo, tal como foram realizados.

\section{6 de maio de 2003 - O reencontro com Luzia e Alfredo ${ }^{1}$}

Foi numa tarde quente e ensolarada de outono, mais precisamente no dia 16 de maio de 2003. Faltavam poucos minutos para as 15:00 horas, conforme havíamos combinado por telefone. Marcamos de nos encontrar na repartição pública em que Luzia trabalhava. Ela havia sido contratada por uma empresa terceirizada de limpeza.

Quando o relógio marcou três horas liguei para o celular de Luzia. Ela me disse que já estava de saída. Instantes depois, subi até a outra portaria e lá estava ela com uma outra moça. Apresentou-me como o "professor". Disse que Alfredo já se encontrava ali e que logo viria. Enquanto esperávamos, sua colega foi embora e Luzia ficou conversando com o guarda da portaria. Pouco depois, vi Alfredo vindo do estacionamento. Acho que quando ele me viu esboçou um sorriso discreto.

\footnotetext{
${ }^{1} \mathrm{O}$ nome do rapaz não foi mantido porque ele não participou da pesquisa.
} 
Conheço Alfredo e Luzia desde a época da Oficina de Fotografia, quando eles eram participantes. Alfredo participou desde a primeira etapa, em 1998, quando a Oficina estava vinculada a minha pesquisa de mestrado. Luzia começou a participar na segunda etapa, no mesmo ano, no momento em que ingressaram outros participantes e outros coordenadores.

Convidei-os para irmos à padaria. Fomos conversando no caminho, ou melhor, fiquei ouvindo a conversa deles a respeito da repartição pública. Chegando à padaria, comecei a perguntar coisas sobre eles, pois fazia tempo que não os via.

Alfredo estava com 20 anos disse que estava trabalhando como estagiário numa empresa, montando caixinhas para massinhas. Disse que depois que seu contrato terminar, por volta de julho, não voltaria mais para a oficina abrigada. Disse que lá os tratavam como crianças. Isso me chamou a atenção. Ele parecia confiante e acreditava que poderia ser efetivado, embora soubesse que a firma estava demitindo muitos funcionários. Fez comentários sobre um colega, ex-aluno de uma das escolas especiais, que brigou e foi mandado embora. Contou também que havia terminado o supletivo do colegial. Perguntei se havia sido difícil, e ele disse que não.

Luzia estava com 23 anos e contou que parou de estudar. Estava no supletivo, fazendo a sexta-série. Parou por causa do serviço. Disse que por causa das inaugurações das novas escolas teve que trabalhar mais. Atualmente, trabalha trabalha na repartição pública, mas disse que gostaria de ser transferida para a escola especial onde estudou.

Eles começaram a falar dos colegas e em certo momento Alfredo disse que eles haviam se desviado do assunto.

Alfredo estava com um álbum de fotos que havia tirado quando foi com alguns colegas em uma excursão para Aparecida do Norte. Nas fotos ele aparecia junto a diferentes garotas, mas disse que não estava namorando mais. 
Após a conversa inicial e alguns goles de refrigerante, falei sobre a proposta. Disse-Ihes que desta vez a idéia era trabalhar com vídeo, filmando os lugares onde moravam. Alfredo disse que onde morava não tinha muitos lugares interessantes. Eu já tinha escutado essa conversa antes durante a Oficina de Fotografia. Referiu-se a uma quadra em sua vila. Disse que depois de certo trecho ficava perigoso. Já Luzia disse que seu bairro não tinha problemas.

Alfredo disse que no final de maio, no dia 31, Luzia faria uma festa de aniversário e que esta poderia ser uma ocasião para filmar. Disse que era uma boa idéia, mas esclareci que a proposta era filmar o bairro. Acho que aqui pude perceber uma certa diferença de interesses. Pensei que aqui já começava a direcionar o trabalho. E por que não definir?

Procurei explicar melhor a idéia. Luzia falou, "é como uma reportagem". Disse que era isso mesmo, como uma reportagem sobre o local onde moravam. Acho que ela captou a idéia. Alfredo é sempre reservado. Achei que ele poderia até desistir. $E$ isso também me chamou a atenção - o interesse deles.

Perguntei quanto tempo eles moravam no bairro. Luzia disse que morou desde que nasceu. Alfredo disse que há uns dez anos. Disse que poderíamos filmar os lugares onde eles tinham recordações. Luzia começou a entrar na idéia.

Falei também da possibilidade de usarmos o laboratório da faculdade onde eu lecionava. Contei que poderíamos fazer a edição lá. Expliquei o que era uma edição: separar os melhores trechos, colocar música etc. Disse que para fazer um filme deveríamos partir de um roteiro.

Alfredo disse que mudaria de turno e passaria a sair da empresa às 17 horas. Disse que poderíamos marcar para sábado. Ele me esperaria na Chácara Silvestre para irmos juntos à casa de Luzia.

Depois de mais de uma hora de conversa fomos embora. Foi uma boa conversa e fiquei muito contente de tê-los reencontrado e por saber que faríamos um trabalho juntos novamente. 


\section{Sábado, 24 de maio de 2003 - A primeira gravação}

Após nosso primeiro reencontro havia combinado com Luzia e Alfredo que nos encontraríamos no sábado para fazer a primeira gravação no bairro de Luzia. Eu havia ido até sua casa há alguns anos, quando fazíamos a Oficina de Fotografia, mas não me recordava mais de como se chegava até lá. Além disso, não sabia se seria muito seguro entrar sozinho em sua favela. Preconceito? Talvez. Por via das dúvidas combinei com Alfredo de nos encontrarmos na Chácara Silvestre, local em que fica o Museu do Folclore, onde realizávamos nossos encontros da Oficina de Fotografia.

Marcamos às duas horas. Era um sábado ensolarado de outono, quente sob o sol e frio na sombra. Soprava um vento lancinante e frio, mas era um dia bonito, perfeito para gravação.

Antes de sair de casa liguei para Luzia para confirmar. O telefone tocava, mas ninguém atendia e caía na caixa postal. Comecei a desconfiar que nosso encontro não iria acontecer - achei que ela poderia ter se esquecido. Algum tempo depois voltei a ligar e a irmã de Luzia atendeu dizendo que ela não estava, mas que deveria retornar logo. Minha certeza sobre o esquecimento deles aumentava; estava quase convicto de que ela havia se esquecido. Insisti e, finalmente, pouco antes do horário de sair de minha casa, consegui falar com Luzia que me confirmou, dizendo que estava tudo conforme havíamos combinado. Fiquei surpreso, aliviado e contente, mas não menos ansioso. Surpreso porque já estava convicto de que ela havia se esquecido e contente pelo fato dela ter se lembrado. Por que aliviado? Não sei responder precisamente. Acho que é um aspecto para se pensar.

Mesmo que eu não tivesse conseguido falar com Luzia eu pensei que deveria ir ao encontro de Alfredo. Achei menos provável ele se esquecer e, afinal, era meu compromisso. 
Quando fui chegando no local combinada, não vi ninguém perto do portão, mas ele estava sentado do outro lado da rua.

No caminho, Alfredo foi contando que não havia dormido direito naquela noite, pois havia passado a noite na delegacia. Faz uma pausa como se esperasse a minha pergunta: - Por que, o que você fez? Contou que estava andando com seus colegas e alguns deles estavam "zuando". Pelo que eu me lembro de seu relato, um deles pegou uma garrafa, atirou para o alto e se espatifou quando veio ao chão. Alfredo contou que chamava a atenção dos colegas, mas eles não paravam. Foram então abordados por policiais que vieram em uma viatura e levaram todos para o distrito policial, onde passaram a noite no "xadrez".

Entramos na favela. Fomos conversando até chegar à casa de Luzia, que fica em um dos pontos mais altos da favela. Durante o caminho, perguntei a Alfredo se era tranqüilo uma pessoa estranha como eu transitar naquela favela e ele respondeu que sim. Fizemos uma pequena parada quando ele encontrou alguns conhecidos. A conversa foi breve. Eu estava me sentindo como um estranho por razões étnicas, sociais, pelas minhas roupas, pela minha idade, enfim, tudo parecia me diferenciar.

\section{Na casa de Luzia}

Ao chegar à casa de Luzia, me senti um pouco mais seguro. Alfredo mostrou-se bastante familiarizado e à vontade. Conhecia as pessoas da casa que também o conheciam. Quando chegamos, fomos recebidos pela irmã de Luzia que pediu para que nos sentássemos e esperássemos, pois ela estava no banho. A televisão estava ligada e o aparelho de som também, um concorrendo com o outro pela nossa audiência.

Após sair do banho Luzia mostrou-nos um álbum com fotos tiradas no dia de visita do presídio onde seu irmão se encontrava. Foi somente ao ver as fotos 
do álbum que entendi que uma das pessoas que se encontrava na casa era sua cunhada e o pequeno garoto era seu sobrinho. Luzia me mostrou as fotos com muita naturalidade, sem aparentar constrangimento pelo fato de seu irmão se encontrar preso. Não parecia esperar um espanto de minha parte, nem se preocupar com o que eu poderia pensar; talvez não tenha the ocorrido que eu poderia fazer algum julgamento moral ou, ainda, que meu julgamento em nada poderia mudar um fato do qual eles já se encontravam resignados.

Alfredo foi quem tomou a iniciativa para que começássemos a gravar. Antes de sairmos, peguei meu pequeno bloco de notas e tentei propor um breve roteiro para sabermos ao menos por onde começar. Acho que não deu muito certo, talvez por eu não ter sido claro ou convincente o suficiente sobre a importância de um roteiro. Assim mesmo saímos.

\section{A gravação}

Luzia e Alfredo já conheciam a minha velha câmera de vídeo que eu já havia apresentado durante a Oficina de Fotografia e que havia Ihes mostrado em nosso reencontro. De toda forma, retomei algumas instruções básicas como o modo de colocar a fita de vídeo, o botão de gravação, os botões do "zoom". Por se tratar de uma câmera de uso doméstico ela é de uso bastante simples sem necessitar, inclusive, de ajuste de foco. Não me recordo se a preveni sobre a movimentação brusca da câmera, mas ela parecia tomar certo cuidado.

Minha consigna foi gravar locais do bairro que ela gostava. Não fui muito preciso, eu reconheço. Contudo, eu não me preocupei muito com isso e, assim, talvez não tenha insistido muito porque o que eu queria também era "deixar rolar", "ver no que ia dar". 


\section{O local}

Como relatei anteriormente, mas agora retomo mais explicitamente, Luzia mora em uma favela situada em um morro que é conhecido como Boa Vista. 0 nome é explicado pelo fato do lugar ser privilegiado no que se refere a visão que oferece da cidade. Do alto se tem uma visão panorâmica da cidade em várias direções, tal como foi mostrado por Luzia.

As casas são construídas em alvenaria, mas muitas se encontram em processo de acabamento. Desse modo, muitas construções mostram ainda os tijolos das paredes que não foram rebocadas.

As principais ruas de acesso foram asfaltadas, mas existem ainda muitas ruas de terra.

Segundo relato de Luzia, o local foi sendo transformado devido a urbanização ocorrida anos atrás.

\section{O “roteiro" improvisado}

Luzia começou mostrando a frente de sua casa, depois a Igreja na rua mais abaixo, onde ficava a casa onde moravam.

Fomos caminhando pelo bairro e logo encontramos uma quadra de futebol. Na medida em que caminhávamos fomos encontrando também algumas pessoas conhecidas por Luzia. Ela foi também mostrando a casa onde algumas pessoas conhecidas moravam. Fomos caminhando até chegarmos a uma rua com uma descida muito íngreme. A partir daquele ponto começamos a retornar. Na volta encontramos uma amiga, irmãs, cunhada e seus sobrinhos. Pouco depois sua mãe veio descendo a rua. Encerramos a gravação em frente à sua casa. Gravamos um total de 15 minutos, bem menos do que eu esperava. 


\section{Sexta-feira, 07 de novembro de 2003 - 0 reencontro para observação da gravação}

Após longo tempo conseguimos marcar uma data para assistirmos juntos a gravação. 0 reencontro aconteceu somente no dia 07 de novembro de 2003, no laboratório de TV e vídeo da universidade onde eu lecionava. A demora ocorreu em função da procura de um local mais apropriado, não somente para assistir a gravação, mas também para a edição da fita.

Durante a observação procurei gravar os comentários de Luzia, assim como as explicações que the solicitei. Todavia, a gravação em áudio não apresentou uma boa qualidade em virtude do ruído causado pelo som do vídeo. Por esse motivo não realizei a transcrição dessa fita de áudio.

Assistimos a fita duas vezes. Luzia sinalizou para a parte que gostaria de ver suprimida, ou seja, a parte em que Alfredo a gravou.

Pudemos perceber alguns trechos em que as imagens ficaram tremidas. Perguntei se havia interesse de Luzia em realizar novas gravações, mas ela se mostrou satisfeita com o que viu.

Combinamos, então, para realizar a edição da fita. Na primeira vez Alfredo não compareceu e Luzia disse que não poderia ir naquele momento porque estava esperando o namorado, pois haviam marcado de se encontrarem após o serviço. Sugeri marcarmos uma outra data e comunicarmos o laboratório de TV pois, assim, quem sabe, Alfredo, que participou da gravação, também poderia assistir. Marcamos uma nova data. Alfredo compareceu, mas desta vez Luzia não pode ir, pois disse que recebeu a notícia que teria que trabalhar algumas horas a mais. Perguntei a Alfredo se poderíamos marcar uma outra data, mas ele respondeu negativamente, pois a partir da próxima semana mudaria de turno no serviço. Perguntei a ele o que pensava sobre fazer a edição da fita sem a presença de Luzia, mas ele discordou, dizendo que era ela quem 
havia feito a gravação e seria ela quem deveria fazer a edição. Concordei com sua argumentação e cancelamos a edição.

Entrei em contato com Luzia dias depois e ela disse que seria difícil marcar uma nova data, pois estaria se mudando em virtude de seu casamento; eu disse-Ihe, então, que faria a edição e lhe mostraria posteriormente e ela concordou. 


\section{Segunda Parte}

Trabalho de compreensão, discussão e reflexão acerca do material produzido.

Nesta segunda parte do trabalho apresento uma reflexão sobre a experiência de Luzia. Proponho para realização da tarefa uma subdivisão em duas partes:

a) O bairro como espaço vivido: uma retomada dos lugares gravados e uma discussão sobre as relações estabelecidas.

b) O tempo vivido no bairro: um mergulho no tempo, nas histórias e lembranças narradas.

\section{a. $O$ bairro como espaço vivido:}

Ao assistir o vídeo gravado por Luzia posso observar a presença dos seguintes assuntos:

- A casa de Luzia

- A rua

- A casa onde Luzia morava

- A rua da casa onde Luzia morava

- A vista panorâmica de sua favela e dos bairros vizinhos

- A quadra

- As casas das pessoas conhecidas

- A igreja

- As pessoas da família na rua

Como foi explicitado anteriormente, a gravação não seguiu um roteiro pré-estabelecido. Luzia começou a gravar em frente a sua casa, fomos seguindo rua abaixo, passamos pela casa onde ela morava anteriormente e 
depois pela rua que Ihe trouxe recordações da infância. Conforme íamos caminhando Luzia ia identificando a casa de alguma conhecida, comentando algum aspecto de sua história ou alguma característica do bairro. Ao recordar agora seu percurso, tenho a impressão que o bairro era para ela algo como um texto pronto para ser lido. O roteiro estava ali, era só caminhar pelas ruas.

\section{Sobre os assuntos gravados}

\section{A casa de Luzia}

Luzia fez dois registros de sua casa. A primeira foi no início das gravações. 0 único comentário que fez foi dizer que é sua casa. Explicou que a menina que aparece no andar de cima é cuidada por sua mãe. Pergunto quem mora com ela e então me responde: "eu, minha mãe, meu pai, meus sobrinhos R., o A., minha cunhada que está grávida de gêmeas, meu irmão que está preso... Dorme bastante gente aí".

\section{A rua}

Luzia fez vários registros de sua rua, em diferentes momentos. Como foi descrito anteriormente, é uma rua asfaltada que vai do começo ao fim da favela. A primeira tomada foi logo no início, muito breve e sem comentários. A segunda tomada foi também muito breve, no sentido ascendente, quando estávamos retornando para entrar na rua da igreja. Nesse momento também não fez comentários. Pode-se ver as crianças brincando na rua, mas ainda não comenta. Talvez ela não esteja necessariamente olhando para aquilo que me chama atenção.

O primeiro comentário ocorre quando ela está gravando as pessoas da família que se encontram na rua. É nesse momento que ela fala 
espontaneamente sobre o clima de final de ano em seu bairro: as pessoas se arrumando, fazendo comida, se preparando para a festa. Luzia faz um movimento com a câmera e mostra a rua no sentido descendente, quando capta novamente as crianças na rua. Pergunto sobre as crianças e ela confirma que elas ficam bastante na rua, inclusive seus sobrinhos. É nesse momento também que ela finalmente concorda com Alfredo, dizendo que a noite o bairro fica mais perigoso.

A última tomada ocorre no final da gravação. Ela registra dois meninos brincando de carrinho e comenta: "a molecada brincando..."

Pergunto o motivo pelo qual falam mal do bairro. Ela explica então que certa vez roubaram uma caminhonete, mas justifica: "mas nem por isso o bairro deixa de ser bom". E finaliza: "Sempre no meio do pacote de feijão, sempre tem um que vem estragado, né".

O que me chama atenção é que Luzia fez várias tomadas de sua rua, tanto no sentido ascendente, como no sentido descendente, e me pareceu que seus comentários surgiram somente com as minhas indagações. Penso que isso pode ter ocorrido porque o que estava sendo registrado the era tão natural e não lhe causava estranheza, não sendo necessário, portanto, comentários ou indagações. E penso que este seja um aspecto que caracteriza seu olhar sobre seu bairro que merece ser destacado. O olhar de Luzia não é o olhar do estrangeiro, do intruso; é o olhar de quem ali vive, é um olhar mergulhado em seu ambiente, sem o distanciamento necessário para lhe causar alguma estranheza, surpresa ou admiração. Até a violência que chama atenção de Alfredo não é vista por Luzia como algo que lhe cause estranhamento.

Todavia, seu olhar não é prisioneiro do aqui e agora, ele não se acomoda somente à superfície do visível. Ele também é capaz de mergulhar na profundeza do tempo e recordar as experiências vividas naquele local. É a rua que lhe evoca a lembrança do final de ano, quando as pessoas se preparam para a festa. 


\section{A casa onde Luzia morava}

Um pouco diferente dos registros da rua, ao fazer uma tomada de sua antiga casa, Luzia começa a contar espontaneamente que era a casa onde morava, construída por seu pai. Foi onde morou por dez anos até se mudarem para a casa atual. Embora ela e sua família não morem mais nessa casa, é lá que ainda reside um pedaço de sua história.

Luzia fez dois registros de sua antiga casa: nessa primeira vez, quando fez este relato, e uma segunda vez quando retornamos por essa rua. Ela faz novamente um comentário: "Aqui quando antes era tudo barraco, da ponta até aqui era tudo meu, tudo do meu pai. Aí passou a urbanização e mudou tudo".

\section{A rua de terra}

Passamos por esta rua duas vezes, uma na ida e outra na volta. É a rua onde fica a igreja e, em frente a ela, sua antiga casa. Nesse local ela retoma as lembranças de sua infância: "Essa rua aqui... (risos). Nós aprontamos muito aqui, professor. Cresci aqui. Nós brincamos muito aqui nessa rua, eu, minhas irmãs e minhas colegas. Hoje muitas casadas e as outras encalhadas".

Recorda também que brincava com um amigo que hoje se encontra preso. Seu olhar transcende o momento presente e viaja no tempo. Ao relatar um pouco de sua história contida naquele espaço, ela me passa a impressão de uma certa nostalgia de um tempo que se foi: seus amigos, as brincadeiras, 0 tempo da infância. Essa impressão retorna em outros momentos. 


\section{A vista panorâmica de sua favela e dos bairros vizinhos}

Luzia passeia com a câmera, captando a vista da favela, mas não faz nenhum comentário. Após passar pela quadra em seu movimento de câmera, retoma novamente à vista panorâmica. Esta vista é proporcionada pelo fato do local ser um dos pontos altos da favela. Pergunto o que ela conhece no bairro e ela responde que conhece tudo: as vizinhas, a amiga da mãe, quase todo mundo, dizendo ainda que as pessoas são legais.

Luzia faz outras tomadas panorâmicas. Em nossa caminhada paramos diante de um descida íngreme. Luzia explica que a rua que desce leva para a escola onde estudam muitas crianças do bairro, inclusive seu sobrinho. De onde estamos é possível ver boa parte da cidade. Luzia explica: "Lá no fundo é o centro de São Bernardo".

Em certo momento, ela capta novamente a vista da cidade e indica a rua do piscinão.

Quase no final da gravação, quando já havíamos retornado para perto de sua casa, Luzia faz mais uma tomada panorâmica. É um morro distante que se pode ver de onde estamos. Ela diz: "Lá é o Baeta. O bairro do Baeta Neves. É bem no final, bem no finalzão, a Anchieta". Ela explica que de dia é difícil localizar a Anchieta, mas a noite é possível ver os carros passando.

A última vista tomada por Luzia é de um outro morro, situado em outra direção. Ela explica que embaixo fica a rua dos Padres, o caminho que vai para o Sítio dos Vianas e por onde se vai para Santo André. "Esse caminho aqui sai bem em Santo André. Eu passo por ele quando vou na casa da minha avó".

$\mathrm{O}$ fato da favela ficar situada em um morro possibilita a vista da cidade em várias direções. De um lado, o centro da cidade, do outro, o bairro do Baeta Neves; na outra direção, o caminho para Santo André. É uma vista privilegiada e possivelmente foi isso que deu o nome ao local: Boa Vista. 
Luzia demonstrou um bom conhecimento da geografia da cidade a partir da visão proporcionada pelo morro. Penso que dificilmente a escola especial the ofereceria esse conhecimento ou, quem sabe, mesmo a escola comum.

\section{A quadra}

Como me referi anteriormente, em seu movimento com a câmera Luzia captou um pedaço da quadra, mas não fez nenhum comentário. Ela referiu-se à quadra somente quando retornávamos pela rua, no momento em que lhe perguntava sobre o que havia de "legal" para conhecer no bairro: "Aqui tinha bastante coisa legal, né. Hoje não tem muita coisa não. Tem a quadra de esportes". Percebo novamente como seu comentário se refere a um tempo que já se passou e se refere a quadra como algo ainda bom no presente. Embora a quadra seja lembrada como um lugar "legal" em seu bairro, Luzia não realizou tomadas privilegiadas desse local. Não perguntei se ela freqüentava a quadra, mas de toda forma, ela não a incluiu como espaço de recordações. É possível que mesmo não tendo um significado pessoal, ela entenda que a quadra é um local importante paras as pessoas da favela.

\section{As casas das pessoas conhecidas}

Luzia fez algumas tomadas de casas de pessoas conhecidas. A primeira foi a casa da N., amiga de sua mãe. Durante o percurso, ela grava uma senhora que se encontra de pé, em frente a porta de sua casa. Luzia cumprimenta a senhora, mas não para.

Certo tempo depois, Luzia encontra uma outra senhora com sua filha adolescente e as apresenta.

Quando retornávamos pela rua de terra, onde se localizava sua antiga casa e a igreja, Luzia mostra a casa de uma outra amiga. "Aqui é a casa da L., que era da mesma igreja, só que hoje ela é de outra igreja também". 
Conta que trabalharam na limpeza de um colégio durante um final de semana.

Ao lado da casa da colega, Luzia mostra a casa do pastor da igreja.

Seu último registro sobre casa de pessoas conhecidas acontece quando já estamos de volta na rua de sua casa. Ela grava e apenas comenta: " $A$ casa da $T . . . "$.

Ao falar das casas, de certa forma, ela fala também das pessoas, mesmo elas não estando presentes. 0 espaço do bairro não é meramente um contorno geográfico, mas significado e marcado pelas relações sociais. Luzia demonstra um conhecimento vivo de seu entorno, produzido pelas suas vivências ao longo de todos esses anos em que mora no bairro.

\section{A igreja}

É o único momento em que Luzia faz referência a algo antes de ser gravado. A conversa sobre a igreja surgiu quando retornávamos subindo a rua, quando the perguntei o que havia de "legal" para conhecer no bairro. Foi nesse momento que Luzia disse que atualmente não existiam mais coisas como antes. Perguntei o que havia de "legal"antes e ela responde:

Antes tinha bastante coisa, né. Ficava com o som ligado no meio da rua... Hoje não tem mais isso. A turma hoje só serviço, casa e metade dos meninos se casaram, outros foram presos... Antes tinha barraca de vender roupa, bazar da pechincha para ajudar, os irmãos da igreja fazendo culto ao ar livre, as mães mesmo ia fazer campanha pra poder ajudar nos asilos. Hoje em dia a gente não faz mais nada disso.

Luzia conta que muitas atividades eram promovidas pela igreja, mas que atualmente não conta mais com os jovens daquela época. Ela conta que ainda freqüenta a igreja, mas só de vez em quando. É nesse momento da conversa que entramos na rua da igreja, gravada por Luzia. 
Ao entrarmos na rua da igreja, Luzia conta que antes, quando dava meio dia, o pastor fazia a oração, assim como fazia pela manhã, acordando o pessoal, pois as caixas de som ficavam para fora. Conta que o pastor foi embora para a Bahia.

Observo mais uma vez um certo ar nostálgico em seu relato, sobre algo bom que acontecia no passado e que hoje não ocorre mais. Os jovens se casaram, ou trabalham ou foram presos. Até o pastor foi embora.

É possível notar que a igreja exercia um poder de agregar os jovens do local, assim como promover o espírito comunitário entre as moradores através de bazares, feiras com intuito de ajudar pessoas mais necessitadas do que eles. Com o tempo as pessoas foram se dispersando, sobrando muito pouco daquilo que um dia existiu em seu bairro. É assim que Luzia vê a história de seu bairro.

\section{As pessoas da família na rua}

As últimas tomadas são feitas na rua em frente a sua casa com a presença de pessoas da família e uma amiga. Ali se encontram suas irmãs, seus sobrinhos, sua cunhada e uma amiga.

O espaço da rua parece uma extensão da casa: as pessoas conversam, o sobrinho brinca. Em certo momento levam até um susto por causa de um carro que sobe a rua e quase atropela o menino. Certo tempo depois aparece um outro sobrinho descendo a rua, correndo descalço. Depois vem a mãe, acompanhada de outras mulheres.

\section{A favela como espaços de vivências compartilhadas: a vida comunitária, os amigos e vizinhos}

O que tentarei expor a seguir é um pouco do que pude compreender do olhar de Luzia sobre seu bairro, enfocando agora a favela como espaço vivido. 
O meu ponto de partida é novamente uma pergunta: como Luzia se relaciona com o lugar onde vive?

Partindo das primeiras impressões, pude notar a sua familiaridade com a favela onde mora. Com a intenção de verificar o sentido da palavra "familiar" fui ao dicionário Aurélio (Ferreira, 1999) e encontrei alguns significados interessantes que reforçam bem a idéia que gostaria de passar: "respeitante à, ou próprio da família; doméstico; que pertence ao cotidiano; que se conhece por haver visto, praticado, estudado muitas vezes; íntimo, cordial, afetuoso; pessoa da família entre outros".

A favela para Luzia é familiar em todos esses sentidos: uma extensão de sua família, pertencente à esfera do cotidiano, um local conhecido, habitado com o qual ela mantém uma relação de intimidade e afeto.

Luzia circula pela favela com muita tranqüilidade, demonstra conhecer a sua história que, aliás, se mistura um pouco com a sua: "Aqui quando antes era tudo barraco, da ponta até aqui era tudo meu, tudo do meu pai. Aí passou a urbanização e mudou tudo".

O espaço da favela the é familiar dando-me a certeza de que aqueles caminhos foram trilhados infinitas vezes, aquelas ladeiras percorridas acima e abaixo em dias de sol e chuva, subindo e descendo, gastando as solas dos sapatos e deixando as suas marcas e a suas pegadas. Poderia ser chamada também de Ladeira da Memória, por que não?

E seu conhecimento não se restringe aos limites internos da favela, apontando para vários pontos e indicando: "Lá no fundo é o centro de São Bernardo"; "Lá é o Baeta, o bairro do Baeta Neves. E bem no final, bem "no finalzão, a Anchieta"; "Esse caminho aqui sai bem em Santo André".

Seu conhecimento sobre o bairro e as redondezas não é como 0 conhecimento acadêmico como muitas vezes se ensina na escola, distante, frio, impessoal. Seu conhecimento de geografia é vivido, experienciado e os caminhos e as trilhas de seu mapa não foram apenas "decorados", mas 
caminhados com seus pés. Como ela mesma diz: "Eu passo por ele quando vou na casa da minha avó".

Conforme havia dito anteriormente, o bairro para Luzia não é meramente um contorno geográfico, mas, sobretudo, um espaço habitado, significado e marcado pelas relações sociais. Quando lhe pergunto o que conhece no bairro esperando obter como resposta indicações de lugares da favela - surpreendome com a sua resposta, pois o que surge não é o espaço, mas as pessoas: "Nesse pedaço tudo, professor. Minhas vizinhas, a amiga da minha mãe. (...) Conheço quase todo mundo".

É ali que moram as pessoas conhecidas, as suas amigas, as amigas de sua mãe, suas filhas e, também, o lugar onde viviam seus amigos que hoje não se encontram mais lá por motivos diversos.

\section{O espaço compartilhado: o encontro entre a casa e a rua}

O que vejo nas imagens gravadas por Luzia? O que mais me chama atenção é a quantidade de pessoas na rua. As pessoas ocupam o espaço público das ruas, se juntam para conversar, namorar, brincar, jogar bola ou dominó nas mesinhas. Dá-se a impressão que a rua é a extensão da casa, algo como um quintal coletivo.

Outras imagens captadas mostram mais crianças brincando, tanto acima quanto mais abaixo na rua e até ela comenta: "a molecada brincando..."

Em sua gravação chamou-me a atenção também uma senhora que aparece sentada em frente à sua casa, como se estivesse tomando sol. Não me pareceu ter sido gravada intencionalmente por Luzia, mas como tantas outras cenas e pessoas gravadas "acidentalmente" acabam compondo um pouco da atmosfera do local. Por falar em atmosfera do local, há dois aspectos que não foram registrados em imagem, mas comentados por Luzia.

O primeiro se refere à presença da violência no bairro. Segundo Luzia, seu bairro não é um lugar violento, opinião contestada diversas vezes por 
Alfredo. Ela não nega que a noite o bairro fica mais perigoso e que certa vez ocorreu o roubo de uma caminhonete. Mas ela diz, "nem por isso o bairro deixa de ser bom. Sempre no meio do pacote de feijão, sempre tem um que vem estragado, né".

Nessa frase Luzia resume a opinião que tem de seu bairro; é um bairro bom, as pessoas são legais e para ela é isso que importa.

De fato, em seu relato não comparecem falas sobre acontecimentos violentos. Seu olhar se dirige para outro foco, diferentemente do olhar de Alfredo.

O segundo aspecto comentado por Luzia, mas que também não pode ser registrado em imagem, é o clima de final de ano: as pessoas se arrumando, fazendo comida e se preparando para a festa. Seu relato me fez recordar do clima descrito por Clemente (1998, p.09) sobre alguns bairros da Zona Leste de São Paulo na década de 70:

Nas ruas, sentiam-se os cheiros de bolos e de comida diferente dos finais de semana, quando os pratos mais saborosos eram trocados entre os vizinhos. Havia algazarra da molecada, feijoada para comemorar a laje pronta, excursão para a Praia Grande e Aparecida do Norte. Estas atividades tornavam o sábado e domingo diferentes do restante da semana. Eram dias de prazer.

Infelizmente a pesquisadora observa que as mudanças ocorreram na periferia onde viveu a sua infância: "No lugar da solidariedade o que emerge é a violência (...) Em alguns lugares não se trocam mais pratos saborosos entre os vizinhos, mas drogas" (1998, p.10).

Por outro lado, Clemente observa também que em alguns bairros havia resistência dos moradores e uma busca de alternativas de vida frente à violência e à opressão capitalista, aspecto que ela toma como objeto de sua pesquisa, mais especificamente o Jardim São Carlos, onde a comunidade havia experienciado um outro modo de relação decorrente de sua organização política em torno da luta pela moradia. 
Em sua pesquisa sobre o Jardim São Carlos, Clemente comenta:

Por meio deste caminho fui descobrindo essa vila de periferia, repleta de paradoxos. Paradoxos porque, em um mesmo espaço nomeado de periferia, onde já se pressupõe a existência de miséria, da violência, da falta de cidadania, enfim, de uma série de exclusões, emergem solidariedades, amizades, alegrias e prazer (1989, p.20).

Em concordância com Clemente, percebo também o bairro de Luzia desta forma, um espaço repleto de paradoxos: ao lado da pobreza, da violência, a solidariedade, a amizade e a alegria.

Um outro aspecto que me faz comparar a favela de Luzia com o Jardim São Carlos pesquisado por Clemente é em relação às crianças. 0 trecho é um pouco longo, mas gostaria de reproduzi-lo na íntegra para não perder o sentido dado pela autora:

As crianças se entretêm com brinquedos improvisados, molham-se com mangueiras ou com baldes d'água. Elas são muito importantes no bairro. Observa-se que em sua volta há toda uma rede de sociabilidade, desenvolvida pelos adultos, que as protege dos perigos expressos na rua (carros, violência). Os adultos, mesmo em papos empolgados regados a cerveja, mesmo que não façam parte do núcleo familiar das crianças, estão sempre alertas em relação a elas. (1998, p.26)

Mais adiante ela continua:

O que se observa no Jardim São Carlos é que, ao mesmo tempo em que as crianças assistem à TV ou, quando se tem mais dinheiro, jogam videogame, elas são estimuladas a apropriar-se da rua com suas brincadeiras. É comum ver crianças muito pequenas, algumas aprendendo a andar, transitando pelas ruas. Um olhar distraído pode interpretar isso como desleixo da família, especialmente da mãe, mas não é o que ocorre, porque na verdade a rede de sociabilidade criada em torno da criança que permite ter segurança mesmo quando o pai ou a mãe não estão por perto (1998, p.27). 
No bairro de Luzia parece existir também o que Clemente denomina como rede de sociabilidade; as crianças não são olhadas e cuidadas somente pelas pessoa da família, mas pelas pessoas do entorno.

Esse aspecto pude presenciar, sendo inclusive registrado por Luzia, quando seu sobrinho brincava na rua com o velocípede e o carro aproximou-se em velocidade. A pessoa que acudiu o pequeno não foi sua mãe, mas aquela que prestava atenção ao menino e estava mais próxima dele. A diferença que percebo é que no Jardim São Carlos, segundo a pesquisadora, os motoristas se intimidam com a presença de crianças na rua e reduzem a velocidade, ao contrário do que pareceu ocorrer na favela de Luzia.

De certo modo, vejo que a favela de Luzia se parece um pouco com 0 Jardim São Carlos no que diz respeito ao que Clemente chama de rede de sociabilidade. Talvez o Boa Vista não seja mais o que foi um dia, com as pessoas mobilizadas em torno de objetivos comuns, organizando festas, bazares, brincadeiras. Mas ainda assim percebo que o espaço é ocupado pelas pessoas que andam, param conversam e as crianças brincam tranquilamente na rua, ainda que eventualmente incomodadas pelos veículos.

De um modo um pouco diferente do Jardim São Carlos, cujos moradores estiveram mobilizados politicamente em torno da questão da moradia, o Boa Vista, ou pelo menos parte dele - visto que a favela ocupa uma grande área no morro -, parece ter sido mobilizado em torno da Igreja, aquela que Luzia mostra em seu vídeo. O pastor deve ter ocupado um papel de liderança importante na comunidade, pois, após sua ida para a Bahia parece que as coisas deram uma certa "esfriada".

Não tenho como averiguar isso neste momento, mas pelo que Luzia conta, muitos moradores parecem viver lá há certo tempo, possibilitando, de certa forma, a participação na construção de uma história coletiva do lugar. Mas isso é somente uma suposição minha. 
Para finalizar, penso que Luzia mantém uma relação bastante positiva com o lugar onde vive. Pelo que pude notar, Luzia sente-se parte de sua comunidade, integrada a ela, embora hoje talvez tenha que passar menos tempo no local em função do trabalho, tal como tantos outros moradores de lá.

Não percebi que o fato dela ter estudado em uma escola especial tenha trazido alguma influência negativa em sua relação com o bairro. Talvez outras pessoas, assim como ela, também tenham tido essa experiência e nem por isso se sentem discriminadas. Infelizmente, é possível que a marca da exclusão não seja uma característica apenas da história de Luzia, sendo também compartilhada por outras pessoas, em outras formas de exclusão, como a prisão. Nessa perspectiva, ser colocado à margem talvez tenha um sentido diferente para essas pessoas; estar de fora talvez não seja vivido como uma exceção, mas uma regra.

\section{b. O tempo vivido no bairro}

\section{A lembrança dos velhos tempos: uma ponte entre o passado o presente e o futuro}

A gravação de Luzia traz muitos momentos de recordação. Ela havia contado, em nossa primeira conversa, que morava no bairro desde que nasceu.

Como já foi mostrado, Luzia iniciou a gravação por sua casa (sugestão minha, aliás), passando em seguida para a rua asfaltada. Logo em seguida, após caminharmos um pouco, Luzia grava um grande sobrado que havia sido sua casa e relata espontaneamente: "Foi aqui que eu morava antes. Cresci aqui e aí meu pai resolveu vender e aí mudamos lá pra cima".

Não sei ao certo se ela já tinha a intenção de fazer uma gravação de sua casa ou a idéia the surgiu quando nos deparamos com ela. De toda forma, penso que o mais importante é que a sua casa lhe serviu como uma referência de memória, assim como a rua de terra, onde estão situadas a casa e a igreja.

Luzia recorda de quando brincava com as irmãs e colegas nessa rua. 
Essa relação entre o espaço e a memória é discutida por Ecléa Bosi (1994) em seu livro "Memória e sociedade: lembranças de velhos", mais precisamente no capítulo "A substância social da memória", na parte em que fala sobre "As pedras da cidade". Ao mesmo tempo em que as pessoas se lembram dos lugares, estes, por sua vez, também trazem recordações a partir de elementos simples como as pedras de um calçamento que podem remeter às experiências da infância.

Os relatos de Luzia são muito breves, ela não se aprofunda em detalhes e não chega a estabelecer uma longa narrativa. O passado parece vir em flashes, em fragmentos. Percebo também como o passado e o presente se alternam em sua fala, como se um puxasse para a lembrança do outro. Nos momentos em que ela recorda dos fatos do passado, ela imediatamente compara-os com o momento presente. Vejo isso ocorrer duas vezes: a primeira quando estávamos na rua de sua antiga casa e a segunda, quando retornávamos subindo a rua.

Na primeira vez, ao trazer para a lembrança as brincadeiras feitas na rua de terra, prontamente ela se remete ao presente e comenta sobre as amigas da infância: "Hoje muitas casadas e as outras encalhadas". Esta não foi a única vez que ela comentou sobre o casamento e este parece ter certa importância para ela. Será um sinal de status? De toda forma, ela não demonstra ver com bons olhos aquelas que não realizaram o matrimônio, chamando-as pejorativamente de "encalhadas".

Quando voltávamos caminhando pela rua, próximos da quadra, pergunto a Luzia o que tem de interessante no bairro. Nesse momento ela se reporta mais uma vez ao passado como contraponto do presente:

Aqui tinha bastante coisa legal, né. Hoje não tem muita coisa não. (...) Hoje não tem mais isso. A turma hoje só serviço, casa e a metade dos meninos se casaram, outros foram presos... 
E mais uma vez ela se refere ao casamento e a prisão como destinos das pessoas do seu grupo. Luzia recorda também que havia um movimento proporcionado pela igreja como as barracas de roupa, os bazares, as campanhas de ajuda, mas que tudo isso também havia acabado. Ela relata também que os jovens que freqüentavam a igreja, hoje não freqüentam mais. Conta que até o pastor foi se embora. Como disse anteriormente, percebo certo ar nostálgico no relato de Luzia, o lamento de algo de bom que se foi e que não foi substituído à altura no presente.

Penso que a razão de seu lamento, de sua nostalgia, esteja relacionada a consciência da dispersão das pessoas que faziam parte de seu grupo, dispersão causada pelo trabalho, pelo casamento e pela prisão, ou seja, aspectos da vida moderna que colaboram para a dissolução da vida comunitária. 0 trabalho obriga o indivíduo a sair de seu local de origem, permitindo seu retorno apenas para o descanso; o casamento pode ser visto também como um elemento de desagregação do grupo a partir do momento em que o indivíduo opta pela vida privada, embora isso seja questionável, principalmente em alguns grupos em que as pessoas continuam convivendo na mesma casa, mesmo após se casarem. De toda forma, penso que para Luzia o casamento de suas amigas parece ser visto como o motivo de distanciamento entre elas. Por fim, a prisão é definitivamente, sem nenhuma dúvida, o processo mais radical de desenraizamento de um indivíduo.

Ao fazer suas breves incursões pelo passado, este parece lhe alertar sobre o presente, sobre o tempo que passou e continua passando implacavelmente - pois ela demonstra ter a consciência de sua idade -, sobre a urgência do que precisa fazer, como casar, ou sobre o que não deve acontecer, como ir presa, tal como ocorreu com seu amigo e seu irmão.

Se eu estiver correto em minhas conjecturas, isso parece mostrar como, de certa forma, Luzia toma para si a responsabilidade sobre seu destino, demonstrando a consciência de suas obrigações para consigo mesma, sem 
entender que são os outros que devem fazer por ela. E esse é um aspecto interessante, pois mostra o lado adulto de Luzia, de responsabilidade, iniciativa e autonomia sobre sua própria vida, muito diferentemente do que se costuma esperar de pessoas consideradas deficientes mentais.

Apesar de Luzia demonstrar essa consciência sobre o que precisa fazer, o que indica, a meu ver, uma postura de autonomia, por outro, tenho a impressão que se sente incomodada por não estar casada, como se o casamento fosse uma obrigação. Tenho dúvidas sobre o que o casamento representa para ela: se é a realização de um desejo pessoal ou se é a necessidade de atender a uma pressão social de seu grupo. De toda maneira, penso que as duas alternativas não são necessariamente excludentes, indicando também que Luzia, ao compartilhar dos mesmos valores e anseios, identifica-se como parte de seu grupo. Por outro lado, ocorre-me uma outra questão: o quanto Luzia se identifica com o grupo e o quanto pode se diferenciar dele, sem deixar de lado sua singularidade e sem ter o receio de se sentir excluída dele. Esta é uma questão que não terei como responder, mas penso ser importante trazê-la mesmo assim, pois entendo que a inclusão/participação em qualquer grupo social/comunidade deve proporcionar aos indivíduos que fazem parte dele, tanto o compartilhamento da identidade grupal, valores e expectativas comuns, como também possibilitar a expressão das singularidades e das diferenças.

Não pretendo com os questionamentos apresentados fazer um julgamento dos atos de Luzia e nem colocar em questão sua autonomia. Foram apenas aspectos que chamaram a minha atenção a partir da gravação realizada por ela.

Para finalizar, gostaria apenas de registrar que algum tempo depois, Luzia comenta que havia se casado com uma pessoa com quem já namorava, também ex-aluno de escola especial, que haviam alugado uma casa e estavam morando juntos em outro bairro. 


\section{MÁRIO}

\section{Primeira Parte}

\section{Conhecendo a Vila Rosa em companhia de Mário}

Conheci Mário há muitos anos atrás, no início da década de noventa, na época em que eu trabalhava como psicólogo na escola especial e em alguns dias da semana também na oficina abrigada. Se minha memória me permite recordar... Não, melhor recorrer aos registros, a prudência me obriga a isso.

Foi entre 1992 e 1993 que trabalhei na oficina abrigada e, quando o conheci, ele já trabalhava no local havia cerca de nove anos, visto que, segundo seu relato, ingressara na oficina em 1984. Neste ano, digo, 2004, ele completa vinte anos de trabalho na oficina abrigada.

Depois de minha saída, voltei a encontrá-lo após meu retorno à escola especial numa das visitas que fiz à oficina abrigada. Após tantos anos, ele parecia não ter mudado nada. Todavia, o meu contato com ele foi retomado somente por ocasião da pesquisa.

Conversei com a professora $\mathrm{C}$., que trabalha na oficina, a respeito dos objetivos e da proposta da pesquisa e, também, sobre os critérios que eu havia estabelecido para escolha dos participantes. Com a sua ajuda elegemos quatro trabalhadores da oficina que apresentavam os critérios exigidos e eram também conhecidos por mim, embora eu não fosse necessariamente conhecido ou reconhecido por eles.

Após uma breve conversa com os trabalhadores sobre a pesquisa, perguntei a eles quem gostaria de participar. Um deles se mostrou bastante interessado, mas disse que não andava sozinho e utilizava transporte particular para ir e voltar da oficina; um outro não demonstrou muito interesse, talvez estivesse ocupado com outras questões. Havia entendido que os dois restantes estavam interessados e disponíveis e o próximo passo 
seria, então, entrar em contato com suas respectivas famílias. Como tive certa dificuldade no contato com a família de um deles e, em função do tempo disponível para a pesquisa, entendi que não teria como esperar e resolvi entrar em contato com o pai de Mário.

Lembrava dele da época em que havia trabalhado na oficina na década de noventa. Fiz o primeiro contato telefônico e marcamos um conversa na oficina para que eu pudesse explicar a proposta da pesquisa. Esperava por um senhor de cabelos grisalhos, de expressão austera e pouco paciente. Para minha surpresa, já por telefone mostrou-se bastante disponível e, depois, quando o encontrei pessoalmente, desfez-se completamente a imagem que eu havia guardado dele.

0 encontro que teria como finalidade a explicação da proposta da pesquisa transformou-se em um emocionante depoimento de quase duas horas. No início da conversa falamos um pouco sobre Mário, mas, aos poucos, quando me dei conta, seu pai falava de suas lembranças, sobre seus sonhos, suas histórias, enfim, sobre sua vida. Confesso que fiquei com uma imensa vontade de registrar aquele depoimento pela riqueza que ele revelava e pelo receio de que ele pudesse se perder no tempo, cair no esquecimento, sem que outros pudessem, tal como eu, tê-lo conhecido.

Após minha conversa com seu pai, retomei a conversa com Mário sobre a pesquisa e combinamos começar na mesma semana.

Como uma breve apresentação de Mário, afinal ele será nosso anfitrião pelos caminhos da Vila Rosa, informo que ele é um jovem de quarenta e um anos, filho de um imigrante italiano, trabalhador da oficina abrigada desde 1984, ex-aluno da escola especial e morador da Vila Rosa há aproximadamente trinta anos. Mora atualmente com seu pai e sua irmã, tendo sua mãe falecido há alguns anos. Tem também um irmão mais novo que é casado e que não reside com eles. Mais informações sobre Mário serão trazidas à medida que formos caminhando em sua companhia, recolhendo pedaços de sua história pelos caminhos do bairro, conhecendo um pouco 
dele por ele mesmo e por seus vizinhos e conhecidos, sobre suas características e hábitos atuais e antigos.

\section{Relato dos encontros ou... A caminhada pela Vila Rosa}

Nossa caminhada pela Vila Rosa começou no dia 03 de setembro, sendo a primeira gravação em vídeo realizada no dia 10 , seguida por mais três encontros (17, 24 e 01 de outubro), totalizando noventa minutos em vídeo e aproximadamente sessenta minutos em áudio.

A seguir realizarei o relato de nossas andanças, contando o que ocorreu em cada encontro.

\section{3 de setembro de 2004 - A primeira conversa}

Sexta-feira feira, poucos minutos antes das três e meia da tarde, os trabalhadores da oficina abrigada já aguardavam ansiosamente pela liberação da saída. Após o toque do sinal, eles saíram e entre eles veio Mário.

Fomos caminhando até sua casa que se situa a mais ou menos um quilômetro da oficina, pouco mais de quinze minutos a pé. A nossa primeira conversa foi gravada em áudio, assim como as outras que se seguiram nesse trajeto que se repetiu durante todos os nossos encontros.

Neste primeiro dia não fizemos nenhuma gravação em vídeo, pois a idéia era conversar um pouco mais sobre a proposta e tentar esboçar um roteiro. Após deixar seus pertences em sua casa, demos uma volta pelo bairro e, assim, comecei a conhecer um pouco da Vila Rosa.

A nossa conversa durante o trajeto entre a oficina e sua casa abarcou vários assuntos. Comecei perguntando seu nome e sua idade e foi então que 
ele me lembrou - pois seu pai havia me contado - que fez aniversário no dia anterior, completando quarenta e um anos.

Mário contou que mora há muito tempo no bairro, desde os dez ou onze anos talvez. Conta que sua mãe era viva ainda e que existiam ali poucas casas e muitas nem eram habitadas. Disse que conhecia muitas pessoas e lugares no bairro como o mercado e o lugar onde corta o cabelo.

Falou que sua mãe no início era espírita, mas depois passou a freqüentar a igreja das Testemunhas de Jeová, voltou para o espiritismo até se tornar evangélica e passar por algumas igrejas.

Mário contou também que freqüenta a igreja evangélica Ministério do Belém, mas seu pai restringe um pouco suas idas quando ele quer ir vários dias na semana. Na igreja evangélica ocorrem vários eventos, festividades, festas para as crianças, para as senhoras, para a mocidade. Disse que foi três vezes na Igreja Sede que fica em São Bernardo e que agora, com a carteirinha de ônibus poderia ir mais vezes com o pessoal da mocidade. Pergunto quem é esse pessoal da mocidade que se referiu e ele explica que é um conjunto da igreja do qual ele faz parte cantando hinos evangélicos. Perguntei se essa igreja era das Testemunhas de Jeová e ele responde que não, que já havia freqüentado essa igreja, mas deixou de freqüentá-la por que ficavam forçando a participação.

Do assunto da igreja ele passou a falar que gostava de fazer artesanato e que havia aprendido com a professora que agora está na oficina abrigada. Citou o nome de algumas pessoas da oficina e aproveitei para the perguntar em que escola havia estudado. Ele então responde que havia estudado na escola especial antes de vir para a oficina abrigada. Recordou 0 nome de algumas de suas professoras e logo depois chegamos à sua casa. Ao chegarmos, ele apontou para uma senhora que trabalhava no bar em frente e disse que ela o conhecia há muito tempo e que, se eu quisesse, poderia conversar com ela. Respondi que poderíamos, sim, conversar com ela, mas em outro momento, quem sabe quando estivéssemos com a 
câmera ${ }^{1}$. Ao chegarmos ao portão de sua casa perguntei 0 que ele conhecia no bairro e ele responde que conhecia o mercado (já havia se referido ao mercado anteriormente), a banca de jornal, a escolinha. E diz ainda:

Tudo pra cá, é tudo como se fosse um círculo. (...) Qualquer caminho eu consigo chegar em casa. Porque eu não consigo nem me perder aqui que é facinho. Meu pai fala que eu não sei, eu sei.

Pergunto se ele pode andar sozinho e ele responde: "Um pouquinho só eu vou. Talvez eu vou, saio a pé, vou a algum lugar e compro alguma coisa e depois eu volto".

Convido-o então para dar uma volta pelo bairro. Ele deixa sua mochila e logo em seguida saímos pelo bairro. Ao retornar diz que vai ao mercado comigo. No caminho pergunto se ele vai ao mercado sozinho e ele diz:

Não, eu desisti. É por causa que, de domingo, eu ia a pé, que meu pai me mandava comprar pão e aí fazia uma fila miserável, eu não agüentava. Fiquei com raiva aí - Ah, eu não vou comprar mais pão - aí eu não comprei mesmo. De sábado eu consegui. Uma vez eu fui comprar pão de sábado, aí foi fácil. Não tinha ninguém. Comprei, voltei.

Mostrou-me ainda o chaveiro e disse que era conhecido por ele, mas não soube dizer o seu nome. No penúltimo dia Mário gravou a conversa que teve com ele. Ao ser perguntado se tem amigos no bairro ele diz que mais ou menos porque fica mais em casa do que na rua.

Logo em seguida entramos no mercado e aproveitei para ver se encontrava pilhas para o gravador. Ele não parecia saber o que queria mostrar exatamente ou, talvez, não quisesse mostrar algo específico, mas apenas o mercado. Como não encontrei as pilhas, logo depois saímos.

\footnotetext{
${ }^{1}$ Na semana seguinte, ela foi a primeira pessoa que Mário se pôs a gravar, voltando a gravá-la em nosso penúltimo encontro, quando ela deu um depoimento um pouco mais demorado.
} 
Na saída perguntei a ele que escola era aquela e ele diz que era para crianças e que seu irmão havia estudado nela, mas ele nunca. Pergunto 0 que ele gostaria de mostrar e ele fala de uma igreja evangélica que não freqüentava, mas que havia ido algumas vezes. Pergunto se sua igreja era próxima de lá e ele responde que sim e que havia uma outra também bem perto dali. Fico um pouco surpreso pela quantidade de igrejas existentes no bairro e mais ainda pelo fato dele dizer que já havia participado dos cultos nelas realizados. Pergunto, então, quantas igrejas ele freqüenta e ele responde:

Ah, as igrejas que eu posso achar. Às vezes eu vou com o pessoal da igreja que eu vou numa igreja. (...) Tem igreja que eu posso ir até sozinho. Ou então eu vou com o pessoal do conjunto, tanto faz. Não faz diferença.

No caminho Mário diz que vai me levar até a farmácia. Não entendi direito o motivo pelo qual ele queria me mostrar a farmácia; pergunto-lhe se é um lugar que ele vai muito e ele diz que não. Emenda a conversa dizendo que havia comprado um guarda-chuvas e surpreso lhe pergunto se havia sido na farmácia e ele diz que não, que foi na loja.

Fomos caminhando pelas ruas, fazendo um longo percurso pelo bairro até ele me dizer que onde estávamos não era mais a Vila Rosa, visto que ela havia ficado lá para cima. Fiquei meio preocupado com o retorno, pois não recordava mais qual era o caminho que tínhamos percorrido, mas pelo visto Mário parecia saber muito bem por onde estava andando até que, em determinado momento do percurso, ao passarmos por uma rua, ele recorda que costumava andar por ali com sua irmã ${ }^{2}$. Diz que seu irmão também andava por ali sozinho, outras vezes ele mesmo. Quando pensei que teria a chance de um depoimento mais pessoal sobre o bairro, Mário avista uma

\footnotetext{
${ }^{2}$ Não sei exatamente se sua lembrança foi provocada pela rua que entramos por acaso ou se, o que parecia aleatório para mim, era um roteiro previsto por Mário. De qualquer maneira, o que importa, o que se tornou interessante é a rua ter evocado o passado ao caminharmos por ela. Aparentemente era o primeiro registro mais pessoal do bairro, pois, até então, a impressão que eu tinha era que havia conhecido somente os “pontos turísticos” do bairro.
} 
trabalhadora da oficina abrigada e vai ao seu encontro. Foi um cumprimento breve e já estávamos na farmácia. Nesse ponto de nossa caminhada ele me pergunta se eu gostaria de continuar ou retornar. Como estava um pouco preocupado em não deixá-lo demasiadamente exausto, sugeri que retornássemos.

Mário explicou-me que um pouco acima ficava uma escola conhecida como Ferraz, onde sua sobrinha havia estudado, mas que depois mudou-se para outra mais próxima de sua casa. Ele tentou explicar-me que havia outras sobrinhas, mas achei um pouco confuso. Depois fez um comentário sobre sua vida escolar, dizendo que ficou um bom tempo sem estudar antes de ingressar na escola especial. Disse que foi para lá quando criança, onde ficou até ir para a oficina abrigada, em 1984.

Passamos por uma rua que ele disse já ter passado sozinho. Pergunto se ele gosta do bairro e ele responde: "Não é que eu gosto daqui, é que eu moro aqui. Até agora eu não mudei". Pergunto se ele gostaria de morar em outro lugar e ele diz responde que em Itanhaém, pois uma vez foi para lá e não queria mais sair de lá. Diz que do bairro sentiria falta dos irmãos da igreja, caso se mudasse, respondendo aminha pergunta. Quando indago sobre esses irmãos, ele explica que são as meninas que ele gosta. Diz também que gosta das palavras que são ditas na igreja. Logo em seguida, pergunta-me se gostaria de conhecer a locadora de vídeos. No caminho para a locadora ele fala sobre a igreja, dos dias da semana em que se realizam os cultos. Ao chegar na locadora ele me mostra um filme, explicando que conta a história de Cristo. Não nos demoramos e logo saímos.

Respondendo a minha pergunta sobre o que existia de bonito no bairro, Mário diz que não sabe, mas que tem muita gente passando, criancinhas, amigos, conhecidos, gente das lojas que o conhecem e conclui: "Só que eu fico mais em casa". Conta que quando não é de sair muito e quando criança ia pra escola de ônibus. Depois, quando ficou mais velho, passou a ir para o serviço, acordando às sete horas da manhã. 
Mário diz que aceitaria fazer uma filmagem de seu bairro, que poderia filmar um amigo e que a locadora poderia ser um dos locais a serem gravados.

Prosseguindo nossa caminhada, chegamos em um local alto, com uma vista privilegiada do bairro. Logo adiante havia um "escadão" que dava acesso à avenida em que estava situada a igreja Ministério do Belém, freqüentada por Mário. Fomos caminhando até a igreja e logo retornamos pelo mesmo caminho. De baixo avistamos a imensa escadaria e, de um lado, o posto de saúde, e, de outro, a escola conhecida como Julieta.

No caminho de volta Mário conta que o serviço na oficina havia diminuído e que agora eles estavam ganhando muito pouco. Explica que o que ganha depende da produção e que metade do dinheiro recebido dá a seu pai. Disse que costuma juntar o dinheiro e no final do ano compra algumas lembrancinhas para as meninas que ele gosta da igreja.

Caminhamos mais um pouco e após algumas quadras chegamos à sua casa. Ao final combinamos de começar na semana seguinte.

\section{0 de setembro - A primeira gravação em vídeo}

Cheguei um pouco antes das três e meia e achei estranho os trabalhadores não estarem no portão aguardando para irem embora, como na semana passada. De toda forma, esperei um pouco até que alguns deles começaram a aparecer. Fiquei conversando com um rapaz que havia participado da Oficina de Fotografia durante uns dez minutos até que surgiu um outro e me contou que haviam sido dispensados nesse dia, vindo apenas alguns poucos para auxiliar em algumas tarefas. Soube então que Mário havia sido dispensado e que, portanto, não estava. Fiquei em dúvida se deveria ir à sua casa, mas por fim acabei indo.

Chegando lá toquei a campainha. 0 cachorro latiu, alguém gritou com ele e ficou por isso mesmo. Instantes depois toco novamente a campainha 
com a sensação de estar sendo impertinente. 0 cachorro late novamente, 0 pai abre a janela e the digo que queria falar com Mario. Pouco depois ele aparece com cara de sono. Explico que estava na oficina abrigada e que fiquei sabendo que haviam sido dispensados. Como ele poderia não estar esperando por mim, pergunto a ele se gostaria de marcar para semana que vem e ele diz que poderia ser hoje. Olha o tempo, vê que está frio e pede para esperar que vai buscar uma blusa.

Não sei porque, mas pensei que Mario não ia querer participar mais da pesquisa. Fiquei surpreso quando ele mesmo disse que poderia gravar. Estava em dúvida também se ele havia entendido o propósito da pesquisa. Tentei montar um roteiro com ele, mas quando eu tentava escrever algo, ele mudava de opinião. Ele decidiu que queria começar pelo bar que fica em frente à sua casa e que gostaria de entrevistar a mulher que o conhece, a mesma que havia sugerido na semana anterior. Ele queria que eu conversasse com ela e que eu fizesse a gravação. Expliquei-lhe que seria ele quem faria isso. Quando já ia partindo para atravessar a rua, pedi para que pensássemos antes o que iríamos perguntar a ela; perguntei-Ihe ainda se sabia o que estávamos fazendo. Explicou que era uma pesquisa com ele sobre o bairro. Quando foi explicar à senhora, disse que era uma pesquisa da oficina abrigada e tive, então, que corrigi-lo. Fiz alguns esclarecimentos sobre a pesquisa e ela concordou, visto que se tratava de uma pesquisa escolar. Expliquei-lhe melhor do que se tratava e ela concordou.

A gravação foi feita em sua cozinha, pois no momento ela estava cozinhando. Embora estivesse ocupada, a Sra. Gisa ${ }^{3}$ mostrou-se muito disponível, risonha e simpática para a gravação. 0 depoimento foi muito breve: ela contou que conhecia Mário, que o considerava um amigo muito especial, que todo dia ele passava por ali justamente na hora em que estava preparando alguma coisa gostosa; disse também que ele contava sobre a oficina e sobre o seu trabalho com artesanato. Em seguida passamos para 0 bar que fica ao lado e fizemos uma gravação com seu marido, o Sr.

\footnotetext{
${ }^{3}$ Os nomes apresentados a seguir são todos fictícios.
} 
Francisco. Sua fala também foi muito breve, dizendo que Mário era "um vizinho meio chato, mas um cara legal, um cara inteligente". A Sra. Gisa completou dizendo que era um bom amigo, filho de italiano e Mário diz "sou amoroso com as meninas". Sr. Francisco corrige, dizendo "perturba as meninas, né"; Mário responde que não mexe, apenas brinca com as meninas e o Sr. Francisco. comenta, "é, essa brincadeirinha ${ }^{4}$...". A Sra. Gisa diz ainda que ele era um paquerador. Finalizada a breve gravação, Mário faz uma tomada da fachada do estabelecimento e o apresenta como uma avícola ${ }^{5}$.

A partir do mesmo ponto ele desloca a câmera, grava a rua lateral e comenta que antigamente, na época em que se mudou para a Vila Rosa, o bairro estava cheio de terra e areia, pois as casas estavam sendo construídas. Durante a gravação passa uma menina que o cumprimenta e ele diz que era uma amiguinha ${ }^{6}$.

Passamos em seguida para a rua lateral e lá foi realizada uma gravação de um depoimento muito interessante. Mário recordou da época em que andava por ali e os garotos e seu irmão empinavam pipa. Disse que não sabia fazer pipa, começou a aprender, mas nunca conseguiu fazer; era 0 seu irmão que sabia. Contou também que era muito rejeitado e teve apenas um amigo e não saia muito de casa, diferentemente de seu irmão que tinha muitos amigos e saia bastante com eles. Saímos dessa rua e caminhamos um pouco até entrarmos numa rua próxima em que ele parou para gravar.

Mário recorda que a rua não existia, que antes era um beco e que até seu irmão sabia disso ${ }^{7}$. Lembra também que na casa branca da esquina vendiam-se doces, mas depois o dono veio a falecer. Recorda que no local em que está situada a escola Julieta era um terreno aberto e vários circos

\footnotetext{
${ }^{4}$ Parece que Mário nem sempre consegue perceber que sua conduta pode estar sendo incômoda para as pessoas, tal como pudemos ver. Para ele se trata de brincar com as meninas, não mexer ou importuná-las, mas, pelo visto, não é dessa maneira que o seu vizinho entende. Esse aspecto será retomado mais adiante.

${ }^{5}$ Depois fui entender que lá se comercializava aves também.

${ }^{6}$ Deu-me a impressão que Mário era uma pessoa conhecida no bairro, pois, vez ou outra, ele era cumprimentado por alguém que passava ou ele mesmo cumprimentava. Algumas dessas pessoas eram conhecidas das igrejas, algumas que ele sequer freqüentava.

${ }^{7}$ Começo a perceber que Mário faz comparações a todo momento, não somente com seu irmão, mas também com as demais pessoas; ele sendo aquele que não sabe e os outros são os que sabem.
} 
que vinham se estabeleciam ali até prefeitura construir a escola. Mas lembra, eram circos velhos.

Mário me pergunta se eu gostaria que ele me mostrasse a igrejinha que ficava ali perto e, então, fomos descendo a rua em sua direção. No trajeto ele se recorda que era o caminho que fazia para ir à oficina, mas acabou mudando o percurso por causa das subidas que tinha que enfrentar.

Antes de chegarmos à igrejinha avistamos uma quadra de esportes; ele conta que algumas vezes já havia jogado nesse local com alguns moleques que o convidavam.

Superada a ladeira de paralelepípedos, chegamos à pracinha em que ficava a igrejinha. É um local alto de onde se pode avistar o outro lado do bairro e a pracinha é também bastante agradável e fresca, protegida pelas sombras das árvores ali presentes. A igreja, por sua vez, é uma construção pequena, provavelmente antiga, mas não sei precisar a data. Apesar de seu tamanho, posso dizer que é bem simpática.

Mário explica que é uma igreja católica, que não a freqüentava e tampouco sua mãe havia freqüentado. Fico curioso para saber o motivo pelo qual ele estava querendo gravá-la e, então, me responde que era para filmar o que ele conhecia, mas, se eu quisesse, poderia filmar também uma igreja evangélica. Todavia, pouco depois, conta-me que, certa vez, foi obrigado pelo pai a assistir uma missa nessa igreja; disse que foi à toa, que foi forçado ${ }^{8}$.

Depois de gravar a igrejinha, Mário faz uma tomada da praça e em seguida faz uma panorâmica de seu bairro, isto é, na verdade, sua intenção não foi fazer, pelo menos inicialmente, uma tomada panorâmica, mas gravar a caixa d'água de seu bairro. Sua intenção foi explicitada verbalmente e ainda me pediu para que 0 auxiliasse com o zoom para aproximar a imagem que estava muito distante. Voltou a gravar a igreja, dizendo que quereria

\footnotetext{
${ }^{8}$ No encontro anterior, Mário contou que havia deixado a igreja das Testemunhas de Jeová porque eles forçavam muito a participação e que ele era contrário a esse tipo de conduta, pois acreditava que a pessoa teria que freqüentar a igreja por vontade própria. Desse modo, é possível compreender como se sentiu por ter sido obrigado pelo pai a ir a uma igreja sem sua vontade. Curiosamente hoje, pelo que conta, seu pai tem restringido suas idas à igreja.
} 
filmar a porta e a escada e para isso aproximou a imagem ${ }^{9}$. Recorda também que certa vez veio à praça, no final de suas férias, e conversou com as mulheres e as crianças que lá estavam e depois não voltou mais ali, pois não era um lugar que costumava ir. Lembra que ali certa vez teve uma quermesse, mas o preço das coisas era muito alto e ele não comprou nada. Não sei qual foi o motivo que o fez lembrar de seu trabalho e começou a contar que montava braçadeiras, depois passou a produzir outras peças, e que, no começo a sua produção era pouca, mas depois começou a produzir bastante, tanto que outros começaram a competir com ele. Mário muda a direção da gravação e sugere gravar a ladeira. Conta que antigamente era de barro e depois veio o calçamento. Este era o caminho que fazia para ir ao serviço, mas depois passou a ir por um outro mais fácil. Mário finaliza a gravação com mais uma tomada panorâmica de seu bairro e, depois disso, retornamos à sua casa.

\section{7 de setembro - Segunda gravação}

No caminho para sua casa pergunto o que gravaríamos e ele responde que serão as coisas que ele conhece. Diz que vai mostrar uma pracinha e uma igreja onde tem muitas pessoas legais que o conhecem. No trajeto fala sobre o seu trabalho, conta que gosta da monitora G. e que espera que 0 ano que vem melhore, pois neste ano não fizeram artesanato.

Antes de chegarmos à igreja, Mário faz uma breve gravação de uma loja de variedades. A dona da loja brinca e pergunta se vai passar na Globo e Mário responde que ela ficará famosa. Ele conta que certa vez comprou um espelhinho nessa loja; a dona pergunta se foi para a namorada e ele responde que não, que havia dado para a monitora da oficina.

\footnotetext{
${ }^{9}$ Nem sempre suas intenções eram claras para mim e nem sei ao certo se eram também para ele. O que posso dizer é que Mário começou a mostrar interesse em explorar os recursos da câmera, mais especificamente o zoom e, quem sabe, o que ele queria mesmo era experimentar. Penso que se dispuséssemos de mais tempo, poderia proporcionar mais experimentações e não me preocupar tanto com o tema proposto.
} 
Após caminharmos poucos metros e virarmos a esquina, chegamos à igreja. Era uma casa e ao lado um terreno baldio, Mário explica que uma era a casa do pastor e a outra era a igreja. Disse que era uma igreja evangélica e ele participava dos cultos realizados às sextas-feiras.

No caminho, já próximo de sua casa, ele pára para fazer uma gravação da vista do local e aproveito para perguntar se, quando andamos pelo bairro, ele se lembrava de alguma coisa de sua vida. Ele diz que se lembra, mas que havia mudado muita coisa. Comenta que muitas pessoas que ali moravam já se mudaram, citando como exemplo uma família que ele conhecia. De sua infância disse que não se lembrava de muita coisa, apenas que andava de bicicleta, mas depois parou de andar porque seu pai não quis consertá-la. Conta que só teve uma amizade cujo nome não se lembrou e, depois que ele se mudou, não teve mais nenhuma; quem tinha muitos amigos era seu irmão, volta a repetir o que havia dito na semana passada. Recorda que havia morado em um apartamento e em casa alugada antes de se mudar para a Vila Rosa. Era uma casa com quintal e que eles nem precisavam sair à rua; ele e o irmão brincavam de qualquer coisa e tudo que pediam ao pai de brinquedo ele comprava. Ele tinha um caminhão de madeira que, as vezes que quebrava, o pai sempre consertava. Ele se lembra também que sua mãe costumava fazer bolo em seu aniversário e enfeitar a árvore de Natal com luzes elétricas, mas depois desistiu de fazer tudo isso. Pelo modo como havia relatado, deu-me a impressão de que ela ainda era viva, mas ele explica que sua mãe havia falecido e mesmo quando viva já tinha desistido de fazer essas coisas. Conta que seu pai levava a todos para passear; não se lembrava ao certo do lugar, achava que era o Palmeiras, mas não estava muito certo.

Depois que chegamos à sua casa, o primeiro local gravado foi a videolocadora. Como sempre, pergunto o motivo pelo qual estava filmando a locadora e ele responde: "é pra gente conhecer a locadora ${ }^{10 "}$. Ele conta que

\footnotetext{
${ }^{10}$ Não deveria haver outro motivo. Era isso mesmo, ele queria que quem assistisse o seu filme pudesse conhecer os locais de seu bairro. Ele provavelmente estava pensando em seus virtuais receptores e, quem sabe, eram os seus colegas da oficina abrigada.
} 
não costumava pegar fitas na locadora porque era sua irmã quem fazia isso. Disse também que a locadora não era muito antiga e que, antes, no local, existia uma loja de "vender qualquer coisa". Era esse modo como ele se referia às lojas que vendiam produtos diversificados. Ele começa a gravar os filmes dispostos na prateleira e diz que lá no fundo não ia querer filmar porque havia filmes pornográficos. Todavia, aos poucos, talvez sem se perceber, aproximava-se do lugar indesejado. Mário conta que gosta de filmes de ação e a balconista diz que a prateleira que ele estava filmando só tinha esse tipo de filme. Pergunto a ela se conhecia Mário e ela faz uma expressão de interrogação; digo então que ele era o Mário e então sorri e diz: "Ah, sim, eu conheço. Ele vem aqui todo dia me ver". Estranho sua resposta porque ele havia dito que quem pegava as fitas era sua irmã e ele então explica: "Eu não venho pegar fita, eu só falo um olá pra ela. É "oi, tudo bem amiga". Eu nunca vim pegar fita aqui, eu nunca fiz inscrição aqui na locadora". Ele continua gravando os filmes e fazendo alguns comentários como "ah, são fitas de amorzinho, (...) essa aqui já vi na televisão, é de um lutador de caratê".

Depois da locadora, fomos em direção à igreja do Belém e no caminho ele diz que quer fazer a gravação de um bar, mas ele se refere como "um negócio de vender qualquer coisa, doces, salgados, cereais, bebidas. Conversamos com o dono do bar e, quando pergunto de onde conhece Mário, ele responde que o conhecia do bairro, que era membro da igreja evangélica e sempre vinha cumprimentá-lo.

O próximo local gravado foi a igreja do Ministério do Belém. Ele conta que é essa a igreja que freqüenta e vem as quintas, sábados e domingos; às sextas vai em outra igreja. Comenta que é conhecido por muitas pessoas, pelas meninas, pelo pastor e pelo presbítero. Após a gravação da igreja ele faz uma tomada da avenida e depois do escadão. No caminho de volta para casa, ele para em frente a uma loja de venda de água mineral e pergunta, como sempre, se poderia fazer uma filmagem. A dona explica que quem poderia dar autorização seria seu filho que não estava no momento. Ela 
pergunta do que se trata, Mário explica e conta também sobre a oficina abrigada, como um local de trabalho para pessoas deficientes, um tipo de treinamento que prepara para trabalhar em firmas e tem monitores e professoras.

Após o esclarecimento, nos despedimos e tomamos o rumo para casa. No caminho retomo com ele a conversa realizada com a dona da loja e recordo que ele havia explicado sobre a oficina abrigada como um local de trabalho para deficientes. Pergunto então se ele era deficiente e ele me responde que tem uma deficiência mental, convulsão e por isso tomava medicação.

Ele conta também que mudou muito depois que começou a freqüentar a igreja, que antes resmungava muito, mas que havia melhorado, embora reconheça que precisa melhorar mais ainda. Disse que seu pai foi chamado na oficina abrigada pela assistente social para explicar que, para ser encaminhado para uma empresa, ele teria que melhorar e que só dependia dele agora. Pergunto em que ele precisaria melhorar e ele diz que precisa parar de brigar. Diz que não é de brigar muito, mas tinha brigado no dia anterior, dizendo ser muito difícil ter que superar coisas que não aceita como, por exemplo, falsas amizades.

\section{4 de setembro - Terceira gravação}

Mário conta que, antes de freqüentar a igreja que mostrou na semana passada, freqüentou uma igreja em São Bernardo, dizendo que lá havia dado muita confusão, pois brigava muito com os irmãos até que sua mãe o desligou da igreja. Disse que os irmãos tinham inveja dele e ele dos irmãos. Pergunto o motivo das brigas e ele conta que era a filha do presbítero. Disse que os irmãos o rejeitavam e não the davam confiança; peço para ele explicar melhor e ele conta que ficava perto das meninas e eles não 
aceitavam isso ${ }^{11}$. Após sua saída dessa igreja, foi conhecendo outras até chegar na atual, na qual se dá muito bem.

Perguntei a ele se já tinha namorado e ele responde que sim, falando de duas mulheres, mas que o namoro com uma delas não havia dado certo. Contou que gostou de garotas de seu bairro, mas que elas já haviam se mudado e que atualmente gosta de muitas pessoas, pelo que entendi, como amigas.

No caminho para sua casa fez uma parada no salão de beleza e pediu autorização para filmar. Pergunto para a cabeleireira há quanto tempo conhecia Mário e ela responde que havia mais de um ano. Ela conta que o conheceu porque ele passava todo dia na rua, parava um pouquinho para conversar e depois ia para casa. Disse que todo dia ele passava por ali. Uma senhora que cuidava de suas unhas disse que conhecia Mário há mais de quinze anos, quando ele freqüentava a academia de capoeira. Mário comenta que foi na época em que sua mãe ainda era espírita e que depois foi pra as Testemunhas de Jeová. 0 ruído do secador de cabelos era muito alto e dificultou nossa conversa, assim como a qualidade do som gravado.

Antes de chegar à sua casa, Mário faz mais uma parada na loja de decoração de festas infantis e grava uma entrevista com a dona do estabelecimento. Ela conta que conhece Mário há mais de um ano, desde o tempo que se instalou no local, que ele passa e fica perguntando o que ela faz. Conta que certa vez ele entrou e Ihe deu um susto; ela ficou nervosa, mas disse que o considerava uma pessoa legal. Sobre o Mário, ela disse que sabe que ele faz artesanato; pergunto se ele não gostaria de contar um pouco sobre o trabalho e a oficina e ele faz uma breve explicação, mas, desta vez, sem fazer referência à deficiência.

Como nas vezes anteriores, Mário passa em sua casa para deixar sua mochila e em seguida saímos para fazer as gravações. Desta vez, retornamos a conversa com a Sra. Gisa em um depoimento mais demorado.

\footnotetext{
${ }^{11}$ Mário diz que eles não aceitavam que ficasse próximo das meninas, mas não consegue perceber que, talvez, ele não aceitasse ter que ficar distante. Ou seja, ele não aceitava cumprir uma regra que contrariava sua vontade e cujo sentido não compreendia.
} 
Ela começa contando que conhece Mário há uns trinta anos, que sempre foi uma pessoa caseira, educado e que nunca foi bagunceiro. É um menino ${ }^{12}$ que é do serviço para casa e à noite vai para a igreja. É bastante respeitado no bairro e muito conhecido. Diz que ele conta sobre seu trabalho com artesanato e que confecciona cestinhas feitas com jornal. Sobre sua época de infância conta que conhece muito pouco porque ele ficava muito dentro de casa. Quando freqüentava a escola especial, ele saia de manhã e voltava à tarde e, por isso, se viam pouco, além disso sua mãe era uma pessoa muito reservada. Passaram a conversar mais há uns seis ou sete anos, desde que começou a ir sozinho para a oficina abrigada. Ela conta que sabe até a hora em que ele chega do trabalho; às vezes a cumprimenta de sua casa, em outras passa em sua cozinha. Disse que já o viu diversas vezes conversando com as meninas da esquina e pisca para ele. Quase no final da conversa ela recorda de um episódio em que viu Mário berrando bravo, chacoalhando o portão de sua casa porque não tinha chave para entrar e seu pai não estava em casa; chacoalhou com tamanha força que conseguiu abrir o portão. Conta que dessa vez ficou assustada com a força que ele tinha.

Terminada a gravação do depoimento da Sra. Gisa, descemos um pouco a rua e fizemos mais duas gravações nesse dia, tomando 0 depoimento do dono do bar e depois com o chaveiro.

No bar, Mário começa perguntando o nome do dono e este responde que é Carlos e que está há três anos e meio na Vila Rosa. Disse que conhece Mário praticamente desde quando chegou ao bairro e que, de vez em quando, pelo menos umas duas vezes por semana ele passa para comprar um chá ou um suco, mas que na maioria das vezes vem apenas para perguntar o preço das coisas, vê se tem algum conhecido e volta para casa. Conta que não o conhece profundamente, mas diz que parece ser uma boa pessoa. Mário recorda que já falou sobre seu trabalho, que fazia artesanato e então o Sr. Carlos lembra que certa vez perguntou-Ihe se tinha tampinha de garrafa, de cerveja ou refrigerante. Mário explica que era para confeccionar

\footnotetext{
${ }^{12}$ Este é o modo como ela se refere a Mário várias vezes em seu depoimento.
} 
porta panelas. Pergunto se ele havia contado que trabalhava na oficina abrigada e Mário responde que já contou diversas vezes, mas o senhor Carlos pareceu surpreso quando ele se referiu às pessoas deficientes. Mário explica que é um lugar que prepara as pessoas para irem para as firmas e que freqüenta a oficina desde 1984. O Sr. Carlos disse que não conheceu a mãe de Mário, mas disse que conhecia o pai como vizinho, que o via guardando o carro e sempre se cumprimentavam sem muita intimidade. Após a conversa, Mário fez uma rápida tomada do bar e em seguida saímos.

Logo abaixo Mário cumprimenta o chaveiro e pergunta se poderia fazer uma entrevista com ele explicando tratar-se de uma pesquisa.

O Sr. Edmilson conta que conhece Mário há muito tempo, desde a época em que soltava pipa com o irmão dele, quando eram crianças. Contudo, não se recorda muito bem de Mário nesse período porque ele não saia muito na rua e, pelo que recorda, seu irmão não gostava que ficasse muito junto porque ele saia correndo. Mário complementa dizendo que pegava a bicicleta, saia correndo e não aparecia mais, sumia. $0 \mathrm{Sr}$. Edmilson lembra que soltavam pipa numa rua um pouco acima e que havia também um campo onde atualmente existe uma escola. Mário conta que não soltava pipa nesse campo, mas recorda que jogou um pouco de bola com o pai e depois parou quando começaram a vir os circos. 0 chaveiro, tal como Mário se refere ao Sr. Edmilson, recorda que certa vez aconteceu um acidente de carro com seu pai, quando este tinha uma Variant verde, ou melhor, cinza, corrige Mário. Aliás, ele comenta não era nem evangélico nesse tempo.

O Sr. Edmilson comenta que agora Mário circula mais e recorda que antigamente ele descia a rua mexendo com todo mundo. Mário diz que só brincava e o chaveiro explica que não queria dizer que ele arrumava confusão, mas brincava, como ele brincou um pouco antes perguntando se havia arrumado uma namorada.

O Sr. Edmilson comenta que mora há trinta e quatro anos no bairro, ou seja, desde que nasceu e fala que o bairro mudou muito nesse período: não existiam muitas casas, as ruas eram de paralelepípedo, havia um beco 
onde atualmente existe uma rua e havia também um campo. Fala de uma foto que sua mãe tem e que mostra apenas uma casa ou outra em sua rua e a parte de trás havia somente eucaliptos.

Após a gravação do depoimento do chaveiro, Mário faz uma breve gravação do muro da escola que fica um pouco abaixo, lembrando que há um tempo atrás ela não era tão fechada porque existia uma grade em seu lugar. Comenta que seu irmão estudou nessa escola e que lá existia brinquedos para crianças e uma quadra. Na seqüência do muro, Mário faz uma tomada da banca de jornal e encerra a gravação nesse dia.

\section{1 de outubro - Quarta e última gravação}

Nesse dia ocorreu um fato interessante; foi a primeira vez que ele pediu para que eu ligasse o gravador, pois tinha uma coisa importante para falar da oficina. Terça-feira recebeu um bilhete pedindo para que fossem providenciados documentos como o RG e o $\mathrm{ClC}$ porque os trabalhadores passariam a ter uma conta no Banco do Brasil. Mário estava contente e disse que, com a conta bancária, poderia guardar o dinheiro para depois poder comprar alguma coisa. Comento que certa vez ele havia contado que gostava de dar presentes para algumas meninas da igreja e pergunto se nesse ano ele faria o mesmo. Mário responde que gostaria de viajar para o interior, mas achava que isso seria difícil porque seu pai não tinha mais idade e condições para isso.

O local a ser gravado havia sido definido no encontro anterior. Mário disse que gostaria de fazer uma gravação no mercado e lá fomos nós. 0 mercado foi um dos lugares mais lembrados desde o início quando se referia ao bairro. Chegando lá conversamos diretamente com o Sr. Messias, proprietário do mercado, que nos autorizou a gravação. Falou que era gerente há trinta e cinco anos. Mário lembrou que há algum tempo uma 
pessoa havia sido assassinada nesse local e o Sr. Messias disse que foi o seu irmão. Não conversamos muito tempo com o gerente e logo Mário saiu gravando o mercado.

Logo no início ele recorda que o mercado era pequeno e depois começou a aumentar com as reformas. Comenta que não veio mais ao mercado porque a fila do pão era muito grande e então acabou desistindo. Além disso sentia falta de ar com a descida ao mercado e subida de volta para sua casa, mas que isso começou a melhorar quando começou a praticar capoeira. Quando criança conta que certa vez sua mãe the comprou um caminhão de plástico e depois não compraram mais nada.

No meio da filmagem ele me pergunta se a informática era importante para as pessoas. Fico surpreso com sua pergunta pelo contexto em que estávamos, mas respondo afirmativamente, explicando que ela ajudava bastante. Pergunta se tanto faz se as pessoas têm problema de leitura e respondo que é possível operar o computador mesmo não sabendo ler. Ele diz então que sua irmã fala que ele não consegue.

Mário filma uma prateleira com artigos de festas e eu the pergunto se ele gosta de fazer aniversário. Ele diz que sim, mas não lembrava de nenhum aniversário, pois isso era passado. Contudo, recorda que sua mãe fazia até cocada. Em seguida filma a prateleira de macarrão, diz que não sabia prepará-lo, mas seu pai sabia. Ele vai andando pelo mercado e filmando os produtos que vai encontrando até sermos interrompidos pelo gerente que me pergunta sobre o que eu estava fazendo o meu doutorado. Ele comenta que estava precisando de ajuda para administrar melhor o mercado, pois estava com muitas dívidas que não conseguia pagar. Começa a falar sobre seu irmão e, então, pergunto se Mário não gostaria de gravar a sua história ${ }^{13}$. Após o consentimento de Sr. Messias gravamos todo seu depoimento. Ao final, ainda fez questão de nos oferecer refrigerantes.

No retorno para casa, Mário recorda que certa vez foi ao mercado comprar bexigas para a festa das crianças que seria realizada na igreja e,

\footnotetext{
${ }^{13}$ O Sr. M. faz um depoimento bastante pessoal sobre sua família e, por entender que se desviava do tema da pesquisa, o material foi deixado de fora.
} 
quando foi pagar, apresentou um real, mas disseram que não precisava pagar. E então ele ficou com as bexigas e com um real. Recorda também de um outro episódio, quando estava numa feira e queria comprar uma fita evangélica que custava doze reais, mas ele não tinha nem três e acabou ganhando a fita de graça. Todavia, a sua sorte não durou muito, pois emprestou a fita para uma mulher evangélica que nunca mais a devolveu.

Ainda nesse dia, para encerrar o trabalho, sugeri a Mário que fizéssemos uma gravação de encerramento. Pedi para que ele gravasse sua mensagem final e depois fomos embora. 


\section{Segunda Parte \\ Trabalho de compreensão, discussão e reflexão \\ acerca do material produzido}

\section{a. O bairro como espaço vivido}

\section{A Vila Rosa}

A Vila Rosa, bairro em que Mário vive, é de difícil caracterização, talvez porque não seja tão homogêneo na sua aparência como a favela de Luzia ou o Jardim das Orquídeas que poderia ser caracterizado como residencial pela observação direta.

Os dados obtidos pelas entrevistas realizadas por Mário não dão muitas pistas a respeito, por exemplo, da condição sócio-econômica dos moradores do bairro. Qualquer inferência a esse respeito, baseada somente na observação do tipo de construção das casas, torna-se muito imprecisa e pouco confiável. É possível supor que a população não se enquadra nos extremos da pirâmide social, isto é, não aparentam ser nem ricos ou tampouco pobres ao extremo.

As casas situadas nas ruas mais próximas são de tipos variados, mas pelo visto há uma predominância dos sobrados. Existem alguns grandes, bem acabados, com revestimento de pedra na fachada ou pintados nas cores da moda, mas há também outros não tão bem conservados, merecendo uma pintura. De modo geral, não são construções improvisadas ou que pareçam ser irregulares.

Um dado interessante que pude notar, é que a maioria das casas tem a garagem na frente coberta por laje ou telhas de amianto e um portão que se fecha até 0 alto. Isto pode indicar que os moradores resolveram adotar um estilo de construção ou que o local exige esse nível de segurança e proteção. 
Há alguns lugares em que predominam as moradias, outros, como na rua de Mário é notável a presença do comércio: bares, papelaria, videolocadora, mercado, chaveiro, loja de decoração de festas etc. No final de sua rua encontra-se uma avenida bastante movimentada, com grande fluxo de automóveis, caminhões e ônibus e que existem muitas indústrias de porte variado. Em uma outra direção, por outro lado, está situado um bairro predominantemente residencial, com construções de alto padrão. Desse modo, como se pode ver, a região é bastante heterogênea.

Dependendo do local de seu bairro é possível notar um fluxo menor de automóveis, diferentemente do que ocorre em sua rua. Não que o fluxo seja grande, mas devido ao comércio e ao acesso para uma via de maior porte, o fluxo parece um pouco maior.

Em relação a presença das pessoas, há alguns locais em que se pode ver crianças e jovens soltando pipa na rua, pessoas sentadas na frente de suas casas, mas, de modo geral, as ruas ficam vazias na maior parte do tempo. Mais especificamente sobre sua rua, a impressão que me dá é que os moradores ficam a maior parte do tempo dentro de suas casas, com pouca convivência entre eles.

Deixando de lado as minhas impressões e descrições, afinal, como o bairro foi retratado por Mário? 0 que gravou, quais foram o lugares? Por que será que escolheu esses lugares, o que eles podem significar ou revelar de seu universo? São muitas as interrogações, não necessariamente para serem respondidas com objetividade e imparcialidade e se chegar a uma verdade. Não é isso que eu pretendo, mas, justamente o contrário; as perguntas surgem como expressão do desejo de diálogo com o outro, como uma tentativa de aproximação e compreensão do olhar que esse outro lança sobre seu mundo, como vive e se relaciona com o seu espaço e quem são os personagens que ali habitam e compartilham de seu cotidiano.

Começarei recordando os locais gravados por Mário que, aliás, não foram poucos. No primeiro dia de gravação ele começa filmando a Sra. Gisa, sua amiga e vizinha, e seu marido, o Sr. Francisco., proprietários de um 
estabelecimento que fica em frente à sua casa - como Mário diz, é um lugar de vender qualquer coisa. Depois grava algumas ruas próximas e uma igreja católica que fica um pouco mais distante. No segundo dia ele grava uma loja de roupas e variedades, uma igreja evangélica e a casa do pastor, uma vista de seu bairro, a videolocadora, um bar e mercearia, a igreja que freqüenta e finaliza com o escadão. 0 terceiro dia começa com o salão de beleza, a loja de decoração de festas infantis, novamente sua amiga Gisa, o bar de sua rua, o chaveiro e termina com uma tomada do muro de uma escola. 0 quarto e último dia ele reserva para a gravação do mercado e o encerramento.

O que todos esses locais podem revelar sobre o mundo de Mário? Como se pode observar, há muitos aspectos em comum entre eles. Poderia começar apontando o fato de muitos serem estabelecimentos comerciais: 0 bar da Sra. Gisa. e do Sr. Francisco, o bar de sua rua, o bar próximo de sua igreja, a loja de roupas, a loja de decoração, o salão de beleza, a videolocadora, o chaveiro e o mercado. Outro aspecto interessante é que muitos deles foram identificados por Mário como "negócio de vender qualquer coisa". Não sei se isso tem alguma relevância para ele; diria apenas que é uma curiosidade e um aspecto interessante a ser observado a respeito de estabelecimentos comerciais de bairro que atualmente têm sofrido a concorrência desproporcional das grandes magazines, shoppings centers e hipermercados.

Além dos estabelecimentos comerciais pode-se notar um interesse especial de Mário por igrejas e esse aspecto é compreensível pelo lugar que a religião ocupa em sua vida e, pelo visto, também de sua falecida mãe. $\mathrm{A}$ expressão de sua religiosidade não se limita somente aos cultos que freqüenta, ela é incorporada em sua fala e comparece a todo o momento em seu discurso; a propósito, é falando de Cristo que ele encerra sua gravação. Voltarei a discutir essa questão um pouco mais adiante.

Se o seu interesse pelas igrejas pode ser facilmente explicado, 0 mesmo talvez não possa ser dito a respeito dos estabelecimentos comerciais. 
Afinal, por que será que ele decidiu gravá-los? Talvez a mesma resposta não sirva para todos eles, mas vejo alguns pontos em comum entre alguns deles. 0 primeiro que merece ser apontado é que pelo menos dois deles se situam no trajeto entre a oficina abrigada e sua casa: a loja de roupas e o salão de beleza. Outros três, a locadora, a loja de decoração de festas e o bar da Sra. Gisa. estão próximos de sua casa, são vizinhos de rua, mas podem ser incluídos como pertencentes ao trajeto trabalho-casa porque são "visitados" no retorno do trabalho. E este é um outro ponto em comum a estes lugares, ou seja, são visitados regularmente por Mário quando este volta para casa. E por que será que Mário os visita com freqüência?

Com exceção da loja de roupas e variedades que Mário visitou certa vez por um interesse específico pelos produtos ali vendidos - refiro-me ao espelhinho dado de presente para a monitora da oficina -, os demais estabelecimentos não oferecem produtos ou serviços de seu interesse. Vejamos: ele não corta seu cabelo no salão de beleza que, pelo visto, parece ser voltado mais ao público feminino; na locadora não aluga fitas e nem sequer é cadastrado, pois quem retira os filmes é sua irmã; na loja de decoração de festas infantis, não percebi nenhuma manifestação de interesse pelo serviço oferecido e tampouco parece querer comprar algo do bar da Sra. Gisa. Mas então, qual é o interesse de Mário por essas lojas?

A resposta que ofereço é muito mais uma inferência de minha parte do que baseado em alguma evidência mais objetiva. Durante as gravações sempre procurava saber o motivo pelo qual ele se interessava em filmar os lugares, algumas vezes perguntando diretamente a ele, porém suas intenções nem sempre pareciam claras para ele mesmo, fato que posteriormente percebi ser um engano de minha parte. Comecei, então, a observar e tentar encontrar alguma explicação e notei que nesses estabelecimentos ele sempre conversava com mulheres. Ou seja, seu interesse não era necessariamente pelos produtos ou serviços oferecidos pelos estabelecimentos, mas por quem era oferecido. Isso me pareceu evidente quando Mário foi filmar a locadora, pois ele havia me dito que não 
alugava fitas, mas a jovem atendente revelou que ele passava por ali todos os dias para vê-la. Ele então se explica dizendo que, de fato, ele não ia para pegar fitas, só passava para dizer um olá para a amiga. Como disse sua amiga, a Sra. Gisa, "ele é paquerador", ou, como ele mesmo diz a seu respeito: "sou amoroso com as meninas". Mas a impressão que eu tenho é que sua intenção não é apenas paquerar, pelo menos na maioria das vezes, pois o que parece buscar é um pouco de atenção e isso parece conseguir dessas pessoas.

Se essa é a razão pela qual ele visita essas lojas, ela não explica sua iniciativa em querer filmá-las. Ou seja, a razão pela qual ele visita suas conhecidas não me parece a mesma pela qual ele resolve gravá-las. E então a pergunta: por que ele grava esses locais?

Como disse anteriormente, a cada lugar que decidia gravar eu the perguntava o motivo e este não me parecia muito convincente, por exemplo, quando foi filmar a igreja católica ele explicou "Pra filmar o que eu conheço"; na locadora ele diz: "Pra gente conhecer a locadora" e, num início de uma gravação, quando the pergunto o que vai filmar ele responde: "Ah, filmar as coisas que eu já conheço". Ou seja, sua intenção primeira era filmar o que ele conhecia do bairro e, também, suponho, era um modo dele apresentar o seu bairro, mostrar os lugares para quem quer que fosse assistir ao seu filme e, assim, poder conhecer o que ele conhece.

Tive certa dificuldade para compreender o espírito de documentário ou reportagem presente em seu trabalho, pois, a minha expectativa era que ele fosse escolher para gravar locais que tivessem algum significado pessoal mais profundo. E, como se pode ver, isso nem sempre ocorreu, pelo menos nas filmagens das lojas. Todavia, um aspecto que não pode ficar sem ser mencionado é que muitos locais revelaram, posteriormente, pelo menos a mim, que, além de "pontos turísticos", guardavam sim um significado pessoal.

0 que pretendo dizer é que nem sempre os locais eram apenas referências do bairro a serem conhecidas, lugares sem relação com sua 
história pessoal, embora, a princípio, aparentasse exatamente isso. Posso dar como exemplo a gravação da igreja católica, um local que eu não entendia o porquê ele queria filmá-la, pois ele não a freqüentava por ser evangélico e não parecia ter qualquer relação com ela. Quem sabe, então, por ser um local conhecido do bairro, talvez uma referência, um "ponto turístico" conhecido por ele e que gostaria de mostrar aos espectadores de seu filme? É bem possível que este possa ter sido o seu critério, pois conta que certa vez até tirou uma foto nesse local. Porém, logo depois ele se recorda que certa vez ele foi obrigado por seu pai a assistir uma missa nessa igreja. Ele não disse há quanto tempo isso teria ocorrido, mas, pelo visto, o fato ainda não havia caído no esquecimento, guardando certo ressentimento dessa época até hoje.

Não acredito que ele tenha escolhido os lugares para serem gravados por estes guardarem um significado especial que ele gostaria de ver compartilhado. Não vejo dessa forma. Para mim, o processo se mostra ao inverso; ele parte para gravar porque são lugares conhecidos por ele e o seu contato com eles, em alguns casos, permite-lhe rememorar acontecimentos passados significativos. Isso ocorre quando grava as ruas próximas de sua casa e então recorda da época em que os meninos soltavam pipa. Sobre este evento, deixarei para comentar um pouco mais adiante.

Além de serem lugares conhecidos por ele, lugares em que encontra pessoas com quem pode conversar, lugares que permitem recordar eventos do passado e revelar significados pessoais, o que mais permitem saber sobre Mário?

Como foi visto anteriormente, é possível encontrar um fio que une o lugares aparentemente sem nenhuma conexão: salão de beleza, loja de roupas, loja de decoração e videolocadora. Nestes casos o fio é o trajeto entre o trabalho e a casa. E em relação aos demais, haverá também alguma conexão? Penso que sim. É possível notar que o bar do Carlos, o chaveiro e o mercado estão todos situados em sua rua, formando uma linha reta. Poderia dizer de outro modo, que o bar e o chaveiro ficam no caminho, são 
locais de passagem para o mercado e este deveria ser o destino final, como ele mesmo contou, o local em que ia comprar pães.

Diferentemente da linha traçada pelo trajeto que o leva para o serviço, a linha formada no trajeto para o mercado é composta por dois estabelecimentos em que os proprietários não são mulheres, mas homens e, mesmo assim, são locais freqüentados por Mário. Sua ida a esses locais não se dá pela necessidade de comprar algo, mas talvez para sair um pouco de casa, conversar com alguém, tal como pode ser observado durante a gravação do bar, no depoimento de Carlos:

Conheço o Mário há uns três anos, praticamente desde quando cheguei aqui no comércio. De vez em quando ele vem aqui comprar um chá, um suco, esse tipo de coisa. (...) Sempre vem aqui, fica perguntando o preço das coisas... Ele vem mais é pesquisar preço mesmo. É comprar que é bom ele... Ah, vai, pelo menos umas duas vezes por semana ele passa aqui pra saber... Ele entra aí, vê se tem alguém conhecido, volta aí pra casa dele.

Os locais gravados por Mário, quando vistos isoladamente, são como estrelas no céu, não passam de pontos sem muito sentido, porém, quando unidos por uma linha formam uma constelação e revelam um interessante desenho de seu universo social. E sobre ele passarei a tratar na seqüência.

\section{Desvendando a constelação social de Mário}

Quem são as pessoas que Mário conhece em seu bairro e o que essas pessoas sabem e dizem a seu respeito? Como é a relação que mantém com elas?

Penso que seja desnecessário repetir que as pessoas que aparecem em seu filme são todas relacionadas ao comércio do bairro. Desse modo, gostaria apenas de ressaltar que não pretendo afirmar que seu universo social no bairro seja restrito a essas pessoas, embora elas possam ser consideradas como representantes desse social e mostrar algo sobre ele. Há 
uma outra parte importante desse universo que não pode ser conhecida por mim que é a comunidade da igreja da qual pertence. Portanto, o que será mostrado a seguir será apenas alguns trechos dos depoimentos feitos pelos participantes de seu filme. E o que será que eles disseram sobre Mário?

Começarei pela dona do salão de beleza. Ela conta que conheceu Mário há um ano por ele passar todo dia por ali: "Parava um pouquinho e depois ia pra casa. (...) Todo dia ele passa aqui, todo dia".

A dona da loja de roupas e variedades não foi entrevistada por Mário, pois ele pediu apenas para gravar a sua loja. Desse modo, não foi possível saber muito a seu respeito, mas um dado interessante é que ela sabia o nome de Mário, pois foi desse modo que se referiu a ele.

$\mathrm{Na}$ videolocadora, a atendente contou que ele passava todo dia ali para vê-la, tal como referido anteriormente: "Ele vem falar oi. Vem, fala oi e vai embora". Contudo, o que me chamou a atenção foi o fato da atendente não saber o nome dele, pois, quando the perguntei se conhecia o Mário, ela fez uma expressão de dúvida.

Da videolocadora atravessaremos a rua e entraremos na loja de decoração de festas infantis. Vejamos o que ela diz sobre Mário:

Conheço o Mário há mais de um ano já. Eu vejo ele passando tudo e depois de um ano que eu entrei aqui que a gente conversa bastante. Passa aqui, fica perguntando o que eu faço.

Quando Ihe pergunto se conhece algo a respeito de Mário ela diz: "Só sei que ele faz trabalho, faz artesanato".

Descendo a rua e chegando ao mercado, o Sr. Messias apenas sinaliza positivamente com a cabeça quando lhe pergunto se conhecia o pai de Mário e diz que sabe "mais ou menos" onde ele morava.

No caminho para a igreja do Ministério do Belém, Mário faz uma rápida gravação de um bar e mercearia. 0 proprietário conta que conhece Mário do bairro e faz o seguinte comentário sobre ele: 
Cumprimenta a gente aqui, vai pra igreja, é membro da igreja evangélica. Vem na parte cedo, vem à noitinha que é o culto. Todo dia que ele passa aí, tem quase como uma obrigação de vim nos visitar aqui e cumprimentar.

A Sra. Gisa, do bar em frente à sua casa, fala em seu primeiro depoimento o seguinte:

Ele adora vir na minha cozinha, todo dia ele vem aqui na minha cozinha, né Mário. O engraçado que ele chega sempre quando eu estou fazendo uma coisa gostosa, né Mário. Ele chega sempre na hora do bolo. Ele chega do serviço umas quatro e meia, cinco horas e vem me visitar.

O que é possível observar a partir desses depoimentos? 0 que me chama a atenção é que todas as pessoas que falam algo sobre Mário, coincidentemente ou não, falam coisas muito semelhantes sobre ele, sobre seu modo de agir, algo quase como um padrão de comportamento. Contam que ele passa todo dia ou, em alguns casos, com uma regularidade até conhecida, como relata Carlos, dono do bar, "pelo menos umas duas vezes por semana ele passa aqui". Mário vem, cumprimenta, conversa um pouco, pergunta algumas coisas sobre preços (no bar) ou sobre o trabalho (loja de decoração) e logo em seguida vai embora. Em poucas palavras, poderia dizer que Mário é visto por essas pessoas como um passageiro, aquele que vem, fica um pouco e vai. Não permanece, não se estabelece.

As pessoas o conhecem como aquele que passa pontualmente, mas sabem pouco sobre ele. Alguns sabem que ele faz artesanato como o Carlos, o dono do bar, a Sra. Gisa, a Sra. Elza, da loja de decoração, mas poucos sabiam que ele trabalhava numa instituição para deficientes e que ele era um deficiente. Mas, então, as pessoas deveriam saber? Por que dizer a eles ou por que omitir? Eu tenho dúvidas sobre isso e me questiono ainda sobre minha conduta, quando lhe pedia para explicar para as pessoas sobre seu trabalho e sobre o lugar em que trabalhava. 
Certa vez conversei com ele sobre o fato dele contar para as pessoas que trabalhava numa oficina para deficientes. Recordo para Mário que ele havia explicado para a proprietária da loja que trabalhava numa associação freqüentada por deficientes e ele responde "e também muitas pessoas demonstram a capacidade", ou seja, deficientes, mas também capazes. Pergunto a Mário se ele era deficiente e ele responde "eu tenho uma deficiência mental". Ele poderia ter respondido, sim eu sou, mas ele disse "eu tenho" e aponta, conscientemente ou não, mas de uma forma muito interessante, a diferença entre ser e ter. Pergunto então o que é essa deficiência mental e ele me responde "convulsão" e conta que toma medicação. Depois complementa:

Deficiência é uma pessoa com problemas, mas nem tanto problema, né. Porque eu_posso ser um pouco nervoso, mas eu sou mais amoroso do que nervoso.

Ele entende a deficiência como problema, mas não de uma forma totalizadora, ou seja, uma pessoa deficiente como sendo somente problema; ele consegue "dialetizar" e apontar que apesar de ser nervoso é também amoroso, competente. E mais do que isso, ele sabe que é preciso fazer esse esclarecimento porque sabe que muitas pessoas compreendem a deficiência somente como limitação e incapacidade.

Mário demonstra um modo bastante peculiar de se relacionar com as pessoas. Pelo que vimos, muitas pessoas o conhecem no bairro, mas sabem poucas coisas a seu respeito. E por que será? Será que não se interessam em saber ou se sentem constrangidas em perguntar? Por outro lado, Mário também sabe pouco sobre seus interlocutores, em alguns casos, não conhece nem o nome das pessoas, pois talvez considere informações pouco relevantes.

Ele circula pelo bairro e vai entrando em contato com as pessoas, querendo conversar com elas, mesmo sem saber exatamente sobre o que. 
Quem sabe, o que busca não seja conhecimento, mas apenas contato, aproximação, atenção.

A impressão que eu tenho é que, depois de muitos anos fechado no espaço de sua casa, quando conquista sua independência, quer experimentar o contato humano. É como nos filmes de Wim ${ }^{14}$ Wenders, quando os anjos caem dos céus e sentem-se descobrindo um mundo novo. Mas a falta de vivência pode muitas vezes trazer problemas porque a atitude em relação aos outros, ao mesmo tempo em que é espontânea, é também ingênua em certos aspectos. Recordo-me do personagem do filme 'Muito além do jardim ${ }^{15}$, interpretado por Peter Sellers que, após viver a vida toda dentro de uma casa, um dia tem a experiência de sair na rua e não sabe nem reconhecer o que the oferece perigo.

As relações sociais são repletas de códigos, regras, convenções e detalhes muito sutis que um estrangeiro, um elemento de fora do grupo, pode demorar para perceber e compreender todos os significados. É como uma situação em que todos riem de uma piada e somente uma pessoa não consegue perceber o motivo da graça. Em certos momentos, a impressão que me dá é que Mário é a pessoa que não entendeu o sentido da piada e por isso não pode compartilhar do riso com os demais.

Mário não percebe que em certos momentos as pessoas se sentem incomodadas com suas atitudes, ou melhor, talvez ele até perceba, mas não compreenda as razões pelas quais uma pessoa se incomodou ou, ainda, não concorde que a sua ação tenha lhe provocado o incômodo. Pelo que pude notar, deve ser comum a Mário discordar da opinião das pessoas quanto a isso e atribuir um outro sentido, ver uma intenção diferente daquela vista pelas pessoas em relação à ação cometida. Recordo-me de sua primeira gravação com a Sra. Gisa e, posteriormente, com seu marido, o Sr. Francisco e do momento em que eles discutiram sobre o modo como Mário se dirigia às meninas:

\footnotetext{
${ }^{14}$ Refiro-me aos filmes “Asas do desejo” (Wings of desire, 1987) e Tão longe, tão perto (Faraway, so close, 1993). Maiores informações sobre os filmes podem ser vistos no site: www.wim-wenders.com. 15 Título original em inglês "Being there” de Hal Ashby, 1979.
} 
Mário: Sou amoroso com as meninas...

Sr. Francisco: Perturba as meninas, né;

M: Brinco com as meninas quando ta aqui, você lembra?

F: Lembro, você mexe com as meninas. Não pode mexer assim...

M: Não é que eu mexo, eu brinco. Não é que eu quero mexer, eu só brinco.

$F: E$, essa brincadeirinha...

Sra. Gisa: Ele é paquerador.

Na opinião de Mário, ele é uma pessoa amorosa, apenas procura brincar com as meninas e não vê problema nenhum nisso porque não está mal intencionado. Já o Sr. Francisco não entende da mesma forma e diz que ele mexe com as meninas.

E qual seria a diferença entre o brincar e o mexer? 0 brincar talvez seja entendido como algo mais próximo do infantil, sem a conotação sexual do senso comum, sem a "malícia" vista pelos adultos, isenta de "segundas intenções", como fim em si mesmo. 0 mexer, por sua vez, não é uma ação ingênua, pelo contrário, sempre é visto como uma ação intencional, um meio para atingir outro fim; visa chamar a atenção do outro, provocar, seduzir. Por isso, não é uma ação que pode ser dirigida a qualquer pessoa, em qualquer situação, porque pode provocar constrangimento. Todavia, Mário não entende porque sua ação pode ser constrangedora, justamente porque não compartilha do sentido atribuído pelos outros à sua ação. $0 \mathrm{Sr}$. Francisco diz "não pode mexer assim" e Mário faz a distinção "não é que eu mexo, eu brinco" e por isso não vê problema, porque não percebe as conseqüências que isso pode gerar.

Em uma outra situação, quando conversávamos com Edmilson, o chaveiro, ocorre uma discussão muito parecida. 
Edmilson: Agora não, mas antigamente descia por aqui e vinha mexendo com todo mundo. $\hat{E}$ chaveiro! $\hat{E}$ não sei quem, ê não sei o que lá!

Mário: Eu só brincava.

$E$ : É, o que eu to falando, brincando, não mexendo, de arrumar confusão, não. Mexer, brincar, como ele brincou agora comigo, se eu arrumei uma namorada...

M: É, brincadeira.

E: Se não sei quem é minha namorada.

M: É, já vi uma namorada aqui, bati um papinho com ela, ainda perguntei o nome uma vez, ih, faz um tempão.

Mário não percebe que, mesmo sem querer, pode estar sendo inconveniente, indiscreto e provocando constrangimento às pessoas.

Como no caso do chaveiro, ele pode tocar em assuntos que talvez as pessoas não estejam dispostas a conversar em determinadas circunstâncias ou, ainda, tornar público o que é da esfera particular. Esse tipo de comportamento é comum em crianças pequenas que, sem querer, causam constrangimento nos adultos por serem indiscretas e pouco sutis justamente por não compartilharem dos códigos ocultos, do que não é ou não pode ser declarado; desse modo, não entendem qual é o problema em anunciar que o rei está nu. Somente uma criança com sua ingenuidade cometeria esta gafe. O grande problema é que esses comportamentos são tolerados nas crianças e muitas vezes as situações criadas por elas são vistos com graça, fato que nem sempre ocorre com os deficientes mentais, principalmente quando se tornam adultos. E então se estabelece um paradoxo porque muitas vezes são vistos e tratados como crianças, mas exigidos e tolerados como adultos. A Sra. Gisa, sua amiga, em sua primeira gravação, dirige-se a ele desse modo, como se ele fosse um menino: "Eu tenho o M. como meu amiguinho, como meu amigão".

Ela chama um homem de quarenta e um anos de amiguinho porque, provavelmente, não o vê como um adulto. Não acredito que o faça com a intenção de lhe atribuir um valor menor, de ridicularizá-lo, mas exatamente 
pelo contrário, por querer tratá-lo de modo carinhoso. Ela procura corrigir-se chamando-o de "meu amigão", empregando um aumentativo, talvez para tentar compensar o emprego do diminutivo, visto como desproporcional, quando aplicado a um homem do porte de Mário. Mas, como disse anteriormente, ela não deve perceber uma conotação pejorativa em seu tratamento porque sua intenção é dar um tom afetivo a sua fala. E dessa maneira ela prossegue em seu segundo depoimento:

Sempre foi um menino caseiro, nunca foi um menino bagunceiro, sempre, assim, educado. Eu conheço ele assim, ele sempre foi um menino educadinho (...) O que eu sei assim... Ele é um menino quieto, não é um menino que, como se diz assim... Que não provoca mesmo ninguém, eu não vejo. Ele é um menino que é do serviço pra casa e depois ele vai pra igreja à noite.

Para a Sra. Gisa, Mário é um menino, ainda que um menino grande e forte que certa vez a surpreendeu com sua força quando abriu o portão trancado de sua casa com um chacoalhão.

Pelo visto, lidar com uma pessoa com deficiência mental adulta se torna uma tarefa difícil porque não sabemos em que lugar devemos situá-lo e, desse modo, experimentamos uma incômoda ambigüidade porque ela não se encaixa em nossas categorias pré-formadas.

Tomo o depoimento da Sra. Gisa apenas como exemplo, sem a intenção de julgá-la ou criticá-la, mas para mostrar que esse tipo de tratamento é muito comum e praticado por muitos de nós, por familiares e profissionais e para dizer que cometemos esses equívocos mesmo quando procuramos estar atentos a isso.

Retornando a questão da tolerância, penso que para a maioria das pessoas se torne mais fácil e menos dissonante tolerar certos comportamentos de pessoas com deficiência mental quando estas são vistas como crianças e não como adultos. Por outro lado, quando são vistas como pessoas adultas, a tolerância parece diminuir, tal como expressa o Sr. 
Francisco quando se refere a Mário: "O Mário é um vizinho meio chato, mas um cara legal, né, um cara inteligente". E novamente a ambigüidade é manifestada de maneira contraditória - chato, mas legal.

Pelos relatos de Mário se observa que nem sempre ele foi aceito, compreendido e tolerado, pois ele relata abertamente momentos de sua vida em que se sentiu rejeitado pelas pessoas. Há dois momentos em que aponta isso, sendo o primeiro ocorrido em sua infância:

Pra falar a verdade eu era muito rejeitado aqui. Meu irmão tinha mais amigo e eu não tinha mais amigo. Só tinha um amigo só, depois não tive mais nenhum. Eu ficava muito dentro de casa. Meu irmão saía direto com os colegas dele. Eu conhecia todos os colegas dele.

O segundo momento é relacionado ao período em que freqüentava uma igreja em São Bernardo. Transcrevo a seguir o trecho em que ele comenta essa experiência:

Mário: Aí eu brigava muito na igreja, deu maior rolo (...) tinham inveja de mim, tinha inveja deles. Só dava confusão. Já briguei com eles, com um monte de irmão já briguei, só dava confusão. Aí, minha mãe desligou da igreja.

Lineu: E por que você brigava?

M: Por causa da filha do presbitero.

L: Como que foi essa história?

M: Eles me rejeitavam. (Silêncio) Esse foi o problema.

$L:$ Como eles te rejeitavam?

M: Não davam confiança.

L: E por que você acha que eles não te davam confiança?

M: Por que eu ficava perto das meninas e eles não aceitavam eu perto delas.

(...) Aí larguei daquela igreja lá. 
Em diversos momentos pude observar uma certa preferência de Mário pela companhia feminina (aspecto que já foi apontado) e também a companhia das meninas. Em relação às mulheres, ele demonstrou isso quando escolheu os estabelecimentos para gravar, mas não foi só nesse momento. Além de considerar a Sra. Gisa sua amiga, ele se refere também a mulheres de outros contextos como pessoas significativas como, por exemplo, a monitora de seu trabalho, muito querida e citada inclusive no encerramento de sua gravação. Ele conta também que tem amigas na igreja em que freqüenta, presenteando inclusive algumas delas no final de ano. Desse modo, é compreensível que prefira ficar perto das meninas a ficar perto dos irmãos na igreja em que acabou brigando. E, como comentei anteriormente, não acredito que essa preferência seja somente porque tenha intenção de paquerar ou namorar e, embora não descarte essa possibilidade, desconfio que procure a companhia feminina porque se sinta mais acolhido entre as mulheres, ou ainda, porque elas o considerem como um menino, tal como a Sra. Gisa e, desse modo expressem uma relação mais maternal e mais tolerante.

Em seu primeiro depoimento ele não explica 0 motivo pelo qual não tinha amigos ou porque era rejeitado quando criança. Já no segundo depoimento ele estabelece uma relação, ainda que um pouco confusa, entre a rejeição sofrida, do querer ficar perto das meninas e das brigas, sem apontar, necessariamente, quais foram os motivos que geraram quais conseqüências, isto é, queria ficar perto das meninas porque era rejeitado pelos irmãos ou os irmãos brigavam com ele porque insistia em querer ficar perto das meninas? Era rejeitado porque brigava ou brigava porque era rejeitado?

A partir de todas essas experiências que foram relatadas, penso que poderia facilmente chegar a conclusão que Mário é uma pessoa que demonstra ter pouca percepção de seus atos e das reações que provoca nos outros, revelando dificuldades no seu processo de socialização, enfim, que poderia ser considerado como um "cara chato", como se referiu o Sr. 
Francisco; a propósito, chatice e inadequações que poderiam ser explicadas pela presença da deficiência mental. Todavia, entendo que é importante suspender as conclusões precipitadas e partir para uma outra leitura.

Durante os poucos dias em que estive com ele, pude acompanhá-lo nas andanças pelo bairro, mas, sobretudo, em seu processo de autoreflexão. Em uma de nossas conversas, como já foi relatado, ele reconhece que tem deficiência mental, que isso pode significar a existência de um problema, mas que não se esgota nisso, pois entende que uma pessoa, mesmo sendo deficiente, pode ser competente apesar de suas dificuldades. Mário reconhece que é nervoso, mas também é amoroso, aliás, mais amoroso do que nervoso.

Mário percebe uma melhora em seu comportamento, pois antes era muito resmungão e atribui essa melhora à sua entrada na igreja. Recorda que deu muita confusão na igreja que freqüentava, mas não atribui a responsabilidade a si, pois entende que os irmãos também não gostavam dele. Todavia, não deixa de apontar o que sua mãe Ihe dissera: "ela falava que eu não sabia me comportar". Ele não discorda disso, tanto que diz ter melhorado, aliás, até sua mãe havia percebido. Mas ele não se acomoda, pois reconhece que tem que melhorar mais. Ele conta que seu pai foi chamado na oficina para conversar com a assistente social sobre as condições necessárias para o encaminhamento dos trabalhadores para as empresas e, pelo que se pode entender, seu comportamento não estava sendo considerado satisfatório. Quando the pergunto em que aspecto ele deveria melhorar, Mário responde que precisa parar de brigar. E isso nem sempre deve ser fácil para ele porque deve entender que nem sempre está totalmente errado. Mas ele considera: "eu tenho que melhorar mais um pouquinho agora. Só ter fé".

A impressão que eu tenho é que ele está atento ao que as pessoas the dizem, recomendam, principalmente as pessoas por quem tem maior consideração como foi sua mãe e, agora, algumas pessoas da oficina abrigada. Aliás, poderia se dizer que o trabalho e a igreja são os locais que 
ele atribui maior valor e significado, pois, como se pode ver, a todo momento se referia ao trabalho ou à igreja. Quando the pergunto do que sentiria mais falta se mudasse do bairro ele responde: "Eu não sei, talvez dos irmãos da igreja. Eu tenho amizade com certas pessoas".

Vejo Mário como uma pessoa em movimento, em busca e em crescimento. Concordo com ele quando diz que há muitos aspectos que precisa melhorar, como qualquer pessoa, mas precisa melhorar não apenas para se adequar satisfatoriamente às exigências sociais. Penso que ele precisa melhorar porque tem condições para isso, tal como tem demonstrado e pode ser exigido no sentido de se tornar uma pessoa melhor para si mesmo.

b. O tempo vivido no bairro: um mergulho no tempo, nas histórias e lembranças narradas por Mário e alguns moradores

Pretendo apresentar a seguir um pouco da história do bairro lembrada por alguns moradores e também um pouco sobre a história de Mário contada por ele e por alguns vizinhos.

\section{A Vila Rosa ontem}

Em nossa primeira conversa, Mário conta que estava com quarenta e um anos comemorados no dia anterior. Pelo que se recorda, deve ter se mudado para a Vila Rosa com cerca de dez ou onze anos.

Estava minha mãe viva naquele tempo, tava os meus pais. Tinha muitas casas que não tava nem morando ainda. Depois nós começamos a morar na Vila Rosa. 
E recorda de como era o bairro naquela época:

Antigamente, quando eu vim morar na Vila Rosa, aqui tava cheio de terra pra fazer obras. (...) Não tinha essa calçada, não tinha quase nada. Só tinha mais areia do que... tinha pouca casa. E começou a fazer obra aqui, obra aqui. Lá era tudo areia (aponta para a rua), onde tem essas casas era tudo terra.

Existiam poucas casas naquela época; se fizermos as contas, deveria ser lá por meados da década de setenta e o bairro deveria estar em pleno crescimento.

No primeiro dia de gravação, quando ele grava as ruas próximas de sua casa, começa a recordar do tempo passado. Depois de ter feito uma tomada do estabelecimento da Sra. Gisa, atravessamos a rua e ele começa gravar uma rua transversal que forma a esquina em que se situa o bar. À medida que ele ia contando, era como se a cena começasse a se formar em nossa frente, como uma grande tela de Portinari ao vivo e em movimento: os moleques olhando para o céu contemplando as manobras de suas pipas, algumas tentando cortar a linha das outras; de repente, um embate e eis que uma delas começa a rodopiar desesperadamente como um avião abatido e, depois, lentamente começa a planar desgovernado, sem rumo em direção ao solo. Embaixo a gritaria, saem meninos correndo de tudo quanto é lado, descem as ladeiras, pulam muros, atravessam as ruas sem olhar, tudo para poder capturar o prêmio que cai do céu. Mas um deles não sai correndo, está encostado no muro, sozinho, apenas olhando o movimento da rua.

Nesta cena imaginária, aproximo-me do menino e the pergunto seu nome e ele responde, é Mário. Pergunto se ele soltava pipa também e ele conta que não; não porque não queria, porque começou a aprender, mas nunca soube fazer uma pipa. Porém, conta orgulhoso que seu irmão sabia fazer pipa muito bem e aponta para um garoto rodeado de moleques montando uma imensa rabiola. Pergunto se ele não tem amigos, ele olha para o lado, faz silêncio como se estivesse pensando e responde: meu irmão 
tem mais amigos e eu conheço todos os seus colegas. Novo silêncio e conta que, na verdade, costuma ficar mais em casa. 0 garoto fica olhando para 0 céu, a câmera se afasta e se desfaz a cena imaginária. Aos poucos os moleques desaparecem, a gritaria se distancia e a rua já está novamente vazia e silenciosa. Os meninos cresceram, alguns se mudaram do bairro e, pelo visto, Mário permaneceu para recordar.

Depois de gravada essa rua, fomos até uma outra em que ele se recorda do tempo em que ela ainda era fechada:

Essa rua aqui? Nem existia. Eu nem passava nessa rua aqui, era um beco. Até o meu irmão sabia disso. Aí depois quebrou uma casa, ai quebrou o beco... Aí ficou isso aqui. Ali ó, sabe o que era? (filma a casa branca de esquina) Era casa de vender doce. Aqui onde eu estou não tinha nada, ninguém passava aqui. Aqui era fechado, aí começou a abrir e fez essa rua aqui. E nós começamos a andar em alguns lugares. Fez a quadra da Independência...

Quem se recorda também do tempo do beco é Edmilson, o chaveiro:

Onde é essa entrada primeira rua aí, aquilo ali, tinha umas casas ali, era só um bequinho que você passava de um lado pro outro, um beco, dessa largura assim. Nós passávamos por ali, se tivesse vindo alguém de lá, não dava pra passar. Depende do porte físico, não passava, não. Onde ia dar no campo, onde é a escola do Independência aí hoje.

Mário recorda que onde está atualmente a escola conhecida como J ulieta era tudo aberto, não existia o muro. Era um grande terreno ocupado por circos, vários circos, mas eram circos velhos. Não sei por que, mas dizer que os circos eram velhos me parece o mesmo que dizer que as uvas estão verdes. Será que o menino Mário não se encantaria com as acrobacias dos trapezistas, não cairia na gargalhada com as palhaçadas, não ficaria fascinado com a coragem do domador diante das feras? 
Quando os circos não vinham, a molecada se divertia do mesmo jeito no terreno, lembra o chaveiro Edmilson, era lá que eles iam empinar pipa. Mas, pelo visto, um dia veio a prefeitura e acabou com a alegria da meninada. Ele conta: "(...) abriram tudo, quebraram as casas ali e abriram a rua. Aí foi quando começaram a construir a escola".

Imagino os meninos do bairro ali, em volta do terreno, vendo as escavadeiras trabalhando, as estruturas se levantando e aos poucos se erguendo a escola. E em vez de ficarem na rua soltando pipa, agora eles teriam é que ir para a escola. E imagino os meninos caminhando para a escola, deixando as bolas e as pipas para trás, tal como fez o menino Pilar do Conto de escola, de Machado de Assis (1999).

Edmilson, o chaveiro, conta que vive no bairro há trinta e quatro anos, ou seja, desde que nasceu, e conta como o bairro se transformou daquela época até os dias de hoje:

É que na verdade, esse bairro aqui, naquela época, aqui era paralelepípedo e casas aqui nessa rua, quando você olhava... minha mãe tem uma foto que você olha daqui pra lá, você vê aqui a minha casa, uma casa ou outra, a casa do Mário tem, e a da japonesa, a Dona Maria japonesa. (...) Eram as únicas casas que tinham aqui. Essa parte aí atrás era tudo eucalipto.

A Sra. Gisa, amiga de Mário, diz que não se lembra de muita coisa, mas conta:

Eu lembro quando não tinha aquela rua, que era tudo fechado. Ali era tudo fechado, tinha a Dona Maria japonesa. Ali eu lembro daquele pedaço ali, que não tinha.

Curiosamente, tanto Edmilson como a Sra. Gisa acabam se lembrando da mesma pessoa, da Dona Maria japonesa. Quem terá sido essa pessoa? Por que será que é tão conhecida e lembrada no bairro, por que foi uma das pioneiras no bairro? Mas infelizmente essas são dúvidas não serão 
respondidas. A única coisa que saberemos dela é que ela se foi do bairro e levou consigo parte da história.

Mas não foi somente a Dona Maria que se mudou, se foi também o amigo de Mário, as meninas que ele disse ter gostado e tantas pessoas mais. Como diz Mário: "Mudou a Vila Rosa, porque não é como antigamente. Era diferente. Tinha muita gente que morava e agora foram mudando, foram pra outro lugar".

\section{Lembranças da história de Mário}

O que ele se recorda da história do bairro é parte de sua história também: a construção das casas, a rua com os meninos soltando pipa, a abertura do beco, a vinda dos circos, a construção da escola, as pessoas que se mudaram e outras que chegaram. A história do bairro foi incorporada à sua porque ele também foi personagem, participante e construtor dessa história coletiva; assim como as pessoas do bairro foram incorporadas à sua história, Mário também passou a fazer parte da história dessas pessoas. Lembrar é incorporar, se apropriar.

Às vezes, sozinhos, não conseguimos recordar de muitas coisas passadas, mas à medida que nos encontramos com os outros e compartilhamos os cacos da memória, tais como fragmentos arqueológicos de uma peça, recompomos a figura que poderia ter se perdido no esquecimento. E esta é uma tarefa coletiva, pois sozinhos corremos o risco de perdermos parte de nossa própria história e esquecermos um pouco de quem somos.

Ao caminharmos pela rua, perguntei certa vez o que se recordava de sua infância e ele me responde que não se lembrava de muita coisa, mas ao continuarmos a conversa foi desfiando os tecidos de sua memória e recordando de muitas coisas preciosas. 0 mesmo ocorreu com o chaveiro Edmilson que disse conhecer Mário desde quando eram crianças, mas não se lembrava de muita coisa dele. Todavia, na medida em que foram 
conversando puderam descobrir juntos muitas coisas que já tinham se esquecido. A Sra. Gisa foi uma pessoa importante também em suas gravações, pois ajudou a recompor parte de sua história com as recordações de Mário que guardava consigo.

Pelo que se vê, somos depositários de nossas próprias histórias e também das histórias dos outros porque, afinal de contas, em certos momentos da vida elas se entrecruzam formando uma emenda que liga uma história na outra; ao puxar o fio de uma, acabamos puxando o fio de outras. E essas emendas são, de certa forma, os vínculos que formamos com as outras pessoas e, ao nos darmos conta disso, podemos perceber que, o que parecia isolado, solitário, na verdade esteve sempre junto.

\section{Recolhendo pedaços da história pelos caminhos da Vila Rosa}

"Da minha infância não lembro muita coisa não". Esta foi a resposta dada por Mário quando the perguntei sobre o que se recordava de quando era criança. Se eu me desse por satisfeito com essa resposta, certamente teria perdido a oportunidade de conhecer muito de sua história. Contudo, isso não iria acontecer porque ele mesmo se encarregou de dar linha a sua pipa, quero dizer, começar a puxar da memória as lembranças que estavam guardadas. E então, logo em seguida, ele prossegue: "Só lembro das coisas que eu fazia na infância, né, andava de bicicleta". Pergunto em que lugar ele andava e ele responde:

Na Vila Rosa mesmo, não posso andar longe. Aqui mesmo, perto onde eu moro. Só que meu pai não quis mais consertar a bicicleta, já era. Era dobrável. Eu brincava dessas coisa de brincadeira de criança, só que eu só tive uma amizade, depois eu não tive mais nenhuma amizade.

Fico curioso para saber de seu amigo, mas ele diz: 
Esqueci o nome dele. Mas tinha muita gente legal na Vila Rosa. Meu irmão tinha muita amizade. Meu irmão era o único que tinha mais amizade (...). Eu tinha uma amizade só, quando mudou eu não tinha mais amizade, fiquei mais em casa.

A primeira coisa que ele se lembra da infância foi de sua bicicleta, aliás, quem é que já teve uma bicicleta e não se lembra dela, do prazer de estar pedalando, deslizando como se estivesse voando... E sua bicicleta era dobrável, que fantástico que isso deveria ser! Mas, para o fim de sua alegria, seu pai não quis mais consertar a bicicleta. Por que será, pois ele conta, em outro momento, que tinha um caminhão de madeira que, às vezes, ele quebrava e seu pai consertava sempre. Por que então seu pai não queria mais consertar a bicicleta se consertava outros brinquedos que se quebravam? Talvez porque a bicicleta deveria lhe dar a dor de cabeça que 0 caminhão não dava. Explico: embora Mário diga que andava somente nas proximidades, ele conta, em nossa conversa com Edmilson, que costumava pegar a bicicleta e sumir. E esse devia ser o motivo pelo qual o irmão não gostava que ele ficasse junto, segundo conta o chaveiro:

Lineu: O irmão dele não gostava quando ele ficava junto?

Edmilson: Que eu me lembro assim, do pouco que eu me lembro... não gostava muito não. Parece que ele saía correndo...

Mário: Pegava a bicicleta e saia correndo e não aparecia mais (risos). Sumia com a bicicleta (risos). Isso eu lembro, eu sumia com a bicicleta.

Mário parecia se divertir com suas fugas, sumiços, mas pelo visto as pessoas de sua família não deveriam achar tanta graça nisso até que... Um dia ele ficou sem a bicicleta e perdeu sua maior diversão. Mas, e os amigos? Dos amigos ele se lembra que só tinha um e, depois dele, mais ninguém.

Mário não se recorda do nome do amigo de infância, mas parece não se esquecer dele, pois já havia falado dele quando gravou a rua em que os 
meninos soltavam pipa, assim como havia dito a mesma coisa sobre os amigos de seu irmão:

Meu irmão tinha mais amigo e eu não tinha mais amigo. Só tinha um amigo só, depois não tive mais nenhum. Eu ficava muito dentro de casa. Meu irmão saía direto com os colegas dele. Eu conhecia todos os colegas dele.

Curiosamente, Mário não só conhecia os amigos do irmão como também sabia o nome deles; pode citar o nome de dois amigos, embora não se lembrasse mais do nome do seu.

Embora dissesse que não recordava muita coisa de sua infância, ao caminharmos pela rua começa a recordar de muitas passagens interessantes:

Não, não lembro de muitas coisas. Uma vez já morei em apartamento, já morei em casa alugada não sei quanto tempo. (...) Antes de vir morar aqui. Eu tinha uma casa que tinha um quintal que nós nem precisava ir na rua. Eu e meu irmão brincava de qualquer coisa. Tudo que nós pedia pro meu pai ele comprava de brinquedo. Eu tinha um caminhão de madeira, às vezes eu quebrava, meu pai consertava sempre. Muita coisa. Minha irmã pediu uma boneca uma vez, acho que eu lembro disso ainda.

A impressão que me dá é que deveria ser uma época muito boa para Mário, pois a sua descrição passa a idéia de um ambiente em que as pessoas estão juntas, um lugar que se bastava em si mesmo, não necessitando sequer ir para a rua, pois tudo que precisavam ou queriam se encontrava ali: o pai que Ihes comprava o que pediam e, se quebrasse, ele consertava; a companhia do irmão com quem brincava de qualquer coisa, a irmã com sua boneca e, não poderia deixar de lembrar, sua mãe ainda era viva.

Minha mãe fazia bolo de aniversário quando eu fazia aniversário, fazia bolo antigamente. Mas agora minha mãe até desistiu de fazer. Ela enfeitava 
árvore de Natal, assim, aquelas elétricas. Mas agora ela não faz mais isso, ela desistiu de tudo isso. (...) Minha mãe. Ela não é de fazer árvore de Natal mais. Também faleceu minha mãe. (...) Quando ela tava viva não quis mais fazer. Isso faz tempo.

As recordações de sua mãe estão associadas a eventos como 0 aniversário e o Natal e a coisas que deveriam ser significativas para ele como o bolo e a árvore de Natal com luzinhas. E, a propósito, existe algo mais inesquecível para uma criança do que o bolo de aniversário e a arvora de natal?

Mário lembrou de sua mãe em vários momentos, aliás, diria que ela não Ihe sai do pensamento. Quando Mário estava fazendo a gravação do supermercado ele lembra que certa vez sua mãe lhe comprou um carrinho, um caminhãozinho de plástico e depois não fizeram mais compras ali porque ele sentia dor de cabeça e falta de ar por causa da caminhada.

As recordações de sua mãe ficaram muito associadas também à religião:

Num tempo a minha mãe era espírita, agora nem evangélica (incompreensível)... Depois largou do espiritismo, deixou a Testemunha de Jeová, foi pro espiritismo de novo, mas depois foi pro evangelismo e ficou até o fim. (...) Aí depois já fui quadrangular com minha mãe visitar. 0 Sermão da Montanha a minha mãe foi até o fim visitar aquela Igreja, lá em São Caetano.

E devem ser recordações significativas porque Mário a acompanhava nessas peregrinações pelas igrejas e religiões.

Aí eu fui na Quadrangular, já fui na, deixa eu ver, na Sermão da Montanha com a minha mãe, lá pra virada do ano, acho que foi duas vezes. Só que quem ia mais era minha mãe no Sermão da Montanha. 
Esta peregrinação chama a minha atenção porque me dá a impressão de que estavam à procura de algo e não pararam até encontrar. E pelo que ele conta sua mãe encontrou o que buscava na igreja do Sermão da Montanha. Tal como sua mãe, Mário empenhou-se também em sua busca até encontrar parada na igreja Ministério do Belém que freqüenta atualmente.

Ainda sobre sua mãe, ele recorda que ela fazia programas religiosos no rádio:

Já escutei a minha mãe falando na emissora, chama rádio L. Ela fazia dois programas, só que ela não fazia todo o dia. (...) Ela não ganhava nada. Acho que ela não cobrava das pessoas não. Acho que ela fazia mais pra Jesus. $E$ fazia mesmo. O programa dela chamava "Orar sem cessar". Cessar quer dizer, não desistir e não deixar de orar. Tem que orar sempre pra Jesus Cristo.

Chama minha atenção como a religião é presente a todo o momento para Mário, assim como faz uma associação muito estreita entre a religião e a lembrança de sua mãe.

Atualmente ele freqüenta duas igrejas, uma delas, como ele explica, na condição de visitante. Na igreja do Ministério do Belém ele vai as quintas, sábados e domingos e, na outra, somente às sextas.

Mário parece ter encontrado seu lugar na igreja e, pelo que conta, a impressão que me dá é que nesse local ele se sente confortável e, sobretudo, sente que é aceito pelos irmãos. A igreja evangélica oferece várias atividades e entre elas o conjunto musical do qual ele participa cantando. Nesse sentido, a igreja passa a ser um local de convívio social, um local em que não se sente discriminado ou rejeitado e, além disso, torna-se um espaço em que pode realizar o que gosta, ou seja, cantar.

Todavia, como ele conta, sua experiência com as igrejas nem sempre foi tão tranqüila. Tal como já relatado anteriormente, teve muitos problemas em sua primeira igreja até que sua mãe resolveu não levá-lo mais lá. Mário 
conta que não teve uma experiência muito positiva com a igreja das Testemunhas de J eová:

Não, eu não sou mais. Eu era. Eles ficavam forçando muito. Forçar é errado. Não pode forçar, vai por vontade própria. Não vai por vontade da outra pessoa. Ninguém é obrigado a ir quando não quer ir. É pecado isso. Não pode forçar as pessoas. Mas convidar, tudo bem, isto está certo. Fazer um convite... tá certo, mas ficar forçando, não pode.

Mas não foi somente nessa igreja em que se sentiu forçado, pois tal como foi relatado anteriormente, certa vez Mário foi obrigado por seu pai a assistir uma missa numa igreja católica. Curiosamente, hoje o embate não se dá porque é forçado a ir a alguma igreja, mas, pelo contrário, porque é restringido por seu pai de ir a todos os cultos que ocorrem durante a semana.

\section{Do passado ao presente}

A liberdade que Mário tem hoje de transitar sozinho pelo bairro é algo relativamente recente em sua vida. Na conversa com sua amiga Gisa, eles recordam que Mário começou a andar pelo bairro há cerca de seis ou sete anos, desde que passou a ir e vir sozinho da oficina abrigada, pois, até então, era seu pai quem o levava e o trazia, conforme se recorda a Sra. Gisa: "Isso mesmo, porque o pai dele levava ele, levava e ia buscar. Ele lembro direto disso aí, seu pai tirava o carro e ia te buscar você e trazer você".

A Sra. Gisa conta que foi por volta dessa época, depois que ele começou a andar sozinho que começou a conversar mais com ele:

(...) a gente não tinha muito contato. A mãe dele era muito reservada também, então a gente não tinha muito contato, você entende? Agora, de 
uns tempos pra cá que a gente conversa mais. Acho que de uns seis ou sete anos pra cá, né, Mário?

Ela diz se lembrar muito pouco de quando ele era criança, pois quando o conheceu já não era tão pequeno assim, tendo por volta de dez ou onze anos, além disso, não tinham muito contato porque Mário ficava muito dentro de casa, como ele mesmo já havia dito.

Mário não era uma criança de ficar brincando na rua e, pelo que contou, quando seu único amigo se mudou foi então que passou a sair menos ainda. E é desse modo que Edmilson se recorda dele também:

Conheço o Mário do tempo de... Nós soltávamos pipa, eu soltava pipa com o irmão dele. Ele talvez, naquela época, não me lembro muito bem, mas ele não saia muito na rua.

Pergunto a Mário se ele ficava mais em casa e ele responde:

Ficava mais em casa. Mas quando minha mãe saia, meu pai saia, minha irmã saia, ficava numa boa em casa e comia tudo que eu podia (risos). Eu nem ligava. E eu era muito acostumado com televisão. Agora meu pai não deixa mais.

Em nossas conversas feitas em outros dias Mário voltava a dizer que ficava mais em casa, que não era de sair muito de casa, a não ser para ir à escola:

Quando eu ia pra escola fui pegar o ônibus lá embaixo, lá no posto. E ia pra escola. Aí tudo passou, aí eu fiquei só em casa. Só ia pro serviço. Eu levanto 7 horas da manhã e vou pro serviço.

Seu depoimento pode parecer um pouco confuso porque ele acabou condensando algumas informações. Num primeiro momento ele conta que ia pegar o ônibus escolar para ir à escola, dizendo também que nesse período 
só ficava em casa. E então o tempo passou e agora não vai mais à escola, só vai pra o serviço.

Se em tempos remotos seu universo social parecia se resumir ao ambiente da escola especial e a sua casa, atualmente, pelo que se pode ver, ele vem aos poucos ampliando os seus relacionamentos, seus conhecimentos pelo bairro, desde que deixou de ser acompanhado pelo pai ao serviço. Todavia, pelo que pude entender, não significa necessariamente que ele passe muito tempo na rua no período em que não se encontra no serviço. Ele diz "eu não chego a conversar com eles sempre ${ }^{16}$. Eu fico mais em casa do que ficar aqui na rua". E sua fala parece fazer sentido e confirmar o que vinha sendo cogitado a respeito dos seus contatos no bairro. Isto é, os contatos com as pessoas dos estabelecimentos comerciais é feito somente no momento em que está retornando do trabalho, porque depois, provavelmente ele não deve mais sair de casa até a hora de ir para a igreja.

Atualmente é indiscutível que seu universo social se encontra muito mais amplo do que quando era criança, pois ele circula muito mais pelo bairro e conhece muito mais pessoas do que em épocas anteriores. Todavia, por tudo que pudemos ver, os ambientes socialmente mais significativos para Mário continuam sendo a oficina abrigada e, agora também, a igreja, pois são nesses locais que ele mantém as relações sociais mais significativas.

Em uma de nossas conversas caminhando pelo bairro lhe perguntei se ele pudesse, se gostaria de morar em outro lugar e ele responde que sim, em Itanhaém porque certa vez foi para lá e não queria mais voltar. Pergunto então, se mudasse, do que sentiria mais falta e ele responde: "Eu não sei, talvez dos irmãos da igreja"...

Em nosso último dia, após a gravação do mercado, propus a Mário que fizéssemos um encerramento.

Sugeri que fôssemos ao local do escadão por oferecer uma vista panorâmica. Lá chegando, perguntei a Mário se valeu fazer as filmagens, se

\footnotetext{
${ }^{16}$ Ele se refere aos amigos do bairro.
} 
ele tinha aproveitado e ele responde que sim. Disse que gostou de filmar a locadora, a conversa com sua amiga Gisa, os seus amigos e os amigos da igreja. Peço então que registre sua mensagem final. Mário começa a falar da monitora da oficina e em seguida faz um discurso religioso sobre Jesus, Satanás, salvação e depois volta a se referir ao pessoal da oficina. Seu discurso pareceu um pouco confuso e então perguntei o que ele gostaria de falar para encerrar a gravação. Mário volta a falar da monitora e de Jesus ${ }^{17}$ e finaliza da seguinte forma:

A gente pensa que o mundo reserva coisa pra gente, mas não, tão tudo enganado. O mundo não reserva nada pra gente do que presta pra nada. $O$ que reserva pra gente é Jesus Cristo, que fala assim na biblia: reconcilie com Jesus Cristo e faz a sua escolha: o inferno ou o céu, precisa escolher, o céu, ou, então, fala assim, escolha Jesus por amor ou pela dor. Se não acontecer nessas duas, aí cai no inferno. É Jesus que fala pela minha boca, não sou eu não. Pode fechar a câmera, vamos embora.

\footnotetext{
${ }^{17} \mathrm{E}$ é compreensível que ele quisesse finalizar falando da monitora e de Jesus porque afinal eles são os elementos que sintetizam e simbolizam os dois universos sociais mais significativos para Mário: a oficina e a igreja.
} 


\section{MÁRCIO}

\section{Primeira Parte \\ Conhecendo o J ardim das Orquídeas em companhia de Márcio}

"Tem vinte anos que eu moro aqui. É um lugar sossegado e legal pra morar. Não tem tantos assaltos, não tem tanta violência aqui. É uma paz, traz uma paz interior muito grande morar aqui".

Foi assim que Márcio começou apresentando seu bairro no primeiro dia de gravação, primeiro passo de uma viagem pelo espaço das ruas, das casas e pelo tempo da história, das lembranças dele e de sua mãe.

Mas, quem é Márcio? Apresento, então, ao leitor o nosso guia e anfitrião: é um jovem de vinte e cinco para vinte e seis anos, ex-aluno de escola especial e atualmente um "aprendiz" de uma oficina abrigada. Ele é filho da senhora Floriza, viúva, que tem como filhos, além de Márcio, mais duas filhas: a mais velha que é casada e mora no mesmo bairro e a mais nova que mora na mesma casa com a mãe e o irmão. A história de sua família deixarei que eles mesmos contem, mas um pouco mais adiante. Gostaria de contar agora, muito brevemente, o motivo pelo qual o convidei para participar da pesquisa e, logo em seguida, irei relatar como foi se dando a nossa viagem pelo bairro.

\section{Alguns anos atrás...}

Fiz minha segunda inserção na educação especial em 2000. A primeira, tal como relatei anteriormente, foi no início da década de noventa. Foi, então, nessa segunda experiência, trabalhando como psicólogo de uma escola especial, que conheci Márcio. Ele era aluno de uma sala composta por jovens que estavam sendo preparados para o mercado de trabalho. Fizemos muitas atividades juntos e uma das últimas, antes de sua saída da escola, 
foram as visitas para as casas dos alunos utilizando o transporte público ${ }^{1}$. Visitamos inclusive sua casa e foi dessa vez que conheci seu bairro pela primeira vez. Márcio foi encaminhado para uma oficina abrigada em 2002, ano que se desligou da escola especial.

Depois de sua saída encontrei-o estagiando numa repartição pública. No início deste ano de 2004, pensei em convidá-lo para participar da pesquisa, mas como ele estava envolvido com alguns problemas de ordem pessoal, entendi que seria melhor pensar em outra pessoa. Voltei a encontrá-lo na oficina abrigada quando já estava realizando as gravações do bairro de Mário e, como ele se mostrou interessado, decidi convidá-lo novamente para participar.

Posso dizer que um dos motivos que me levou a cogitá-lo como participante da pesquisa foi a afinidade criada desde a época da escola especial, levando-se em consideração que ele apresentava também os critérios necessários para a pesquisa como, por exemplo, a independência no ir e vir.

\section{Relato dos encontros ou os passos pelo J ardim das Orquídeas}

Nossa primeira conversa aconteceu no dia 04 de novembro de 2004, a primeira gravação ocorreu no dia 12 de novembro e a última no dia 14 de dezembro, totalizando seis encontros (cinco para gravações) e um pouco mais de duas horas de filmagem. A seguir, passo a relatar como ocorreu essa trajetória.

\section{4 de novembro - A primeira conversa}

A nossa primeira conversa "oficial" ocorreu após Márcio aceitar o convite para participar da pesquisa e sua mãe autorizar sua participação ${ }^{2}$.

\footnotetext{
${ }^{1}$ Como esta experiência foi relatada no início da pesquisa, tomo a liberdade de não explica-la novamente.

${ }^{2}$ A consulta à mãe foi feita a pedido do próprio participante.
} 
Neste dia acompanhei-o até sua casa e fomos conversando durante 0 todo o trajeto, desde a espera no ponto de ônibus até chegar em sua casa. Com a permissão de Márcio, a nossa primeira conversa foi gravada, assim como as demais que fomos realizando em outros dias.

Começamos a conversa de uma maneira um pouco formal e, tal como em uma entrevista, pedi para que ele falasse seu nome e sua idade, mas logo depois já estávamos no espírito do bate-papo.

Márcio contou que estava na oficina abrigada desde 2002 e que há pouco tempo está estudando à noite, no programa de alfabetização de jovens e adultos. Ao retomarmos um pouco a sua trajetória pela educação especial, ele recordou que estudou em duas escolas especiais. Na primeira, desde pequeno e, na segunda, desde os dezessete anos, quando foi transferido para a escola que nos conhecemos. Antes de seu ingresso na escola especial, ele conta que havia estudado em escola comum.

No trajeto, Márcio contou também que começou a andar sozinho há poucos meses, pois até então sua mãe o acompanhava para ir e voltar do trabalho. Como ele mesmo diz: "A minha mãe nunca me soltou". Sua chance surgiu quando passou a estagiar na repartição pública em que sua vizinha e colega, também ex-aluna de escola especial, já estagiava. Foi então que sua mãe deixou de acompanhá-lo, por confiar na companhia da colega. 0 que a mãe soube, tempos depois, é que a colega havia sido transferida e que, desde então, Márcio estava indo sozinho ao trabalho. Depois disso, a mãe deixou de acompanhá-lo.

O barulho do ônibus dificultava um pouco a nossa conversa, assim como a qualidade da gravação. Após descermos, caminhamos uns quinze minutos até chegar em sua casa. No caminho ele me mostrou a escola regular onde estudou, mas disse que não se lembrava de muita coisa, pois nunca mais havia entrado nela. Contou também que morava no bairro há mais de dezessete anos ${ }^{3}$ e que antes havia morado na Paulicéia, um bairro de São Bernardo.

\footnotetext{
${ }^{3}$ Esse dado foi depois contestado pela mãe.
} 
Após chegarmos a sua casa, ele se desfaz de seus pertences para que possamos caminhar mais um pouco pelas ruas do bairro. Durante a caminhada, pergunto a ele se conhecia muitas coisas no bairro e ele responde que sim. A respeito do social, ele relata que tem mais conhecidos do que amigos no bairro e que costuma sair com o pessoal da oficina abrigada que também freqüenta a sua casa nos finais de semana. Sobre sua experiência profissional, relata que o Departamento ${ }^{4}$ foi a melhor escola, que lá encontrou amigos. Nesse local Márcio tinha como responsabilidade varrer o pátio.

Ele conta, também, que na época em que estudava na escola especial não costumava andar muito pelo bairro, era "de casa para a escola e da escola para casa", pois a mãe não o deixava sair muito.

Márcio fez também alguns relatos breves de sua infância, contando que costumava empinar pipa e andar de bicicleta.

Após nossa primeira caminhada pelo bairro, retornamos à sua casa e encontramos sua mãe, com quem conversamos bastante.

Sra. Floriza, mãe de Márcio, fez um relato da trajetória escolar do filho, o ingresso dele na educação infantil, o início no ensino fundamental e a dificuldade em mantê-lo na escola regular, a ida para a escola especial e sua permanência até ir para a oficina abrigada. Fez muitas críticas, tanto à escola regular quando à escola especial que, na sua opinião, proporcionou pouca aprendizagem ao filho. Por fim, contou que Márcio voltou a estudar por vontade própria e que está indo muito bem.

Quando resolvemos encerrar a nossa conversa já havia escurecido. Estávamos no horário de verão, mas as horas tinham passado despercebidamente. E assim foi a nossa primeira conversa.

\footnotetext{
${ }^{4}$ Modo como se refere à repartição pública que estagiou.
} 


\section{2 de novembro - A primeira gravação}

Neste dia fui direto para sua casa, diferentemente da vez anterior em que me encontrei com ele na oficina abrigada, pois, de acordo com Márcio, ele estaria vindo de um outro lugar, ou melhor, do local onde estava fazendo um curso.

Cheguei alguns minutos antes dele e sua mãe convidou-me para entrar. Enquanto aguardava por ele, ela ofereceu-me café e ficamos conversando sobre sua permanência na escola especial. Sra. Floriza fez novamente críticas à escola, principalmente quanto ao conteúdo que foi oferecido a ele durante todos esses anos.

Após a chegada de Márcio, saímos para fazer a primeira gravação. Propus que fizéssemos um roteiro, mas notei certa dificuldade em estabelecermos uma seqüência. Desse modo, tal como nas experiências anteriores, deixei que durante a própria caminhada fôssemos discutindo 0 que seria gravado.

Começamos ali, pela rua da casa de Márcio. Antes de ele iniciar a gravação, passei alguns instruções mínimas sobre o manejo da câmera, assim como a recomendação para que a mantivesse firme, sem tremores ou movimentos bruscos.

Após a primeira tentativa, retornei a fita para que ele pudesse ver 0 resultado da gravação. Curiosamente, o que mais Ihe chamou a atenção não foi a imagem produzida, mas a gravação de sua fala, mostrando-se muito crítico em relação ao resultado. A fluência de sua fala é mais lenta em virtude da paralisia cerebral, porém o conteúdo é totalmente compreensível. Esta não foi a única vez que fez ressalvas à sua fala e a sua voz, contudo concordou em continuar explicando o que estava sendo gravado.

Em relação ao manejo da câmera, esta foi feita somente com a mão direita, visto que a esquerda apresenta comprometimento em função da 
hemiplegia ${ }^{5}$ causada pela paralisia cerebral. Desse modo, para utilização de algumas funções da câmera Márcio precisou de minha ajuda.

Enquanto Márcio fazia imagens de sua rua, relatou que gostava de seu bairro, que as pessoas eram legais e que umas ajudavam as outras quando podiam. Disse que é um lugar sossegado e que não tem tantos roubos, assaltos ou violência. Após a gravação da primeira cena na sua rua, perguntei o que mais existia de interessante e Marcio referiu-se à praça.

A praça é próxima à casa em que moravam e que, por sua vez, é vizinha da casa da amiga de sua mãe que, também, tem um filho na escola especial.

De frente à sua antiga casa, pode-se avistar a praça citada e a igreja que se situa ao alto, que foi também gravada por Márcio. Nesse dia, aliás, fizemos ainda a gravação da represa Billings e, no retorno, a escola em que ele estuda atualmente.

Sobre sua antiga casa, Márcio relata que foi lá que passou a maior parte de sua vida, inclusive a infância, e que se mudou depois do falecimento de seu pai, quando ele tinha por volta dos dezesseis anos. Ele conta: "Depois que meu pai morreu nós tivemos que mudar daqui pra ter um seguro de vida, que é alugue ${ }^{6 "}$.

Em relação à praça, conta que era lá que brincava, ou melhor, "ralava mais do que brincava", explicando que naquela época se ralava porque caía muito. Na conversa que foi posteriormente gravada com sua mãe, ela conta que Márcio usava um aparelho na perna quando era criança, mas que isso não o impedia de sair correndo para escapar da surra que ia levar por conta das suas fugas de casa. Ainda na praça, ele faz uma gravação da quadra ali existente, contando que é ali que passa a maior parte do tempo e que era ali que costumava jogar bola ${ }^{7}$. Lembrou também que era ali que andava de

\footnotetext{
${ }^{5}$ É assim denominada quando a paralisia cerebral afeta um dos hemisférios do corpo, no caso de Márcio, seu lado esquerdo.

${ }^{6}$ Como foi explicado em outros momentos, após o falecimento do pai, a família se muda para outra casa - a que a mãe tomava conta para um conhecido que foi para o Japão - e, assim, pode alugar a casa onde moravam.

${ }^{7}$ Pelo que Marcio relatou posteriormente, pareceu-me pouco provável que ele freqüentasse a praça e a quadra, visto que ele próprio relatou que circulava pouco pelo próprio bairro e que tinha poucas
} 
bicicleta. Perguntei se ele andava apenas com uma das mãos e ele responde: "Com as duas. Depois que eu operei, aí estragou".

Fizemos uma primeira tomada da igreja a partir da sua antiga casa, uma segunda de sua fachada e finalizamos com a gravação de seu interior. Conta que se trata da igreja de Nossa Senhora do Guadalupe e que foi nela que fez sua Primeira Comunhão e a Crisma. Conta que nessa igreja sente muita paz e diz: "quando eu me sinto aflito ou com qualquer problema de desassossego, eu venho pra cá pra pensar e refletir". A igreja estava vazia quando entramos; o silêncio imperava e o frescor de seu interior era um conforto para aqueles que vinham se refugiar do calor do sol.

Márcio fez uma tomada do Cristo pregado na cruz e das figuras presentes nos vitrais. Ao gravar as imagens, sua fala sobre Nossa Senhora me chamou atenção. Ele diz: "Essa é a Maria, mãe de deus. Essa é a santa que mais me acompanha no dia que eu tenho mais assuntos pesados pra resolver. Ela que me acode".

Ao sairmos da igreja, fomos caminhando pelas ruas do bairro até avistarmos uma parte da represa, uma área cheia de árvores conhecida como J ardim Las Palmas. Ele pergunta se eu gostaria de conhecer e digo que sim. Pensei comigo, não poderia deixar de conhecer, pois foi uma surpresa descobrir que poderíamos chegar andando até a represa que estava ali, de repente, no meio do bairro.

Ao iniciar a gravação, Márcio recorda que costumava vir muito com seu pai nesse lugar para pescar, mas depois que ele faleceu, não veio mais. Comentou também sobre a falta de tratamento da água, dizendo que 0 esgoto era despejado diretamente na represa, mas disse que, com 0 tratamento, essa situação iria mudar.

Quando estávamos indo embora ele comenta: "Aqui é o fim do mundo". Sua fala me pegou de surpresa. Parei para pensar e concordei. De fato, ali era o fim do mundo. Era ali que a cidade subitamente terminava, era o limite. Ele continua: "É mais interiorzão, é sossegado, tranqüilo. Se quiser 
morar aqui, eu recomendo. Mas não sei se tu vai gostar. Aqui é outra... é a mesma parte, mas é o lugar menos feio desse bairro." Não tive como discordar, pois realmente era um lugar bonito e bem tranqüilo, uma bela vista composta pela represa, pela vegetação e pelas garças. 0 lixo jogado nas beiradas e o esgoto poderiam ser excluídos do nosso quadro.

No retorno para sua casa, passamos em frente à escola que ele estava estudando e aproveitamos para fazer uma breve tomada. E foi aí que encerramos as gravações desse dia.

\section{8 de novembro - Segunda gravação}

Começamos a nossa caminhada pelo bairro por volta das cinco e vinte da tarde, horário de verão e o dia ainda estava bem claro, mas o tempo ameaçava mudar. Fiquei com receio da chuva, o céu estava com nuvens carregadas.

Fomos caminhando pela rua de sua casa no sentido inverso ao da semana passada, do lado contrário ao de sua antiga casa. Márcio disse que queria mostrar o convento das freiras e a creche. Ao descermos pela rua onde se encontrava a creche e o convento, pude avistar, à frente, uma vasta área verde que depois descobri tratar-se de um imenso brejo por onde corria um pequeno córrego. Márcio contou que nesse córrego era despejado o esgoto da região e os moradores ainda jogavam lixo nele. $E$, pelo que pude ver, tudo isso ia desembocar na represa que estava logo ali.

Continuamos descendo pela rua da creche e do convento e, ao final, entramos por uma ruazinha estreita em que estavam algumas pessoas sentadas na frente de uma casa e, entre elas, uma garota numa cadeira de rodas. Ao vê-la, Márcio se recorda de uma palestra que havia assistido sobre acessibilidade.

A ruazinha dava acesso à rua em que morava sua irmã. No final dessa rua, pudemos avistar melhor o brejo e o bairro do outro lado. Do alto de um morrinho filmamos. Márcio começou a contar que se tratava do Jardim Laura 
e o Alvarenga, onde moravam dois colegas da escola especial. Foi possível avistar ainda a Rodovia dos Imigrantes.

De onde estávamos, avistamos, também, um campo de areia, utilizada para o jogo de futebol - dedução elementar pela a presença das traves. Márcio contou que jogava bola nesse campo com seus amigos. Quando me disse isso, pensei que ele estava se referindo ao presente, todavia, mais adiante, relatou-me que se tratava do passado. Perguntei quem eram os amigos, mas ele não se lembrava mais dos nomes.

Descemos do morrinho onde estávamos e fomos em direção ao brejo, caminhando numa trilha de barro sem ter necessariamente um destino. Estávamos apenas explorando o terreno. No caminho, avistamos um campo onde pastava um cavalo. Contou-me, então, que costumava vir nesse local buscar mato para suas galinhas; perguntei se ele não gostaria de gravar 0 local e ele respondeu que sim. Agora, sobre o mato para as galinhas... Sua mãe não confirmou essa história, dizendo alimentar as aves somente com ração. Talvez ele tenha ido uma ou outra vez, quem sabe ${ }^{8}$.

Fomos contornando o brejo até descobrirmos que havia um caminho/atalho que dava acesso ao outro lado, onde ficavam os bairros do Jardim Laura e Alvarenga, avistados e gravados do morrinho. Márcio disse que por aquele caminho dava para chegar na casa de sua ex-namorada.

Caminhamos mais um pouco e avistamos uma pinguela feita de madeira que atravessava o riozinho, ou melhor, o córrego ou o esgoto. Essa pinguela, meio improvisada, tinha uma largura de aproximadamente um metro, sem corrimão ou apoio dos lados. Confesso que fiquei com receio de atravessá-la. Márcio perguntou se eu estava com medo, mas, na verdade, também me preocupava com ele por causa de seu equilíbrio. Imaginei o que eu faria se ele se desequilibrasse e caísse no córrego. Passou pela minha cabeça, numa fração de segundos, as críticas que os profissionais da escola fariam se soubessem que eu, na condição de psicólogo, estava expondo um deficiente a uma situação de risco, de modo irresponsável. Como eu não era

\footnotetext{
${ }^{8}$ Quando estávamos observando o material gravado, Márcio se retratou dizendo que, na verdade, ele não ia buscar mato para as galinhas
} 
mais o psicólogo da escola e a vontade de atravessar era maior que o risco, deixei de lado as minhas críticas imaginárias e segui em frente; Márcio veio logo atrás. Após a travessia pensei que o melhor seria se eu tivesse vindo atrás para vê-lo e ajudá-lo, se necessário fosse, mas Márcio atravessou a pinguela tranqüilamente.

Feita a travessia, avistamos os bairros mais de perto. 0 tempo mudava e parecia que em breve teríamos chuva ou garoa e, mais uma vez, preocupava-me com Márcio que vestia somente uma camisa e estava sem agasalho. Sentia-me responsável por ele, talvez por pensar que ele não pudesse se cuidar sozinho ${ }^{9}$.

Retornamos pela pinguela, mas, dessa vez, ele foi à frente. Retornamos ao bairro por outro caminho, completando a volta pelo brejo. Avistamos a represa mais de perto. O caminho estava encharcado, com muito barro e não havia meios de contornar, pois quanto mais nos afastávamos da estrada, mais encharcado ficava o terreno. Na intenção de descobrir a melhor passagem, descobri que, na parte do caminho em que estava mais alagado e barrento, havia algumas pedras bem colocadas e supus que estavam lá propositalmente, postas, provavelmente, por alguém que passa por ali cotidianamente. Era o que eu poderia chamar de "caminho das pedras", cuja distância entre uma e outra era precisamente a largura de um passo. Fomos mais uma vez beneficiados pela iniciativa de alguma pessoa que, ao melhorar o caminho para si, melhorou o caminho para todos que por ali viessem a passar.

O relógio marcava seis e meia quando retornávamos. Já no bairro, perguntei se ele sabia onde estávamos e ele disse que na rua de sua casa.

Durante o retorno, fomos discutindo a possibilidade de conversarmos ou entrevistarmos pessoas do bairro que ele conhecia há algum tempo, para que pudessem contar um pouco da historia do bairro e também da sua infância.

\footnotetext{
${ }^{9}$ Isto mostra como nos enganamos em relação às nossas próprias convicções, quem sabe, eu acreditasse menos na sua autonomia do que eu supunha.
} 
Ao chegar a sua casa, ele convidou-me para entrar, mas receei por conta do barro em meus tênis. Sua mãe insistiu, oferecendo-me uma xícara de café que acabara de fazer. Já estava na hora deles irem para a escola, mas a mãe disse que não haveria problema se atrasassem um pouco. Como a televisão estava ligada na novela e ninguém a assistia, perguntei se ele gostaria de dar uma olhada na filmagem. Ele concordou e assistimos parte das gravações, cada um de nós com atenção em aspectos diferentes: eu observava mais as imagens, o enquadramento, a movimentação, os tremores, etc.; Márcio preocupava-se com sua voz e sua fala, mostrando-se muito crítico.

Enquanto observávamos a filmagem, sua mãe me pergunta qual era 0 meu objetivo com a pesquisa. Explico-lhe que a intenção é conhecer um pouco do bairro onde moram ex-alunos de escola especial, que eles possam mostrar e contar um pouco do bairro onde moram, o que conhecem, o que gostam, as pessoas etc. Emendando na minha explicação, sua mãe começa a contar a história do bairro - disse que antes naquele lugar onde fomos, a água avançava até a avenida, que as pessoas se sentavam à beira para pescar, isso há uns vinte anos e hoje a água recuou bastante.

Perguntei novamente se Márcio gostaria de entrevistar pessoas que conhecem a historia do bairro e a mãe responde que sua amiga era mãe de ex-aluno da escola especial e, também, uma das pessoas mais antigas do bairro.

A Sra. Floriza contou que sua amiga a ajudou bastante, inclusive no momento do falecimento de seu marido. Disse que diversas vezes se revezavam para levar e buscar os filhos até o local em que o transporte escolar os pegava para levar até a escola especial. Sugeriu, portanto, que nós a entrevistássemos.

Ao final de nossa conversa, perguntei a Márcio se ele gostaria de mostrar o filme na sua escola, pois se tratava de uma pesquisa/estudo sobre 
seu bairro e ele demonstrou interesse ${ }^{10}$. Atentei apenas para o tempo que dispúnhamos até o final do ano letivo. De toda forma, se não fosse possível neste ano, ele poderia fazê-lo no ano que vem.

\section{5 de novembro - Terceria gravação}

Como da vez anterior, por volta das cinco e meia já estávamos a postos para iniciar as gravações, mas, antes de sairmos em marcha, pergunto a Márcio o que iríamos filmar, para onde iríamos. Ele parou, colocou a mão na cabeça e ficou pensativo. Perguntei se ele não gostaria de entrevistar alguém do bairro. Ele sugere a amiga de sua mãe e, assim, nos encaminhamos para sua casa, mas lá chegando, deparamos com sua ausência. Fomos caminhando pelas ruas até chegar à rua onde mora sua irmã. Márcio recorda que as ruas por onde caminhamos não eram asfaltadas, mas, antes que ele prosseguisse, sugiro a ele que gravasse seu depoimento e, assim, passamos a fazê-lo. Além da ausência do asfalto, Márcio lembra que naquela rua só havia um comércio, um tipo de bar. Contou também que comprava pão quando sua mãe the pedia. Pergunto se ele gostaria de entrevistar o dono e ele responde que sente um pouco de vergonha, mas mesmo assim fomos. Lá chegando, Márcio pergunta ao dono que se encontrava à porta, se ele daria uma entrevista, explicando tratar-se de uma pesquisa. Sem demonstrar muita disponibilidade ele pergunta o que Márcio gostaria de saber e este responde algo sobre o tempo que estava ali no comércio. 0 homem diz que isso Márcio sabia e que não gostaria de dar nenhuma entrevista. Ficamos surpresos, não pelo fato dele se recusar a dar seu depoimento, mas pelo modo impaciente como respondeu. Márcio mostrou-se profundamente chateado com a situação, embora eu tenha tentado Ihe explicar que não são todas as pessoas que são disponíveis ou

\footnotetext{
10 Nesse momento comecei a perceber que o trabalho estava sendo realmente meu e dele - uma coautoria, talvez eu tenha entendido o sentido da negociação.
} 
gentis, mas, pelo que percebi, minha tentativa foi vã, pois seu aborrecimento com a atitude de seu vizinho perdurou por muito tempo.

Logo depois, Márcio fez uma tomada da casa em que mora atualmente. Em seu depoimento relata que se trata da casa de um conhecido que foi trabalhar no Japão e confiou a guarda da casa à sua mãe, mas que, após o falecimento de seu pai, mudaram-se para lá para que pudessem alugar a casa em que viviam e, assim, obter alguma renda para 0 sustento da família.

Após a gravação de sua casa e seu depoimento sobre ela, Márcio entrevistou uma conhecida de sua mãe, avó de uma jovem que, também, foi aluna de escola especial. Infelizmente seu depoimento não poderá ser mostrado porque, após a sua realização, a senhora mudou de idéia e não quis autorizar a utilização do material gravado.

Encerramos nosso dia conversando um pouco no portão de sua casa.

\section{3 de dezembro - Quarta gravação}

Nas duas últimas gravações tivemos a participação da Sra. Floriza. Neste dia ela nos acompanhou em nosso passeio pela represa e no último dia ela participou da conversa com a sua amiga.

O que chamo como passeio pela represa, na verdade, surgiu da idéia da Sra. Floriza em visitar sua conhecida, mãe de uma ex-aluna de escola especial que mora num bairro chamado Químicos. Como nem Márcio e nem eu nos opusemos a sua proposta, lá fomos nós, de carro, visitar sua conhecida.

A Sra. Floriza foi como uma guia de turismo, pois, por onde passávamos, ela ia dando as explicações devidas. Mostrou a primeira escola da região dizendo que muitos alunos vinham de longe, a pé, por falta de outras opções. Quando passamos pela represa, a Sra. Floriza contou que se recordava da época em que a água vinha até a beira da avenida e muitas pessoas, alguns velhos e aposentados, ficavam sentados na beira pescando. 
Disse também que havia muitas garças e que algumas delas até atacavam as pessoas.

As ruas que dão acesso ao morro em que elas moram não são asfaltadas. Fomos subindo devagar as ruas íngremes até chegarmos à casa de sua conhecida. Lá do alto do morro pudemos avistar outras regiões. Assim que chegamos, resolvi deixar o carro na parte alta, pois se descêssemos até onde ficava a casa, poderíamos ter dificuldade para retornar. Descemos cerca de cinqüenta metros a pé e, ao chegarmos, a Sra. Floriza, parecendo muito familiarizada com as pessoas de lá, foi chamando pela conhecida no portão. Ela compareceu e ficamos conversando alguns instantes ali na rua mesmo. Perguntamos se gostaria de participar da gravação, mas como não parecia se sentir muito à vontade, não insistimos. Foi então que a Sra. Floriza não deixou a escapar a oportunidade e, de uma maneira bem descontraída, começou a dar seu depoimento. Disse conhecer as jovens que ali moravam desde que elas eram crianças e estudavam na escola especial. Disse que eram muito educadas, bonitas, competentes e sofridas por viverem as dificuldades de quem vive na periferia. Aproveitou ainda a visão panorâmica proporcionada pelo local e mostrou o bairro do Alvarenga, lugar em que vive sua comadre, mãe da ex-namorada de Márcio. Ela pergunta se gostaríamos de dar um passeio por lá e então fico meio reticente, um pouco constrangido em dar uma resposta negativa. $\mathrm{Na}$ verdade, esperava que Márcio fosse mais assertivo em relação ao roteiro a ser seguido, mas ele também não parecia se incomodar com as propostas feitas pela mãe.

Saímos do bairro sem um destino certo. Quando chegamos novamente na avenida, à esquerda, retornaríamos para o bairro de Márcio e, à direita, iríamos na direção de Diadema e São Paulo. Tomamos a opção da direita.

No caminho, avistamos várias pontas da represa, mas só paramos no retorno, pois na ida fomos até bem próximo da divisa com Santo Amaro, já no município de São Paulo. 
A nossa primeira parada foi em Diadema. A propósito, a cada parada a Sra. Floriza não deixava de lembrar o quanto o nível da água havia diminuído desde a época que ela conheceu a região. Numa determinada parte da estrada, quando estávamos em Diadema, resolvemos pegar um acesso para ver se conseguíamos chegar mais perto da represa. Fomos perguntando pelo caminho e uma das pessoas disse que o acesso à represa se dava onde havia um casarão abandonado. A região era um pouco deserta, com poucas casas e muita vegetação. Fiquei meio ressabiado de atolar o carro no barro, furar o pneu, assalto, enfim, azares que se tornam mais complicados de serem solucionados em lugares isolados, mas lá fomos nós, sem deixar arrefecer o espírito aventureiro e sem deixar de nos contagiar pela disposição da mãe de Márcio. Paramos o carro num campo aberto e gramado, parecido com um campo de futebol. Seguimos poucos metros por uma picada e já pudemos avistar a represa em toda sua exuberância, compondo uma magnífica cena com o pôr-do-sol. Um pouco mais abaixo havia um grupo de pessoas que pescavam na beira com uma tarrafa. A Sra. Floriza, sempre muito disposta, cumprimentou-as e puxou uma prosa rápida. Não nos demoramos, pois em breve já escureceria e logo nos colocamos novamente em marcha para retornar. No trajeto alguns carros já acendiam seus faróis. Quando já estávamos em São Bernardo, fizemos uma última parada para apreciar a represa, mas sem sairmos do carro. Márcio fez uma tomada com o carro em movimento e esta foi a última cena do dia.

\section{4 de dezembro - Quinta e última gravação}

Esta foi a nossa última gravação. Ela foi realizada na casa da amiga da Sra. Floriza. Foram mais de sessenta minutos de conversa gravadas ininterruptamente. Contudo, infelizmente, o depoimento da amiga da Sra. Floriza também não poderá ser apresentado em virtude da ausência de sua autorização. A entrevistada comunicou a perda do papel de autorização 
muito próxima da data de finalização da pesquisa e, em todas as tentativas anteriores que fiz para encontrá-la em sua casa não obtive êxito. Desse modo, será apresentado somente a parte da entrevista com a mãe de Márcio.

Os depoimentos foram gravados com auxílio de um tripé posicionado sobre a mesa da cozinha para que o longo período de gravação não fatigasse desnecessariamente o braço de Márcio.

Elas contaram como chegaram ao bairro na condição de pioneiros, desbravadores e as primeiras impressões sobre um local sem estrutura básica para habitação, como a existência de água encanada, luz elétrica, telefone, transporte, comércio etc.

A história da vida no bairro se mistura com a vida das famílias nesse lugar: alguns acontecimentos trágicos, perdas, dificuldades, mas também exemplos de superação e a conhecida "volta por cima" possibilitada, sobretudo, pela solidariedade e cooperação entre os moradores, vizinhos e amigos.

Durante a conversa foi possível também ouvir algumas passagens sobre vida de Márcio, algumas já contadas por ele, outras propositalmente omitidas, mas depois reveladas pela sua mãe como, por exemplo, a vez em que ela colocou o dedo molhado de pimenta em sua boca, como castigo pela sua mania de sair contando as coisas. Contaram também sobre as fugas de casa e as surras de varinha, as brincadeiras de escorregar no monte de barro da olaria, a bicicleta que ele ganhou da mãe, mas logo the foi retirada, enfim, também recordações da infância.

Foi bastante presente também nessa conversa o assunto da escola especial, da necessidade de conquistar no grito as reivindicações, as dificuldades no transporte escolar, as injustiças sofridas devido a desorganização da burocracia administrativa, mas também sobre as lições de solidariedade necessária para a sobrevivência. 


\section{Segunda Parte}

Trabalho de compreensão, discussão e reflexão acerca do material produzido

Nesta segunda parte do trabalho apresento uma reflexão sobre a experiência realizada juntamente com Márcio.

\section{a. O bairro como espaço vivido}

Inicio esta parte com uma rápida descrição de seu bairro e, logo em seguida, retomo os lugares escolhidos e gravados por Márcio em seu bairro.

O Jardim das Orquídeas, como é denominado o bairro onde Marcio mora, está situado na periferia do Município de São Bernardo, mas curiosamente é relatado pelos entrevistados como se fosse um lugar "fora" dos limites da cidade, provavelmente, por duas razões: a primeira, porque há anos atrás deveria ser um hábito chamar de São Bernardo apenas o centro da cidade ou sua parte mais urbanizada, sendo as regiões mais periféricas e rurais vistas como locais fora da cidade.

O acesso ao bairro se dá pela Estrada dos Alvarengas que parte de uma praça conhecida como Área Verde, um ponto mais próximo da região central. Percorrendo essa Estrada, logo após ela passar por baixo do viaduto da Rodovia dos Imigrantes, encontra-se uma pequena rotatória que dá acesso à rua que leva ao bairro.

O Jardim das Orquídeas, assim como todo o Grande Alvarenga, 0 Jardim Laura, o bairro dos Químicos, todos citados pelos participantes da pesquisa, estão situados numa zona de mananciais e por isso estão tão próximos da represa Billings. São bairros em que a área urbana e a rural ficam muito próximas, existindo ainda regiões com muitas ruas sem asfalto.

O Jardim das Orquídeas, pelo que pude observar, é um bairro predominantemente residencial com o comércio centralizado na avenida principal e alguns outros pontos de comércio local. Dependendo da hora do 
dia, as ruas ficam praticamente desertas, com algumas poucas crianças brincando. Quando se aproxima o final da tarde e o início da noite, é notável a crescente movimentação nas ruas: são trabalhadores voltando do trabalho para suas casas, provavelmente vindos de outras regiões e muitos estudantes se dirigindo para as escolas. É um fenômeno típico do que poderia se chamar de bairros-dormitórios ${ }^{11}$.

Na rua em que se situa a casa de Márcio há apenas um único comércio. De modo geral, pelo que pude notar pelas caminhadas que fiz com Márcio, o bairro apresenta muitas residências bem construídas e com acabamento, principalmente aquelas situadas na rua de sua casa. As casas mais simples estão situadas mais próximas da área da represa.

Pelo menos na região de seu bairro que percorremos a pé, todas as vias estavam asfaltadas e com iluminação pública.

Os locais gravados por Márcio situam-se próximos a sua casa (pelo fato de termos feito o percurso a pé), com exceção de alguns pontos da represa e de outro bairro que conhecemos de carro. Os locais gravados foram os seguintes: a sua casa atual, a rua de sua casa, a casa antiga, a praça, a igreja, o bairro dos Químicos e a represa.

\section{Desvendando o lado de dentro: A Casa}

A casa em que Márcio mora fica situada numa esquina, ou melhor, na curva da rua, pois ali não é exatamente um cruzamento, mas uma bifurcação de vias. É uma casa azul que tem em sua parede um imenso grafite colorido. A construção é de dois andares: no pavimento inferior há um salão destinado ao comércio que atualmente não é utilizado; no pavimento superior fica a casa propriamente dita em que o acesso a ela se dá por uma escada externa. Tem também um quintal espaçoso onde a Sra. Floriza cria algumas galinhas.

\footnotetext{
${ }^{11}$ O dicionário Aurélio denomina como cidade-dormitório que quer dizer “cidade cujos habitantes saem, na maioria, para trabalhar em outra, retornando só para dormir”.
} 
O primeiro e único registro em vídeo de sua casa atual foi realizado somente no terceiro dia de gravação. No momento da gravação, ele faz 0 seguinte comentário: "Aqui eu moro faz dois anos, aqui nessa casa. Meu pai faleceu e nós tivemos que se virar".

Pergunto quem construiu a casa e Márcio explica que ela já estava construída e que era propriedade de um conhecido da família:

Não é bem minha. É de um cara que confiou à minha mãe cuidar da casa pra ele... enquanto ele fosse trabalhar no Japão. (...) Aí meu pai faleceu e nós tivemos que se virar ${ }^{12}$.

A Sra. Floriza fez referência à casa em dois momentos. A primeira vez fez foi no final de nosso primeiro dia de gravação, enquanto conversávamos no portão:

Aqui, nós estamos há seis anos. Nós mudamos doze dias após a morte do meu marido e dia onze agora, nesse dia onze, onze de novembro, vai fazer seis anos que ele morreu. Então tem seis anos que nós estamos nessa casa, nessa aqui, mas no bairro já tem vinte e dois anos.

Ela volta a falar da casa durante a conversa com sua amiga e explica o motivo pelo qual se mudaram para lá:

Quando ele morreu, não tinha nem o que comer em casa. Quando ele morreu eu fui obrigada a enfrentar. Eu fiz crediário e fiquei... comecei a mexer com construção. (...)

Mudei pra aquela casa que nós mora hoje, que era crua de tudo, só tinha ratos e barata (...) cano tudo estourado, tinha que mudar tudo, chovia mais dentro do que fora. E fiquei lá. Durante muito tempo eu fui dando acabamento lá e construindo aqui. E eu sempre enfiada no meio da massa,

\footnotetext{
${ }^{12}$ Esta é a segunda vez que ele repete que "tiveram que se virar" após a morte do pai. O falecimento dele foi vivido por ele e pela mãe com um momento de mudança drástica no modo de vida da família, tal como será visto em seguida.
} 
pedreiro, fazendo concreto, carregando massa. E aquela casa lá não é minha, é de um japonês. Ele era conhecido do meu marido. Ele ficou desempregado e resolveu ir pro Japão. Aí ele não tinha com quem deixar a casa e aí ele me pediu um favor por um ano. Isso uns cinco anos antes do meu marido falecer. Aí eu fiquei tomando conta da casa, que ele foi pro Japão (...). Só que ele não voltou mais, desapareceu. Aí eu fiquei cuidando da casa. Passado muito tempo, aí ele entrou em contato comigo. (...). Aí eu falei que tava morando na casa dele (...).

A mudança para essa casa é marcada por dois "acidentes" ou "imprevistos" do destino: o primeiro, a ida do conhecido ao Japão e o seu não retorno (previsto, mas não ocorrido como tal); o segundo, o falecimento do pai de Márcio.

O que os leva pra lá é a necessidade de sobrevivência, "ter que se virar" - como relatou Márcio - e a mudança é vista como uma possibilidade de obtenção de renda pelo aluguel da casa em que viviam.

Questiono, nesse momento, se, não somente a mudança para essa casa, mas própria mudança para o bairro não foi levada pela necessidade de sobrevivência. O motivo da mudança para o bairro não foi explicitado pela Sra. Floriza em seu depoimento, mas há um dado significativo a ser considerado, pois ela comenta que, antes de sua vinda para o Jardim das Orquídeas, sua família morava em um bairro mais próximo do centro e os moradores apresentavam melhor nível sócio-econômico.

De fato, o falecimento do marido acarretou muitas dificuldades financeiras para a família que somente puderam ser superadas graças ao esforço e empenho da Sra. Floriza e também pela cooperação e solidariedade dos vizinhos, sobre o qual comentarei mais adiante. Todavia, anteriormente à morte do marido, a própria mudança para o bairro já denunciava o contraste entre os hábitos e o modo de vida da família e o da comunidade local que ela, aliás, chamou de "zé povão". Tal como ela mesma havia dito, mesmo em um bairro mais pobre, com as condições apresentadas 
como a ausência de asfalto e a presença do barro, ela e sua família não abandonaram o estilo de vida e vestimenta:

Eu era viciada em salto, sou viciada até hoje. E naquele barro eu andava de salto, todo mundo admirava, como você consegue andar com esse salto fino. Naquele tempo eu era muito vaidosa, andava muito bem arrumada... Era a madame do bairro.(...) Eu tinha mania sempre de mandar fazer roupas iguais, pra mim e pras meninas, sempre de terninho, roupa social. Aí pisava naquele barro, sujava tudo, dobrava a barra da calça, mas eu ia com o salto, atolava, mas eu ia. (...) E sempre arrumada, com maquiagem, com jóia e tudo".

Penso, por isso, que a mudança para o bairro já anunciava a mudança no status social - até então não assumida -, mas que não teve como deixar de ser admitida com o falecimento de seu marido:

Aí quando meu marido já tava perto de morrer que eu perdi um pouquinho da vaidade, já tava muito doente, deu muito trabalho. Com doença e alcoolismo, aí que eu fui perdendo um pouquinho a vaidade. Aí quando ele morreu, aí larguei a vaidade de vez. Aí eu me enfiei dentro de um short, camiseta e comecei a enfrentar construção, ajudar pedreiro. Eu pagava pedreiro, mas não tinha dinheiro pra pagar servente, aí eu mesma ia ser servente. Aí eu comecei a ajudar pedreiro, pegar na massa, fazer massa, carregar massa.

Pelo que se pôde observar, para a Sra. Floriza as mudanças que sofre, provocadas pelas contingências da vida, têm implicações diretas sobre sua vaidade; isto é várias vezes repetido em seu depoimento. Todavia, a meu ver, o que é vivido como um sentimento pessoal (perda da vaidade) decorrente de uma situação familiar particular revela algo que pode ser comum a outras pessoas do bairro, ou seja, esse sentimento relatado pela mãe de Márcio pode ter sido vivenciado também por outros moradores; não digo necessariamente a perda da vaidade, mas algo relacionado a mudança 
de identidade ou no status social em função da mudança para o bairro. Em outras palavras, o que pretendo levantar como questão é o significado que a vinda para o Jardim das Orquídeas, um bairro novo, distante do centro, sem infra-estrutura, teve para os seus moradores, principalmente para aqueles que vieram como pioneiros. Certamente para muitos deve ter significado a chance de uma vida nova, a possibilidade de se adquirir uma propriedade, estabilidade, prosperidade, mas, para outros, pode ter sido vivido como uma imposição da vida, isto é, a necessidade de se mudar para um bairro mais pobre imposta pela dificuldade ou impossibilidade financeira de se manter em um bairro mais valorizado.

Esta questão me faz pensar na relação entre a história pessoal e particular de cada família com o movimento social mais amplo, isto é, relacionado ao crescimento da cidade, a valorização imobiliária em certos bairros e a conseqüente expulsão dos moradores das classes mais desfavorecidas economicamente para regiões mais distantes, além do próprio crescimento populacional na região que demanda a expansão territorial e a busca de novas áreas para a moradia. É certamente uma discussão instigante, mas como se situa para além das pretensões desta pesquisa, entendo que devo deixá-la para um outro momento. Gostaria apenas de retomar o ponto da discussão relacionado ao aspecto subjetivo, do significado ou do sentido que as pessoas dão para o ato de morar no Jardim das Orquídeas ou do modo como passaram a olhar para as próprias vidas a partir do momento em que adotaram como perspectiva o denominado bairro. Certamente não terei como saber como isso ocorre para os moradores do bairro por meio desta pesquisa, mas penso que posso trazer para conhecimento do leitor um pouco do que conheci do olhar de Márcio sobre o bairro em que mora.

Para encerrar esta parte, gostaria apenas de fazer um comentário. Como pode ser visto, ao falar sobre a casa, inevitavelmente, passa-se a falar dos significados, dos sentidos e da história da família de Márcio, tanto aquela vivida no âmbito particular como aquela relacionada ao bairro: a vinda, as 
mudanças, as dificuldades, as superações, os vínculos com os vizinhos etc. Em determinado momento, o falar sobre a casa mistura-se com o falar sobre o bairro porque casa e bairro se implicam na história de sua família. A casa, portanto, é muito mais do que uma construção, ela remete os narradores, tanto Márcio como a Sra. Floriza, sua mãe, à história vivida, às lembranças de outros tempos. A casa passa a ser testemunho dessa história.

\section{Desbravando o lado de fora: os lugares do bairro}

A seguir apresento os demais lugares do bairro gravados por Márcio, procurando, sobretudo, me aproximar do olhar do narrador e buscar compreender os significados presentes em cada um desses locais.

Esses lugares passam a ser mais ícones do bairro eleitos por Márcio, por serem marcos importantes do bairro, mas, principalmente, por fazerem parte de sua história recente ou mais remota.

\section{A rua}

A rua onde mora foi o primeiro registro feito por Márcio; saímos de sua casa e já começou a experimentar o manejo da câmera. Sobre sua rua ele diz:

Tem um lugar muito legal, a própria rua onde que eu moro. Tem pessoas super legais, gente fina. Um ajuda o outro quando pode, se pode. (Pausa) Aqui é muito sossegado. (Pausa) Tem vinte anos que eu moro aqui. É um lugar sossegado e legal pra morar. Não tem tantos assaltos, não tem tanta violência aqui. Ė uma paz, traz uma paz interior muito grande morar aqui.

O seu comentário não se restringe somente à rua, mas ao bairro como entorno, como um lugar tranqüilo, referindo-se também às pessoas, ou seja, o bairro é muito mais que um espaço geográfico, é também um lugar de 
convívio social. Márcio vê as pessoas como legais e solidárias, umas ajudando as outras. A princípio, sua fala me pareceu como algo não muito concreto, genérico, mas depois pude compreender o que ele queria dizer sobre "um ajudando o outro" no depoimento de sua mãe que comentarei mais adiante.

Márcio fala também que percebe o bairro como um lugar tranqüilo e sossegado, sem tantos assaltos ou violência; faz também uma referência a paz que sente em morar em seu bairro. Esse sentimento de paz ele retomará em outros locais como a igreja.

Como se pode ver, o bairro vivido por Márcio difere do estereótipo passado pelos meios de comunicação de massa sobre os bairros de periferia, como locais de violência, tráfico e tensão. Todavia, ele não descarta a existência da criminalidade, mas a localiza nos bairros vizinhos:

Pra lá é o Alvarenga. Lá é o lugar que tem mais... mais barra pesada. Mas tem também gente boa e trabalhadora. Não sei se é só gente barra pesada, mas tem muito trabalhador que enfrenta chuva, sol, vento, doença, vem a pé direto se não tem condição, de lá de cima, lá de cimão, até o ponto de ônibus mais próximo. Às vezes, nem tem ônibus.

Esse depoimento foi feito quando ele estava gravando os bairros do outro lado da represa, no segundo dia de gravação. Como se pode ver, ele faz menção também ao que chama de lugar "barra pesada", perigoso, violento, mas o interessante é que seu olhar não é estigmatizante, isto é, ele não faz uma generalização indevida desse bairro e é capaz de reconhecer que ali habitam também pessoas trabalhadoras que enfrentam em seu cotidiano condições adversas para sobreviver. Essa capacidade de perceber as contradições revela um olhar refinado, sensível e crítico que muitas vezes não é percebido, valorizado ou tampouco trabalhado no contexto da escola especial.

Nessa mesma gravação, logo na seqüência, ele faz uma referência também a um outro bairro: 
Você está vendo? Ali é o final do Jardim Laura. Ô tempo bom que não volta mais!

(pergunto por que) Que não tinha tanto assim... Essa fama de ser perigoso. o lugar era calmo. (Pergunto por que se tornou perigoso e ele responde). $\dot{E}$ porque os bandidos quando quer fugir, vem pra cá.

Pelo que pude entender de sua explicação, o Jardim Laura passou a ter fama de bairro perigoso porque se tornou um lugar de moradia dos bandidos. Segundo Márcio, esses bandidos não roubam no próprio bairro, vão roubar em outros lugares e voltam para lá para se refugiar. Nesse sentido, poderia se dizer, ironicamente, é claro, que se trata de um bairro tipicamente dormitório, isto é, quem mora ali trabalha ou atua em outros lugares e só retorna para dormir, tanto no caso dos trabalhadores como no caso dos bandidos. É um modo interessante de compreender 0 funcionamento do bairro, mas não há dados suficientes, além do depoimento de Márcio, para se afirmar algo com segurança sobre esse local. Portanto, passemos para outro lugar.

\section{A praça}

Para se chegar a referida praça vamos caminhando pela rua da casa de Márcio até o primeiro cruzamento e lá viramos à esquerda. Descendo essa rua até o final que, aliás, não tem saída, chegamos à praça. É nessa rua, perto da praça, que se situam a casa em que eles moravam, a casa da amiga da mãe e no alto se pode ver a igreja de Nossa Senhora do Guadalupe.

Ao término da rua se apresenta um campo gramado e, subindo, à esquerda, há uma pista de skate e, um pouco mais acima, uma quadra de futebol. Subindo pela praça encontra-se na lateral uma escadaria que dá acesso à avenida e nela está situada a entrada da igreja. 
Antes de gravar a praça Márcio fez um breve registro de sua antiga casa contando que era ali que eles moravam antes do falecimento do pai.

O registro da praça é acompanhado por um relato pouco preciso e contraditório de Márcio sobre o momento presente e de alguns flashes do passado. Pelo que contou, deu-me a impressão de que a praça é um lugar que ele freqüenta com certa assiduidade, pois diz que é o lugar onde fica a maior parte do tempo. Essa informação me pareceu contraditória porque, pelo que pude perceber, Márcio mantém poucas relações de amizade no bairro, sendo seu círculo social formado por amizades mais recentes, a partir do momento em que ingressou na oficina abrigada. Ele relatou ainda, em outros momentos, que circula pouco pelo seu bairro, andando mais pelos lugares em que moram seus amigos da oficina, devendo considerar também que sua independência é um fato relativamente recente. Desse modo, parece-me pouco provável que ele, de fato, freqüente a praça, tal como pareceu em seu relato.

A praça faz com que ele se recorde de sua infância. É um registro do passado, mas, pelo que me parece, não se atualizou.

\section{A igreja}

O fato da igreja ter sido escolhida para ser gravada indica que ela tem algum significado no mundo vivido por Márcio. Ele fala sobre a paz que sente quando está na igreja e sobre a fé em Nossa Senhora. Comenta que fez sua Primeira Comunhão e sua Crisma nessa igreja. Desse modo, pode se ver que a religião católica ocupa um lugar em sua formação e em sua história, mas não me pareceu que fosse um lugar tão significativo na atualidade. Pareceume, tal como a praça, mais um registro histórico do passado do que algo relevante na sua vida presente. A sua fé, sim, é demonstrada como algo vivo, mas não necessariamente a igreja que, pelo que pude entender, não é sequer freqüentada assiduamente. Aliás, Márcio ficou sabendo que o padre que conhecia havia sido transferido há algum tempo e já havia passado por 
ali um outro padre antes do atual. Tudo isto ficamos sabendo quando retornamos à Igreja depois de finalizadas as gravações, quando fomos informados pela amiga da mãe que ali havia sido feita uma exposição com fotos antigas do bairro.

A igreja pode ser sim um lugar em que ele se sinta confortável, em paz, um lugar que ele procura para refletir nos momentos difíceis, mas, ainda assim, fica para mim a impressão de que, na atualidade, não ocupa um lugar especial no seu universo vivido cotidianamente. Pelo que pude compreender, seu interesse e sua atenção estão voltados para onde se situam suas relações sociais mais significativas, ou seja, o círculo que envolve seus amigos da oficina abrigada.

A igreja, assim como a praça, não são locais onde ele constitui vínculos ou relações de amizade. Não são pontos de encontro, lugares preenchidos, ocupados ou atualizados socialmente. Não há alguém para ser encontrado e, desse modo, talvez existam poucos motivos para se ir a esses locais. 0 que ele busca, tal como ele mesmo disse, não se encontra em seu bairro, mas fora dele.

\section{o Convento e a creche}

O Convento e a creche não fazem parte da história pessoal e familiar de Márcio, mas dela participam de modo indireto por serem parte da história do bairro. Ao fazer a gravação do Convento ele comenta:

Esse é o convento das freiras. Onde é o convento e ao mesmo tempo é creche. Antigamente aqui não tinha creche, não tinha nada. Agora com as freiras aqui montaram. Desde que chegaram as freiras aqui mudou. Mudou pra... foi pra melhor. 


\section{A represa}

O primeiro registro da represa foi realizado no primeiro dia de gravação. A escolha do local não foi premeditada, mas ocorreu por acaso, durante a caminhada pelo bairro. A nossa ida ao local fez com que ele se lembrasse da época em que pescava com seu pai, porém sem muitos detalhes e sem muitos afetos rememorados. Hoje, parece apenas um local que guarda uma marca de seu passado que vai se tornando cada vez mais distante.

Outros registros da represa, de outros lugares, foram feitos no penúltimo dia de gravação, quando saímos de carro com sua mãe. Para ela, olhar a represa também a faz recordar do passado; não um passado de histórias pessoais, mas de um tempo em que o bairro ainda se encontrava em seus primórdios, em que as águas ainda avançavam até a beira da estrada e os velhos passavam o dia pescando. Tempos em que os moradores ainda não conheciam os benefícios do progresso e tampouco suas conseqüências, como a violência e o tráfico de drogas. Tempos em que a Sra. Floriza ainda podia desfilar com seus saltos, panos e jóias como a madame do bairro. A propósito, a situação da represa também me faz recordar do passado, do tempo da escola em que cantávamos a música:

Oi tra-la-la-la oi, oi tra-la-la-la oi,

oi tra-la-la-la-la, oi tra-la-la-la-la, oi tra-la-la-la oi

As flores já não crescem mais, até o alecrim murchou,

o lambari morreu, o sapou se mudou porque o ribeirão secou.

\section{Os bairros vizinhos}

Pelo que pude compreender da geografia do local, todos esses bairros em torno da represa Billings como o próprio Jardim das Orquídeas, o Jardim Laura, Químicos, Las Palmas e outros apresentados pelos nossos anfitriões 
compõem a região ou bairro oficialmente denominado como o Grande Alvarenga.

A Estrada dos Alvarengas, que parte da conhecida Área Verde e vai até o limite do município, contorna parte da represa que faz uma espécie de península ao contrário, quero dizer, uma ponta de água cercada de terra. Porém, esta definição merece uma correção porque hoje a parte ocupada pela água transformou-se em brejo. É este grande brejo que separa o Jardim das Orquídeas de um lado e o Jardim Laura, Químicos e o lugar chamado por Márcio como Alvarenga do outro. Por isso, quando estávamos do alto do morrinho, no lado do Jardim das Orquídeas, pudemos avistar os bairros vizinhos e, ao contornar a represa, pudemos contemplar a vista do bairro e identificar algumas de suas partes, como a rua onde mora a irmã de Márcio, o Convento etc.

No entendimento de Márcio, a represa separa também o bairro em dois lados: o lado tranqüilo, da paz - que é o lugar onde mora - e o lado "barra pesada", dos bandidos, dos trabalhadores sofridos, de colegas e da sua ex-namorada. Imaginário ou não - e aqui não vem o caso julgar - o que importa é que se trata de um modo de representar esse grande mapa e dar significados às partes que o compõem.

o que percebi como muito interessante em nossas andanças, é que tive o privilégio de compartilhar com Márcio a descoberta de uma parte desconhecida do bairro. E então, faço questão de ressaltar que agora se trata de um sentido atribuído pela minha interpretação, uma inferência de minha parte: a descoberta que no meio desse vasto brejo que se transformou essa parte da represa, que separa esses dois mundos, o lado de cá e o lado de lá, existe uma passagem, uma interligação, um atalho feito pelo caminho de barro e uma improvisada pinguela de madeira que une e aproxima os dois lados. E o que tinha que ser contornado, agora pode ser atravessado em "linha reta"; o que era obstáculo, agora é visto como caminho, o que era distante, passa a ser mais próximo. 


\section{b. O tempo vivido no bairro: um mergulho no tempo, nas histórias e nas lembranças}

Tentar separar os fios que compõem a trama, ainda que para ser didático, é correr o risco de desfazer o tecido, desfigurar os desenhos nele presentes, enfim, é perder o sentido daquilo que foi composto conjuntamente, simultaneamente. Tento, desse modo, percorrer um caminho de modo que o leitor possa ter uma noção da história do bairro e como a história da família de Márcio vai se inserindo nesse cenário.

Realizada esta tarefa, dedicarei o meu olhar à infância de Márcio, procurando ver que quadro se forma a partir das pinceladas impressionistas dadas pelos narradores e tentar imaginar como terá sido essa criança.

Passarei em seguida por um breve percurso das escolas, desde a préescola, passando pela primeira série do ensino fundamental até seu ingresso na escola especial. Este percurso será feito basicamente a partir do depoimento de sua mãe e de suas opiniões;

Por fim, um retorno ao bairro no momento presente, após a longa jornada pelos caminhos do passado. A tarefa então será compreender o modo como atualmente Márcio se relaciona com seu bairro.

\section{Era uma vez no J ardim das Orquídeas...}

\section{A história da família de Márcio}

Eles estão no bairro há vinte e dois anos e a Sra. Floriza conta sobre sua chegada ao bairro recordando as dificuldades vividas nos primeiro dias:

Eu mudei aqui no domingo. Na segunda-feira eu não sabia como fazer pra comprar uma verdura, pra ir num bar, não sabia nada, não tinha nada aqui. Aí me disseram que aqui pra baixo tinha algumas chácaras que eu fosse, comprasse as verduras, essas coisas, e que pão e leite, meu marido tinha 
que trazer lá quando vinha do serviço, carne, essas coisas, remédio... lá da Área Verde, do centro de São Bernardo, tinha lugar pra comprar. Então, eu saí com as três crianças, o Marcio num braço, a Dani no outro e a Márcia segurando na barra da minha saia. Mudei no domingo, quando foi na segunda, quando eu ia passando aqui, numa tarde de garoa meio fria, e lá eu ia caçar pelo menos uma verdura, alguma coisa, já que não tinha nem carne, alguma mistura tinha que ter.

E conta como era o bairro há décadas atrás:

Quando nós viemos? Era mato, uma casa ou outra". (...) Não tinha água (...) não tinha asfalto, não tinha luz. Luz tinha só o poste da avenida e ia levando para as casas mais próximas, mas as mais longe não tinha. Não tinha esgoto, não tinha escola, não tinha açougue, não tinha padaria, não tinha posto de saúde, não tinha nada.

Mas ela recorda que em sua casa havia luz elétrica porque no início moravam na avenida. E conta como ela era:

Na avenida também era uma casa ou outra. $A$ única coisa que tinha era a imobiliária, o bar do Miúdo, que hoje virou um salão de baile, o bar do E., que já faleceu, que é lá na entrada do Las Palmas. Os únicos, os únicos bares, botequim que era. Não tinha mais nada, não tinha açougue, se precisasse comprar pão, comprar carne, comprar remédio, essas coisas, tinha que fazer a lista. Todo dia, a hora que o marido ia pro serviço (incompreensível)... é que ele trouxesse as coisas pra casa.

Depois, relata como era a rua em que moram atualmente:

Essas casas aqui, nenhuma delas tinha. Tinha essa daqui, tinha essa casa aqui de frente, o sobrado do portão cinza. Do lado de lá tinha quatro casas, o bar aqui do lado tinha, aqui na avenida nenhuma delas tinha, só tinha 
quatro casas também na rua ao lado. Tinha só uma casa ou outra. Era mais era mato...

E o transporte era um dos maiores problemas do bairro:

Onibus era cada três hora, quatro hora que levava pra passar. A gente sentava na beira da calçada, lá na Área Verde, no centro de São Bernardo, e esquecia. A hora que o ônibus passava, tava bom.

Mas recorda também que as dificuldades eram superadas pela solidariedade entre os moradores:

Se tivesse uma emergência, aí os vizinhos, um ou outro tinha carro... Aqueles poucos que tinha carro, quando passava nos ponto, ia dando carona pro povo porque os ônibus era muito demorado.

A amizade com sua ex-vizinha e hoje amiga se deu também pela ajuda mútua entre elas e as famílias, estreitando-se principalmente em função dos filhos estudarem na mesma escola especial, pelas dificuldades que passaram juntas e pela união que precisaram ter para superar as adversidades encontradas.

A amizade entre as famílias data de um tempo muito mais remoto, sendo que os primeiros contatos feitos entre eles ocorreram logo que a família da Sra. Floriza se mudou para o bairro. Todavia, tal como lembra a mãe de Márcio, o primeiro contato não foi muito positivo em função de um fato ocorrido na família da amiga. Mas essa primeira impressão é logo superada pela aproximação entre as famílias promovida pela necessidade:

Aí meu marido logo começou a construir essa casa, essa que é alugada. Aí nós não tinha poço, não tinha água encanada, não tinha nada. Aí ele começou... aí tinha aqui, na parte de baixo, tinha uma espécie de poço que era usado pela olaria, um poço inútil, era mais pra usar para olaria. (...) Aí 
meu marido pediu pra mãe dela se podia pegar água daquele poço pra construir. Aí automaticamente nós passamos a conviver, ele usando a água daqui pra construir lá, até que fizesse poço. Aí nós passamos a conviver com eles (...). Aí convivendo é que descobri que eles eram gente boa.

E ela conta como a amizade foi se transformando e como recebeu ajuda da vizinha quando seu marido a falecer, inclusive para pegar Márcio no ponto em que era deixado pelo transporte escolar.

Após o falecimento do pai de Márcio, sua família passou por muitas dificuldades financeiras e novamente recebeu o apoio e a solidariedade dos vizinhos e amigos:

Os filho ficaram na casa da... ele e a $D$. deixei na casa da minha mãe, que a gente não tinha nem o que comer em casa quando o pai morreu. Sozinha eu me virava, eu falei, sozinha eu me viro, não vou deixar eles aqui morrendo com fome. Aí os vizinho: - mas eles vão perder o ano de escola, eles vão ficar lá, vão perder o ano? E o Márcio? Aí os vizinho pegou e fez assim, tipo união. Eles se uniram e saíram de porta em porta recolhendo, arrecadando alimento pra viúva. Arrecadaram uma boa quantidade, aí minhas cunhadas também arrecadou entre os parentes; cada um, um pouco também em dinheiro pra pagar água, luz, telefone que tava tudo atrasado (incompreensível). Aí eu consegui recuperar a situação (...).

As histórias recordadas, contadas e compartilhadas generosamente pela mãe de Mário possibilitam, desse modo, conhecer um pouco mais da realidade vivida por eles. A retomada desses percursos revela que há muito em comum nessas histórias que se mostram à primeira vista tão singulares e diferentes; são histórias marcadas pela luta pela sobrevivência, nem sempre justa ou equilibrada, por acidentes, imprevistos, perdas, fatalidades... e justamente esse reconhecimento do que é comum que possibilita a comunhão, a aproximação, o compartilhar e a construção de relações mais solidárias que, sem elas, certamente seria muito mais difícil viver. 


\section{Revisitando a infância de Márcio}

A proposta aqui não é reconstituir a biografia de Márcio, com a devida precisão cronológica, apontando quando os fatos ocorreram, apresentandoos numa seqüência temporal progressiva e linear. A idéia é trazer e compartilhar com o leitor alguns acontecimentos interessantes vividos em sua infância, pescados assim, quase que aleatoriamente da memória dos contadores. Desse modo, os acontecimentos narrados não estarão situados ou datados no tempo do relógio ou do calendário, mas no tempo das lembranças.

Um pouco desse resgate histórico entendo ter sido feito por Márcio enquanto caminhávamos pelas ruas de seu bairro e os lugares lhe traziam à tona as lembranças de vivências que tivera em tempos passados. Assim foi com a sua casa antiga em que viveu até o falecimento de seu pai, na adolescência, a praça em que brincava de bicicleta, que corria, caía e se ralava, a igreja em que fez a Primeira Comunhão e a Crisma, a represa em que pescava com o pai...

Sua mãe conta que quando eles eram pequenos não saíam muito para a rua, pois ela preferia que eles brincassem mais dentro de casa.

(...) eu nunca deixei os meus, os meus nunca saíram na rua. Uma vez ou outra, quando eles escapavam, que vinham brincar aqui na olaria, na igreja, assim que se misturavam. Mas eu nunca deixei eles assim... eles tinham quintal grande, eram em três, brincavam entre eles. Eu sempre mantive portão fechado, sempre tive cachorro bravo. Então criança de fora não entrava, os meus também não tinham costume de sair.

Desse modo, convivência com outras crianças era restrita e as brincadeiras deveriam acontecer entre os irmãos, no quintal da casa. Porém, parece que as crianças nem sempre se conformavam em ficar fechadas e davam suas escapulidas 
Contam que próximo da casa deles havia uma olaria e lá havia um barranco em que as crianças escorregavam usando papelão. E era para lá que Márcio fugia para se sujar inteirinho de barro. E a mãe recorda: "Aí procura o Marcio, mas só achava sujeira". E Márcio se lembra: "Era muito gostoso"!

Pelo que conta a mãe, as fugidinhas de Márcio aconteceram pra valer quando uma bicicleta entrou em sua vida:

Ai quando ele tava com nove anos, eu comprei uma bicicleta. Aí ele pegava essa bicicleta, bastava eu dar as costas, ele pegava essa bicicleta e sumia no mundo. Tinha que sair rua por rua caçando ele. Aí eu peguei, falei, antes que eu perca meu filho é melhor perder a bicicleta. Não deu quinze dias, desmontei a bicicleta e joguei dentro do porão. Aí eu falei pra ele, agora acabou a bicicleta, não tem obediência, eu não vou ficar caçando rua por rua que nem louca, não. Parei de pegar a vara e sair atrás. Desmontei a bicicleta. Foi mais útil. (...) Eu fiquei com pena de tirar a bicicleta, mas eu tava vendo a hora que ele ia ser atropelado por aí com a bicicleta ou alguém pra roubar a bicicleta e acabar judiando dele. Ele desaparecia com aquela bendita.

Andar de bicicleta devia Ihe dar uma imensa e prazerosa sensação de liberdade, principalmente porque ele ficava grande parte do tempo restrito a área de seu quintal e, por maior que fosse, não deveria se comparar a amplitude do espaço da rua. Assim, fugir deveria certamente valer a pena que depois sofreria pela sua infração. E sua mãe relata:

Ah, de vez em quando eu pegava a varinha, aquela vara de pé de amora. Sabe pé de amora? Você pega uma varinha e sai atrás. Eu não batia de mão, não, chinelo... Tapa, agora com a mão dói, a gente apanha junto. Então pegava a vara, mais certo. Com duas varadinha, ou então, só de mostrar a vara ele... perna pra que te... corria que era uma beleza. Ele usava aparelho nas perna, esquecia até que tinha aparelho. 
Em uma ocasião em que estávamos caminhando pelo bairro, Márcio contou também que apanhava de sua mãe:

Antigamente eu morava na rua de baixo. Eu vinha mais pra cá pra essa rua, pra brinca com os moleque. Depois, tomei cada uma. Pelo amor de deus. Apanhei muito. É que minha mãe falava que não tinha casa, fica mais na rua que em casa, então ela reclamava. Apanhava... você conhece essa vara de marmelo, que dói pra... só não vou falar porque é um palavrão, mas doía.

Pergunto a ele se realmente apanhava de sua mãe e então responde: "Pra ficar uns três dias sem pisar na rua".

A mãe conta que ele apanhava porque fugia e também porque era muito fofoqueiro. Quando a Sra. Floriza o delata como fofoqueiro e Márcio imediatamente diz "corta"! Pede para interromper a gravação, mas sua mãe continua impiedosamente:

Se eu comprasse um chinelo, o pai vinha descendo esse morro - eles ficavam na janela da sala -, quando o pai tava lá longe, ele começava: pai, a mãe comprou um chinelo, pai, a mãe foi em São Bernardo, pai, a mãe fez não sei o quê. (...) Aí eu falava, ô Marcio, não dá pra esperar seu pai chegar pra depois falar? Não, ele tinha que ficar na janela e gritar. O pai apontava, ele começava a gritar pra contar.

E ela conta como resolveu a questão:

Um dia eu falei, peraí que eu te dou um jeito. Márcio, para com isso, Márcio, para com isso. (...) E ele: tá bom, não vou falar mais. Quando era no outro dia, fazia a mesma coisa. (...) Um dia ele me pegou de chifre virado. Aí eu peguei e falei, você nunca mais vai fazer fofoca. (...) Eu deixei o vídro de pimenta na pia, aí na hora que o pai chegou: pai, a mãe foi em São Bernardo e comprou um tênis pra mim. Eu peguei o vidro de pimenta, pus o dedo dentro do vidro e falei, abre a boca. Ah? Abre a boca, abre. Aí eu peguei, pus o dedo no vidro e pus na boca dele e falei, hoje foi só uma 
prova. Outra vez que você fizer isso, você vai beber esse vidro de pimenta todinho (...) e vou travar a sua boca e você vai engolir. Nunca mais. Foi aquela provinha só, sabe. Nunca mais. (...) Cortei o mal pela raiz. Ô pimenta sagrada, foi boa demais. Foi ou não foi, Márcio?

Obviamente que a solução não deve ter agradado a ele, vide sua manifestação contrária, assim como tampouco the agradou recordar esse evento e muito menos vê-lo contado diante da câmera de vídeo.

Durante a gravação do depoimento de sua mãe, Márcio se manifestou poucas vezes e de uma maneira bastante tímida. De certa forma, poderia dizer que na presença de sua mãe ele falava bem menos do que quando estava sozinho; não sei se é porque se sentia um pouco intimidado em sua presença e, diga-se de passagem, o respeito por ela é notável, mas talvez porque a Sra. Floriza é o que eu poderia chamar de uma pessoa que domina a cena.

De fato, quando estávamos sozinhos ele era muito mais falante. Certa vez contou o episódio de um chiclete no cabelo:

Eu lembro do chiclete no meu cabelo. O moleque pegou o chiclete, a goma de mascar, e tacou no meu cabelo. Teve que a mãe do moleque tirar. Você imagina a maldade. Agora o moleque, depois que cresceu, mudou, da água pro vinho.

Márcio conta que de briga era "mais ou menos", isto é, brigava quando enchiam muito a sua paciência.

Pelo que pude entender, sua diversão nos momentos em que ficava na rua era andar de bicicleta, felicidade que, pelo visto, durou pouco. Conta que brincava de derrapar e levantar poeira, de empinar a bicicleta; não era um craque, mas também não era tão mal assim.

Além da bicicleta ele conta que jogava taco, ou melhor, tentava, porque não sabia jogar direito. 
Quando ele diz que era rueiro, talvez o dissesse não necessariamente pela freqüência e o tempo que permanecia na rua, mas pelo fato de ter aproveitado muito os momentos em que ali pode brincar. Pelo que conta, não parece que tenha sido, assim, um menino tão terrível, mas talvez ele tenha construído essa idéia de si mesmo pelas surras que levava de sua mãe.

\section{Das histórias do bairro para as histórias da escola}

Márcio fez dois anos no "prezinho" no Jardim Cláudia e depois ficou três meses na primeira série de uma escola, mas depois teve que ser transferido para a escola do bairro quando ela foi inaugurada. Nessa última passou seis meses até que a mãe resolveu tirá-lo da escola:

Ele aprendia muito bem, ele era muito inteligente depois que... Mas aqui na escola tinha muito preconceito. Aí eles não podia porque ele era problema, porque as outras crianças ficava curiosa, ficava fazendo muita pergunta $e$ que não era uma escola adequada para as condições dele. E que eu deveria tirar ele e encaminhar para uma escola especial onde ele teria um tratamento adequado. Aí vinha direto, eles me chamava e pedia pra mim tirar ele dessa escola e passasse para outra. Aí eu peguei e tirei depois de tanto falar e um dia eu peguei e não levei ele mais, nem mesmo material, pasta, nada dele eu trouxe, deixei lá.

A Sra. Floriza conta que o levou para passar por uma triagem e que depois disso foi encaminhado para uma escola especial. Na primeira escola ficou cinco anos e depois foi para uma outra em que permaneceu até ser enviado para a oficina abrigada, há cerca de dois anos atrás.

Conta a mãe que quando ele ingressou na primeira escola especial tinha mais de oito anos e já havia aprendido muitas coisas: "(..) ele tinha letra boa, fazia a letra dele era bem definida, fazia continha de primeiro ano direitinho, a lição dele era correta". 
Depois de seu ingresso na escola especial a mãe percebe que houve uma regressão em seu desenvolvimento: "Só que, quando ele entra na escola especial, ele regrediu. A partir do momento que ele entrou na escola especial, ele simplesmente travou. Ele não conseguiu desenvolver mais".

$\mathrm{Na}$ opinião da mãe, durante todos esses anos em que permaneceu na escola especial, Márcio apresentou muito pouco progresso em sua aprendizagem escolar. Ela conta que recentemente decidiu, por ele mesmo, que queria voltar a estudar. Atualmente freqüenta uma sala de alfabetização de jovens e adultos no período noturno e, segundo a mãe, está se saindo muito bem e aprendendo novamente. Para a Sra. Floriza, se a escola (ensino fundamental) não tivesse apresentado tanto preconceito em relação a seu filho, ele não precisaria ter estudado em uma escola especial.

\section{Depois da escola especial, o retorno ao bairro}

Como é a relação que Márcio mantém com o bairro onde mora? 0 que ele pensa sobre o bairro? Quais são os lugares mais significativos? Quais são as pessoas com quem se relaciona? Como foi se constituindo sua relação no período em que esteve na escola especial e o que ocorreu depois que saiu? Essas são algumas das questões que orientarão o meu percurso na tarefa de compreender um pouco essa relação.

Penso que algumas das perguntas já puderam ser respondidas anteriormente, todavia, entendo que não seja desnecessário retomá-las, ainda que brevemente.

Márcio começou a gravação dizendo o que pensava sobre o bairro. Ali, em sua primeira fala, estava sintetizado o que estaria por vir. Ele diz que é um lugar legal, sossegado e que lhe dá a sentimento de paz. As pessoas que moram ali são legais, gente fina e são disponíveis para ajudar ao outro quando podem, se podem. A princípio pensei se tratar de um discurso um pouco abstrato, mas na medida em que fui circulando com ele, conhecendo um pouco mais de sua história, a sua fala foi ganhando concretude e 
significado. Como pudemos ver, a história de sua família e a de muitas outras ali, provavelmente, foram marcadas por dificuldades que puderam ser superadas pela determinação das pessoas e também pela solidariedade entre os vizinhos. Tal como pude compreender pelo depoimento de sua mãe, não se trata de uma solidariedade construída por um movimento organizado e político dos moradores - assim como se vê em muitos bairros de periferia mas de uma solidariedade que se constitui espontaneamente diante das adversidades que a vida apresentou. Poderia dizer que é uma solidariedade natural dessas pessoas, se essa solidariedade não tivesse sido promovida pelas condições sociais e históricas que foram vivenciadas por esses migrantes da própria cidade. Ela não é ampla, no sentido de mobilizar muitos moradores, nem permanente, mas se manifesta ali, quando necessário, entre os vizinhos mais próximos. Poderia se dizer que é algo que parece pertencer mais à esfera privada, como uma extensão da família, do que vinculado à esfera pública.

Desse modo, quando ele diz que as pessoas são legais e que se ajudam, posso inferir que não se trata de uma generalização aos moradores do bairro, mas a algumas pessoas da vizinhança mais próxima. Isto não quer dizer, contudo, que ele também não considere os moradores dali "legais" de modo em geral.

Em relação ao sentimento de paz, de tranqüilidade e de sossego referidos por Márcio, estes podem ser compreendidos como decorrentes de aspectos dos quais não tive acesso, mas poderia inferir também que é pela possibilidade e liberdade dele transitar sem ser importunado ou se sentir ameaçado. Faço essa inferência a partir do que observei em nossas caminhadas, sempre muito tranqüilas e sossegadas.

Se por um lado a paz e a tranqüilidade podem decorrer de sua familiaridade com o bairro, com a segurança por ele proporcionada, pela solidariedade dos vizinhos, por outro, posso entender que é também pela preservação de uma distância necessária à manutenção de certo nível de privacidade que há muito tempo a Sra. Floriza procurava garantir, desde a 
época em que eles eram pequenos. Daí se pode entender sua preocupação em evitar que seus filhos se "misturassem" com outras crianças e, por isso, 0 portão trancado.

Apesar das fugas que deveriam ser espetaculares, pelo que se vê, Márcio não devia ser uma criança que permanecia muito tempo na rua, pois assim que era dada sua falta, sua mãe já saía à sua busca com a temida varinha.

A partir dos relatos é possível perceber que não somente na infância, mas mesmo depois, um pouco mais velho, na época da escola especial, Márcio circulava pouco pelo bairro e, desse modo, suas relações sociais acabavam ficando um tanto restritas.

Ele fala em vários momentos sobre os amigos do bairro, com quem jogava bola, mas fala deles de uma maneira vaga, pouco precisa, sem sequer recordar o nome deles ou contar algo mais específico sobre eles. Em certo momento de nossa conversa ele comenta, então, que no bairro ele tinha mais conhecidos, mas amigos não, o que é compreensível se levarmos em conta que ele pouco circulava pelo bairro. Ele conta que até teve um amigo, mas "o único virou drogado aí morreu e não gosto de lembrar". É difícil saber se era de fato um amigo ou não, pois ele mesmo diz que não gosta de lembrar. Explica, em outro momento, que fazia amigos, mas "não aqui no bairro, mas fora, como na casa da minha avó". De qualquer maneira, o que se pode perceber é que amigos no bairro mesmo, parece que não foram muitos.

Márcio faz um retrato de sua mãe como uma pessoa bastante controladora: "Era um deus nos acuda. Com quem vai, aonde vai, que hora que vai chegar, quem vai com você..."

Ele aponta esse lado controlador e superprotetor da mãe, mas reconhece os motivos pelos quais ela se comportava dessa maneira: "(..) a minha mãe tinha medo de me soltar sozinho com medo de me perder ou alguém me fazer mal, ser assaltado. Sabe aquela mãe superprotetora"? 
Todavia, essa relação com sua mãe começa a mudar quando ele consegue mostrar a ela que é capaz de ir e vir sozinho, mas, como ele mesmo disse, nem sempre foi assim:

Na rua minha mãe não deixava muito, não. Agora ta deixando porque to conhecendo um monte de amigo. Agora que eu to trabalhando ou estudando (...) a noite a minha casa fica assim, abarrotada de amigos.

O universo social de Márcio começa a se ampliar quando ele sai da escola especial e vai para a oficina abrigada, quando começa a ficar mais independente e passa a circular sozinho. Mas seu círculo de amizades não se estende no bairro, pois passa a incorporar pessoas que trabalham com ele na oficina abrigada e moram em outros lugares. Ele mesmo reconhece que tem mais amigos fora do bairro. $E$, em conseqüência disso, passa a circular também muito mais pelos outros bairros do que pelo seu:

Márcio: Eu ando mais pelo Jardim Detroit, Jardim Ipê... Vila São Pedro.

Lineu: $O$ que tem por lá?

M: Meus amigos.

L: E são amigos que você conheceu onde?

M: No meu trabalho agora.

L: No final de semana você não fica muito por aqui?

M: A não ser que eles não me convide.

L: E quando você fica por aqui?

M: Eu fico em casa. Eu sou mais da casa pro trabalho, de casa pra escola.

Pode se observar, desse modo, que mesmo Márcio ficando mais independente, a sua relação com o bairro continuou a ser restrita, assim como seu universo social.

Quando passo a observar os registros que fez de seu bairro, percebo que os locais gravados, por si só, não permitem conhecer muita coisa sobre as relações sociais que mantêm com as pessoas da comunidade onde mora. A praça, a igreja, o campo de futebol, o convento, a represa são registros do passado, mas que não se atualizaram por meio do contato social. Tal como 
indiquei anteriormente, não são locais onde ele criou raízes, vínculos e relações de amizade. Não há o que se buscar nesses locais, além de recordações do passado ou momentos de isolamento para reflexões solitárias. 0 que ele busca atualmente, não se encontra mais ali no bairro, mas fora dele.

Em uma de nossas conversas gravadas em áudio pergunto a ele se acha o bairro bonito e ele responde: "Eu acho assim. Você mora num lugar, você tem que gostar do lugar onde mora, tua casa, as pessoas em volta..." Pergunto então se ele se mudasse do bairro, do que sentiria falta. E ele diz: "da minha casa". No final dessa conversa ele diz: "É meio chato. Não é gravar essa rua. É que não tem mais ninguém nessa rua que eu conheço (...)". 


\section{Terceira Parte}

Esta terceira parte segue a mesma estrutura proposta para a discussão dos trabalhos individuais. A intenção é retomar os trabalhos feitos com Luzia, Mário e Márcio e convidá-los para dialogar entre si e, eventualmente, com algumas referências teóricas.

Proponho, então, a divisão em duas partes, apenas para fins de organização da discussão, tal como foi feito anteriormente:

a) O bairro como espaço vivido: versará sobre o que foi gravado do bairro pelos participantes mostrando, de certo modo, a representação que cada um tem do lugar em que mora; ainda nesta parte procurarei observar o que pode ser conhecido sobre as relações sociais presentes em cada bairro e de que modo os participantes se inserem nelas;

b) 0 tempo vivido no bairro: uma retomada sobre os bairros ao longo do tempo, captados pelas percepções dos participantes e seus vizinhos convidados e também sobre como as histórias individuais se cruzam na trama constituída pelos moradores.

\section{a. O bairro como espaço vivido}

Numa primeira e rápida visualização é possível notar aspectos comuns no trabalho dos três participantes, assim como aspectos particulares a cada um deles. Um primeiro aspecto que penso valer a pena observar é a discrepância em relação ao tempo e ao número de gravações realizadas. Como se pode ver, no caso de Luzia foi realizado somente uma única gravação com a duração de aproximadamente quinze minutos, ao passo que o número e o tempo de gravações nos trabalhos de Mário e Márcio foram bem maiores em relação ao de Luzia e menos desproporcional se comparado entre eles. Essa discrepância se explica pelo fato do trabalho de Luzia ter sido o primeiro (2003), podendo ser considerado como um tipo de projeto 
piloto. Em relação aos outros dois trabalhos, estes foram realizados em períodos muito próximos um do outro (segundo semestre de 2004) e após o Exame de Qualificação. Em relação à diferença no número e no tempo de gravação entre os trabalhos de Mário e Márcio, isto se deve ao fato de Márcio ter realizado uma gravação de longa duração sobre a conversa entre sua mãe e uma vizinha do bairro no último encontro. Uma outra diferença entre o trabalho de Luzia e os dois outros é que a idéia de gravar depoimentos ocorreu somente no trabalho de Mário e que, depois, foi repetido no trabalho de Márcio. Ademais, como se pode ver, há muitas semelhanças entre os trabalhos, principalmente no que se refere aos temas ou lugares gravados.

Algumas dessas semelhanças não me chamam tanta atenção como a casa em que moram, a rua da casa e as ruas próximas, visto que a gravação da própria casa pode ser considerado como algo esperado e, em relação às ruas, penso que seja somente o cumprimento da consigna dada por mim. Apesar disso, como se vê, Mário não se propôs a gravar a sua casa e tampouco posso fazer alguma inferência acerca de suas razões, posto que, durante as gravações, essa opção não havia me chamado a atenção e, por isso, não 0 indaguei sobre o fato.

Em relação à Luzia e Márcio, ambos fizeram gravações de suas casas, mas 0 aspecto mais interessante, talvez uma coincidência, refere-se ao fato dos dois terem morado em outra casa situada no mesmo bairro e muito próxima da atual. E, além disso, é claro, por terem gravado suas antigas casas e, consequentemente, se reportarem ao passado para contar uma parte das respectivas histórias.

Como foi apontado há pouco, os três realizaram gravações das ruas em que moram e também das ruas próximas. Esse aspecto se tornou mais interessante pelo fato dos três poderem se remeter ao passado, à recordação de suas infâncias no momento em que faziam as gravações nas ruas. 
Além dos pontos comuns apontados, há dois locais que me chamam a atenção, talvez por não estarem dentro das minhas expectativas, mas acredito que mais pela coincidência. Refiro-me à quadra e a igreja. Embora a discussão sobre elas já tenha sido feita individualmente, penso que pode ser interessante voltar a refletir sobre esses locais e procurar vê-los não somente pela perspectiva individual, mas tentar buscar algum nexo em comum.

\section{A quadra}

Começando pela quadra, o que a gravação feita pelos três participantes pode mostrar de comum? Ao rever os trabalhos percebo um aspecto interessante. Luzia, por exemplo, gravou a quadra num movimento giratório que fazia com a câmera para mostrar o local, ou seja, não fez uma tomada exclusiva para mostrá-la e tampouco fez algum comentário sobre ela durante a gravação. Luzia referiu-se à quadra somente em outro momento, ao contar sobre o que existia de "legal" no bairro atualmente, visto que, em seu discurso dizia que no passado o bairro era mais interessante e que restaram poucas coisas daquela época. E é neste momento, então, que cita a quadra. Todavia, como comentei anteriormente, a quadra não parece ter um significado pessoal para ela, mas ela a cita como sendo um local importante para as pessoas da favela.

A quadra para Mário comparece como algo que estava no caminho para a igreja. Fez uma gravação rápida e comentou que já havia jogado futebol nessa quadra. Seu depoimento me pareceu um pouco vago, dandome a impressão de tratar-se de um local em que casualmente aconteceu algo não muito significativo, ao contrário do que relata posteriormente em relação à igreja, tal como já foi discutido.

Para Márcio, a quadra comparece juntamente com outros espaços como a pracinha, a pista de skate e o campinho gramado que se situam todos no mesmo local. Márcio relata que é na praça que passa a maior parte de seu tempo e que era na quadra que costumava jogar bola. Pelo que foi 
visto, essas informações pareceram pouco precisas e até contraditórias, sendo inclusive corrigida posteriormente por Márcio, dizendo que o que fazia na praça era andar de bicicleta.

0 que se pode perceber em comum nos três casos é que a quadra não parece ser um local muito significativo do bairro, pelo menos na perspectiva pessoal de cada um deles, provavelmente pelo fato de não ter sido freqüentada no passado e tampouco ser ocupada no presente. Se ela não se mostra tão importante, por que então ficar discutindo sobre ela?

Penso que seja válido deter-me nessa discussão, ainda que de forma breve, porque a quadra pode ser tomada como um índice, um indicador da sociabilidade existente no bairro e, por esse motivo, usá-la como um argumento para discutir essa questão.

A quadra pode ser vista como um local onde se pratica esportes, na maioria das vezes coletivos, e também como um local de reunião, de encontro, funcionando como uma praça. E estar na praça pode significar estar junto, participar, compartilhar. Nessa perspectiva, estar ou não na praça pode indicar o nível de sociabilidade de uma pessoa em relação à sua comunidade. Porém, isso nem sempre pode ser verdadeiro e ser tomado como uma regra para todos os lugares e todas as pessoas, pois podem existir pessoas (refiro-me mais especificamente a crianças e jovens) bem relacionadas no bairro, mas que não queiram necessariamente ir à quadra por vários motivos. Todavia, o que penso ser importante é observar a diferença entre querer estar e poder estar.

Como me referi há pouco, uma pessoa pode não querer estar na praça por vários motivos, mas se quisesse poderia ter acesso a ela. E um dos "passaportes" de acesso à quadra pode ser o reconhecimento e a aceitação que determinada pessoa tem das outras que ali freqüentam ou estão. Desse modo, a quadra pode ser vista como uma ágora ${ }^{1}$ grega, destinada à ocupação pelas pessoas do povo. Todavia, a participação nos eventos, como

\footnotetext{
${ }^{1}$ Segundo o dicionário Aurélio agora é a “ praça das antigas cidades gregas, na qual se fazia o mercado e onde se reuniam, muitas vezes, as assembléias do povo”.
} 
as assembléias, era restrita àqueles que tinham o poder do voto, ou seja, os homens livres. Os demais, como as mulheres, escravos e estrangeiros ficavam de fora do exercício da democracia.

A quadra, de certa forma, funciona do mesmo modo. A princípio é para qualquer um, desde que apresente os critérios necessários para lá estar. Nesse sentido, o que conta é, certamente, a possibilidade de aceitação do grupo, aspecto que, diga-se de passagem, pode ser bastante subjetivo e arbitrário, e também a habilidade física, quando se trata de participar dos jogos. E é, nesse sentido, que a quadra se diferencia da praça, pois é um espaço de encontro, socialização, mas se diferencia da segunda quando é ocupada para a prática de esportes e, nesse momento, se torna mais seletiva. Assim, nem sempre as meninas ou os menos aptos são convidados a jogar, principalmente quando os jogos se tornam mais competitivos.

Se a quadra é um espaço de socialização, porém uma socialização seletiva que não possibilita a inserção de todos indiscriminadamente, quais são os outros espaços oferecidos pelo bairro para o encontro e a reunião dos moradores?

No caso de Luzia, poderia se dizer que é o próprio espaço da rua que é ocupado pelos seus moradores, tal como se pode ver em seu vídeo. É ali que as crianças brincam, os jovens e adultos conversam e alguns ainda tomam seu banho de sol. Mas nem todos os bairros, ainda que sejam bairros de periferia proporcionam a socialização no espaço da rua, tal como mostra o estudo feito por D' Alessio Ferrara (1999) intitulado "Olhar periférico".

Em seu estudo realizado em três bairros da região de São Miguel Paulista, a pesquisadora e seus colaboradores apontam que as ruas desses bairros não são utilizadas como espaço público pelos seus moradores, isto é, as crianças não brincam na rua e os adultos tampouco se reúnem em grupos. Em um desses bairros os pesquisadores até observam certa sociabilidade entre os vizinhos mais próximos, mas, de modo geral, o que ocorre é que muitos se entreolham desconfiados e não se comunicam. Há vários motivos que explicam o comportamento dos moradores como a 
situação precária das vias públicas, a existência do medo e alguns moradores explicam, dizendo que "o local é feio e sem atrativos". (D'Alessio Ferrara, 1999, p.64).

Se a favela de Luzia possibilita o encontro e o contato dos moradores na rua, como será que ocorre nos bairros de Mário e Márcio?

Na Vila Rosa, por exemplo, bairro em que Mário vive, não é possível observar o mesmo nível de sociabilidade encontrado na favela de Luzia. Dependendo da rua ou do lugar, é possível ver alguns meninos empinando pipa na rua ou algumas pessoas em frente de suas casas conversando. $\mathrm{Na}$ rua de Mário, por sua vez, a impressão que tive é que cada morador permanece fechado em sua casa, sem muito contato com seus vizinhos. A propósito, até mesmo as casas apresentam indícios desse isolamento, com suas fachadas herméticas, protegidas por portões que fecham até o teto. Não observei, pelo menos nas vezes em que lá estive, pessoas conversando ou reunidas na rua, provavelmente pelo fato de ser uma via um pouco mais movimentada. Além da quadra gravada por Mário, existe ainda, próxima de sua casa, uma praça com pista de skate, parquinho para as crianças e quadra de esportes, mas pelo visto, não é freqüentada por ele.

Em relação ao Jardim das Orquídeas, como foi relatado anteriormente, é possível encontrar algumas poucas crianças brincando na rua, alguns jovens reunidos em frente a uma casa ou em torno de um carro, mas na maior parte do tempo as ruas ficam mais vazias. 0 fluxo aumenta no final da tarde quando muitas pessoas retornam do trabalho e outras se dirigem à escola. Assim como foi visto nos depoimentos da mãe de Márcio durante a conversa com sua amiga e vizinha, a relação entre os moradores parece ocorrer entre os vizinhos mais próximos, não existindo, necessariamente, uma coletividade mais organizada. Em relação aos espaços de encontro, pelo que foi visto, com exceção da praça e da quadra gravadas por Márcio, não foram observados outros locais oferecidos pelo bairro como espaços públicos de socialização. 
A questão da participação na vida social do bairro, todavia, não deve ser discutida somente a partir das possibilidades oferecidas pelo local, mas como essas possibilidades são percebidas subjetivamente pelas pessoas. Ou, colocando a pergunta de outra forma, poderia se dizer: de que modo os participantes visualizam a possibilidade de relacionamento social no bairro em que moram? Ou ainda, quais são os pólos de atração social percebidos no bairro pelos participantes?

No caso de Luzia, por exemplo, mesmo a favela se mostrando como um local de grande sociabilidade, a questão é saber como ela percebe essa sociabilidade e o quanto as relações ali existentes se mostram motivadoras para o seu convívio, pois, como ela mesma se referiu, o local já se mostrou muito mais interessante em épocas passadas, mas atualmente muito de seus antigos amigos tomaram seus próprios rumos: uns se casaram, outros foram presos...

Curiosamente, a saudade do passado também aparece no discurso de Mário e Márcio com o mesmo tom melancólico presente na fala de Luzia. Eles dizem que muitas pessoas já se mudaram e que o bairro mudou bastante. Contudo, vale recordar que a circulação de Mário e Márcio em seus bairros é algo relativamente recente, assim como o contato mais independente com o bairro. Desse modo, fica um pouco difícil compreender esse sentimento em relação ao passado se, pelo menos do meu ponto de vista, é no presente que eles encontram mais chances de contato social no bairro em que moram.

Retornando às perguntas acima colocadas, diria que para Mário o comércio, as lojas ali existentes oferecem um atrativo, pois é nesses locais que ele cotidianamente busca o contato social. Todavia, como foi discutido anteriormente, se torna difícil avaliar a qualidade dessas relações. Mas, não são as lojas o principal pólo de atração social de Mário em seu bairro. É a igreja. E é sobre ela que passo a tratar. 


\section{A igreja como lugar de encontro}

A igreja comparece de maneiras diferentes para cada um dos participantes, com maior ou menor ênfase e destaque, e também com alguns significados comuns que gostaria de discutir aqui.

A começar pelas diferenças, apontaria a religião com uma delas. Se, por um lado, o catolicismo faz parte da história de Márcio, para Luzia e Mário é a igreja evangélica que se torna a principal referência.

Mas não é somente a religião que torna as experiências diferenciadas, é também o lugar no tempo ocupado por ela. 0 que quero dizer é que para alguns a igreja está mais para um registro do passado, parte de sua história do que algo significativo do presente, como é para Márcio, em minha opinião. Embora ele faça uma referência da igreja no presente, dizendo ser o local em que busca conforto e paz nos momentos difíceis de sua vida, pelo que pude notar não é um lugar tão freqüentado na atualidade, aliás, diria que faz muito tempo que ele não vai até lá, pois sequer sabia que havia mudado o padre duas vezes. Todavia, entendo que não se deva desconsiderar algumas passagens vivenciadas na igreja como, por exemplo a sua primeira comunhão. Mas, como disse anteriormente, a igreja comparece mais como um registro do passado, algo que não se atualizou em sua vida, ou ainda, se está presente é na forma de lembrança.

No caso de Luzia é possível observar também que a igreja foi um marco importante, não somente na sua história pessoal, mas acredito que também para sua comunidade. Como foi visto, a movimentação no bairro era provocada pelas atividades promovidas pela igreja: era o som ligado no meio da rua, barracas de vender roupa, bazares da pechincha, cultos ao ar livre, campanhas feitas pelas mães etc. A igreja, pelo relato de Luzia, proporcionava a ela um contato intenso com outros jovens da comunidade que acabaram se dispersando na medida em que as atividades deixaram de ocorrer e porque foram tomando seus próprios rumos, uns se casando, outros sendo presos. Contudo, para Luzia, a igreja não deixou de se fazer 
presente, não ficou apenas como uma lembrança, como no caso de Márcio, porque seu vínculo permaneceu devido a frequência aos cultos. Não sei ao certo o lugar que a igreja ocupa no presente como um espaço de socialização, mas, certamente, como ela mesma diz, não é intenso como no passado.

Em relação a Mário essa dúvida não existe porque seu envolvimento com a igreja é explícito. Diferentemente de como ocorreu com Márcio e Luzia, em que guardam um registro positivo referente às experiências com a igreja no passado, para Mário, sua experiência parece ter ocorrido de maneira diferente. As suas histórias do passado não revelam lembranças agradáveis, mas, pelo contrário, contam experiências de brigas, mal entendidos, conflitos até ter conseguido encontrar um local em que se sente acolhido. Atualmente, a igreja pode ser vista como o espaço mais importante de socialização de Mário em seu bairro. A propósito, tal como foi dito por ele, serão das pessoas da igreja que sentirá falta se, porventura, se mudar do bairro.

\section{Uma reflexão sobre a convivência social no bairro}

Gostaria agora de retomar e discutir sobre o modo como vejo a relação que os participantes mantém com seus respectivos bairros. $\mathrm{Na}$ verdade, a minha intenção é, primeiramente, fazer uma retomada e uma síntese das discussões já realizadas e, depois, partir para um outro nível de compreensão, buscando reconstituir o caminho ou processo como essas relações foram se constituindo.

Pelo que vimos, temos em questão três cenários diferentes, assim como três atores-personagens também diferentes. A pergunta a ser retomada é: como eles atuam e têm atuado em seus respectivos bairros? 0 que eles encontram como facilitadores, pólos de atração e também dificultadores para inserção na vida social no bairro? 
Em primeiro lugar penso ser importante recordar que, de certa forma, cada um dos participantes vivenciou de modo diferente a "inserção" em seus respectivos bairros, assim como mantêm relações sociais também de maneiras diferenciadas. Refiro-me à inserção entre aspas porque os três moram há muitos anos em seus bairros, ou melhor, desde que eram crianças, dessa maneira, pode-se entender que eles já estavam inseridos. 0 que pretendo dizer sobre a inserção, portanto, refere-se ao modo como cada um passou a descobrir e buscar, por conta própria, o que era oferecido pelo bairro. E, nesse sentido, temos três processos diferenciados.

Pelo que pude observar, Luzia era a pessoa que mantinha uma relação com o bairro há mais tempo, pois, já no tempo da escola especial, apresentava certa independência, indo e voltando sem acompanhamento da família e sem fazer uso do transporte escolar, diferentemente de Mário e Márcio que passaram a circular sem acompanhamento somente quando ingressaram na oficina abrigada. A propósito, vale lembrar que Luzia foi uma das participantes da Oficina de Fotografia quando era aluna da escola especial e, naquela época, já ia e voltava sozinha do local em que eram realizadas as atividades.

Em relação a Mário, ele passou a circular sozinho pelo bairro há cerca de seis ou sete anos, conforme pode recordar em conversa com sua vizinha e amiga Gisa. Sua independência começou a ser exercida no momento em que seu pai deixou de levá-lo e trazê-lo da oficina abrigada. A independência Ihe possibilitou entrar em contato com muitas pessoas do comércio local que, se já eram conhecidas, passou a ver e conversar com mais freqüência. Muitas dessas pessoas dizem que Mário é muito conhecido em seu bairro. Isso não significa necessariamente que conheçam muitas coisas a seu respeito, mas não se pode dizer que é uma pessoa anônima.

Márcio, dos três participantes, é o que ganhou sua independência há menos tempo, mas pelo visto, já faz bom uso dela e, diferentemente de Mário, sua circulação não se limita ao perímetro de seu bairro, utilizando inclusive o transporte público sem acompanhamento. Como foi visto, seu 
itinerário não se restringe à casa-trabalho-casa e já começa a circular pelos bairros dos amigos. Desse modo, pode-se dizer que Márcio não aproveitou sua independência para explorar o seu bairro, como fez Mário, mas foi investir em relacionamentos fora dele. Baseado no que foi observado e nos relatos de Márcio e de sua mãe, seu círculo de amigos é formado exclusivamente por pessoas de fora, ou melhor, pelos colegas que passou a conhecer na oficina abrigada, podendo-se dizer que, atualmente, Márcio não investe e tampouco cultiva amizades em seu bairro.

Se eu fosse perguntar a cada um deles, quem são seus amigos, certamente ouviria que, para Luzia são algumas pessoas de sua favela, talvez algumas de sua igreja, alguns da oficina abrigada com quem ainda mantém contato e as pessoas de seu trabalho. Vale lembrar que atualmente Luzia não mantém mais nenhum vínculo formal com a oficina abrigada, pois foi contratada por uma empresa que terceiriza serviços de limpeza. Desse modo, quando me refiro a pessoas de seu trabalho quero dizer que são pessoas que não são ex-alunos da escola especial, diferentemente de seus colegas da oficina abrigada com quem ainda mantém amizade. A propósito, um dado interessante e significativo é que Luzia casou-se com uma pessoa que foi seu colega na escola especial e também da oficina abrigada.

Para Mário, como ele mesmo contou, na lista de amigos ou, melhor, de melhores amigas, ele incluiria as meninas de sua igreja, a sua vizinha Gisa e talvez mais alguma pessoa do bairro. Fora dele, Mário certamente não deixaria de citar uma monitora da oficina abrigada que ele se referiu frequentemente nas gravações. Desse modo, se a oficina abrigada é um local significativo como espaço de socialização, isto ocorre muito mais em função dos profissionais que ali trabalham do que pelos colegas aprendizes, tal como são denominados os trabalhadores com deficiência.

Em relação a Márcio, como disse anteriormente, seu círculo de amigos é formado basicamente por pessoas da oficina abrigada, ou seja, ex-alunos das escolas especiais. 
E em função de que, por que ou como eles constituíram as relações sociais do modo como se apresentam?

\section{E, novamente, em busca do fio da meada}

A meu ver não existe uma única resposta ou uma relação de causa e efeito e por isso temos três casos bem distintos.

O que proponho, e novamente penso ser importante ressaltar, não é uma resposta ou uma explicação definitiva, mas um movimento de aproximação, um exercício de compreensão a respeito do processo de socialização construído e vivido por esses sujeitos fora da escola especial. E, para começar, gostaria de esclarecer que a palavra sujeito que utilizo aqui, não comparece na frase de modo fortuito, mas com a intenção clara e explícita de querer dizer e afirmar que eles se inserem e constroem relações sociais como sujeitos e não como assujeitados e, desse modo, fazendo escolhas, estabelecendo vínculos e passando a atribuir sentidos e valores a essas relações.

Para realizar esse exercício de reflexão sobre os processos de socialização, proponho iniciar buscando identificar quais foram as condições encontradas por eles que se apresentaram como barreiras e pontes dessa caminhada realizada de modo bastante singular pelos três participantes.

\section{Sobre barreiras e limites: três obstáculos a serem superados}

Em relação às barreiras ou aos limites, aponto pelos menos três fatores que não atuam isoladamente, mas que se implicam construindo uma rede complexa de relações multilaterais - isto é, não são relações de mão única ou de causa e efeito -, e, desse modo, um fator acaba interferindo no outro. São eles: a escola especial, a família e a leitura e compreensão que é feita a respeito das condições dos participantes em questão. Começarei discutindo pela ordem inversa. 


\section{a. Sobre a leitura e compreensão da deficiência como possível barreira}

Quando eu aponto a compreensão que é feita das condições dos participantes como um limitador da inserção deles em diferentes redes de sociabilidade, penso que, em primeiro lugar, devo esclarecer o que estou pensando a respeito dessa questão.

Evitando utilizar o velho chavão do bio-psico-social, tentarei explicar de outra forma. Penso que é preciso recordar que os alunos das escolas especiais referidas nesta pesquisa são crianças, jovens e adultos com deficiência mental, com maior ou menor grau de comprometimento intelectual e também, muitos deles apresentam problemas motores, de fala, de audição e visão, síndromes, quadros convulsivos e alguns problemas de saúde em geral. Muitos deles foram submetidos a cirurgias diversas e são acompanhados por médicos de diversas especialidades e também outros profissionais da saúde.

Colocado o quadro desse modo, ainda que de forma descritiva, a impressão que se dá é que se trata de alunos com muitos comprometimentos e, por que não dizer, de fato são sim, crianças e jovens com a saúde bastante fragilizada. Todavia, a questão não é querer acentuar ou atenuar os aspectos orgânicos da saúde dessas crianças e jovens, mas colocar em discussão a leitura que nós, profissionais, familiares e os próprios alunos fazemos dessas condições.

o que pretendo não é desconsiderar o aspecto da saúde ou das condições orgânicas apresentadas por esses alunos, mas refletir sobre 0 valor que é dado a elas. Refiro-me ao que a professora e pesquisadora Lígia Assumpção Amaral (1995,p.68) denominou como deficiência secundária: 
(...) deficiência secundária é aquela não inerente necessariamente à diferença em si, mas ligada à leitura social que dela é feita. Incluem-se aqui as significações afetivas, emocionais, intelectuais e sociais que o grupo atribui a dada diferença.

Assim, é importante assinalar que a deficiência secundária, ligando-se à situação de desvantagem, está impregnada dos valores sociais existentes, os quais remetem-se à própria organização institucional da sociedade.

O que ocorre com muita freqüência é uma supervalorização das condições orgânicas, de tal modo que acaba ocorrendo uma generalização, uma totalização ou seja, um movimento em que o todo (no caso a pessoa) é visto pela parte (deficiência). Certamente que o todo é afetado pela parte, mas a ela não se resume, pois entender dessa forma é deixar de lado todas as outras dimensões que constituem o ser humano. E aqui, o que está em jogo é a própria discussão a respeito do que se entende como humano e não somente uma discussão sobre a concepção de deficiência. Deixar de lado esta discussão é suprimir, no mínimo, a dimensão ética da existência humana.

Com certeza, não é uma discussão simples e não teria como dar conta dela no espaço dessa pesquisa. Limito-me, portanto, a apontar que a deficiência não deve ser tomada como valor absoluto, mas como relativo ao contexto em que ela se apresenta. Além disso, deve-se levar também em consideração a dimensão da singularidade, ou seja, o modo como cada pessoa se apropria das condições que the são dadas e a partir delas descobre e aprimora recursos para se desenvolver e viver. E esta é a parte mais fantástica da história que, infelizmente, muitos de nós que convivemos cotidianamente com pessoas com deficiência deixamos de ver por estarmos presos somente à percepção das dificuldades e dos limites. Sobre isso há um trabalho de pesquisa que não poderia deixar de ser citado que se intitula “(D)eficiência e trabalho, analisando suas representações, realizado por Blanche Warzée Giordano (2000). Em sua pesquisa sobre as representações de técnicos, encarregados, empregadores e portadores de deficiência mental 
a respeito do trabalho e trabalhador com deficiência mental, a autora aponta a "ênfase nas limitações (intelectuais, pessoais, sociais e afetivas) em detrimento de suas potencialidades" (2000, p.146) dada por encarregados/empregadores e técnicos à representação de deficiência mental e, consequentemente, ao modo como percebem os trabalhadores com deficiência.

A partir dessa discussão, é importante considerar, portanto, que a deficiência e as condições de saúde apresentadas devem ser vistas como limitações reais e concretas que não devem se desprezadas, mas não se pode esquecer da leitura social que é feita das condições apresentadas e que estas sim, podem ser definitivamente limitadoras.

\section{A família e a escola como elementos complementares}

Em relação aos outros dois fatores, penso que, de certa forma, estão intimamente ligados ao primeiro, isto é, a compreensão que é feita da deficiência. Família e escola mantém uma relação de complementaridade e oposição no tocante à formação de crianças e jovens com deficiência; às vezes de cooperação e colaboração, noutras de disputa, competição e rivalidade. Infelizmente é muito comum encontrar uma relação de acusação e culpabilização mútuas pelo desenvolvimento que não é percebido pela família ou pelos profissionais, embate esse levado pela dificuldade das partes em se implicar na responsabilidade que thes cabe na educação dos filhos e alunos e, também, como meio de se defenderem dos sentimentos de culpa e incompetência.

Embora cada uma das instâncias (família e escola) tenha papel específico na educação, tenho percebido como profissional que o modo como agem em relação à criança e o jovem é, de certa forma, muito semelhante. Nesse sentido, penso que, ao realizar uma discussão a respeito da família e 
da escola separadamente, não alcançaria o ponto que eu penso ser importante chegar que é justamente a relação entre família e a escola. Todavia, farei apenas uma breve passagem por elas para depois retornar a discussão.

\section{b. A família como barreira}

Há vários estudos a respeito da relação entre a família e a pessoa com deficiência e debruçar-me sobre eles implicaria em caminhar por uma trilha que me desviaria de meu objetivo nesse momento, tal como me referi há pouco. Desse modo, gostaria apenas de citar o trabalho de Omote (1998, p.125) intitulado "Famílias de deficientes: estudos relatados em dissertações e teses" que apresenta um panorama de como o tema tem sido tratado nas pesquisas acadêmicas.

Omote aponta em seu artigo que a partir da década de 80 vem crescendo 0 interesse de pesquisadores a respeito da relação entre 0 deficiente e sua família. Para sua pesquisa foi consultado um total de 48 documentos entre dissertações (41) e teses (07), sendo que desse total 30 se referiam à deficiência mental e o restante às demais deficiências. 0 autor aponta a existência de alguns temas preferenciais nas pesquisas levantadas, observando que do total 18 dissertações e teses tratavam de questões relativas a "conseqüências da deficiência sobre os membros familiares e a dinâmica de funcionamento familiar" (Omote, 1998, p.128). Um outro aspecto interessante apontado por Omote refere-se a semelhança nos efeitos causados na dinâmica familiar por diferentes condições incapacitadoras ou deficiências, citando a dissertação de Terrassi (1993) intitulada "Família do deficiente: aspectos comuns e específicos relatados pelas mães de crianças portadoras de diferentes deficiências" que trata exatamente dessa questão.

Ainda sobre os efeitos da presença da deficiência na família, em seu livro "Conhecendo a deficiência - em companhia de Hércules", Lígia Amaral 
(1995) realiza uma discussão a respeito desse impacto apontando um aspecto fundamental para compreensão dessa dinâmica que é a presença da ambivalência, isto é, a vivência de sentimentos intensos que oscilam entre polaridades: "amor e ódio, alegria e sofrimento; uma vez que as reações concomitantes oscilam entre aceitação e rejeição, euforia e depressão (...)" (1995, p.74).

No artigo intitulado "Alunos de classes especiais e sua família: algumas reflexões" Yaegashi et al. (2001) realizam uma discussão a respeito da dinâmica de famílias com filhos deficientes e fazem uma citação do artigo de Glat bastante oportuna. A autora citada observa a influência da família no processo de integração social do deficiente e atenta que esta pode desempenhar um papel tanto de facilitação como também de impedimento.

A partir dos trabalhos citados, o que se pode ver é que a dinâmica familiar diante da deficiência é repleta de sentimentos contraditórios, muitos deles não conscientes, que tanto podem ajudar como dificultar o crescimento do filho deficiente. Trata-se, portanto, de relações complexas que não devem sofrer julgamentos morais precipitados por parte daqueles que sentem isentos das implicações vivenciadas pelas famílias. E é nesse ponto que entra a escola que, tanto quanto a família, pode desempenhar um papel de facilitação como de bloqueio em relação ao crescimento do aluno deficiente e de sua família. Todavia, antes de me aprofundar nessa discussão, gostaria apenas de apontar muito rapidamente, algumas questões específicas relacionadas à ação da escola especial no desenvolvimento de seus alunos.

\section{c. A escola especial como barreira}

É sabido que as críticas à escola especial não são recentes, mas ganharam maior ênfase e visibilidade com o movimento mundial em defesa da escola inclusiva, que tem levado à realização de eventos internacionais que, por sua vez, orientam as políticas públicas educacionais de vários países, inclusive do Brasil. 
As discussões têm sido polêmicas, acaloradas e com posições muitas vezes divergentes; alguns defendendo o fechamento das escolas especiais e a inclusão total e irrestrita de todos os alunos na rede regular de ensino, outros refletindo sobre uma inclusão mais seletiva. Alguns desses posicionamentos puderam ser vistos no "I Ciclo de debates multiprofissionais sobre a inclusão da pessoa portadora de deficiência", realizado pelo Programa de Pós-graduação em Distúrbios do Desenvolvimento da Universidade Presbiteriana Mackenzie no ano de 1998 e posteriormente tendo as comunicações dos palestrantes publicadas na revista "Temas sobre Desenvolvimento" (1998).

Como me referi há pouco, embora as críticas à escola especial tenham crescido com o movimento da escola inclusiva, elas são muito mais antigas do que se pode imaginar. Vygostsky (1997) em seu livro "Fundamentos de defectologia" já fazia críticas à escola especial por afirmar que ela era antisocial e educava para a anti-sociabilidade (1997, p.84). Outra crítica feita por ele referia-se ao fato das escolas especiais privilegiarem uma "cultura sensorial", isto é, um ensino voltado para as funções elementares e não para as funções psicológicas superiores, tal como ele defendia (Góes, 2002, p.101). Nessa perspectiva, revela-se ainda a predominância do aspecto orgânico na concepção de deficiência e também uma ênfase no déficit, deixando de considerar o aspecto social do desenvolvimento, assim como as potencialidades da criança. Em vista das críticas que fazia à escola especial:

“(...) Vygotsky defendia uma escola que se abstivesse de isolar essas crianças e, em vez disso, integrasse-as tanto quanto possível na sociedade. As crianças deveriam receber a oportunidade de viver junto com pessoas normais (Van der Veer, R. e Valsiner, J., 2001, p.75).

Embora Vygotsky reivindicasse que os muros das escolas especiais fossem derrubados para que os alunos delas não fossem mais privados do contato social que necessitavam para o desenvolvimento, por outro lado 
defendia a existência de uma "educação especial" que pudesse atender as especificidades apresentadas por alguns alunos quando eles estivessem inseridos na escola comum (Góes, 2002, p.110). Desse modo, não se tratava de escolher entre uma ou outra, mas oferecer as oportunidades de socialização, desenvolvimento e aprendizagem proporcionadas pela escola comum e os recursos necessários para atender as especificidades de determinados alunos.

Se por um lado a escola especial vem sendo criticada pelo fato privar seus alunos do convívio com as demais crianças, por outro, a escola comum não escapa das críticas na medida em que reproduz em seu interior os mecanismos de exclusão das diferenças. Essa questão foi apontada e discutida durante um debate promovido pelo Conselho Regional de Psicologia a respeito da educação especial, mais especificamente por Crochík (1997a) Amaral e Bueno (1997).

Olhando por esse prisma, a escola especial e a escola comum não são necessariamente antagônicas, mas complementares, ambas funcionando a partir da mesma lógica da seleção, classificação e homogeneização. Nesse sentido, mesmo que as escolas especiais fechem suas portas e seus muros sejam derrubados, isso não significará necessariamente a inclusão dos alunos com deficiência mental, pois, se não houver uma transformação na lógica que opera a escola regular, ou melhor, no sistema educacional, o que passará a ocorrer será o que Lígia Amaral (2002,p.240) denomina como "inclusão marginal" ou uma segregação mascarada.

Retomando a questão anteriormente debatida, a partir do que foi exposto, o que se nota é que a escola especial também é responsável pela restrição social imposta aos seus alunos, devendo, portanto, refletir e compartilhar com a família a responsabilidade pelo ônus causado por essa restrição. 


\section{Retornando à difícil relação entre a família e a escola}

Na escola especial e nas demais também (Patto, 1997, pp.281-296) temos o péssimo hábito de frequentemente fazer julgamentos morais das famílias e principalmente das mães - visto que na maioria das vezes são elas que acompanham com regularidade a vida escolar dos filho. Quando algo se situa fora de nossas expectativas e deixa de funcionar conforme 0 "planejamento escolar", passamos a procurar pelos responsáveis. Geralmente estes são encontrados fora da escola e culpabilizados sem qualquer reflexão ou autocrítica por parte dos profissionais.

$\mathrm{Na}$ escola especial este processo de culpabilização pode ser muito mais acentuado porque, de modo consciente ou não, os profissionais tendem a tomar partido dos alunos deficientes, como se fossem eles os salvadores das indefesas crianças (independentemente da idade cronológica delas) que são maltratadas por suas famílias impiedosas ou que, pelo fato de serem "desestruturadas", não apresentam condições de educar os filhos adequadamente. Revela-se, dessa maneira, um modo bastante maniqueísta e simplista de compreender a dinâmica familiar, como se esta fosse constituída por dois lados antagônicos e não complementares ou seja, a família como vilã e o filho deficiente como vítima. E olhar por esta perspectiva, é desacreditar, tanto quanto a família que é criticada pela escola, nas possibilidades de crescimento dos alunos com deficiência e, por que não, também na possibilidade de crescimento da família.

Quando discutimos a questão da independência dos alunos de escola especial é muito comum encontrarmos a explicação reducionista e simplista de que os alunos permanecem na sua condição de menoridade, independente de sua idade cronológica, em função da superproteção exercida pelos pais porque estes não desejam que os filhos cresçam ou porque sentem culpa, vergonha etc.

Penso que, se a superproteção é manifestada pelos pais, é porque existem razões subjetivas e objetivas para que isso ocorra, afinal, ninguém 
se torna superprotetor simplesmente porque deseja ser assim ou porque sente prazer em impedir o crescimento do filho. Desse modo, ela pode ser compreendida de uma outra forma, não apenas em seu aspecto negativo, como uma manifestação desmedida, exagerada, nociva e perversa ou apenas como a expressão da rejeição que se pretende ocultar, mas também como intenção de cuidado, de desejo latente de crescimento que ainda não descobriu o melhor caminho para se tornar manifesto, pois, afinal, não podemos esquecer das contradições inerentes ao ser humano e, desse modo, se acreditamos que existe uma tendência paralisante em função da dificuldade de superação dos medos, angústias, não podemos nos esquecer que existem também as forças transformadoras que colocam a vida de novo em movimento.

Se entendemos que a criança ou o jovem precisam de sua família para poder crescer, precisamos entender, portanto, que a família precisa ser compreendida, fortalecida e se sentir confiante e competente para cuidar e educar seus filhos, mas sabemos que esta não é uma tarefa fácil, pois muitas delas entram em processo de desgaste e descrença em relação ao filho e sequer podem compartilhar esse sentimento pelo receio de serem criticadas.

O desenvolvimento da confiança recíproca entre família e jovem é algo a ser aprendido e estimulado, afinal ninguém nasce sabendo como ser um bom pai ou uma boa mãe. 0 exercício de ser pai e mãe ocorre por ensaio e erro porque não existem receitas prontas e infalíveis. Nesse sentido, a ação da família deve ser entendida não apenas como um erro ou uma ação mal intencionada, mas como a expressão do melhor que a família sabe ou pode dar naquele momento.

\section{Resgatando a responsabilidade da escola especial}

Omote (1998, p.125) aponta que atualmente existe o reconhecimento por parte dos profissionais da educação especial da necessidade de se atender não somente 0 aluno, mas também a família, por entender que 
ambos supostamente sofrem as conseqüências da deficiência. Desse modo, não somente a criança ou o jovem são considerados usuários dos serviços especiais, mas também suas famílias. Ferreira (1999, p.41) em seu artigo "Espaço pessoal: uma necessidade dos pais de portadores de deficiência mental" discute exatamente essa necessidade apontada por Omote. A autora comenta que é comum observar "pais emocionalmente mobilizados e racionalmente imobilizados diante do conhecimento da deficiência mental de um descendente direto". Ferreira comenta que apesar da fragilidade vivenciada, os pais têm que assumir o filho e, como esta não é uma tarefa fácil, torna-se necessária uma ajuda externa. Omote observa que muitos desses atendimentos são feitos de maneira precária por vários motivos, apontando a falta de formação adequada dos profissionais como um deles. Mas, afinal, qual é o problema da formação dos profissionais?

Lígia Amaral (2001) em seu artigo "Formação profissional e concepção de deficiência: onde o ponto de encontro"? propõe uma discussão a respeito da formação/educação dos profissionais e aponta que usualmente as propostas de formação enfatizam muito mais o conhecer do que o pensar. Em minha experiência profissional tenho, infelizmente, constatado o que a autora comenta, pois, o que venho encontrando como propostas de formação são palestras de profissionais renomados para platéias numerosas, cursos e mais cursos sobre aspectos pontuais visando o atendimento imediato de demandas sem exigir uma discussão ou reflexão mais aprofundada. Tal como venho dizendo, as respostas chegam antes que as perguntas possam ser formuladas. Esse tipo de formação tão comum não deveria ser denominado como tal e sim como proposta de informação, pois é este 0 aspecto que é privilegiado.

O grande problema é que, ao privilegiar a informação, não se proporciona a formação integral do profissional, isto um processo de reflexão que leve em consideração aspectos da sua subjetividade. E este é um ponto fundamental quando se lida com a questão da deficiência. 
Lígia Amaral, em diversos momentos nas aulas, palestras e também em seus trabalhos publicados (Amaral, 1994, 1995) vem insistentemente apontando para importância da reflexão acerca dos fenômenos psíquicos que são mobilizados quando uma pessoa se vê diante da presença da deficiência. Em seu artigo (Amaral, 1999,p.18) intitulado "Alguns apontamentos para reflexão/discussão sobre: diferença/deficiência/necessidades educacionais especiais" a autora propõe uma reflexão sobre a questão referida no título enfocando principalmente a dimensão ideológica e nos presenteia com uma síntese sobre os aspectos afetivo-emocionais provocados pela presença da deficiência de uma forma bastante clara que gostaria de reproduzir aqui:

- "afetividade não diz respeito apenas a amor, alegria amizade etc., diz também respeito a medo, ódio, repulsa, tristeza...;

- não somos incentivados a expressar e muitas vezes sequer a pensar e admitir sua presença em nós mesmos - quando muito nos outros;

- a diferença significativa pressupõe uma alta probabilidade de que sua existência provoque a emergência hegemônica de emoções, emergência essa marcada prioritária - e inicialmente - pelo medo, pela raiva, pela repulsa...;

- qualquer uma dessas emoções gera imediatamente uma postura de defesa;

- essa defesa poderá levar a reações de ataque ou fuga".

0 encontro com a deficiência mobiliza sentimentos e emoções que muitas vezes recusamos a tomar contato porque nos fragiliza. E justamente essa recusa que se manifesta de diversas formas como mecanismos psicológicos de defesa, termo que Lígia Amaral toma da psicanálise, é que impossibilita a descoberta de que a ameaça não está no outro, mas em nós mesmos. Esse processo pelo qual se forma o preconceito, amplamente discutido por Crochík (1997b), se perpetua e se propaga na medida em que 
os profissionais estão impedidos, por questões pessoais, emocionais, institucionais, enfim, de refletir sobre as atitudes que apresentam diante dos alunos deficientes e suas famílias.

Certamente esta não é uma tarefa fácil e que depende somente da vontade individual de cada profissional, pois, tal como mostrou D'Antino (2001) em seu livro "A máscara e o rosto da instituição especializada: marcas que o passado abriga e o presente esconde", há toda uma dinâmica institucional que deve ser considerada e refletida para que ofereça mínimas condições para reflexão e formação.

De toda forma, penso que, sem essa reflexão a respeito da própria subjetividade, dificilmente os profissionais conseguirão transformar o modo como percebem os alunos e familiares, assim como tornar mais satisfatória a relação com eles.

É preciso operar uma mudança no modo como os profissionais percebem a dinâmica familiar ou, até mesmo, a concepção que têm sobre a família. É preciso superar a visão da família como uma instituição naturalmente estruturada ou desestruturada e considerar que as relações que se dão em seu interior são afetadas pelas circunstâncias históricas, sociais e sobretudo psicológicas quando envolve a presença da deficiência; é preciso superar a visão maniqueísta e de causa-efeito, modificar o modo de percebê-la como sendo composta por partes ou unidades independentes que não se afetam mutuamente ou que somente uma das parte é responsável por afetar a mais frágil, deixando de considerar a reciprocidade das relações. O grande desafio é, portanto, uma reflexão radical que consiga superar a forte tendência de culpabilização da família e vitimização do deficiente. Quem sabe assim, teremos mais chances de nos libertar das amarras que impomos a nós mesmos e que impedem também aqueles que conosco convivem de se libertarem e se emanciparem. Como disse Paulo Freire, a libertação é uma tarefa coletiva, pois "ninguém liberta ninguém e ninguém se liberta sozinho". Desse modo, não há como esperar que os alunos com 
deficiência mental façam a tarefa de casa sozinhos ou que alguém possa fazer isso por eles.

\section{Desmanchando muros e construindo pontes para a inclusão social}

Esta é a grande tarefa a ser realizada. Se, por um lado, apontei como barreiras à socialização e à emancipação dos jovens com deficiência mental a leitura social da deficiência, a atitude da família e da escola, por outro lado, são exatamente esses três fatores que possibilitarão o êxito na participação social. Como foi discutido anteriormente, a leitura que se faz da deficiência é algo relativo e pode ser modificado, podendo ser vista não somente como uma condição de impedimento, mas também como uma condição diferenciada. E um outro aspecto importante que foi apontado é que tanto a família como a escola podem funcionar como barreiras de crescimento, mas também como facilitadoras do processo de inclusão social e emancipação.

Para que essa discussão não se limite às minhas conjecturas teóricas, proponho um retorno às experiências concretas para observar qual foi o caminho percorrido pelos participantes e quais foram as pontes que utilizaram para ir ao encontro da convivência social mais ampla.

Antes de iniciar esse percurso, gostaria de recordar brevemente quais foram os locais ou grupos que os participantes encontraram a chance de partilhar as suas vivências quando se encontraram fora da escola especial. No caso de Luzia poderia certamente apontar o seu bairro e supostamente a comunidade de sua igreja; no caso de Mário, o local que ele encontrou maior acolhimento foi a igreja; já no caso de Márcio, diria que ele ainda não encontrou um caminho certo para explorar as oportunidades oferecidas pelo seu bairro porque sua estréia foi relativamente recente, desse modo, suas relações sociais continuam predominantemente formadas pelas pessoas da oficina abrigada. Há que se considerar que no caso de Luzia e Mário esse 
vínculo com a escola especial, por intermédio da oficina abrigada que considero como uma extensão da escola especial, ainda permanece forte, tanto para um, como para outro. Desse modo, poderia se dizer que mesmo de fora dos muros da escola especial, ela ainda se faz presente na vida social de seus ex-alunos. Contudo, embora essa presença seja maior ou mais significativa para um ou outro, o que é mais interessante é que esses sujeitos encontraram caminhos para buscar novas relações sociais. E o que proporcionou a descoberta dessas novas relações?

Tenho comigo uma hipótese que gostaria de compartilhar aqui e gostaria de recorrer a dois exemplos ou duas ilustrações para poder me explicar. Um deles é uma fiç̧ão e outro, um exemplo real. Começarei pela ficção: trata-se do filme "O meu pé esquerdo".

Lembro-me de uma cena ${ }^{2}$ do filme em que o protagonista - um rapaz com sérios problemas motores devido à paralisia cerebral - participa de um jogo de futebol com os garotos de seu bairro. Devido as suas dificuldades motoras, ele é posto no gol, mas é chamado para cobrar um pênalti em determinado momento da partida. 0 goleiro o desdenha por causa de sua deficiência, mas Christy, como é chamado o personagem, acaba marcando o gol.

No caso desse personagem, ainda que seja numa situação fictícia, o que the possibilita participar com os outros garotos do jogo de futebol? 0 que the possibilita sua entrada na quadra é o conhecimento e a aceitação das demais pessoas que estão no jogo, no caso do filme, estas pessoas são representadas pelos seus irmãos. São eles que fazem a "ponte" para que 0 irmão possa se relacionar com os outros garotos do bairro.

0 outro caso não é uma ficção, mas o depoimento de uma pessoa com deficiência. Trata-se de um pequeno trecho da história de vida contada por Lígia Assumpção Amaral que se encontra em sua dissertação de

\footnotetext{
${ }^{2}$ Esta cena foi também selecionada pela professora Maria Eloísa D’Antino (2001)e faz parte do material composto por filmes de campanhas publicitárias de instituições especiais que a autora analisou em sua tese de doutorado intitulada "Deficiência e a mensagem reveladora da instituição especializada: dimensões imagética e textual”.
} 
mestrado intitulada "Resgatando o passado: deficiência como figura e vida como fundo", que foi recontada em artigo escrito pela própria autora (Amaral, 1998b) intitulado "Sobre crocodilos e avestruzes: falando de diferenças físicas, preconceitos e sua superação".

No pequeno trecho chamado "Café-com-leite", a autora narra uma passagem de sua infância, na verdade duas, uma distinta da outra.

Em um dos relatos ela conta sobre as brincadeiras que participava na sua rua nas noites quentes de verão. Ela fala da ambivalência que sentia por querer estar lá fora, mas ao mesmo tempo não querer abrir mão da proteção que sentia em sua casa, das brincadeiras que podia participar e das outras em que participava como "café-com -leite":

Nestas eu era café-com-leite, e era sempre terrivel ser café-com-leite. No jogo de equipe, a humilhação de me sentir a escolhida por favor (a custo as lágrimas eram engolidas por trás do sorriso amarelo). No "salve-se quem puder", a de roçar no pegador e não ser pega, de não receber 0 lenço, de não ser atingida pela bola. (Amaral, 1998b, p.28)

Lígia Amaral recorda também de outra experiência, esta ocorrida na escola. Conta que era dispensada das aulas de educação física e ficava sentada, "observando o mundo acontecer" até que certo dia a professora a chamou para junto da roda de alunos e lhe propôs participar das aulas, realizando as atividades que pudesse fazer. E no final ela comenta: "Eu nunca precisei ser café-com-leite nas aulas de ginástica e, ainda por cima, ganhei o calção azul bufante e a camiseta de malha"! (1998b, p.29)

Retorno, então, a mesma pergunta que fiz anteriormente: o que torna possível a sua participação nas aulas de ginástica? Penso que a resposta é a mesma que foi dada à situação do filme. Se no caso do personagem Christy quem Ihe possibilita a entrada e a participação no jogo são seus irmãos, no caso de Lígia foi a sua professora de educação física. Ou seja, foram essas

\footnotetext{
${ }^{3}$ Existe um livro da autora com o mesmo título que foi publicado em 2004 pela editora Casa do Psicólogo.
} 
pessoas que fizeram o papel de ponte e que aproximaram as distâncias que pareciam até então intransponíveis. Curiosamente, ambas experiências estão relacionadas a atividades físicas e esportivas que a maioria das pessoas consideraria inapropriadas à participação de pessoas com deficiência física. São dois exemplos, dois casos de pessoas com deficiência que conseguiram o passaporte para entrarem no seletivo espaço da quadra. E no caso de nossos participantes, quem desempenhou o papel de "ponte"?

No caso de Luzia, pelo que se pode ver, as próprias condições do bairro pareciam favoráveis à sua inserção, mas penso que a mediação das pessoas da sua família pode ter facilitado também o seu relacionamento. Um outro aspecto que pode ter favorecido o contato e a aproximação com os jovens de seu bairro foi a participação nas atividades da igreja. E esta, por sua vez, deve ter ocorrido por intermédio de sua mãe que também freqüentava a mesma igreja naquela época. Atualmente Luzia não necessita mais dessas mediações em seu bairro porque pode ter acesso direto às pessoas. Poderia se dizer que nesse espaço Luzia conquistou sua autonomia no que se refere ao contato com as pessoas.

No caso de Mário, não tenho dúvidas que a pessoa responsável por abrir as portas da igreja foi sua mãe. Foi ela que, pelo seu interesse pessoal, começou a chamar a atenção de Mário para a religiosidade e o introduziu na busca pela fé. Não deve ter sido ela que o levou à igreja que freqüenta atualmente, mas certamente foi ela quem tornou possível o desenvolvimento de sua autonomia, a iniciativa para a busca, para o encontro de outras pessoas. E hoje, Mário exercita sua autonomia para ir à igreja e também para buscar outras relações em seu bairro.

Dos três, poderia dizer que Márcio é o que ainda está dando os primeiros passos de sua independência. Mas quem 0 iniciou, quem the possibilitou a caminhada em direção à sua independência? Foi sua colega e vizinha, também ex-aluna de escola especial que ofereceu companhia para que Márcio não fosse sozinho até o local de seu estágio e lhe possibilitou a confiança necessária para saber que não precisaria mais de sua ajuda. E, a 
partir do momento que Márcio pode demonstrar isso também à sua mãe, esta passou a entender que, de fato, ele estava pronto para caminhar por conta própria. E foi desse modo que ele conquistou a sua confiança e, a partir desse momento, ela entendeu que a "superproteção" já não era mais necessária.

O que eu vi de mais interessante nessa história é que Márcio tem um vizinho que também é aluno de escola especial e que em breve iniciará na oficina abrigada. Ao saber disso, ele se propôs, por iniciativa própria, a ser 0 acompanhante de seu colega, assim como sua colega um dia foi para ele.

Esses três casos e tantos outros mostram um caminho possível de ser percorrido. Mostram que pessoas com deficiência podem se tornar autônomas, ter iniciativa em suas buscas, ter escolhas e tomar decisões apesar das condições que apresentam. São três exemplos de caminhadas distintas, cada um caminhando de acordo com suas possibilidades.

Esses três casos mostram também que as famílias nem sempre desempenham apenas o papel de barreiras impedidoras, podendo também exercer o papel fundamental de ponte para lançá-los à vida. 


\section{b. Uma reflexão sobre o tempo vivido}

A reflexão acerca do tempo vivido foi organizada a partir de dois pontos: o primeiro, referente às histórias dos bairros e, o segundo, sobre as histórias dos participantes no bairro. Todavia, essa divisão ficou mais explícita na discussão sobre os trabalhos realizados com Mário e Márcio. No caso de Luzia, não realizei uma discussão a respeito da história de sua favela, tal como nos trabalhos posteriores, simplesmente porque o material gravado por ela não abordou ou privilegiou esse aspecto. Tive acesso a algumas informações sobre a história do bairro durante as nossas conversas, mas considerei que não eram suficientes para uma sistematização. Desse modo, na discussão sobre o seu trabalho realizei uma reflexão acerca de suas lembranças pessoais no bairro e o modo como elas se relacionavam com o tempo presente.

De toda forma, o que é possível notar nos três trabalhos é a percepção que os participantes têm das mudanças que gradativamente foram ocorrendo nos bairros em que moravam. A propósito, coincidentemente, são três bairros que tiveram grandes mudanças que foram testemunhadas pelos participantes. Posso dizer que, desse modo, as mudanças ocorridas no tempo e no espaço não passaram despercebidas por eles que, atentos, puderam acompanhar as transformações, tal como os demais moradores dos bairros: a urbanização da favela, o asfaltamento das vias e a construção das casas no Jardim das Orquídeas, a abertura do beco, a construção das casas e da escola na Vila Rosa e tantas outras citadas por Luzia, Márcio e Mário.

Mas não foram somente mudanças no aspecto físico do bairro; eles testemunharam também a partida de muitos vizinhos e a chegada de outros. Alguns que partiram eram amigos e, desse modo, o lugar em que eles viviam pareceu mais vazio até se chegar à constatação de que o bairro já não era mais o mesmo. 0 tom melancólico da saudade do passado é também um ponto em comum no relato dos participantes - às vezes me dava a 
impressão de que eles viam os amigos partindo, cada um seguindo o seu rumo, tomando o trem da vida e eles, de certa forma, parados na estação, somente observando. Eu tinha a impressão de que para Luzia, por exemplo, isso era muito claro. Ela não poderia mais deixar o trem partir, não poderia deixar passar a sua vez de embarcar e, quando surgiu a oportunidade, abandonou a condição de "encalhada' - termo que ela mesma utilizou - para ganhar o status de casada. Entre os três, era somente ela que explicitava essa expectativa, quem sabe, por vários motivos; talvez por reconhecer concretamente essa possibilidade para si e por estar mais próxima de um grupo social em que o casamento é uma condição esperada. 0 trem passou, ela embarcou e partiu deixando seu bairro para trás.

A expectativa da partida em direção ao futuro não comparece claramente no horizonte dos rapazes, mas se eu afirmasse a inexistência de uma perspectiva traçada por eles, certamente eu estaria enganado. A princípio, não me parecia claro qual era a expectativa que estabeleciam para si mesmos. Se, para Luzia, o casamento era o horizonte esperado, para Mário e Márcio o futuro parecia ainda não esboçado.

Mário não falava de grandes planos para mudança de vida em longo prazo; suas preocupações me pareceram acercar-se mais do momento presente ou a um futuro não muito distante; quem sabe a expectativa de uma viagem pouco provável de ser realizada devido à ausência de um acompanhante disponível ou, ainda, a espera do final de ano para poder presentear algumas pessoas queridas. Mas depois percebi que eu estava equivocado; havia, sim, uma expectativa muito clara para Mário: ele aguarda há muito tempo a chance de um estágio fora da oficina abrigada. Como foi visto, Mário está desde 1984 e nunca teve a oportunidade que outros já tiveram. Este parece ser o sonho de Mário, esperar pelo trem que poderá levá-lo a uma experiência tão aguardada. O seu futuro, desse modo, circunscreve-se ainda no horizonte do trabalho, mas na possibilidade de deixar o universo tão restrito da oficina abrigada. 
E o futuro para Márcio? A impressão que eu tenho é que no seu caso, o futuro acabou de acontecer. Há tantos anos na escola especial e, depois de sua saída, ainda ter que andar acompanhado por sua mãe... Mas, depois de tanta espera, enfim a sua oportunidade chegou; chegou a sua vez, chegou a sua hora e ele também partiu com o trem, num caminho sem volta porque, afinal, as conquistas são irreversíveis, não são? E ele não embarca para dentro do bairro, vai para fora em busca de companhias que não encontrou no lugar em que mora.

Desse modo, se o tempo passou no bairro e o modificou, certamente passou para eles que também se transformaram. Tornaram-se pessoas mais independentes do que eram no passado e com mais possibilidades de contato social. Talvez Mário e Márcio permaneçam ainda bastante tempo dentro de suas casas, mas agora, pelo menos, podem sair e retornar sem medo de esperar pela varinha de amora. Eles não precisam fugir mais, como faziam quando eram crianças. A bicicleta, velho sonho de infância, foi esquecida nos porões, mas ficou ainda muito viva nas lembranças. Era a bicicleta que Ihes proporcionava os breves momentos de liberdade, de corrida pelo bairro, mas que provavelmente deixava as famílias em desespero. Histórias tão distintas, mas com pontos tão semelhantes.

Mas não é somente a bicicleta que Mário e Márcio têm em comum em suas histórias. Eles têm também a experiência da perda de uma pessoa da família, assim como as recordações que guardam do tempo passado em que compartilhavam ainda da companhia dos que se foram: o bolo de aniversário, a árvore de Natal com luzinhas, a peregrinação pelas igrejas são recordações que Mário guarda de sua mãe; Márcio, por sua vez, recorda da época em que ia pescar com seu pai na represa, um homem trabalhador, mas consumido pela bebida.

Mário e Márcio falaram pouco sobre a vivência da deficiência na infância. Márcio relatou brevemente que fez uma cirurgia no braço e que depois dela piorou bastante a sua movimentação, pois recorda que, quando era pequeno, andava de bicicleta utilizando ambas as mãos. Mário não falou 
sobre as suas convulsões na infância, referindo-se a elas somente no momento presente, motivo pelo qual necessita tomar medicação.

\section{A história reconstruída com os outros: encontros e desencontros}

Luzia não teve o mesmo privilégio que Mário e Márcio tiveram de poder ouvir um pouco da própria história recordada e contada por outras pessoas. Certamente, não foram todas as coisas que gostaram de ver lembradas, pois já era para terem sido esquecidas. Quem mandou a mãe de Márcio lembrar e contar que ele teve que arder o castigo da pimenta por causa de sua língua solta?

A recordação ocorre sempre de certo ponto de vista e, por isso, pode não coincidir com a perspectiva de outrem. Márcio, por exemplo, discordava dos relatos de sua mãe e de sua vizinha quando diziam que na sua infância ele ficava mais dentro de casa. A imagem que guarda de si e de seu passado é que era um menino travesso e "rueiro". Certa vez, contou também que ia ao brejo colher capim para as galinhas e foi desmentido por sua mãe quando assistíamos à sua gravação. Em outro momento, resolveu por si mesmo fazer uma retificação de seu depoimento, dizendo que, na verdade, ele não jogava bola no campo, mas andava de bicicleta.

Durante a pesquisa não tive intenção de conferir ou averiguar a veracidade dos relatos em nenhum dos casos, pois, o que me importava era conhecer e compreender a história pela perspectiva dos narradores. Nesse sentido, o que estava valendo era o relato de Márcio, mas depois da contestação de um fato por sua mãe, passei a me perguntar o motivo que 0 teria levado a "inventar" ou "florear" um pouco a história.

Rego (2003, p.80) no capítulo em que discute as narrativas autobiográficas em seu livro "Memórias de escola", cita Lahire (1997) quando este afirma que o indivíduo pode, portanto, "subestimar ou superestimar aspectos que considera mais ou menos legítimos na sua trajetória, traço que 
ilustra a natureza construtiva envolvida no ato de narrar uma vida, fruto das complexas experiências do sujeito".

Em outro trecho, mais adiante, a autora observa que a narrativa autobiográfica decorre da reconstrução de suas experiências, mas também "do tipo de interação estabelecida com o entrevistador, que influenciará até mesmo no tipo de informação que o sujeito entrevistado julga como importantes de serem abordadas (...)" (Rego, 2003, p.82).

Não cabe aqui dizer o que foi subestimado, superestimado, ressaltado ou inventado, mas apenas perguntar sobre quais teriam sido os seus motivos. Que imagem queria mostrar de si, para si e para os outros que, no caso, inclui a mim também. E aqui arrisco uma inferência.

Ao dizer que era um garoto rueiro, travesso, talvez ele quisesse mostrar a imagem de um menino que queria ser ao contrário do que tinha que ser: obediente, submisso, mesmo que contrariado e sob a ameaça da vara de amora.

É possível que Márcio quisesse criar uma imagem positiva de si, como alguém prestativo e não somente como uma pessoa dependente quando inventa que ia buscar capim para as galinhas ou, ainda, a imagem de um rapaz sociável que jogava bola. São imagens que representam um padrão de normalidade, um tipo ideal, em contraposição à condição desviante vivida por Márcio. É, desse modo, uma tentativa de aproximação do modo como ele gostaria que tivesse sido e não necessariamente do modo como foi. E aqui não está sendo colocado como parâmetro somente a verdade contada pelos outros, mas, de certa forma, admitida por ele mesmo, pelo menos em algumas passagens em que ele se retratou. E se não tivesse havido a contestação de sua mãe, teria ele mantido a sua versão? Será que se retratou somente em obediência à autoridade? É difícil saber.

De toda forma, penso que os relatos feitos pelas outras pessoas não têm somente a conotação negativa de desmentir ou atenuar os exageros cometidos pelo narrador. Eles representam principalmente a possibilidade da reconstrução conjunta. 
Mário, ao conversar com sua amiga Gisa e com o chaveiro, teve a oportunidade de recordar de passagens e detalhes que talvez não recordasse sozinho, assim como pode contribuir também para o resgate daquilo que havia sido esquecido ou era desconhecido pelos seus vizinhos. Nesse sentido, ele não era somente um ouvinte, mas um participante.

\section{A memória compartilhada e a inclusão social}

A história do bairro e a história de cada um dos participantes se entrelaça numa trama que, ao tentar separar os fios, corro o risco de desfazer o tecido e as figuras nele presentes. Foi essa a impressão que eu tive ao trabalhar sobre as histórias contadas pelos participantes. Desse modo, vejo que a história de cada um é parte da história do bairro, assim como a história do bairro, por sua vez, é parte da história de cada um.

Schimidt (1994, p.97) em seu artigo "O passado, o mundo do outro e o outro mundo: tradição oral e memória coletiva" discute como a memória coletiva do grupo estudado é representado por uma das integrantes desse grupo que desempenha o papel de porta-voz, pois "seu pensamento sintetiza visões compartilhadas por aqueles que a cercam" (1994, p.97). A autora cita ainda Halbwachs apontando que para ele "cada memória individual é um ponto de vista sobre a memória coletiva, mas um ponto de vista que revela a complexidade das influências sociais e da combinação de onde saiu" (1994, p.97).

A partir do que aponta a autora e das reflexões que venho fazendo acerca dos trabalhos dos participantes, penso que existe uma relação entre a memória coletiva e a inclusão social. Quero dizer que, na medida em que um indivíduo pode compartilhar das lembranças, representações, crenças de um determinado grupo social ou comunidade, significa que ele está inserido, incluído nesse grupo, significa que dele faz parte. Nesse sentido, compartilhar da memória coletiva é um indício da inclusão do indivíduo em seu grupo. 
A inclusão não se dá por mera inserção do indivíduo em determinado grupo social ou pelo simples fato de compartilhar com outros o mesmo espaço físico. A inclusão, em seu sentido pleno, é muito mais do que isso, obviamente se estivermos tendo como referência algo diferente de uma inclusão marginal.

Lígia Amaral (1995) discute essa questão em um capítulo especialmente dedicado à integração social ${ }^{4}$. A autora, primeiramente, apresenta duas maneiras possíveis de se compreender o significado da palavra integrar: "tornar inteiro", "completar" e também "estar junto", "não separar" e "não segregar" (Amaral, 1995, p.101). Ela opta por discutir o segundo sentido apontado, mas não deixa de salientar o cuidado necessário com o primeiro sentido, pois, ao se entender a deficiência como uma falta e a integração como uma tentativa de completá-la, torná-la inteira, pode-se correr o risco de desvalorizar a diferença e querer que o "deficiente se torne "igual" ao grupo de referência" (1995, p.101). Pode revelar, ainda, o desejo de que a diferença seja eliminada pela dificuldade de se lidar com a diversidade.

Ao tratar do segundo sentido, Lígia Amaral aponta para a necessidade da eliminação das barreiras (entenda-se, não somente as barreiras físicas, arquitetônicas como também econômicas, políticas, morais, culturais, mas principalmente as barreiras atitudinais como os preconceitos, estereótipos e estigmas lançados sobre as pessoas com deficiência) e à "equiparação de oportunidades" de acesso.

A autora aponta e discute também, a partir de suas referências teóricas, quatro diferentes níveis de integração: físico, funcional e comunitário/societal. Em relação ao primeiro nível, Lígia Amaral atenta para a profunda ambigüidade presente nele, pois a proximidade pode contribuir tanto para a minimização do preconceito como, pode também,

\footnotetext{
${ }^{4}$ A autora não faz aqui uma diferenciação entre os termos "inclusão" e "integração". Em palestra proferida no "I Ciclo de debates multiprofissionais sobre a inclusão da pessoa com deficiência" (Amaral, 1998c), publicado na íntegra na revista "Distúrbios do desenvolvimento", v.7, n39, 1998, a autora justifica o motivo pelo qual discorda da diferenciação entre os termos.
} 
contrariamente, fortalecer o estigma, se não existir outras intervenções além da mera aproximação física (1995, p.103)

Crochík (2001) em seu artigo intitulado "Teoria Crítica da Sociedade e Estudos sobre o preconceito" discute a "hipótese de contato", apontando justamente a possibilidade da ocorrência dessa ambigüidade no contato entre diferentes indivíduos ou grupos.

Na primeira parte de seu trabalho Crochík retoma a discussão sobre os estudos da personalidade autoritária, revendo inclusive as críticas feitas a esse estudo e, na segunda parte, o autor dá continuidade à sua reflexão enfocando a hipótese de contato.

0 autor mostra que na literatura portuguesa da década de noventa 0 preconceito contra migrantes e deficientes predominava como temas. Cita o estudo de Monteiro et al. (1999) em que os pesquisadores comparam atitudes de crianças sem deficiência em relação a crianças com deficiência em duas situações: primeiro, em escolas que não aceitam deficientes e, segundo, em escolas que aceitam deficientes. Contrariando o senso comum, a pesquisa mostra como resultado que as crianças que não convivem com colegas deficientes no cotidiano escolar apresentam uma avaliação mais positiva do deficiente do que aquelas crianças que estudam em escola mistas. Desse modo, "as autoras consideraram que o simples contato com crianças deficientes, sem nenhum apoio institucional, aumenta as atitudes contrárias aos deficientes" (Crochík, 2001, pp.83-82), reforçando, desse modo, o alerta apontado por Lígia Amaral.

Um pouco mais adiante Crochík apresenta o que é entendido como a hipótese de contato:

A hipótese do contato surge, segundo Monteiro (1996), do pressuposto da atração interpessoal, ou seja, o contato entre membros de grupos distintos permitiria verificar as semelhanças existentes quanto aos valores, idéias, emoções, permitindo reelaborar a percepção inicial de diferenças. Essa hipótese implica que o preconceito é um julgamento estabelecido na ausência de experiência, o que fortalece a tese de Horkheimer e Adorno 
(1985), a qual sustenta que o anti-semitismo não decorre do contato do anti-semita com o judeu e que esse é um objeto, de certa forma, imaginário para o preconceituoso, criado sem nenhuma base na realidade. Esses autores, no entanto, fornecem dados para evidenciar que esse fenômeno pode ser também ilusório, ou seja, pode consistir numa deformação da percepção do objeto: características adquiridas por motivos sociais seriam naturalizadas e universalizadas para todos os indivíduos que pertencem a determinado grupo, o que explicaria, em parte, as concepções dos nazistas de raça e de anti-raça. (2001, p.83)

Dando prosseguimento a sua discussão Crochik (2001,p.89) apresenta outros estudos indicando que:

(...) o contato entre grupos conflitantes tende a ser profícuo, desde que garantidas algumas condições: cooperação, amizade, ilustração, um clima cultural geral adequado (...)

Todavia, o autor aponta que tais estudos, ao enfatizarem as condições circunstanciais, tais como essas acima citadas, deixam de lado a crítica da estrutura social e, desse modo, nas palavras do autor "impede que sejam percebidos e combatidos os determinantes sociais e psíquicos da violência" (Crochík, 2001, p.95). Ele não pretende com sua crítica retirar a importância dos estudos sobre a hipótese de contato, mas enfatiza a importância em mostrar seus limites, pois:

(...) sem a percepção desses limites, como foi dito, correm o risco de fortalecer o que estão combatendo, uma vez que os obstáculos a ser enfrentados, por não serem visíveis, continuam a alimentar as tentativas que combatem os seus frutos, mas não esses obstáculos. (Crochík, 2001, p.96).

Sem deixar de considerar a crítica social, necessária para a compreensão e o combate efetivo ao problema da violência, o que me 
chama atenção é a possibilidade de uma convivência frutífera entre grupos ou indivíduos diferenciados quando existem condições favorecedoras para isso, ainda que, tal como aponta o autor, essa convivência possa ser fragilizada e não duradoura em vista do contexto social e histórico em que ela ocorre. Uma dessas condições, segundo Allport, citado por Crochík, é a predominância das relações de cooperação, ao invés das relações de competição.

Lígia Amaral aponta uma terceira possibilidade decorrente do contato com o diferente/deficiente, além das duas já discutidas. Ela aponta para a possibilidade do contato despertar a curiosidade que pode levar ao "desejo de conhecer mais e melhor" o outro (1995, p.105). Desse modo, a autora não deixa de apontar para o aspecto positivo do contato, apesar da ambigüidade presente, pois entende que o "tornar visível" é o primeiro e necessário passo em direção à integração. Mas, é importante ressaltar, o contato é apenas o primeiro passo, não devendo se limitar a ele!

Nesse sentido, Lígia Amaral apresenta o segundo nível de integração referindo-se à redução da distância "funcional", ou seja, "as pessoas podem e devem ter uma atividade em comum" (1995, p.105), ainda que utilizem estratégias e equipamentos diferenciados e desenvolvendo essas atividades em ritmos diferentes.

No terceiro nível, o que a autora denomina como "integração social" (1995, p.106), espera-se que ocorra a redução da distância interpessoal em vista da efetivação da comunicação entre as pessoas. Desse modo, espera-se também que a interação reduza o eventual sentimento de isolamento por parte da pessoa com deficiência. Todavia, alerta a autora, a simples comunicação não implica necessariamente na igualdade de oportunidades e, também, é importante observar que na comunicação estabelecida ainda pode prevalecer a verticalidade típica das relações assimétricas sustentadas pelo exercício do poder. Nesse sentido, Lígia Amaral defende a existência de uma outra forma de relação e comunicação em que predomine a horizontalidade e a reciprocidade que possibilita a troca e a mudança mútua 
entre as partes envolvidas. E este é um aspecto fundamental do encontro entre diferentes indivíduos ou grupos, isto é, a convivência verdadeira não beneficia somente uma das partes, mas todos aqueles que estiverem envolvidos. Não se trata, desse modo, de beneficiar somente 0 diferente/deficiente, mas em proporcionar a todos o crescimento promovido pela diversidade. Infelizmente 0 benefício e o crescimento mútuo proporcionado pela convivência na diversidade ainda não é tão claro a todos, principalmente para aqueles que insistem em permanecer enclausurados no conforto e na segurança do que é familiar, mas isso é compreensível, pois sabemos o quão ameaçador é o desconhecido, mas tão fascinante e enriquecedor também pode ser. $E$ isso me faz lembrar de uma música intitulada "Te guste o no", interpretada pelo cantor espanhol Serrat ${ }^{5}$ que diz o seguinte:

No sé si me gusta más de ti

lo que te diferencia de mí,

o lo que tenemos en común.

Te guste o no,

me caes bién por ambas cosas.

Lo común me reconforta,

lo distinto me estimula.

Lígia Amaral observa que essas relações não podem se limitar a "vontades" individuais, necessitando ainda um esforço coletivo. A autora aponta, então, para o quarto nível de integração referindo-se às mudanças no âmbito político e institucional, tanto na esfera pública como na privada e ações que visem eliminar os obstáculos: legislação, investimentos econômicos em serviços de reabilitação, eliminação de barreiras arquitetônicas, reciclagem profissional entre outras (1995, p.108).

As questões colocadas por Lígia Amaral a respeito da integração social da pessoa com deficiência ilumina a discussão e nos possibilita a reflexão

${ }^{5}$ A letra completa da música pode ser encontrada no site: www.jmserrat.com. 
mais profunda a respeito das condições concretas encontradas em cada situação. Não basta, portanto, estar junto. Participar significa poder escutar e compartilhar do que os outros têm a dizer, a contar, mas, sobretudo, ter o direito de falar e também ser escutado; é poder ter a chance de dar a sua contribuição, mostrar o seu ponto de vista.

Penso que a memória de um grupo ou comunidade só se torna efetivamente coletiva na medida em que as experiências individuais podem ser trocadas, rompendo, desse modo, 0 isolamento de seus membros. Somente as trocas possibilitam, inclusive, a identificação do que é comum a todos, pois, muitas vezes as pessoas que vivem em uma mesma região podem até desconhecer que, aquilo que foi vivido individualmente é, na verdade, comum a muitas outras pessoas. Lembro-me, nesse sentido, do depoimento da mãe de Márcio, quando ela começa a constatar a transformação social e de hábitos que gradativamente vai ocorrendo em sua vida, desde a mudança para um bairro mais pobre até o falecimento de seu marido. Certamente que as histórias têm suas particularidades, mas o conhecimento partilhado pode revelar aspectos comuns, ou seja, quantos moradores daquele bairro se mudaram para lá, quando ainda nem existia a infra-estrutura básica, em função da impossibilidade de continuar morando em um bairro mais rico, tal como supostamente ocorreu com a família de Márcio? Ou, ainda, quantas pessoas se mudaram com suas famílias em busca do sonho de ter uma casa própria, ainda que em um bairro sem muitas condições? Somente a recuperação das histórias pode, nesse sentido, proporcionar a identificação dos moradores e possibilitar a consciência de uma história comunitária.

Penso que, de certo modo, Luzia, Mário e Márcio puderam ter acesso a história do bairro, pois foram testemunhas das mudanças que ocorreram; suas histórias se entrelaçam também na história de outras pessoas indicando certo nível de pertencimento e inclusão social. Todavia, tenho dúvidas ainda sobre o espaço que encontram em seus respectivos bairros para darem os seus testemunhos ou, ainda, se à palavra deles é conferida a credibilidade 
necessária para serem escutados e respeitados e se eles são considerados como pertencentes ao grupo de narradores da história coletiva assim como qualquer outro morador.

Penso ainda que um determinado grupo ou comunidade tornará sua memória mais rica, quanto mais diversificada forem as vozes que narram a sua história. E, nesse sentido, penso que pessoas como os participantes da pesquisa têm muito a contribuir. 


\section{Reflexões sobre algumas possíveis contribuições da pesquisa}

Antes de iniciar a discussão propriamente dita, gostaria de dizer que ainda não tenho convicções plenas acerca das reais contribuições que esta pesquisa pode oferecer aos diversos âmbitos, pois aquilo que foi visualizado como o resultado se coloca ainda no plano de uma exploração inicial e carece ser mais aprofundado principalmente do ponto de vista teórico. A dificuldade encontrada no aprofundamento de cada questão levantada abre, no entanto, caminhos para pesquisas futuras que podem ser desenvolvidas separadamente. Nesse sentido, poderia dizer que muitas das contribuições ainda se encontram no plano virtual e precisam ser encaminhadas. De qualquer forma, penso que todo pesquisador precisa prestar contas de seu trabalho à comunidade científica e à sociedade, visto que a atividade de pesquisa é sempre de interesse social.

Em seguida, passo então à tarefa de refletir sobre o que a pesquisa pode, até o momento, oferecer como contribuição, visto que não posso me furtar dessa responsabilidade.

Em primeiro lugar, proponho discutir quais podem ter sido os benefícios proporcionados aos participantes desta pesquisa; em seguida parto para uma reflexão sobre as repercussões possíveis para a pesquisa nas ciências humanas, e por fim, uma reflexão sobre as contribuições que podem ser geradas no âmbito das práticas educacionais que envolvem as necessidades especiais.

\section{Da parte que cabe aos participantes}

Em relação aos participantes da pesquisa, procurei realizar com cada um deles uma avaliação do processo vivido, buscando, desse modo, ouvir, também nesse momento, o que eles tinham a dizer.

De modo geral, todos eles disseram que gostaram de ter participado da pesquisa. De certa forma, posso dizer que não foi somente no final que 
isso pode ser observado, mas principalmente durante 0 processo de realização. Os participantes se mostraram bastante interessados e motivados; se inicialmente a proposta não parecia muita clara, na medida em que os encontros foram ocorrendo eles puderam, aos poucos, visualizar 0 que poderiam fazer. Penso que é necessário dizer que o mesmo ocorreu comigo, pois, na verdade, éramos todos marinheiros de primeira viagem e pudemos aprender juntos sobre o que podíamos fazer. Como exemplo, posso citar a inclusão das entrevistas e, nesse sentido, digo que Mário foi mais ousado do que eu, pois foi dele que partiu a iniciativa.

Penso que o fato do trabalho ter sido realizado em várias semanas possibilitou a aproximação e o conhecimento gradual entre o pesquisador e 0 participante, ainda que já existisse algum conhecimento anterior, mas, é importante frisar, tratava-se de um encontro em uma situação que era nova para todos, para realização de um trabalho que, por sua vez, também era desconhecido. Infelizmente, no caso de Luzia, pelo fato de ter sido 0 primeiro trabalho, ainda não vislumbrávamos todas as possibilidades da pesquisa que, vale dizer, ainda não foram totalmente exploradas.

Eu não sei dizer com segurança, ainda que tenha procurado obter deles um retorno sobre o trabalho, o que, de fato, essa experiência significou para cada um deles. Fico curioso para saber, por exemplo, se o trabalho despertou neles a vontade ou curiosidade de explorar ou conhecer mais a respeito do próprio bairro ou, ainda, se motivou o conhecimento da própria história. Durante o processo, ficava imaginando se os participantes se ocupavam durante a semana, no intervalo entre os encontros, de pensar sobre o trabalho que vinham realizando. Mas sobre isso também não posso dizer muita coisa. Todavia, no caso de Mário, por exemplo, pude perceber, somente depois de finalizadas as gravações, durante a observação e análise do material, alguns indícios de que ele sabia, de antemão, o que pretendia gravar em cada encontro. Isso demonstrava, segundo meu entendimento, que ele já se encontrava preparado, que aguardava pela realização. Um outro dado que considerei bastante significativo foi no dia em que ele, por 
iniciativa própria, solicitou que eu ligasse o gravador porque tinha algo importante a dizer e que gostaria que fosse registrado. Entendo essa atitude como uma tomada de consciência de que o registro é uma ação que preserva a experiência do esquecimento; revelando, ainda, a consciência que estava tendo sobre o que vinha realizando, fato que considero de fundamental importância.

Se por um lado essa quantidade de encontros possibilitou 0 desenvolvimento de uma relação mais positiva entre o pesquisador e 0 participante, por outro, penso que uma experiência mais prolongada poderia oferecer a oportunidade de aprofundar alguns aspectos. Um deles se refere à exploração e manejo do equipamento. Diferentemente da oficina de fotografia (Kohatsu, 1999a) ocorreu em um espaço de tempo maior (aproximadamente um semestre, apenas para coleta de dados e sem contar as etapas posteriores) e que possibilitou experimentações e explorações temáticas e técnicas diversificadas, na atual pesquisa percebo que ficamos um pouco presos à realização da proposta e deixamos pouco espaço para as experimentações. Não é preciso dizer que os objetivos e as propostas são diferentes, mas penso que deveria ter possibilitado um tempo maior para a exploração e a experimentação antes de iniciar as gravações do bairro.

De qualquer modo, vejo que tanto Mário como Márcio mostraram iniciativa em explorar os recursos disponíveis, principalmente o recurso de aproximação (zoom).

Pude notar que, Márcio, por exemplo, passou a prestar mais atenção em suas gravações à medida que eu ia apontando o cuidado com alguns aspectos como a movimentação da câmera, a necessidade da firmeza para a imagem não sair muito tremida, enquadramento etc. Esses aspectos somente puderam ser observados porque pudemos assistir as gravações em sua casa à medida que elas foram sendo realizadas. Um aspecto que considerei muito interessante é que ao começar a observar as imagens gravadas, Márcio se propôs a realizar novamente algumas gravações; essa iniciativa, a meu ver, revela a consciência a respeito de seu trabalho, mas 
que infelizmente não pode ser continuado pela finalização do prazo para a pesquisa. Por outro lado, penso que, se a experiência despertou neles 0 gosto pelo vídeo, isso deve ser considerado também como uma repercussão positiva da pesquisa.

Um aspecto importante revelado pela pesquisa e que, certamente merece destaque, é a possibilidade de pessoas com deficiência mental resgatarem a própria história. Eu não estaria sendo honesto se dissesse que a todo o momento acreditei nessa possibilidade, pois, ela não partiu como uma certeza ou como uma convicção, mas surgiu como uma descoberta. É claro que tive a preocupação de organizar as estratégias que facilitassem a emergência das reminiscências, como a própria caminhada pelo bairro - esta sim, era uma aposta -, assim como a utilização do vídeo como recurso de apoio às narrativas. Mas, apesar de ter apostado todas as fichas, havia sim a expectativa do que poderia surgir. Desse modo, foi uma surpresa e uma grande satisfação poder compartilhar dos momentos em que, durante as caminhadas pelo bairro, eles puderam recuperar pedaços de suas histórias que pareciam esquecidos ali, em alguns cantos, esquinas e ruas.

Essa experiência de recordação pelo contato com as marcas deixadas pelo passado, proporcionada pelas caminhadas no bairro, mostra-me como a memória não é algo que se encontra somente dentro de nós, ou tampouco fora, mas desperta pelo encontro entre o que está dentro e o que está fora, entre o narrador e os outros. Teria um imenso prazer em aprofundar a discussão sobre esses aspectos convidando Bérgson, Halbwachs, Benjamin, Proust e tantos outros que ainda eu não tive a oportunidade de conhecer e que certamente poderiam enriquecer e aprofundar as discussões iniciadas nesta pesquisa.

Visto que já adentrei pelas searas da discussão científica, entendo que devo dar prosseguimento por esse caminho. Gostaria apenas de partilhar aqui mais duas coisas, ambas a respeito das repercussões da pesquisa aos participantes. A primeira delas refere-se a minha preocupação com a tomada de consciência do processo pelos participantes. Não somente saber o que se 
está fazendo, mas saber que sabe; não somente poder reconstruir a própria história, mas saber o motivo e as conseqüências disso para si. Falo da tomada de consciência no sentido de uma apropriação de seu fazer. E penso que essa tomada de consciência não ocorre de maneira espontânea e individual, mas pelo diálogo e pela mediação de um interlocutor, não somente em função da condição colocada pela deficiência mental, mas por entender que esse é um processo fundamentalmente social. Reconheço que é uma questão que deve ser aprofundada apoiada nas devidas referências teóricas; aliás, esta não é uma questão recente, pois há anos, desde a época da Oficina de Fotografia, tenho como uma tarefa a ser desenvolvida. E aproveito para dizer que, baseado em minha experiência como profissional, vejo que a questão da tomada de consciência é algo que, infelizmente, não predomina nas pautas de discussão entre os profissionais que trabalham com alunos com deficiência mental. A impressão que eu tenho é que a grande preocupação ainda é com o saber fazer e não com o sentido desse fazer ao sujeito que faz, condição, na minha opinião, essencial para 0 desenvolvimento da autonomia, tão presente nos discursos educacionais.

A segunda observação que gostaria de compartilhar e, então finalizo esta parte, é sobre o tempo necessário para avaliar esta experiência, ou seja, penso que teria que haver certo distanciamento no tempo para se saber o que, de fato, ficou para cada um dos participantes. Há que se lembrar também que eles não tiveram acesso ao produto final, ou seja, o material de vídeo editado, até o momento de finalização da pesquisa. Feitas as duas observações, passo então para a discussão das contribuições para 0 campo científico.

\section{Considerações sobre as contribuições ao campo científico}

Sobre este aspecto, penso que, o mesmo que disse a respeito dos participantes, vale também para mim, ou seja, a tomada de consciência a respeito do trabalho ainda está por vir e talvez ocorra somente no diálogo 
com meus interlocutores. Tenho a impressão que serão eles que poderão dizer mais a respeito do trabalho do que eu mesmo, visto que ainda permaneço imerso nele e, assim, careço do distanciamento necessário para avaliá-lo de um modo mais rigoroso.

0 que consigo vislumbrar da distância que consigo tomar do trabalho nesse momento, é um pouco do que já disse anteriormente. Pelo fato da pesquisa apresentar esse caráter exploratório faz com que muitas janelas sejam abertas e poucas ainda possam ser fechadas.

Em relação ao método, não penso que a pesquisa traga inovações ou apresente algo que não seja conhecido. Apoiei-me em um tipo de pesquisa já conhecido na área da psicologia e da educação, ou seja, a pesquisa de tipo etnográfico, orientado também por uma postura fenomenológica no sentido de partir das próprias experiências vividas e focalizar a discussão em torno da compreensão dos fenômenos que ali se apresentavam. Obviamente que existem particularidades nesta pesquisa, assim como em qualquer outra que siga esse tipo de abordagem, mas penso que elas se encontram muito mais nas temáticas que foram levantadas do que necessariamente no método. Mas há pelo menos dois aspectos que merecem ser discutidos: o primeiro refere-se ao posicionamento do pesquisador em relação à pesquisa, mais precisamente a relação entre pesquisador e participantes; o segundo é referente ao modo como o vídeo foi utilizado como recurso na pesquisa ${ }^{1}$.

Em vista da dificuldade de encontrar resposta satisfatória para essas duas questões, elas permaneceram vivas e presentes ao longo da pesquisa, fazendo com que a todo o momento eu voltasse a refletir sobre elas.

Para esclarecimento maior a respeito da primeira questão, recorri ao texto intitulado "Pesquisa qualitativa, alteridade e comunidades interpretativas", de autoria da Professora Doutora Maria Luisa Schimidt (2003) que, aliás, foi quem me recomendou o texto.

Situando a discussão no contexto da universidade, Schmidt aponta que a democratização em seu interior passa também pelo modo como o

\footnotetext{
${ }^{1}$ Estas duas questões foram apresentadas na ocasião do Exame de Qualificação pela Professora Dra. Maria Luisa Schimidt que fez parte da banca avaliadora.
} 
conhecimento é produzido, implicando na necessidade de se repensar as maneiras de se pesquisar, na superação da hegemonia do saber científico em relação aos saberes populares e, assim, consequentemente, ter que refletir sobre o modo como o pesquisador se relaciona com os grupos pesquisados. Pensar nessa relação, por sua vez, implica em ter que se refletir também sobre as abordagens metodológicas que vem sendo utilizadas.

A autora faz uma citação do pesquisador português Boaventura de Souza Santos, a respeito da democratização da universidade, referindo-se a "constituição de comunidades de interpretação" (Schmidt, 2003, p.58). Trata-se de uma mudança no modo de produção de conhecimento em ciências humanas, visando um questionamento da formas tradicionais de pesquisa em que predominava principalmente a quantificação dos dados. Propõe, desse modo, a ênfase na qualidade e as decorrências desta como a singularização, a heterogeneidade.

A partir desses apontamentos, a autora propõe uma discussão sobre a pesquisa-participante, entendendo que este tipo de abordagem contemplaria os aspectos da ética e da política implicados na produção de conhecimento.

A pesquisa participante, como mostra a autora, implica numa mudança na postura do pesquisador, em seu olhar, pois ele não vai simplesmente a campo, mas constitui o campo com sua presença; desse modo torna-se sujeito e objeto, tal como seus interlocutores e, assim, sua subjetividade também passa a fazer parte daquilo que está sendo investigado.

O que vejo como bem interessante, mas ainda não totalmente assimilado por mim, é a idéia da pesquisa como trabalho compartilhado, implicando necessariamente na negociação entre o pesquisador e o grupo estudado. A pesquisa participante, nessa perspectiva, abre espaço para a constituição de comunidades interpretativas, "nas quais o conhecimento é resultado de um trabalho compartilhado" (Schmidt, 2003, p.63). 
A questão, o desafio, não é somente compreender estas afirmações do ponto de vista teórico, mas assimilá-las e colocá-las em prática no exercício da pesquisa.

Refletir sobre estas questões me fez perceber o quanto ainda estava presente 0 viés positivista em minhas concepções sobre pesquisa.

Ao rever todo o processo de investigação e a relação com os participantes, pude perceber que somente próximo do final é que a idéia da participação, da negociação começava a fazer sentido. Foi no momento em que pude notar a apropriação que Márcio fazia do trabalho, não mais a pesquisa do Lineu, mas passava a ser a pesquisa sobre o seu bairro, sobre a sua história.

É certamente um processo de aprendizagem, de compreender que a pesquisa não se situa num terreno ou no outro, mas em sua intersecção; trata-se, portanto, de substituir a conjunção "ou" da exclusão pela conjunção "e" de adição na concepção acerca da produção de conhecimento.

Retornando à questão sobre o meu posicionamento na pesquisa e na relação com os participantes, poderia dizer, desse modo, que não foi certamente uma posição fixa desde o início, mas uma mudança de lugares ao longo do processo, como se estivesse em busca do lugar a ser ocupado. $E$ pude perceber também que, de certo modo, esse lugar não foi definido somente por mim, mas ocorreu também em função do modo como 0 participante também se posicionava. Pude notar como nesse processo oscilava entre a predominância do pesquisador e a predominância do participante, tal como no movimento de gangorra. É preciso dizer também que a experiência da negociação foi algo novo tanto para um como para outro, mostrando como ainda estamos impregnados pela cultura da obediência e da subordinação. 


\section{Sobre os lugares ocupados pelo vídeo na pesquisa}

Em relação ao espaço ocupado pelo vídeo, penso que ocorreu o mesmo processo. Não houve um lugar definitivo e fixo.

$\mathrm{Na}$ fase que poderia denominar como coleta de dados, ou seja, o momento das gravações, certamente 0 vídeo foi de fundamental importância. Ele serviu como um recurso de apoio ao participante, tal como uma lanterna no meio da escuridão. Penso que foi muito importante também como um elemento de mediação entre o participante e seus entrevistados, algo como um argumento para estabelecer a aproximação e o contato.

Em relação à fase posterior, ou seja, do trabalho de compreensão acerca do material produzido, vejo que em determinado momento as imagens acabaram sendo colocadas em segundo plano em relação às falas. Penso que poderia ter explorado muito mais a análise e interpretação das imagens nos trabalhos de Márcio e Mário, tal como fiz em relação ao trabalho de Luzia.

Contudo, não posso deixar de apontar que, um aspecto interessante ocasionado pela presença do vídeo foi, sem dúvida, a condução dada ao trabalho de compreensão do material. Ou seja, o trabalho e o meu modo de pensar seguiram o raciocínio da análise do vídeo, isto é, foi na indagação do que estava sendo filmado que pude observar a existência dos temas. Esse raciocínio, por sua vez, foi levado pela necessidade de olhar para as filmagens já pensando no modo como seria feita a edição e a montagem dos vídeos produzidos.

No caso de Luzia, por exemplo, o levantamento dos temas gravados auxiliou na discussão acerca de seu trabalho: a sua casa, a casa em que morava, a vista panorâmica do bairro, a quadra, a igreja, as casas das pessoas conhecidas etc. Como foi dito em outras vezes, a gravação do bairro pelos participantes não partiu de um roteiro previamente elaborado, mas ocorreu de forma espontânea e, desse modo, as cenas gravadas não tinham necessariamente uma seqüência. A organização e a reunião das cenas 
decorreram da observação das gravações e dos temas ou assuntos recorrentes, revelando, desse modo, a existência de particularidades nos trabalhos, ou seja, um modo próprio de pensar o bairro e suas relações em cada um dos participantes.

Pelo que foi discutido até o momento, pode-se notar que do ponto de vista do método, a pesquisa não revela inovações significativas a não ser, talvez, pela maneira como a utilização do vídeo, ou melhor, a observação das imagens foi articulada ao trabalho de compreensão dando suporte para realização das discussões acerca dos trabalhos realizados. Desse modo, penso que a originalidade do trabalho se encontra mais no âmbito das temáticas propostas e em suas articulações. A pesquisa, de início, articula pelo menos três áreas de pesquisa: a educação especial, o estudo das deficiências e a inclusão social. Todavia, essas áreas já são tradicionalmente articuladas. O que permite uma nova articulação é a introdução da proposta de trabalho com a história de vida de pessoas com deficiência mental, a questão da memória individual e coletiva, a relação com 0 bairro/comunidade e a utilização do vídeo e das imagens como elemento articulador.

\section{Considerações sobre as contribuições ao campo educacional}

Penso que poderia apontar basicamente dois pontos em que a pesquisa pode oferecer alguma contribuição: um deles se refere à introdução ou maior exploração do uso das imagens nas atividades pedagógicas; 0 outro diz respeito a necessidade de uma reflexão mais aprofundada sobre a questão da formação dos profissionais que atuam na educação especial.

Em relação ao primeiro tema, já algum tempo venho defendendo a importância de se utilizar recursos diversificados na educação de alunos com deficiência mental, principalmente o uso dos recursos visuais. Essa utilização de imagens, figuras símbolos já vem sendo bastante difundida por meio da comunicação alternativa, bastante utilizada principalmente na comunicação 
de pessoas com paralisia cerebral e prejuízos na fala, na educação de crianças autistas pelos diferentes métodos, mas o que proponho aqui é um pouco diferente dessas propostas. 0 que venho pensando é a utilização das imagens visuais como fotografias, filmes vídeos não somente como meios de comunicação, mas, sobretudo, como meios de expressão.

A fotografia e o vídeo podem ser recursos valiosos para proporcionar aos alunos a percepção e a interpretação da realidade em que vivem. Trabalhar com esses recursos significa dar a oportunidade de se conhecer e explorar outras linguagens além da verbal, mas também uma forma de estimular seu desenvolvimento. As imagens podem estimular a linguagem verbal e dar o suporte necessário para a organização do discurso e das narrativas. Tenho visto como muitas vezes a conversa com uma pessoa com deficiente mental pode ser pouco fluente por falta de suportes necessários para que ele possa evocar informações ou organizar seu pensamento. No período em que trabalhei na escola especial tive o privilégio de presenciar cenas muito interessantes proporcionadas por atividades utilizando imagens. Nesse caso, não se tratava da produção de fotos ou vídeos, mas de um exercício de leitura e interpretação da imagem vista pelos alunos. A experiência foi muito interessante porque não se limitou à descrição das imagens, sendo estimulado também a interpretação do que estava ocorrendo na cena observada e, ainda, estimulando o aluno para entrada no plano da ficção, ou seja, incentivando a criação de histórias partindo da cena inicial.

Todavia, penso que trabalhos como esses exigem uma preparação do professor, uma fundamentação teórica, pois não podem ser realizados de modo espontaneísta e no improviso.

Durante todo o tempo em que trabalhei na escola especial procurei levar e mostrar a importância da cultura visual na educação, mas avalio que minhas tentativas foram vãs, não sendo assimiladas pelos profissionais da escola porque 0 trabalho de formação se deu de forma bastante assistemática. Mas penso que não foi somente por este aspecto. Penso também que é preciso efetivar uma mudança de cultura e mentalidade, 
provocar uma reflexão sobre o modo como os profissionais concebem a deficiência mental, infelizmente, ainda bastante atravessada pela visão organicista. E este é o segundo ponto que gostaria de abordar.

$\mathrm{Na}$ verdade esta questão já foi discutida por mim anteriormente, desse modo, farei apenas uma breve pontuação.

Em minha opinião, a visão que muitos profissionais têm da deficiência mental limita-se a compreensão da condição orgânica, enfocando principalmente os limites impostos por ela. É preciso, nesse sentido, refletir sobre as repercussões sociais ou, melhor, sobre a leitura social que é feita da deficiência, pois ela pode se constituir numa barreira ao desenvolvimento da autonomia do aluno com deficiência e, conseqüentemente, uma barreira à sua inclusão social.

É preciso, nesse sentido, um trabalho de formação dos profissionais que lidam com a questão da deficiência. Todavia, há que se rever também a concepção que se tem a respeito de formação, para que esta não se restrinja à mera transmissão de "novas" informações e possa enfatizar principalmente a reflexão e a auto-reflexao. E este é um ponto complicado porque exige que o profissional tenha disponibilidade para olhar para si mesmo. Ou seja, olhar para si mesmo e perceber como ele é afetado pela presença da deficiência. Não pretendo com isso propor uma terapia coletiva, mas insistir apenas para que a relação entre profissionais, alunos e familiares possa ser menos tecnicista, menos burocrática, menos fria e mais humana. 0 que se espera é que 0 profissional possa reconhecer no outro que com ele trabalha a humanidade que muitas vezes é deixada de lado no exercício de sua profissão. 


\section{CONSI DERAÇÕES FI NAIS}

$\mathrm{E}$, finalmente, chegou o momento do encerramento. Tão esperado, mas ao mesmo tempo difícil; a vontade de adiar o fim - tal como Sherazade em "Mil e uma noites" - e poder contar mais uma história e, ao mesmo tempo, a necessidade de colocar um ponto final, mesmo sabendo que há ainda tanto para se fazer. E novamente a presença da ambivalência. Mas é preciso finalizar uma etapa para que se possa começar outra.

Inicio, então, retomando os objetivos inicialmente propostos:

1. Proporcionar o conhecimento e a compreensão da relação que ex-alunos de escolas especiais mantêm com 0 bairro onde moram a partir da produção de um vídeo realizado pelos próprios participantes;

2. Analisar o processo de produção do vídeo em todas as suas etapas (que serão logo apresentadas).

Retomo também as cinco perguntas:

- Como se constituiu o universo social dessas pessoas (ex-alunos de uma escola especial) para além dos muros institucionais da escola?

- Será que a permanência na escola especial dificultou ao aluno o conhecimento de seu bairro e será que a saída da escola proporcionou essa aproximação?

- Como vivenciaram e ocuparam o espaço do bairro? Quais foram as experiências mais significativas? Em que período ocorreu (infância, adolescência, fase adulta)? 
- Como é para essas pessoas (ex-alunos da escola especial) morar na periferia? Será que o contexto comunitário (se existente) favoreceu de algum modo a sua socialização?

- Em que medida o vídeo auxilia no conhecimento da realidade vivida pelo participante da pesquisa?

Ao rever as perguntas norteadoras da pesquisa, vejo que elas foram sendo respondidas ao longo da pesquisa, mas farei uma breve retomada de cada ponto.

Em relação à primeira pergunta, sobre a constituição social fora do âmbito da escola especial, pudemos ver que em cada caso ocorreu de modo diferente, com maior ou menor inserção no bairro em que moram, mas que, de certa forma, a presença da escola especial ainda se fazia presente nos três casos pelos relacionamentos que mantinham com colegas desse universo social.

Em relação à segunda pergunta, sobre a permanência na escola especial e o conhecimento do bairro, vejo que também temos três exemplos bem distintos. No caso de Luzia, aparentemente a escola não influenciou muito na relação com seu bairro, pois mesmo tendo estudado em escola especial, ela conseguiu estabelecer e manter uma boa relação com o lugar em que vivia. No caso de Mário, foi notável como a saída da escola e a independência que veio a adquirir quando passou a ir sozinho para a oficina abrigada possibilitou a ele ampliar seu conhecimento no bairro, estreitar vínculos já estabelecidos e construir novos relacionamentos. No caso de Márcio, também pode ser observado que, durante o tempo em que esteve na escola especial, ele não estabeleceu vínculos significativos em seu bairro e, mesmo agora, com mais independência, ele não busca conhecimentos no bairro, mas em outros lugares onde moram seus amigos da oficina abrigada.

Sobre as vivências no bairro, pelo que contaram, ainda que alguns não tenham permanecido muito tempo na rua, as experiências que tiveram parecem que foram bastante significativas. Os relatos se situam mais no 
período da infância e, curiosamente, nenhum dos três fez menção ao período da adolescência. Infiro que isso tenha ocorrido pelo fato da adolescência ter sido justamente o período em que estiveram na escola especial.

Em relação à experiência de viver na periferia, penso que são três experiências que não podem ser generalizadas, assim como o conceito que se tem de periferia. Pelo que se pode ver, este conceito se torna vago diante da particularidade apresentada pelos bairros. Dos três bairros que pude conhecer, pude notar que a favela de Luzia era a que apresentava maior sociabilidade entre os moradores, algo que poderia ser identificado como espírito comunitário. Já nos bairros de Mário e Márcio, a impressão que tive é que as pessoas não compartilham tanto o espaço público, permanecendo maior tempo dentro de suas casas. Podem ser observados também alguns relacionamentos entre os vizinhos mais próximos, alguns jovens e crianças na rua. No bairro de Márcio constatei o que é chamado como bairrodormitório, ou seja, a maioria dos moradores permanece considerável parte do dia fora do bairro e só retorna no final do dia, período em que se pode observar um aumento significativo do movimento das pessoas na rua.

A partir do que foi observado, penso que dos três bairros, somente 0 de Luzia ofereceu mais condições de socialização. 0 aspecto curioso dessa história é que no lugar que o senso comum considera mais perigoso, ou seja, a favela é a que oferece mais condições de socialização, de condições de segurança para as crianças estarem brincando nas ruas pelo fato das pessoas ocuparem o espaço público e criarem uma rede de sociabilidade e de proteção.

Em relação à quinta pergunta, sobre 0 vídeo, penso que ela também foi respondida. De toda maneira, diria que sim, que o vídeo possibilitou 0 conhecimento da realidade vivida pelos participantes, mas o que de fato favoreceu essa aproximação foi a relação mantida entre o pesquisador e os participantes.

Retornando agora aos objetivos, avalio que a pesquisa cumpriu os objetivos propostos no sentido de possibilitar o conhecimento e a 
compreensão da relação dos participantes com os seus respectivos bairros. Todavia, volta a lembrar que não são dados definitivos, prontos, acabados, mas devem ser considerados mais como uma tentativa de aproximação e diálogo com os participantes a respeito do universo em que vivem.

Ao retomar agora todo o processo realizado na pesquisa, posso observar como ela foi se constituindo e se definindo à medida que foi sendo desenvolvida. Muitas reflexões foram provocadas pelas experiências que foram ocorrendo, assim como o próprio procedimento da pesquisa foi sendo aprimorado durante a sua execução. A cada experiência realizada com os participantes foi possível descobrir um elemento novo, uma nova possibilidade.

O contato com os três participantes, Luzia, Mário e Márcio, mostrou também como cada experiência é singular, como cada um descobriu o seu próprio modo de se relacionar com o bairro. Mostrou que, de fato, as generalizações podem ser indevidas, perigosas e preconceituosas. Todavia, apesar das singularidades e das diferenças das circunstâncias em que se deram as experiências de cada um, observo como é possível encontrar elos de identificação a partir de pequenos detalhes, como a lembrança de uma corrida de bicicleta, de uma pipa no céu, uma caminhada pela rua do bairro, um bolo de aniversário...

E agora, no final, vejo como mergulhei na história de cada um e passei a fazer parte delas e, assim, como cada um também entrou e passou a fazer parte da minha história. Histórias tão diversas e, ao mesmo tempo, tão familiares, tão distantes e tão próximas.

É isso. 


\section{REFERÊNCI AS BI BLI OGRÁFI CAS}

Abramovich, F. (Org.). (1983). O mito da infância feliz: antologia. São Paulo: Summus.

Amaral, L. A. (1987). Resgatando o passado: deficiência como figura e vida como fundo. Dissertação de Mestrado, Pontifícia Universidade Católica de São Paulo, São Paulo, 143 p.

Amaral, L. A. (1994). Pensar a diferença/deficiência. Brasília: Corde.

Amaral, L. A. (1995). Conhecendo a deficiência - em companhia de Hércules. São Paulo: Robe Editorial.

Amaral, L. A. (1997). Histórias da exclusão - e de inclusão? - na escola pública. In Educação Especial em debate. (pp.23-34). São Paulo: Casa do Psicólogo: Conselho Regional de Psicologia.

Amaral, L. A. (1998a). Deficiência, vida e arte. Tese de Livre Docência, Instituto de Psicologia, Universidade de São Paulo, São Paulo, 221p.

Amaral, L. A. (1998b). Sobre crocodilos e avestruzes: falando de diferenças físicas, preconceitos e sua superação. In J. G. Aquino (Org.) Diferenças e preconceito na escola: alternativas teóricas e práticas. (pp.11-30). São Paulo: Summus, 1998.

Amaral, L. A. (1998c). Incluir para quê? Temas sobre Desenvolvimento, 7 (39), 49-51.

Amaral, L. A. (1999). Alguns apontamentos para reflexão/discussão sobre: diferença/deficiência/necessidades educacionais especiais. Temas sobre desenvolvimento, 8 (47), 17-23.

Amaral, L. A. (2001). Formação profissional e concepção de deficiência: onde o ponto de encontro? In M. Marquezine, M. Almeida, E. Tanaka (Orgs.) Perspectivas multidisciplinares em educação especial //. (pp.03-11). Londrina: UEL.

Amaral, L. A. (2002). Diferenças, estigma e preconceito: o desafio da inclusão. In M. Oliveira; D. Souza e T. Rego. Psicologia, Educação e Temáticas da vida contemporânea, São Paulo: Moderna. 
André, M. E. D. A. (1995). Etnografia da prática escolar. Campinas: Papirus.

André, M. E. D. A. (1992). A contribuição do estudo de caso etnográfico para a reconstrução da didática.Tese de Livre Docência, Faculdade de Educação, Universidade de São Paulo, São Paulo.

Araújo, U. F. (1999). Conto de escola: a vergonha como um regulador moral. São Paulo: Moderna; Campinas: Editora da Universidade de Campinas.

Assis, M. (1990). O caso da vara. In M. Assis. Páginas Recolhidas, Rio de Janeiro: Livraria Garnier.

Assis, M. (1999). Conto de escola. Belo Horizonte: Dimensão.

Bittencourt, L. A. (1998). Algumas considerações sobre o uso da imagem fotográfica na pesquisa antropológica. In: B. Feldman-Bianco e M. Leite (Orgs.). Desafios da Imagem: fotografia, iconografia e vídeo nas ciências sociais. (pp.197-212). Campinas: Papirus.

Bosi, E. Os espaços da memória (1994). In E. Bosi. Memória e sociedade: lembranças de velhos. (pp.434-452). São Paulo: Cia das Letras.

Bueno, J. G. (1997). Práticas institucionais e exclusão social da pessoa deficiente. In Educação Especial em debate. (pp.37-54). São Paulo: Casa do Psicólogo: Conselho Regional de Psicologia.

Cardoso, F. H. (1981). Álbum memória de São Bernardo. São Bernardo do Campo: Prefeitura do Município de São Bernardo do Campo - Secretaria de Educação, Cultura e Esportes.

Cardoso, S. O. olhar viajante (do etnólogo) (1988). In A. Novaes (Org.). O olhar. (pp.347-369). São Paulo: Cia das Letras.

Castilho, J. C. (1998). História condensada da Represa Billings. Diadema: Prefeitura do Município de Diadema.

Carvalho, A. et al. (1996). Registro em vídeo na pesquisa em psicologia: reflexões a partir de relatos de experiência. Psicologia: Teoria e Pesquisa, $12(3), 261-267$.

Clemente, C. (1998). Apreciando o movimento: Uma cartografia da periferia da Zona Leste de São Paulo. Dissertação de Mestrado, Pontifícia Universidade Católica de São Paulo, São Paulo, 174p.

Collier Jr. J. (1973). Antropologia visual: a fotografia como método de pesquisa. São Paulo: EPU/Edusp. 
Cortella, M. S. (2002). Escola e o Conhecimento - fundamentos epistemológicos e políticos. São Paulo: Cortez: Instituto Paulo Freire.

Crochík, J. L. (2001). Teoria Crítica da Sociedade e estudos sobre o preconceito. Revista Psicologia Politica, 1(1), 67-99.

Crochík, J. L. (1997a). Aspectos que permitem a segregação na escola. In Educação Especial em debate. (pp.13-22). São Paulo: Casa do Psicólogo: Conselho Regional de Psicologia.

Crochík, J. L. (1997b). Preconceito: indivíduo e cultura. SP: Robe Editorial.

D'Antino, M. E. F. (1998). A máscara e o rosto da instituição especializada: marcas que o passado abriga e o presente esconde. São Paulo: Memnon.

D'Antino, M. E. F. (2001). Deficiência e a mensagem reveladora da instituição especializada: dimensões imagética e textual. Tese de Doutorado, Faculdade de Educação, Universidade de São Paulo, São Paulo, 272p.

Dubois, P. (1994). O ato fotográfico. Campinas: Papirus.

Feldman-Bianco, B. (1998). Introdução. In: B. Feldman-Bianco e M. Leite (Orgs.). Desafios da Imagem: fotografia, iconografia e vídeo nas ciências sociais. (pp.11-18). Campinas: Papirus.

Ferreira, A. B. de H. (1999). Novo Aurélio Século XXI: o dicionário da língua portuguesa. (3 ${ }^{\text {a. }}$ ed., rev. e ampl.) Rio de J aneiro: Nova Fronteira, 1999.

Ferreira, S. L. Espaço pessoal: uma necessidade dos pais de portadores de deficiência mental. Temas sobre Desenvolvimento, 8 (46), 41-47.

Forghieri, Yolanda C. (2002). Psicologia Fenomenológica: fundamentos, método e pesquisa. São Paulo: Pioneira Thomson Learning.

Freire, P. (1996). Prefácio. In G. Snyders. Alunos felizes: reflexão sobre a alegria na escola a partir de textos literários. Rio de J aneiro: Paz e Terra.

Freund, G. (1989). Fotografia e sociedade. Lisboa: Veja.

Gadotti, M. (Org.). (2002). Perspectivas atuais da educação. Porto Alegre: Artes Médicas.

Gatti, Bernardete. (1999). Algumas considerações sobre procedimentos metodológicos nas pesquisas educacionais. Eccos Revista Científica,6379. 
Giordano, B. W. (2000). (D)eficiência e trabalho: analisando suas representações. São Paulo: Annablume: Fapesp.

Góes, M. C. R. (2002). Relações entre desenvolvimento humano, deficiência e educação: contribuições da abordagem histórico-cultural. In M. K. de Oliveira, D. Souza, T. Rego (Orgs.). Psicologia, Educação e Temáticas da vida contemporânea, São Paulo: Moderna.

Gonçalves Filho, J. M. (1988). Olhar e memória. In A. Novaes (Org.). O olhar. (pp.95-124). São Paulo: Cia das Letras.

Guidi, M. A. (1991). De Altamira a Palo Alto: A busca do movimento. Tese de Livre Docência, Escola de Comunicações e Artes, Universidade de São Paulo, São Paulo.

Guirado, M. (1998). Análise do vídeo: psicologia, imagens, ações (pp.0834).In Anais do / Conpscic. 1998, São Paulo, São Paulo, CRP-06.

J oly, M.(1996). Introdução à analise da imagem. Campinas: Papirus.

Kohatsu, L. N. (1998). Emprego apoiado: uma proposta de inserção de pessoas com deficiência mental no mercado competitivo. Cadernos de Educação Especial, 11, 49-61.

Kohatsu, L. N. (1999a). Estudo sobre a expressão de alunos e ex-alunos de uma escola especial através da fotografia. Dissertação de Mestrado, Instituto de Psicologia, Universidade de São Paulo, São Paulo, 294p.

Kohatsu, L. N. (1999b). Escadarias: fotografias da periferia realizadas por jovens com deficiência mental [CD]. In Anais da 51 a . Reunião Anual da SBPC. Porto Alegre: RS, Porto Alegre: RS, PUC.

Kossoy, B. (1989) Fotografia e História. São Paulo: Ática, 1989.

Kossoy, B. (1999) Realidade e ficções na trama fotográfica. São Paulo: Ateliê Editorial.

Leite, M. L. M. (1998). Texto visual e texto verbal. In B. Feldman-Bianco e M. Leite (Orgs.). Desafios da Imagem: fotografia, iconografia e vídeo nas ciências sociais. (pp.37-49). Campinas: Papirus.

Martins, J. e Bicudo, M. A. V. (1994). A pesquisa qualitativa em psicologia: fundamentos e recursos básicos. São Paulo: Moraes.

Mello, S. (roteiro). (2002). Bernô: a terra dos ilustres batateiros [vídeo-filme]. A. Ferreira e F. Palermo, Prod., C. Zoboli, dir., São Bernardo do Campo: Decoupê Vídeo Produtora. VHS/ NTSC-SP, 1 h02 min, cor, son. 
Omote, Sadao. (1998). Famílias de deficientes: estudos relatados em dissertações e teses. Perspectivas multidisciplinares em Educação Especial. (pp.125-129). Londrina: Uel.

Patto, M. H. S. (1997). A família pobre e a escola pública: anotações sobre um desencontro. In M. H. Patto. (Org.) Introdução à Psicologia Escolar. (pp.281-296). São Paulo: Casa do Psicólogo.

Pesaro, M. E. (1997). Identidade e fotografia: reflexões sobre uma experiência junto a um grupo de pacientes psiquiátricos. Dissertação de Mestrado, Instituto de Psicologia, Universidade de São Paulo, 172p.

Ramos, Graciliano. (s.d.). Infância. Rio de Janeiro: Record.

Rawet, S. (2000). Gringuinho. In I. Moriconi. (Org.), Os cem melhores contos brasileiros do século. (pp.153-155). Rio de Janeiro: Editora Objetiva.

Reily, L. (2001). Armazém de imagens: Ensaio sobre a produção artística de pessoas com deficiência. Campinas: Papirus.

Rego, J. L. (1989). Doidinho. Rio de Janeiro: José Olympio.

Samain, E. (1998). Questões heurísticas em torno do uso das imagens nas ciências sociais. In B. Feldman-Bianco e M. Leite (Orgs.). Desafios da Imagem: fotografia, iconografia e vídeo nas ciências sociais. (51-62). Campinas: Papirus.

Sato, L. e Souza, M. P. R. (2001). Contribuindo para desvelar a complexidade do cotidiano através da pesquisa etnográfica em psicologia. Psicologia Usp, 12 (2), 29-47.

Saviani, D. (2003). Pedagogia Histórico-Crítica. Campinas: Autores Associados.

Schmidt, M. L. S. (1994). O passado, o mundo do outro e o outro mundo: tradição oral e memória coletiva. Imaginário, 2, 89-100.

Schmidt, M. L. S. (2003). Pesquisa qualitativa, alteridade e comunidades interpretativas. Imaginário, 9, 57-64.

Souza, M. P. R. (1997). As contribuições dos estudos etnográficos na compreensão do fracasso escolar no Brasil. In A. Machado e M. Souza (Org.). Psicologia escolar: em busca de novos rumos. (pp.137-151). São Paulo: Casa do Psicólogo. 
Tacca, F. C. (1990). Sapateiro: o retrato da casa - A representação da casa do operário sapateiro francano através de seu próprio olhar fotográfico. Dissertação de mestrado, Instituto de Artes, Unicamp, Campinas.

Van der Veer, R. e Valsiner, J. (2001). Vygostsky: uma síntese. São Paulo: Loyola.

Vygotsky, L. S. (1997) Obras escogidas 5. Fundamentos de defectologia. Madri: Visor.

Yaegashi, S. F. R. et. al. Alunos de classes especiais e sua família: algumas reflexões. (2001) In M. Marquezine, M. Almeida, E. Tanaka (Orgs.) Perspectivas multidisciplinares em Educação Especial //. (pp.409-413). Londrina: UEL. 